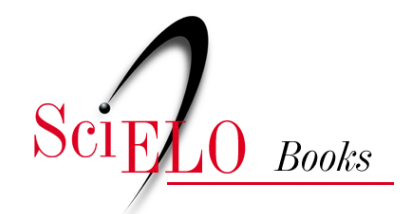

EDUFU

\title{
Pesquisa na área biomédica do planejamento à publicação
}

\author{
José Roberto Mineo \\ Deise Aparecida de Oliveira Silva \\ Mônica Camargo Sopelete \\ Geraldo Sadoyama Leal \\ Luiz Henrique Guerreiro Vidigal \\ Luís Ernesto Rodriguez Tápia \\ Maria Inês Bacchin
}

\section{SciELO Books / SciELO Livros / SciELO Libros}

MINEO, J.R., SILVA, D.A.O., SOPELETE, M.C., LEAL, G.S., VIDIGAL, L.H.G., TÁPIA, L.E.R., and BACCHIN, M.I. Pesquisa na área biomédica: do planejamento à publicação [online]. Uberlândia: EDUFU, 2005, 273 p. ISBN: 978-85-7078-523-7. https://doi.org/10.7476/9788570785237. \section{International license.}

All the contents of this work, except where otherwise noted, is licensed under a Creative Commons Attribution 4.0

Todo o conteúdo deste trabalho, exceto quando houver ressalva, é publicado sob a licença Creative Commons Atribição 4.0. 


\section{Pesquisa na Área Biomédica:}

DO PLANEJAMENTO À PUBLICAÇÃO 


\section{(5) \\ UNIVERSIDADE FEDERAL DE UBERLÂNDIA}

REITOR

Dr. Arquimedes Diógenes Ciloni

VICE-REITOR

Dr. Elmiro Santos Resende

$$
E D \cup F U
$$

EDUFU - Editora da Universidade Federal de Uberlândia

Av. João Naves de Ávila, 2121 - Campus Santa Mônica

Bloco A - Sala 1

CEP: 38400-902 - Uberlândia-MG

Telefax: (34) 3239.4293 - e-mail: livraria@ufu.br

site: www.edufu.ufu.br

DIREÇÃo EDUFU

Dra. Maria Clara Tomaz Machado

CONSELHO EDITORIAL

Dr. Carlos Roberto Ribeiro

Dra. Christina da Silva Roquette Lopreato

Dr. Décio Gatti Júnior

Dr. Domingos Alves Rade

Dr. Ernesto Sérgio Bertoldo

Dr. José Magno Queiroz Luz

Dr. José Luis Petricelli Castineira

Dr. Márcio Tannús Chaves

Dra. Maria Clara Tomaz Machado

Dr. Miguel Tanús Jorge

Dr. Roberto Rosa

Corpo Técnico Administrativo

Adelmo Gonçalves Dutra

Gerlaine Araújo Silva

Maria Amália Rocha 


\title{
Pesquisa na Área Biomédica: \\ DO PLANEJAMENTO À PUBLICAÇÃO
}

\author{
JOSÉ ROBERTO MINEO \\ DEISE APARECIDA DE OLIVEIRA SILVA \\ MÔNICA CAMARGO SOPELETE \\ GERALDO SADOYAMA LEAL \\ LUIZ HENRIQUE GUERREIRO VIDIGAL \\ LUÍS ERNESTO RODRIGUEZ TÁPIA \\ MARIA INÊS BACCHIN
}

$E D \cup F U$ 2005 
Direitos Autorais (c) 2005 Edufu

Todos os direitos reservados à EDUFU

Editora da Universidade Federal de Uberlândia.

Revisão

Ednan J. Silva

Anna Eugênia Sahione

Diagramação

André Luiz Xavier

Capa

Arlen Costa de Paula

Tiragem:

1.000 exemplares

FICHA CATALOGRÁFICA

Elaborada pelo Sistema de Bibliotecas da UFU

Setor de Catalogação e Classificação

Dados Internacionais de Catalogação-na-publicação (CIP)

P474 Pesquisa na área biomédica: do planejamento à publicação / José Roberto Mineo ... [et al.]. Uberlândia: EDUFU, 2005.

$273 p$.

ISBN 85-7078-085-0

Inclui bibliografia.

1. Pesquisa médica - Metodologia. 2. Redação técnica. I. Mineo, José Roberto. III. Título.

CDU 001.891:61 
Enquanto o mundo Lucrécio se compôs de átomos inalteráveis, o de Ovídio se compõe de qualidades, de atributos, de formas que definem a diversidade de cada coisa, cada planta, cada animal, cada pessoa; mas não passam de simples e tênues envoltórios de uma substância comum que - se uma profunda paixão a agita - pode transformar-se em algo totalmente diferente.

Calvino 


\section{SUMÁRIO}

PREFÁCIO

\section{PARTE I \\ FUNDAMENTOS DA METODOLOGIA CIENTÍFICA \\ NA ÁREA BIOMÉDICA}

\section{PLANEJAMENTO DE PROJETOS DE PESQUISA}

Luis Ernesto Rodriguez Tápia \& José Roberto Mineo

Introdução

Questões básicas na elaboração de projetos

de investigação científica

Estrutura típica de um projeto de pesquisa científica

Informações sobre a estrutura de projeto de pesquisa

para a área biomédica

Itens de uma estrutura simplificada de projeto de pesquisa .... 29

Considerações especiais ................................................... 30

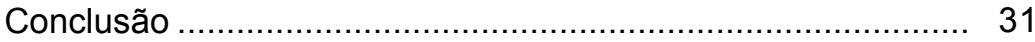

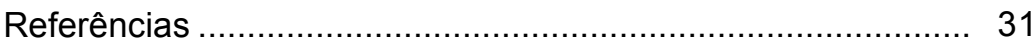

\section{LITERATURA BIOMÉDICA: ETAPAS DA PESQUISA BIBLIOGRÁFICA E ASPECTOS TÉCNICOS DA REDAÇÃO DE TRABALHO CIENTÍFICO}

Maria Inês Bacchin

Introdução

Fontes de informação ....................................................... 33

Pesquisa bibliográfica ....................................................... 34

Bases de dados automatizadas .......................................... 35

Bases de dados em ciências da saúde .............................. 35

Bases de dados nacionais .................................................. 35

Bases de dados internacionais ......................................... 36

Formas básicas de pesquisa nas bases de dados ................. 37

Localização da documentação ........................................... 38

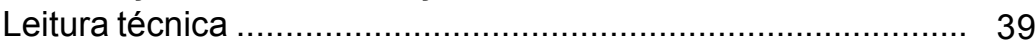

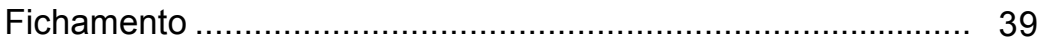

Estrutura do documento ................................................ 40

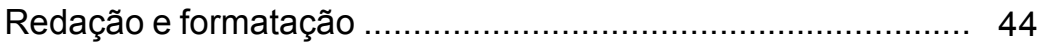

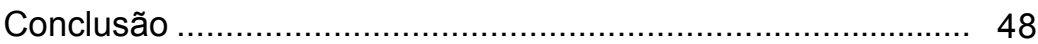

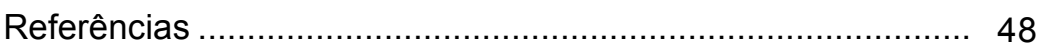

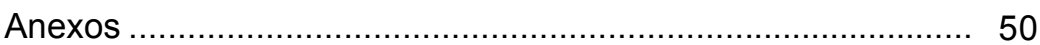




\section{3. ÉTICA EM PESQUISA NA ÁREA BIOMÉDICA}

Luiz Henrique Guerreiro Vidigal \&

Deise Aparecida de Oliveira Silva

PESQUISA EM SERES HUMANOS

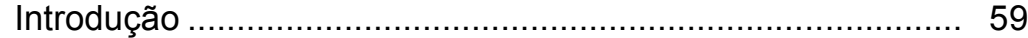

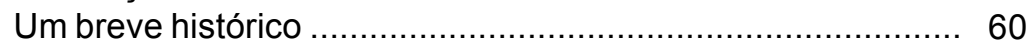

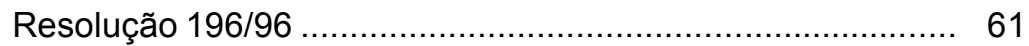

Resolução 251/97 ........................................................... 65

Pesquisa em seres humanos relacionados à ética médica ... 65

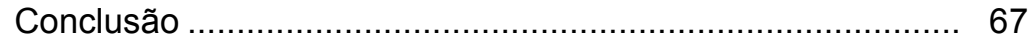

PESQUISA EM ANIMAIS

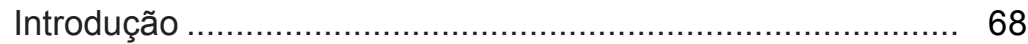

Princípios da pesquisa científica com animais ..................... 69

Regulamentações e direitos dos animais ............................ 70

Princípios éticos na experimentação animal ........................ 71

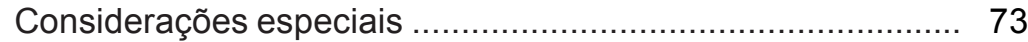

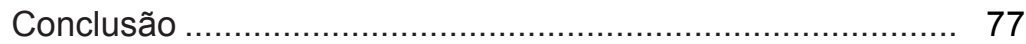

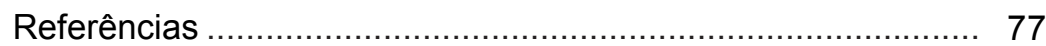

\section{MEDIDAS DE BIOSSEGURANÇA EM PESQUISA} NA ÁREA BIOMÉDICA

Introdução José Roberto Mineo

Princípios de biossegurança ................................................ 81

Métodos de biossegurança ............................................... 82

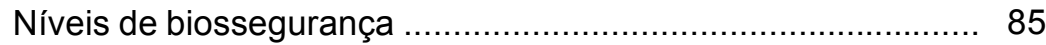

Cabines de segurança biológica ........................................ 97

Animais e principais doenças transmitidas ............................. 105

Posturas e procedimentos .................................................. 108

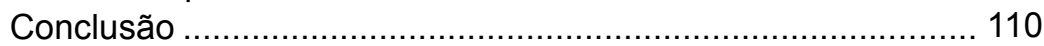

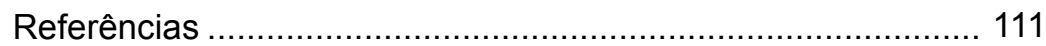

PARTE II

TIPOS DE ESTUDOS E METODOLOGIA ESTATÍSTICA

\section{CONCEITOS BÁSICOS DE EPIDEMIOLOGIA}

José Roberto Mineo \& Deise Aparecida de Oliveira Silva Introdução

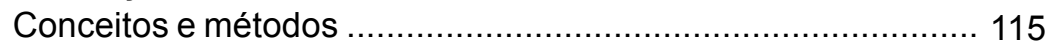

A epidemiologia e o processo saúde-doença .......................... 116 


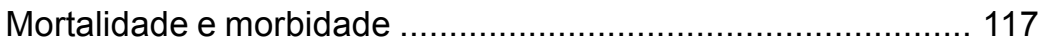

Prevalência e incidência .......................................................... 119

Epidemia, pandemia e endemia ............................................... 122

Tipos de estudos epidemiológicos ….................................... 126

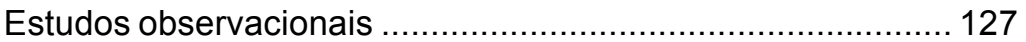

Estudos observacionais descritivos: série de casos, relato de casos ...................................................................... 127

Estudos observacionais analíticos: ecológico, seccional, caso-controle, coorte

Estudos experimentais ou intervencionais: experimentos controlados, de campo e de comunidade .............................. 130

Erros potenciais em estudos epidemiológicos ....................... 131

Erro randômico (ao acaso): erro tipo I, erro tipo II ................. 131

Erro sistemático (vício): exatidão e precisão ......................... 132

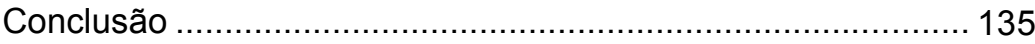

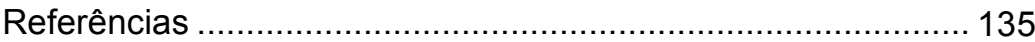

\section{CONCEITOS BÁSICOS DE BIOESTATÍSTICA}

Geraldo Sadoyama Leal, Deise Aparecida de Oliveira Silva \& Mônica Camargo Sopelete

Introdução

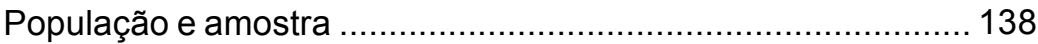

Tipos de variáveis ................................................................ 141

Medidas de tendência central: média, mediana e moda .......... 142

Medidas de dispersão: desvio padrão, erro padrão da média .. 144

Tipos de distribuição de freqüência ....................................... 148

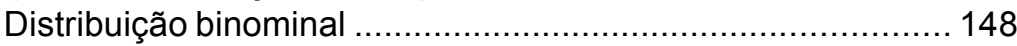

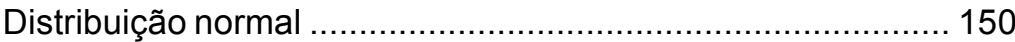

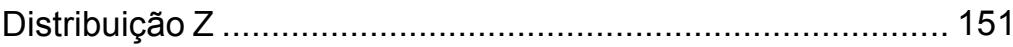

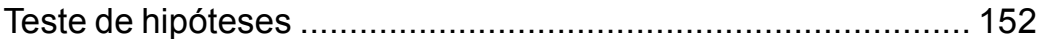

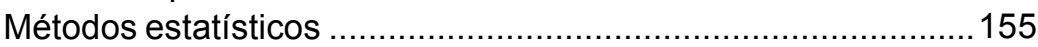

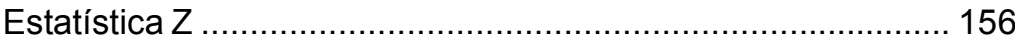

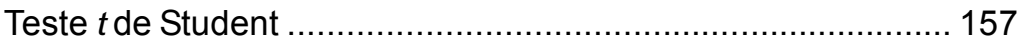

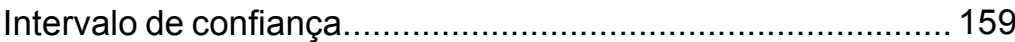

Análise de variância (ANOVA) …....................................... 161

Teste do sinal (sign test) e de McNemar ............................... 162

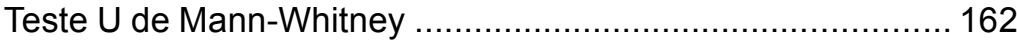

Interdependência entre duas variáveis .................................... 163

Interdependência de duas variáveis qualitativas ................... 164

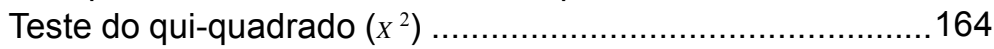

Coeficiente ou índice de associação de Yule (Q) ................ 165 
Interdependência de duas variáveis quantitativas ................. 166

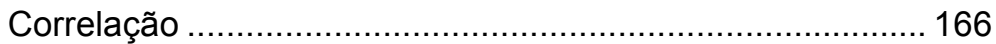

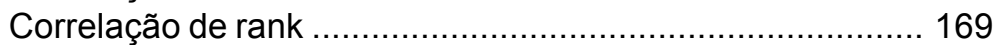

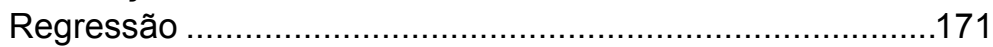

Teste exato de Fisher ......................................................... 171

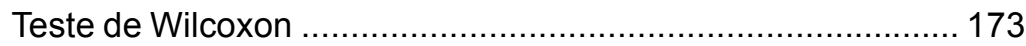

Análise de variância de Kruskal-Wallis ................................... 175

Dupla análise de variância de Friedman ............................... 177

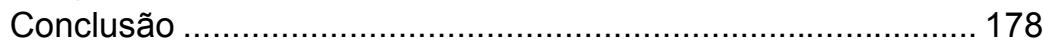

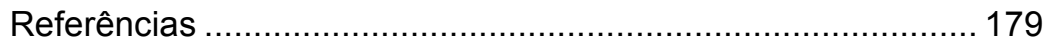

\section{PARTE III \\ MÉTODOS DE ANÁLISE EM DIFERENTES TIPOS DE ESTUDOS}

\section{MÉTODOS DE ANÁLISE EM ESTUDOS SOBRE CAUSALIDADE}

\section{Deise Aparecida de Oliveira Silva}

Introdução

Causa

Interação entre causas múltiplas 184

Fatores de risco 185

Associação causal 186

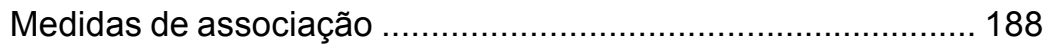

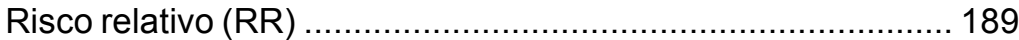

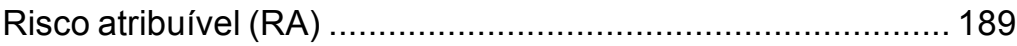

Razão de chances (OR: Odds Ratio) ................................... 190

Controle das variáveis interferentes ....................................... 194

Variáveis de confundimento (sem interação) ......................... 194

Variáveis modificadoras de efeito (sem confundimento) ....... 195

Variáveis de confundimento e modificadoras de efeito ........... 197

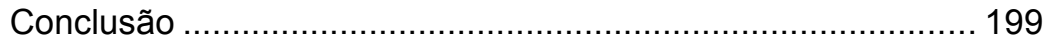

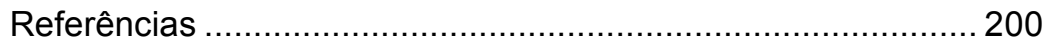

\section{MÉTODOS DE ANÁLISE EM ESTUDOS SOBRE} DIAGNÓSTICO

Mônica Camargo Sopelete

Introdução

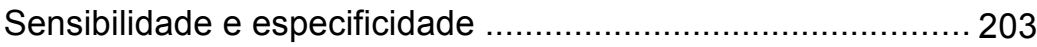

Probabilidade do pré-teste ou probabilidade de ocorrência .... 206 
Valor preditivo positivo e valor preditivo negativo .................... 206

Medidas da eficiência de um teste laboratorial ....................... 210

Teste diagnóstico: interpretação clínica e laboratorial dos

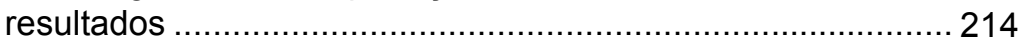

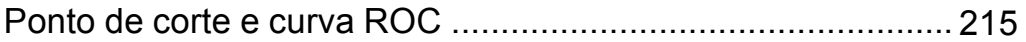

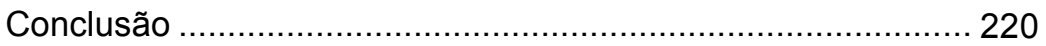

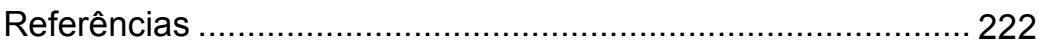

\section{MÉTODOS DE ANÁLISE EM ESTUDOS SOBRE} PROGNÓSTICO

Luiz Henrique Guerreiro Vidigal \& Deise Aparecida de Oliveira Silva

Introdução 225

História natural da doença versus curso clínico ....................... 225

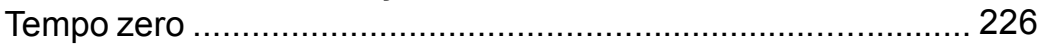

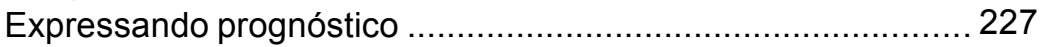

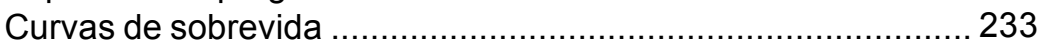

Análise de sobrevida (Kaplan-Meir) .................................... 235

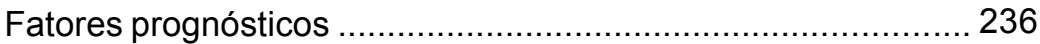

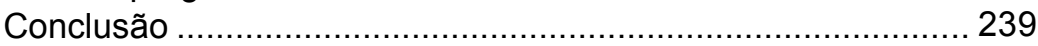

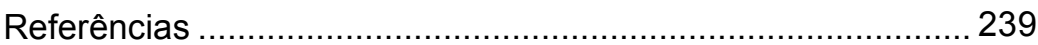

\section{MÉTODOS DE ANÁLISE EM ESTUDOS SOBRE} TERAPÊUTICA

Luiz Henrique Guerreiro Vidigal

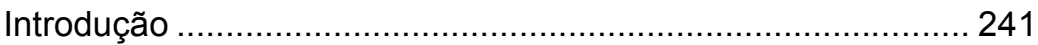

Eficácia versus efetividade ................................................... 241

Estabelecendo efeitos de um tratamento ............................... 242

Estudos não-comparativos ................................................... 243

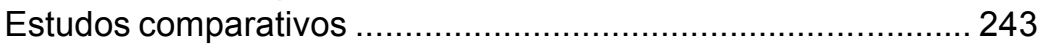

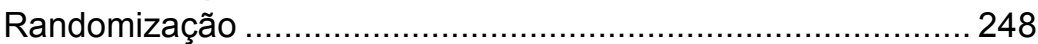

Aspectos essenciais em estudos experimentais .....................2 250

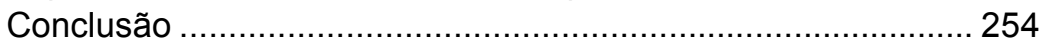

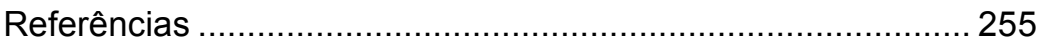

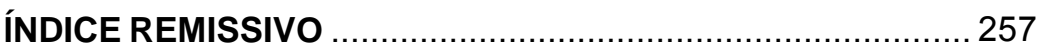

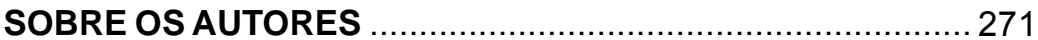




\section{PREFÁCIO}

A produção científica na área biomédica tem aumentado significativamente nos últimos anos, resultado do esforço de vários grupos de pesquisa vinculados ou não a programas de pós-graduação. A obtenção de financiamento à pesquisa, bem como a publicação dos resultados dessas pesquisas são questões vitais para o sucesso do pesquisador.

Em todo o mundo, e especialmente nos países em desenvolvimento como o Brasil, a demanda supera em muito o montante de recursos disponíveis, sendo financiados aqueles projetos cuja fundamentação e estrutura seguem padrões rigorosos de qualidade. O conhecimento sobre o planejamento e a análise de modelos experimentais torna-se então indispensável para a elaboração de hipóteses consistentes e de metodologias adequadas para que estas hipóteses sejam testadas.

É neste contexto que "Pesquisa na área biomédica: do planejamento à publicação" traz valorosa contribuição aos pesquisadores, discutindo seqüencialmente e de maneira clara e didática a metodologia científica, desde a formulação da hipótese à análise dos resultados em diferentes tipos de estudos, passando pelas orientações sobre pesquisa bibliográfica, questões éticas e medidas de biossegurança.

Este livro, tenho certeza, tornar-se-á uma ferramenta preciosa aos pesquisadores e estudantes de graduação e pósgraduação, auxiliando no planejamento e elaboração de projetos de pesquisa coerentes, facilitando a submissão às agências de fomento e a posterior redação dos trabalhos para publicação em revistas de alta qualidade, requisitos cada vez mais importantes e salutares no ambiente acadêmico, gerador de conhecimento e massa crítica para o progresso da ciência.

Profa. Dra. Janethe D. O. Pena Professora Adjunta de Imunologia e coordenadora do

Programa de Pós-Graduação em Imunologia

e Parasitologia Aplicadas

Universidade Federal de Uberlândia 


\section{PARTE I}

FUNDAMENTOS DA METODOLOGIA CIENTÍFICA

NA ÁREA BIOMÉDICA 
1.

\title{
PLANEJAMENTO DE PROJETOS DE PESQUISA
}

\author{
Luis Ernesto Rodriguez Tápia \\ José Roberto Mineo
}

\section{INTRODUÇÃO}

Este capítulo centra-se no processo cognitivo da formulação de projetos de investigação científica, visando facilitar a atividade criativa no seu estado de nascimento. Processo cognitivo é aqui entendido como a dinâmica que envolve: (1) a intuição sobre objetos ou fenômenos particulares e (2) a compreensão conceitual de características comuns de tais objetos ou fenômenos.

Serão focalizadas as etapas necessárias à formulação de projetos de investigação científica - cujos resultados são divulgados em forma de produção bibliográfica, como artigos científicos em periódicos especializados, dissertações e teses. Agrupam-se questões básicas prévias na formulação de um projeto, propondose uma estrutura de projeto típica e uma simplificada, onde são descritos os itens principais no contexto da cultura científica.

\section{QUESTÕES BÁSICAS NA ELABORAÇÃO DE PROJETOS DE INVESTIGAÇÃO CIENTÍFICA}

A tarefa inicial na formulação de projetos de investigação científica é responder a uma série de questões elementares prévias sobre o assunto ou objeto de estudo, as quais permitirão que se veja antecipadamente todo o conjunto das incumbências do projeto. Naturalmente, tais questões exigem respostas detalhadas.

Mas é preciso estar ciente de que o projeto de pesquisa integra um conjunto de ações que levam ao planejamento de atividades de pesquisa; e também que este é a primeira das três partes da produção do conhecimento, as quais incluem ainda execução e divulgação.

Questões básicas a serem formuladas durante a elaboração de projetos de pesquisa podem ser representadas no agrupamento do Quadro 1.1, a seguir. 
1) Qual o assunto do estudo? Qual o objetivo? Por que o estudo é necessário? O que a literatura científica diz a respeito?

2) Qual o problema específico do estudo? Qual a resposta?

3) Qual a base teórica do estudo?

4) Qual a metodologia? Qual o material de pesquisa, instrumentos e procedimentos?

5) Qual a base empírica ou evidências do estudo?

6) Qual a conclusão a que se pretende chegar?

QuADro 1.1 - Questões básicas a serem formuladas durante a elaboração de projeto de investigação científica

A idéia para se desenvolver um projeto de pesquisa resulta de um processo criativo que começa na dúvida e segue até a formulação de hipóteses, e cujos elementos fundamentais são a $c u$ riosidade, a iniciativa, a disposição e o raciocínio lógico. A dúvida surge da observação curiosa do mundo, onde um fato que desconhecemos nos leva a questioná-lo. Assim, tem início o desenvolvimento criativo dessa idéia, em que a reflexão motivada pela dúvida gera uma pergunta e elabora hipóteses para explicá-la.

Busca-se, então, a resposta para a pergunta na literatura, de forma a se verificar a veracidade de tais hipóteses. Nesse ponto pode haver dois caminhos: a) caso já exista resposta satisfatória, a curiosidade estará satisfeita; b) se não, a curiosidade poderá ser o início do desenvolvimento de um projeto de pesquisa. Convém enfatizar a necessidade de se buscar uma resposta satisfatória: às vezes, a resposta até já existe, mas não satisfaz o pesquisador; ele então realizará uma pesquisa, que poderá refutar ou confirmar tal resposta.

A pergunta formulada a partir da dúvida deve ser clara, única e precisa, de maneira que, ao lê-la, o autor seja capaz de saber exatamente aonde quer chegar. Todavia, na prática, o início de um projeto de pesquisa nem sempre segue essas etapas. Basicamente, existem duas formas de viabilizar esta intenção:

1. você quer fazer uma pesquisa e simplesmente procura alguém com uma idéia definida e disposto a cedê-la para que você a desenvolva - esse alguém é aquele ou aquela que orientará o trabalho; tal situação é comum em centros de pesquisa e universidades, onde estudantes procuram os professores para desenvolver projetos de pesquisa, seja em busca de aprendizado sobre o assunto e o método científico ou a fim de enriquecer o currículo com algum trabalho de natureza científica;

2. ao ler artigos científicos originais, os autores, no fim da discussão, orientam um caminho a ser seguido naquele 
tema, e este poderá resultar em uma idéia relevante e exeqüível. Dessa maneira, pode-se depreender que a formulação da pergunta é uma etapa fundamental, pois define e delimita o problema a ser estudado, fornecendo ao pesquisador o elemento principal para estabelecer o objetivo da pesquisa.

Processo de construção do saber (aprendizagem), a pesquisa tem como metas principais gerar conhecimento e/ou corroborálo/refutá-lo. Em essência, a aprendizagem é tanto do pesquisador quanto da sociedade em que a pesquisa se desenvolve. Quem a realiza pode, num nível mais elementar, aprender as bases do método científico e, num nível mais avançado, aprender refinamentos técnicos de métodos já conhecidos. A sociedade e a comunidade beneficiam-se com o uso do novo conhecimento gerado para o bem dos indivíduos.

Para ser considerada científica, a pesquisa deve obedecer a rigores impostos pelo método científico - acima de tudo, a reprodutibilidade. Assim, muito se deve aos autores que lançaram as bases para se fazer pesquisa científica, a saber: Galileu Galilei, Francis Bacon e René Descartes, no século XVI.

Galileu Galilei (1564-1642) introduziu o método científico, ressaltava o valor da experimentação como o mais importante dos procedimentos naturais e foi o primeiro a combinar a experimentação científica com a matemática. Francis Bacon (1561-1626) estabeleceu as recomendações para se realizarem experimentos de caráter indutivo; a descoberta de fatos verdadeiros depende da observação e experimentação guiadas pelo raciocínio indutivo, pois constituem meios para se chegar à verdade. A indução científica de Bacon recomendava, ainda, a descrição pormenorizada dos fatos e a tabulação para o registro das observações feitas experimentalmente. René Descartes (1596-1650) salientou a necessidade de afastamento do subjetivismo e pregou a dúvida como meio de raciocínio. Seu maior legado foi transmitir as "quatro regras de ouro": a) dividir todos os problemas em tantas partes quantas necessárias para resolvêlas adequadamente; b) conduzir ordenadamente os pensamentos: do mais simples para o mais complicado; c) realizar periodicamente revisões cuidadosas; d) acolher como verdadeira exclusivamente a conclusão que não deixe dúvida; se houver dúvida, a conclusão deve ser rejeitada. Assim, o método de Descartes é analítico: consiste em dividir os problemas e buscar uma ordenação lógica.

Estavam, assim, lançadas as bases da ciência contemporânea: redução, metodização, experimentação, quantificação, análise e generalização.

Embora se saiba que a ciência tem como paradigma o uso 
do método científico - único e com etapas bem estabelecidas existe uma tendência (ou necessidade) atual a se classificarem as atividades de pesquisa, sobretudo se pertencentes à pesquisa básica ou à pesquisa aplicada. Pesquisa básica pode ser definida como o trabalho teórico ou experimental empreendido para se chegar a novos conhecimentos sobre os fundamentos subjacentes aos fatos observáveis, sem finalidade de aplicação específica ou sem propósito prático imediato. Pesquisa aplicada, ou tecnológica, refere-se ao estudo empreendido para se obterem novos conhecimentos, que serão dirigidos a um objetivo prático ou à aplicação concreta.

No Brasil, a Constituição Federal prevê que o "Estado promoverá e incentivará o desenvolvimento científico, a pesquisa e a capacitação tecnológicas", em seu Artigo 218. O primeiro parágrafo menciona que "a pesquisa científica básica receberá tratamento prioritário do Estado, tendo em vista o bem público e o progresso das ciências"; o segundo estabelece que "a pesquisa tecnológica voltarse-á preponderantemente para a solução dos problemas brasileiros e para o desenvolvimento do sistema produtivo nacional e regional".

A pesquisa pressupõe diversos obstáculos durante sua execução, bem como o esmero do pesquisador para superá-los. Assim, ao final do processo pode-se enxergar nela uma utilidade futura, pois o pesquisador aprendeu o método científico, diversas técnicas e procedimentos distintos necessários à execução da pesquisa; agora está apto a desenvolver outros trabalhos na área. Se ele for oriundo de local diferente daquele onde realizou a pesquisa, uma nova linha de investigação científica pode ser aberta no local de onde ele veio.

Para a sociedade, a pesquisa respondeu a questões pendentes e dirimiu dúvidas sobre algo. Um novo conhecimento foi acrescentado ao rol dos já existentes, e a pesquisa que o gerou pode conter informações importantes no futuro. Quanto à comunidade científica, ela agora tem resposta para algo antes desconhecido - mas se vê diante de novas questões originadas na pergunta motivadora - e um novo membro dotado de conhecimento científico foi incorporado às suas fileiras; dele, novas pesquisas poderão surgir.

\section{ESTRUTURA TÍPICA DE UM PROJETO DE PESQUISA CIENTÍFICA}

A segunda tarefa na formulação de um projeto de investigação científica consiste em elaborar uma série de respostas às questões básicas apresentadas no Quadro 1.1.

O projeto é um documento que descreve os aspectos fundamentais da pesquisa: informações relativas ao sujeito, à qualificação 
dos pesquisadores e a todas as instâncias responsáveis. Os modelos demonstrados no presente capítulo constituem um conjunto de recomendações das agências de fomento, legislações brasileira e internacional e regras para publicações de pesquisas na área biomédica.

O Quadro 1.2, a seguir, mostra informações que devem constar entre os componentes de uma estrutura típica para a organização das respostas às questões básicas. Entretanto, é preciso salientar que tais itens não devem ser apresentados obrigatoriamente isolados ou mesmo constar em todos os projetos de pesquisa; em geral, as agências de fomento ou os programas de pósgraduação/iniciação científica apresentam modelos específicos com regras próprias. De qualquer forma, a estrutura apresentada no Quadro 1.2 indica prospectivamente o ordenamento das tarefas de um projeto ou estudo. Assim, a enumeração de I a VIII dos itens em maiúsculas já sugere a ordenação dos capítulos da futura dissertação ou tese; também indica os possíveis itens de um artigo científico em periódico especializado. Por sua vez, os subitens visam delinear a organização interna dos capítulos.

$\mathrm{Na}$ inclusão, exclusão e ordenação prospectiva de itens, sugere-se manter sintonia com o costume da comunidade científica da área envolvida e com a cultura da instituição avaliadora do projeto ou estudo.

\section{INFORMAÇÕES SOBRE A ESTRUTURA DE PROJETO DE PES- QUISA PARA A ÁREA BIOMÉDICA}

A seguir, são descritos itens considerados mais relevantes para projetos típicos da área biomédica - conforme o que o Quadro 1.2 apresenta.

\section{IDENTIFICAÇão}

Nesta primeira parte, apresentam-se os dados essenciais à identificação do projeto, tais como título, entidade a que se destina o projeto, instituição executora, instituição co-executora, instituição gestora, nome do pesquisador responsável ou coordenador, nome dos componentes da equipe técnica proponente, local e data.

O título deve identificar, com clareza, o assunto do estudo - caso seja necessário, um subtítulo também pode ser utilizado. Título com excesso de detalhes pode se tornar extenuante e dificultar a leitura do texto; por outro lado, título muito sucinto talvez não consiga anunciar o assunto. 


$$
\begin{aligned}
& \text { I - Identificação } \\
& \text { II - Resumo } \\
& \text { III - Descritores, palavras-chave, unitermos } \\
& \text { IV - Sumário } \\
& \text { V - Introdução } \\
& \text { 1. Contexto do projeto de pesquisa } \\
& \text { a. Explicitação do tema e revisão bibliográfica } \\
& \text { b. Formulação do problema de estudo e seu referencial } \\
& \text { teórico } \\
& \text { c. Hipóteses de trabalho / Tese de estudo }
\end{aligned}
$$
b. Formulação do problema de estudo e seu referencial teórico

2. Razões para a realização
a. Objetivos
b. Justificativas

$\mathrm{VI}$ - Plano de trabalho, metodologia e recursos materiais e financeiros

1.Tipo de estudo

2. Local

3. Amostra
a. Critérios de inclusão
b. Critérios de exclusão
c. Amostragem
d. Consentimento livre e esclarecido (se pertinente)

4. Procedimentos (intervenção, teste diagnóstico ou exposição) (se pertinente)

5. Variáveis

6. Método estatístico
a. Cálculo do tamanho da amostra
b. Análise estatística proposta

7. Etapas do projeto de pesquisa
a. Etapas necessárias
b. Cronograma físico

8. Relação do material e equipamentos necessários

9. Orçamento
a. Recursos financeiros (fontes e destinação)
b. Cronograma financeiro
c. Previsão de ressarcimento de gastos aos sujeitos da pesquisa (se pertinente)

10. Monitorização do ensaio clínico (se pertinente)

a. Medidas para a proteção ou minimização de quaisquer riscos

b. Medidas de monitorização da coleta de dados

c. Medidas de proteção à confidencialidade

d. Critérios para suspender ou encerrar a pesquisa

11. Análise dos riscos e benefícios 
12. Propriedades da informação e divulgação da pesquisa

13. Responsabilidades do pesquisador, da instituição, do promotor e do patrocinador

VII - Referências bibliográficas

VIII - Apêndices/Anexos

1. Formulário do consentimento livre e esclarecido (se pertinente)

2. Parecer da Comissão de Ética em Pesquisa da instituição proponente (se pertinente)

3. Formulários individuais e coletivos

4. Curricula Vitae dos componentes da equipe proponente

QuADro 1.2 - Estrutura típica de projeto de pesquisa científica na área biomédica

$\mathrm{Na}$ formulação de um projeto de investigação científica, sugere-se o exercício inicial de atribuir-lhe até cinco possíveis títulos, incluindo o respectivo subtítulo. O título deve dar uma visão geral do assunto em estudo; o subtítulo, delimitá-lo ou especificálo. A seguir, seleciona-se o título julgado mais adequado.

\section{Resumo}

Na formulação de um projeto, após a escolha do título, sugere-se o exercício de elaboração do resumo. A redação de um resumo prospectivo neste momento possibilita a sinopse ou visão prévia de conjunto do estudo a ser realizado. O resumo de um projeto corresponde à miniatura ou maquete de um projeto arquitetônico; então, deve-se manter sintonia entre ele e o projeto como um todo, de modo que as re-adequações realizadas no resumo sejam feitas, também, no projeto e vice-versa.

O resumo, na prática, influencia a decisão do leitor sobre a compreensão ou conveniência da leitura do texto inteiro do projeto ou do estudo. Logo, deve expor os objetivos a serem alcançados, a metodologia proposta, os resultados esperados e as conclusões presumíveis.

\section{DESCRITORES/PALAVRAS-CHAVE/UNITERMOS}

Consistem de vocábulos significativos que identificam o conteúdo do texto. Eles facilitam a elaboração do índice de assuntos para pesquisa bibliográfica/bibliométrica e, em geral, localizam-se após o resumo. A quantidade desses vocábulos varia conforme a agência receptora do projeto - em todo caso, podem ser usados entre três e seis.

Na formulação de um projeto, sugere-se o uso de palavras- 
chave em sintonia com as fontes de indexação da área de conhecimento específica do estudo (exemplos: Index Medicus/LILACS, Biological Abstracts/BIOSIS). Deve-se destacar a Lista de Descritores de Ciências da Saúde publicada pela Biblioteca Regional de Medicina (BIREME), pois isso também facilita a revisão bibliográfica.

\section{SUMÁRIO}

É a numeração das divisões, das seções e dos itens principais de um documento; inclui as partes da publicação que the sucedem - resumo, listas, texto, referências bibliográficas e anexos e não deve ser confundido com o índice, a ser visto adiante. $\mathrm{Na}$ formulação de um projeto, após a identificação das palavras-chave sugere-se o exercício da redação do sumário. Também prospectivo, ele possibilita a visão da estrutura do estudo a ser realizado. Essa visão estrutural antecipatória facilita a organização do processo cognitivo tanto da formulação quanto da realização do projeto ou estudo. As intelecções, intuições ou descobertas do pesquisador passam a ter nos itens e subitens do sumário um endereçamento prévio facilitador do processo criativo.

A ordenação de itens no Quadro 1.2, já apresentado, antevê uma estrutura de sumário; uma vez finalizado, após digitação do projeto, ele deverá incluir a enumeração progressiva das páginas relativas a cada item no texto anunciado.

\section{INTRODUÇ̃̃o}

Situa o assunto do projeto ou estudo numa área específica do conhecimento científico. Também pode incluir parte do questionamento básico do estudo, por exemplo: o assunto; o que diz a literatura científica; o objetivo; por que o estudo é necessário. Nesse formato, a introdução deveria incluir, respectivamente: revisão bibliográfica, objetivos e justificativas - descritos a seguir.

\section{EXPLICITAÇÃo DO TEMA E REVISÃo BIBLIOGRÁFICA}

Apresentam os resultados da análise da literatura científica sobre o assunto em estudo. Também podem assumir a forma de revisão bibliográfico-bibliométrica, em que mostram resultados quantitativos do estado do conhecimento na área específica do estudo. Podem incluir estatísticas de produção científica elaboradas com base em material bibliográfico consultado em dissertações, teses, livros, periódicos especializados nacionais e estrangeiros, bases de dados, dentre outros. 


\section{FormulaçÃo do PROBLEMA DE ESTUdO}

Obedece a esta questão básica: qual é o problema específico de estudo? Assume a forma de pergunta explícita sobre características essenciais de fenômenos, fatos, eventos ou variáveis, ou de relações entre estes.

Da adequada formulação da questão inicial depende o desenvolvimento ou a realização do projeto. Uma questão muito abrangente pode inviabilizar o estudo, e a imprecisão ou o excesso de detalhes pode mostrar falta de clareza ou indecisão sobre o tema. Por outro lado, é possível que uma questão pouco abrangente seja insuficiente para comunicar o que se propõe a investigar.

$\mathrm{Na}$ fase de elaboração de um projeto, sugere-se a formulação de cinco ou mais questões diretas sobre o assunto em estudo que expressem fielmente a preocupação básica do pesquisador e, em seguida, a seleção daquela julgada mais adequada. Alternativamente, a questão de um problema de estudo pode ser sobre a relação entre variáveis independentes e dependentes envolvidas.

Exemplos:

a) a variável participação de alunos em grupos operativos de ensino-aprendizagem influencia a variável processo ensino-aprendizagem?

b) a participação de técnicos de saúde em grupos operativos de apoio para profissionais influencia a variável redução do estresse institucional? Nessa fase da formulação do projeto, devem ser delineados os critérios de definição e mensuração das variáveis envolvidas.

\section{Referencial teórico}

Trata da sistematização conceitual que constitui a base de sustentação ou fundamentação teórica do estudo. Orientará, portanto, a análise do material a ser coletado quando se der o desenvolvimento do projeto de pesquisa. Durante a formulação do projeto, deve-se manter presente a importância da relação entre referencial teórico e metodologia: o primeiro implica uma visão teórica sobre o assunto ou objeto do estudo; a segunda envolve as formas de acesso a esse objeto.

Contudo, algumas instituições ou agências fomentadoras de pesquisa não costumam exigir a inclusão do item referencial teórico em estudos ou projetos. Em outros casos, bastaria alguma fundamentação teórica em item equivalente à introdução e justificativa.

Com base na fundamentação teórica expressa ou implícita, pode-se propor estratégias para a análise do material a ser considerado e/ou interpretação dos resultados a serem obtidos no estudo 
proposto. Em geral, interpreta-se o individual com base num todo já pressuposto, obtido, por sua vez, a partir do individual. Daí as relações recíprocas entre análise e síntese, indução e dedução em toda interpretação.

\section{Hipóteses de tRabalho/tese de estudo}

Consiste na resposta essencial, direta e inequívoca à questão delineada no problema de estudo e a ser verificada ou testada na realização do projeto. Tal resposta pode também assumir a forma de tese de estudo ou proposição a ser defendida/sustentada no desenvolvimento do estudo. Neste item deverá ser explicitada a transformação da hipótese de trabalho ou hipótese física em termos estatísticos de hipótese nula $\left(\mathrm{H}_{0}\right)$ e hipótese alternativa $\left(\mathrm{H}_{1}\right)$. Os aspectos técnicos relativos aos procedimentos estatísticos em trabaIhos científicos serão tratados no capítulo 6 deste livro.

\section{Objetivos}

Este item responde a esta questão básica: qual é o objetivo do estudo? Trata das finalidades, das intenções ou dos propósitos. $\mathrm{Na}$ formulação de um projeto, em vez da quantidade, sugere-se a qualidade de objetivos viáveis à sua realização. Os objetivos não devem ser confundidos com a justificativa - abordada a seguir. Exemplo de objetivos em monografia (TÁPIA, 1999, p. 9):

Este estudo visa a dois objetivos básicos: 1) sensibilizar intelectualmente os jovens profissionais sobre a importância e a viabilidade da atuação do assistente social na área da saúde mental;

2) subsidiar, teórica e conceitualmente, a prática profissional do assistente social numa orientação humanista no âmbito hospitalar psiquiátrico.

\section{JuSTIFICATIVAS}

Neste item procura-se responder a esta questão básica: por que o estudo é necessário? Expõem-se, dessa maneira, as razões favoráveis à realização do projeto, demonstrando-se a contribuição para a área do conhecimento específico, a possível utilização dos conhecimentos gerados e as relações com estudos semelhantes nacionais ou estrangeiros. Para responder à questão, torna-se útil, embora não necessário, situar-se o projeto em uma concepção de pesquisa básica ou de pesquisa aplicada, como visto anteriormente. 
É importante destacar que nas justificativas se descrevem, sempre que possível, as necessidades institucionais e/ou sociais a serem atendidas e a relação com políticas públicas oficiais na área de conhecimento do estudo a serem efetivadas ou otimizadas com a realização do projeto. Por exemplo, no título da ordem social na Constituição Federal e nas leis orgânicas estaduais e municipais têm-se disposições oficiais sobre educação, saúde, assistência social, saneamento básico, ciência e tecnologia e outros que traduzem necessidades sociais de interesse à pesquisa científica.

Nas justificativas pode-se ainda alegar escassez na literatura científica sobre o assunto em estudo, evidenciada na revisão bibliográfica.

Plano de trabalho, metodologia, Recursos materiais e financeiros

Esta parte se constitui na mais importante da elaboração de um projeto de pesquisa: nela deve-se especificar o conjunto de métodos, estratégias, técnicas necessárias à execução física do projeto e demais procedimentos a serem adotados pelo pesquisador proponente. Por serem diversos os tópicos aqui considerados, a explicitação irá variar conforme o tipo de estudo e o grau de extensão e complexidade - uma descrição detalhada da maior parte desses itens será aprese6ntada nos capítulos 3 e 4 e nas partes II e III deste livro. Também nessa parte do projeto deverão constar definição e caracterização dos seguintes indicativos: 1) tipo de estudo; 2) tipo de amostras; 3) sujeitos do estudo; 4) material de pesquisa; 5) instrumentos; 6 ) protocolos; bem como formas de análise e/ou tratamento de dados.

\section{ETAPAS DO PROJETO DE PESQUISA}

Este item indica as etapas necessárias para se alcançarem os objetivos propostos, com base nos resultados esperados observáveis ou quantificáveis na realização de um projeto. Em muitas circunstâncias, é importante se estabelecerem associações entre as metas quantificáveis e as estratégias para obtenção dessas metas.

\section{Cronograma físico}

Refere-se à seqüência temporal de execução das etapas previstas no projeto. Neste item deve ser apresentado um cronograma para cada etapa, a ser seguido no desenvolvimento do projeto de pesquisa. 


\section{Cronograma financeiro}

Trata dos custos da execução do projeto e deve considerar o ano econômico ou fiscal. Envolve formas de indexação financeira (por exemplo, ao dólar norte-americano) e obedece à nomenclatura do Sistema Integrado da Administração Financeira (SIAFI) - na aquisição de material de consumo e permanente, equipamentos, e na contratação de serviços de terceiros, etc. - e às disposições da Secretaria do Tesouro Nacional.

$O$ endereço eletrônico da CAPES, do CNPq, da FAPESP, da FAPEMIG e das demais agências nacionais/estaduais e internacionais de fomento à pesquisa devem sempre ser consultadas para obtenção de mais informações e atualizações relativas a procedimentos e exigências para se submeter projeto.

\section{Propriedades da informação E divulgação dA PESQUisa}

Um projeto de investigação científica pode gerar invenção patenteável. No Brasil, a lei 9.279, de 14/5/1996, regula direitos e obrigações relativos à propriedade industrial. No texto legal destacam-se:

Art. $8^{\circ}$. É patenteável a invenção que atenda aos requisitos de novidade, atividade inventiva e aplicação industrial;

Art. $9^{\circ}$. É patenteável como modelo de utilidade o objeto de uso prático, ou parte deste, susceptível de aplicação industrial, que apresente nova forma ou disposição, envolvendo ato inventivo, que resulte em melhoria funcional no seu uso ou em sua fabricação; Art. $10^{\circ}$. Não se considera invenção nem modelo de utilidade:

[...]

IX - o todo ou parte de seres vivos naturais e materiais biológicos encontrados na natureza, ou ainda que dela isolados, inclusive o genoma ou germoplasma de qualquer ser vivo natural e os processos biológicos naturais;

Art. 18. Não são patenteáveis:

[...]

III - o todo ou parte dos seres vivos, exceto os microorganismos transgênicos que atendam aos três requisitos de patenteabilidade - novidade, atividade inventiva e aplicação industrial - previstos no Art. $8^{\circ} \mathrm{e}$ que não sejam mera descoberta.

Parágrafo único. Para os fins desta lei, microorganis- 
mos transgênicos são microorganismos, exceto o todo ou parte de plantas ou de animais, que expressem, mediante intervenção humana direta em sua composição genética, uma característica normalmente não alcançável pela espécie em condições naturais.

\section{REFERÊNCIAS}

Lista o material bibliográfico e a literatura científica consultados durante a elaboração do projeto e a ser consultados no desenvolvimento da pesquisa. As informações e normas detalhadas e os aspectos técnico-documentais da citação bibliográfica de trabalhos científicos na área biomédica serão detalhados no capítulo 2 deste livro.

$\mathrm{Na}$ apresentação das referências, sugere-se sintonia com a cultura da instituição avaliadora do projeto. Dentre outras, têmse as normas do International Committee of Medical Journals Editors, Grupo Vancouver e da Associação Brasileira de Normas Técnicas - ABNT, disponíveis nos respectivos endereços eletrônicos <http://www.acponline.org> e <http://www.abnt.org.br>.

\section{ApÊndices/Anexos}

Em geral, incluem documentos relativos a informações complementares ou comprobatórias: tabelas, formulários, roteiros de entrevistas, questionários vazios, fórmulas de cálculo, etc. Localizam-se após o item referências.

Os apêndices contêm informações elaboradas pelo próprio autor a fim de complementar a argumentação, e os anexos contêm documentos não elaborados pelo autor do projeto.

\section{ITENS DE UMA ESTRUTURA SIMPLIFICADA DE PROJETO DE PESQUISA}

Reafirma-se aqui a idéia de que a formulação de um projeto de investigação científica exige que se responda a uma série de questões básicas prévias sobre o assunto ou objeto do estudo.

No estágio inicial da seleção de projetos, pode-se usar a mesma estrutura típica de projetos proposta no Quadro 1.2 - já apresentada. Porém, no estágio inicial, talvez possa ser exigida uma estrutura mais simplificada, mas cuja complexidade evoluiria em etapas posteriores da análise ou do desenvolvimento. As agências de fomento à pesquisa científica costumam indicar diretrizes e instruções para a seleção de projetos veiculadas no edital de cha- 
mada. Sugere-se obedecer expressamente às condições estabelecidas no edital. O Quadro 1.3, a seguir, descreve uma estrutura simplificada de projeto de pesquisa.

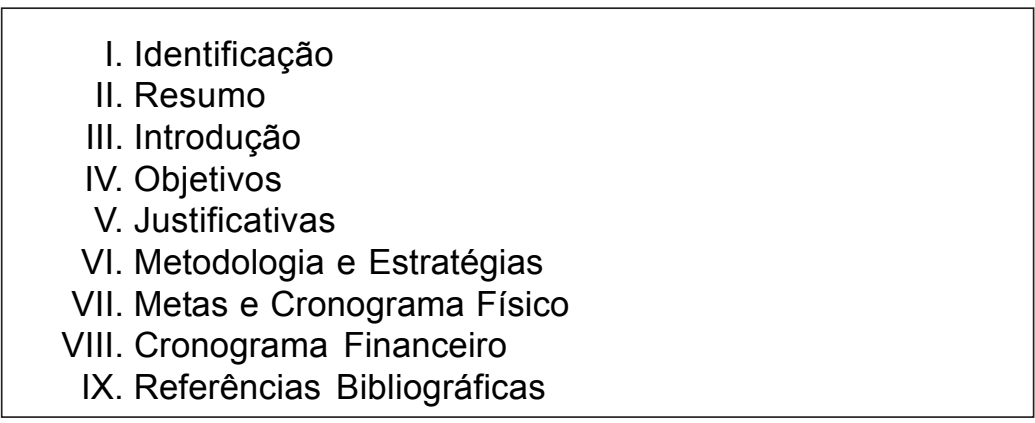

QUADRo 1.3 - Estrutura simplificada de projeto de investigação científica

\section{CONSIDERAÇÕES ESPECIAIS}

\section{1) Áreas do conhecimento}

Na terminologia do CNPq, distingue-se a hierarquia: Grandes Áreas; Áreas; Subáreas; Especialidades. Exemplos:

1) Grande Área: Ciências Biológicas; Área: Imunologia; Subárea: Imunologia Aplicada.

2) Grande Área: Ciências Biológicas; Área: Parasitologia; Subárea: Protozoologia de parasitos.

3) Grande Área: Ciências da Saúde: Área: Medicina; Subárea: Psiquiatria; Especialidade: Saúde Mental.

4) Grande Área: Ciências Sociais Aplicadas; Área: Serviço Social; Subárea: Serviço Social da Saúde.

Mais informações, no endereço eletrônico: <http:// www.cnpq.br/areas/tabconhecimento>.

\section{2) Direitos autorais}

No Brasil, a lei 9.610, de 19/02/1998, altera, atualiza e consolida a legislação sobre direitos autorais e dá outras providências. Confira também no endereço eletrônico da Biblioteca Nacional: $<$ http://www.bn.br>.

\section{3) Ética}

Como será visto no capítulo 3 deste livro, os aspectos éticos num projeto ou estudo devem ser conferidos pelas resoluções 196/96 (de 10/10/1996) e 251/97 (de 5/8/1997) do Conselho Nacional de Saúde/Ministério da Saúde. Também a Comissão Nacional 
de Ética em Pesquisa (CONEP) divulga orientações nesse sentido. Visite <http://www.datasus.gov.br>.

\section{4) Índice (Index)}

Listagem de palavras significativas indicando a localização de informações no texto. É o instrumento de recuperação de informações contidas numa publicação localizado após as referências; não deve ser confundido com sumário.

\section{5) Linha de pesquisa}

$\mathrm{Na}$ terminologia das agências financiadoras, linha de pesquisa representaria temas aglutinadores de estudos técnico-científicos fundamentados em tradição investigadora de onde se originam projetos cujos resultados guardam relação entre si.

\section{CONCLUSÃO}

Este capítulo enfocou o processo cognitivo da formulação de projetos de investigação científica, visando facilitar a atividade criativa em seu estado de nascimento. A descrição iniciou-se com a formulação de questões e respostas básicas ou essenciais e avançou na descrição de itens considerados os mais relevantes de uma estrutura típica e/ou simplificada de projeto, quando foi assinalada a terminologia básica na cultura científica.

Evidentemente, não se pretende exaurir o assunto nos limites dos temas enfocados; nessa síntese, procurou-se evidenciar o aspecto básico da natureza inacabada de um projeto ou estudo de investigação científica. E isso ilustra a essência do processo cognitivo ou da produção do conhecimento: a natureza inacabada, que possibilita o nascimento ou renascimento do projeto.

Assim, junto com questões e respostas básicas, instrumentos e métodos adequados para formulação de um projeto de investigação científica, tem-se ainda a verdade básica da sua finitude essencial - característica elementar do projeto humano.

\section{REFERÊNCIAS}

ASSOCIAÇÃO BRASILEIRA DE NORMAS TECNICAS. NBR 6022: apresentação de artigos em publicações periódicas. Rio de Janeiro, 2003. $6 p$.

BLEGER, J. Grupos operativos no ensino. In: Temas de psicologia: entrevista e grupos. São Paulo: Martins Fontes, 1999. p. 54-82. 
BRASIL. Constituição da República Federativa do Brasil. São Paulo: Rideel, 1994.

. Lei n. 9.279, de 14 maio. 1996. Regula direitos e obrigações relativos a propriedade industrial. Diário Oficial, Brasília, 15 maio 1996. Seção 1, p. 8.353-8.366.

. Lei n. 9394 de 17 dez. 1996. Estabelece as diretrizes e bases da educação nacional. Diário Oficial, Brasília, 23 dez. 1996. CASTRO, A. A. Projeto de pesquisa. In: CASTRO, A. A. (Ed.). Planejamento da pesquisa. São Paulo: AAC, 2001. Disponível em: $<$ http://www.evidencias.com/planejamento/pdf/lv4_02_projeto.pdf>. Acesso em: 10 maio 2005.

GIL, A. C. Como elaborar projetos de pesquisa. 3. ed. São Paulo: Atlas, 1995. 159p.

GOLDENBERG, S. Orientação normativa para elaboração de tese. Acta Cirúrgica Brasileira, São Paulo, n.1, p. 1-24, 1993. Suplemento. GOLDENBERG, S.; GUIMARÃES, C. A.; CASTRO, A. A. Elaboração e apresentação de comunicação científica. São Paulo, 2002. Disponível em: <http://www.metodologia.org>. Acesso em: 10 maio 2005.

JORGE, M. T.; RIBEIRO, L. A. R. Fundamentos para o conhecimento científico. São Paulo: Baliero, 1999. 106p.

PEGUIN, R. C. Concepção operativa de grupos. In: OLIVEIRA JÚNIOR, J. F. Grupos de reflexão no Brasil: grupos e educação. São Paulo: Cabral, 2002. p. 15-62.

SEVERINO, A. J. Metodologia do trabalho científico. 19. ed. São Paulo: Cortez, 1993. 252p.

SOARES, K. V. S.; CASTRO, A. A. Projeto de pesquisa para ensaios clínicos randomizados. In: ATALLAH, A. N.; CASTRO, A. A. (Eds.). Medicina baseada em evidências: fundamentos da pesquisa clínica. São Paulo: Lemos-Editorial, 1998. Disponível em: <http://www. evidencias.com/projeto.pdf>. Acesso em: 10 maio 2005.

TÁPIA, L. E. R. Elaboração de projetos de investigação científica: guia para pesquisadores em formação inicial e avançada. São Paulo: Cid, 1999. 30p. 


\title{
LITERATURA BIOMÉDICA: \\ ETAPAS DA PESQUISA BIBLIOGRÁFICA E ASPECTOS TÉCNICOS DA REDAÇÃO DE TRABALHO CIENTÍFICO
}

\author{
Maria Inês Bacchin
}

\section{INTRODUÇÃO}

Este capítulo apresenta informações técnicas sobre a elaboração de um trabalho científico - desde a pesquisa bibliográfica até a formatação final. Cada etapa será descrita passo a passo, com detalhamento e exemplificação. Serão enfocados, de início, os tipos de documentos mais usados; em seguida, os passos para a pesquisa bibliográfica, localização e recuperação dos documentos; e, por fim, descrição detalhada das partes que compõem um trabalho científico.

\section{FONTES DE INFORMAÇÃO}

Todo trabalho científico se baseia em um referencial teórico, que o sustenta, dá-Ihe credibilidade e o enriquece. Tal referencial caracteriza-se pela documentação bibliográfica, que, para a elaboração de trabalho científico, é obtida mediante uma varredura na literatura (a pesquisa bibliográfica). Esta, por sua vez, torna disponível ao interessado uma documentação caracterizada de diversas formas a que chamamos "fontes de informação", as quais são classificadas em primárias e secundárias.

\section{FONTES PRIMÁRIAS}

Contêm a informação original. Principais documentos que caracterizam as fontes primárias:

- monografias (livros, dissertações e teses): abordam assuntos específicos de forma exaustiva, com riqueza de detalhes e extensa bibliografia;

- relatórios técnicos: publicações governamentais, comerciais e de laboratórios acadêmicos com a finalidade de relatar pesquisas; 
- anais de eventos científicos: publicações resultantes de trabalhos apresentados em congressos, seminários, reuniões;

- artigos de periódicos: contêm informações atualizadas sobre novas pesquisas em áreas específicas.

\section{FonTES SECUNDÁRIAS}

Organizam a informação primária segundo um arranjo definitivo, ou servem para orientar a busca e a localização do documento primário. Principais documentos que caracterizam as fontes secundárias:

- dicionários: apresentam os significados e a etimologia das palavras; com base nessa fonte, faz-se a exploração inicial do tema;

- enciclopédias: apresentam resposta a questões simples que permitem explorar inicialmente o tema da pesquisa;

- manuais: apresentam um conjunto de informações selecionadas sobre determinado assunto;

- avanços e progressos: relatam progressos e avanços da ciência em áreas específicas;

- bases de dados: fontes de informações computadorizada que cobrem a literatura nacional e internacional; podem ser referenciais (apresentam referências bibliográficas, acompanhadas ou não de resumos); ou textuais (apresentam o texto completo dos documentos).

\section{PESQUISA BIBLIOGRÁFICA}

Antes de dar início a qualquer projeto, o pesquisador precisa conhecer bem os resultados de pesquisas anteriores. Mesmo que a idéia básica já tenha sido formulada, uma revisão de estudos já realizados o ajudará a tornar a idéia mais clara e planejar o estudo. Assim, é importante fazer uma revisão bibliográfica sobre um assunto e ler relatos de pesquisa em periódicos especializados. (COZBY, 2003, p. 37).

A obtenção de respostas precisas na busca de informações resulta de um trabalho exaustivo que exige conhecimento e habilidade nas técnicas de pesquisa. Conforme De Cesaro e Bacchin (2003), as revisões bibliográficas são realizadas em bases de dados automatizadas, que relacionam todo tipo de documentos: livros, monografias, dissertações, teses e, sobretudo, artigos de revistas. Embora a maioria dessas bases seja estrangeira, já existem portais de informações nacionais com busca e recuperação de dados bastante eficientes. 
A pesquisa em base de dados requer conhecimento dos termos relativos à pesquisa tanto em português quanto em outros idiomas; para isso faz-se necessário consultar índices e/ou descritores de assuntos, a fim de se buscar a terminologia própria dos assuntos a serem pesquisados. Conforme a base de dados pesquisada, os resultados serão apenas referenciais ou poderão vir acompanhados de resumos e/ou de textos completos.

\section{Bases de dados automatizadas}

As bibliotecas das Instituições de Ensino Superior (IES), em geral, disponibilizam, nos setores de referência e/ou através do seu endereço eletrônico, o acesso a informações de fontes bibliográficas para pesquisa científica. Mais informações podem ser obtidas no endereço eletrônico das bibliotecas da Universidade Federal de Uberlândia: <http://www.bibliotecas.ufu.br>.

\section{BASES dE dAdOS EM CIÊNCIAS dA SAÚdE}

$\mathrm{Na}$ área de ciências da saúde, existem bases de dados que cobrem a literatura nacional e internacional, com acesso público ou acesso restrito.

\section{BASES DE DADOS NACIONAIS}

\section{Portal do CNPq}

O portal de informações criado pelo CNPq visa disseminar trabalhos científicos de professores, pesquisadores e alunos de pós-graduação vinculados às IES. É uma base de dados referencial, com abrangência em todas as áreas do conhecimento e que permite fazer contato com o autor do trabalho para trocar informações e/ou obter textos informativos via e-mail. O acesso é público e está disponível no endereço eletrônico: <http://www.genos.cnpq.br:12010/ dwlattes/owa/consultaprod.inicio>.

\section{Biblioteca Regional de Medicina}

As bases de dados da Biblioteca Regional de Medicina (BIREME) são fontes de informação científico-técnica em saúde que visam disseminar a literatura científica produzida pelos países da América Latina e do Caribe. Atende às áreas de ciências da saúde, engenharia sanitária, documentação de desastres, adolescência, administração de serviços de saúde, odontologia, enfermagem, homeopatia, recursos humanos em saúde e legislação básica de saúde. São bases de dados referenciais e de textos completos com acesso público disponível no endereço eletrônico: <http://www. bireme.br>. 


\section{BASES DE DADOS INTERNACIONAIS}

\section{Pubmed}

Base de dados desenvolvida pelo National Center for Biotechnology Information, da National Library Medicine, a PUBMED reúne a produção científica internacional publicada nas mais conceituadas revistas e/ou publicações disponíveis na área de ciências da saúde. Disponibiliza informações de 1966 até a data atual. É uma base referencial, com acesso público disponível no endereço eletrônico: <http://www.ncbi.nih.gov/entrez/query.fcgi>.

As bases de dados internacionais adquiridas por assinatura são referenciais e de textos completos disponíveis para usuários vinculados às IES. O acesso está disponível nos endereços eletrônicos das bibliotecas das IES através do portal CAPES. As principais bases disponíveis na área biomédica são:

BIOLOGICAL ABSTRACTS - Contém resumos de artigos em biologia, microbiologia, botânica, ecologia, patologia, bioquímica, genética, meio ambiente, veterinária. Disponibiliza informações de 1998 até a atualidade.

HEALTH AND SAFETY COLLeCtion - Contém trabalhos com texto completo em ecologia, desastres naturais, meio ambiente, pesticidas, saúde pública, toxicologia, dentre outras áreas.

JoURNAL@ovid - A mais completa base de dados em medicina; pode conter até 500 revistas de primeira linha, com texto completo dos artigos, imagens, gráficos, etc. Fonte indispensável de informação ao profissional de saúde.

PSYCINFO - Base de dados em ciências sociais, educação, psicologia, psiquiatria. Contém resumos de artigos publicados em periódicos internacionais. (aproximadamente um milhão e meio de registros).

CAB ABSTRACTS - Base de dados com resumos em agricultura, agronomia, fertilizantes, florestas, genética, horticultura, meio ambiente, pesticidas, solos e veterinária.

AGRícola - Contém mais de três milhões de registros com resumos de artigos em: agricultura, agronomia, biologia, botânica, nutrição, pesticidas, solos e veterinária.

INFOTRAC CUSTOM JOURNALS - Disponibiliza resumos e artigos de texto completo em diversas áreas do conhecimento. 
Outros endereços eletrônicos de pesquisa na área da saúde: $<$ http://www.saude.gov.br> - Produzido pelo Ministério da Saúde. Apresenta publicações com texto completo, informações sobre legislação em saúde, conferências e tratados.

<http://www.opas.org.br> - Produzido pela Organização Mundial da Saúde. Disponibiliza publicações da área de saúde com texto completo.

$<$ http://www.saber.usp.br> — Produzido pela Universidade de São Paulo. Trata-se de um banco digital de dissertações e teses produzidas pela pós-graduação da instituição. Algumas apresentam texto completo; outras, só o resumo.

$<$ http://www.ibict.br> - Produzido pelo Instituto Brasileiro de Informação em Ciência Tecnologia. Disponibiliza dissertações e teses. Algumas com texto completo; outras, só o resumo.

\section{FORMAS BÁSICAS DE PESQUISA NAS BASES DE DADOS}

A pesquisa pode ser feita pelo nome do autor, pelo título da publicação, por assunto ou por palavra-chave (palavras em qualquer campo). Formula-se a busca pela composição de termos, com o auxílio dos operadores boleanos, descritos a seguir:

- AND OU E - Intersecção que restringe a busca e recupera apenas os registros com todos os termos solicitados.

Exemplos: cisticercose e cão cisticercosis and dog.

- or ou ou - União que amplia a busca e recupera os registros que contêm qualquer um dos termos pesquisados.

Exemplos: cisticercose e (cão ou gato) cisticercosis and (dog or cat)

- NOT ou NÃo - Negação usada para se excluir determinado conjunto de dados, expresso pelo segundo termo de busca.

Exemplos: câncer e mama e diagnóstico não tratamento neoplasm and breast and diagnosis not treatment

- truncamento - Visa facilitar a formação de expressões de busca quando se deseja recuperar formas variadas com mesmo radical. Exemplos: agricult* e soja

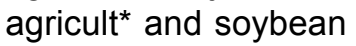

Ao serem combinados, tais operadores possibilitam a recuperação de informações úteis que contenham a especificidade desejada. 
A interface das bases de dados permite imprimir a pesquisa, salvar no disco rígido do computador, gravar em CD ou em disquete.

\section{Portal Capes}

O portal de periódicos é uma ferramenta que facilita as pesquisas bibliográficas ao possibilitar acesso ao texto completo de artigos de revistas internacionais e nacionais. Para entrar no portal, é preciso ter vínculo com as IES e/ou freqüentar as bibliotecas de tais instituições. O portal também oferece acesso público a periódicos com textos completos nos endereços eletrônicos a seguir:

<http://www.freemedicaljournals.com> - texto completo de mais de 860 publicações periódicas na área médica com indicação do fator de impacto e do período a partir do qual elas se tornam disponíveis gratuitamente;

<http://www.scielo.org.br> - periódicos científicos, com texto completo, do Brasil, Chile, Costa Rica, Cuba, Espanha e Venezuela.

\section{Formas básicas de pesquisa no portal CAPES}

A pesquisa pode ser feita por título de periódicos, acessandose a lista geral de títulos em ordem alfabética na busca elaborada através das editoras ou por assunto, através da opção search. São permitidos a impressão dos artigos, o envio por e-mail e a gravação em disquete ou CD, nos formatos PDF (com o Acrobat Reader), html ou txt.

\section{LOCALIZAÇÃO DA DOCUMENTAÇÃO}

O resultado da pesquisa deverá ser muito bem avaliado pelo aluno, ao lado do orientador, para definição dos trabalhos a serem estudados. A etapa seguinte consiste em obter os trabalhos selecionados.

Em primeiro lugar, deve-se consultar o acervo das bibliotecas, acessando-se os catálogos on-line que disponibilizam documentos nos formatos eletrônicos ou impressos. Os documentos encontrados podem ser consultados no próprio local ou emprestados, segundo o regulamento; os indisponíveis no acervo poderão ser obtidos pelo serviço de comutação bibliográfica - troca de documentos entre as bibliotecas que trabalham em rede. Graças ao uso de computadores e a outras inovações tecnológicas, alcançouse um alto grau de eficiência nos serviços de troca de informações. Hoje tanto o pedido como a obtenção de cópias de documentos são feitos com extrema rapidez. $\mathrm{O}$ armazenamento quase ilimitado 
de informação em espaços reduzidos e a transmissão de textos por meio eletrônico disponibilizam a informação num curto espaço de tempo possibilitando a redução de custos.

Para obter trabalhos pela comutação bibliográfica, o usuário pode ir ao setor de referência - onde em geral se presta esse serviço - ou se cadastrar através do endereço eletrônico das bibliotecas e formular pedidos. Cabe ressaltar: é imprescindível a referência bibliográfica completa do documento, que poderá ser obtido gratuitamente ou mediante pagamento, no ato da solicitação. $O$ valor cobrado se destina a custear cópias e envio de trabalhos, feito por correio convencional ou correio eletrônico - dependendo dos recursos disponíveis nas bibliotecas participantes.

\section{LEITURA TÉCNICA}

Obtidos os trabalhos, o próximo passo é estudá-los criticamente. Para começar, recomenda-se a leitura de fontes genéricas dicionários, enciclopédias, dentre outros - para um conhecimento elementar do assunto; a seguir, a leitura dos trabalhos específicos, do mais atual para o mais antigo. A leitura técnica, que auxilia a seleção de documentos relevantes, é um trabalho preliminar, feito através da observação de partes da obra, tais como: folha de rosto, sumário, bibliografia, orelhas, contracapa, introdução, prefácio e resumo.

Segundo Severino (2002, p. 80):

À medida que se procede à leitura e que elementos importantes vão surgindo, faz-se a documentação. Trata-se de tomar notas de todos os elementos que serão utilizados na elaboração do trabalho científico. [...] Esses apontamentos servem de matéria-prima para o trabalho e funcionam como um primeiro estágio de rascunho.

No decorrer da leitura, inicia-se a fase de seleção do conteúdo, que vai gerar apontamentos a serem registrados em fichas de documentação.

\section{FICHAMENTO}

O fichamento pode auxiliar na organização do conhecimento adquirido com as anotações sobre o assunto e pode ser recuperado facilmente, sem necessidade de consulta ao documento original. De acordo com De Cesaro e Bacchin (2003), as fichas devem conter, além do corpo da citação, a referência bibliográfica do trabalho lido. 
As anotações poderão ser de resumos, transcrições de textos ou conclusões do pesquisador. No caso de comentários, convém indicar de forma breve a matéria tratada - o que não significa copiar o índice de matérias, mas sim indicar, com clareza, o tema, o ponto de vista ou aspecto que o autor desenvolve, o modo como o faz, o método que emprega e as conclusões a que chega.

As fichas são importantes instrumentos de trabalho, por isso devem ser organizadas de forma a facilitar a recuperação de seus conteúdos; uma opção é a ordem alfabética por autor ou assunto.

\section{ESTRUTURA DO DOCUMENTO}

De acordo com a NBR 14724, da Associação Brasileira de Normas Técnicas - ABNT (2002), "a estrutura de tese, dissertação ou de um trabalho acadêmico compreende: elementos pré-textuais, elementos textuais e elementos pós-textuais".

- Elementos pré-textuais

Incluem:

Capa - obrigatória (Anexo I)

Deve conter dados que permitam a correta identificação do trabalho:

- nome da instituição (opcional);

- nome do autor;

- título;

- subtítulo;

- número de volumes (se houver mais de um);

- local (cidade da instituição onde deve ser apresentado o trabalho);

- ano.

\section{Lombada - opcional}

Folha de rosto - obrigatória (Anexo II)

Deve conter:

- nome completo do autor;

- título complementado pelo subtítulo, quando houver;

- especificação do tipo de trabalho: se dissertação ou tese;

- nome da unidade/instituição ao qual será submetido;

- título acadêmico pretendido;

- área de concentração;

- nome do orientador;

- local (cidade);

- ano. 
Ficha catalográfica - obrigatório

Deve ser elaborada pelo serviço da biblioteca da instituição a que o trabalhão se vincula e colocada no verso da folha de rosto.

Folha de aprovação da banca examinadora — obrigatória (Anexo III) Deve conter:

- nome do autor do trabalho;

- título do trabalho;

- natureza;

- objetivo;

- nome da instituição;

- área de concentração;

- data de aprovação;

- nome, titulação dos participantes da Banca Examinadora e instituições a que pertencem.

Obs.: data da aprovação e assinatura dos membros da banca examinadora devem ser colocadas após a aprovação do trabalho.

Dedicatória - opcional (Anexo IV)

Nesta página, o autor presta homenagens ou dedica o trabalho.

Agradecimentos - opcional (Anexo V)

Embora opcionais, os agradecimentos devem ser dirigidos a pessoas e instituições que contribuíram de maneira relevante para a realização da pesquisa e elaboração do trabalho.

Epígrafe - opcional (Anexo VI)

Composta por uma frase ou pensamento, normalmente vem localizada no fim da página.

Resumo (na língua vernácula) - obrigatório

O resumo é a apresentação concisa dos pontos relevantes do trabalho. Deve-se ressaltar objetivos, métodos empregados, resultados e conclusões. Usa-se preferencialmente a terceira pessoa do singular. Deve ser redigido em parágrafo único e conter no máximo 500 palavras, segundo a NBR 6028 da ABNT (1990). Recomenda-se a inclusão de palavras-chave após o texto.

Abstract (resumo na língua estrangeira) - obrigatório

O abstract é a tradução para o inglês do resumo em português. Recomenda-se, após o texto do abstract, a inclusão de key words (palavras-chave). 
Lista de ilustrações - opcional

Relação de gráficos, fórmulas, lâminas, figuras (desenhos, gravuras, mapas e fotografias) na mesma ordem em que são citadas no trabalho, com indicação da página onde se localizam.

\section{Lista de tabelas - opcional}

Relação das tabelas na mesma ordem em que são citadas no trabalho, com indicação da página onde estão localizadas.

Lista de abreviaturas e siglas - opcional (anexo VII)

Relação alfabética das abreviaturas e siglas utilizadas na publicação, seguidas das palavras a que correspondem e escritas por extenso.

\section{Lista de símbolos - opcional}

Relação de sinais convencionados usados no texto, seguidos dos respectivos significados.

\section{Sumário - obrigatório (Anexo VIII)}

Enumeração das principais divisões, seções e outras partes de um documento, na mesma ordem em que nele se sucedem. Não confundir sumário com índice.

\section{- Elementos textuais}

Recomenda-se a utilização da NBR 6024 da ABNT (1989), que trata da numeração progressiva das seções de um documento para definir as divisões e subdivisões de uma dissertação ou tese.

\section{Introdução}

É a parte do texto que apresenta o assunto, os objetivos e as finalidades do estudo, informando métodos empregados, delimitação precisa da pesquisa em relação ao campo de conhecimento e períodos abrangidos.

\section{Revisão da literatura}

Exposição da literatura relevante existente na área; comprova-se sua veracidade citando-se os autores e/ou trabalhos pesquisados.

\section{Material e métodos}

Descrição de métodos, materiais e equipamentos utilizados, de modo a se permitir a repetição dos ensaios por outros pesquisadores. Modelos de questionários e entrevistas ou quaisquer outros materiais complementares usados na pesquisa podem ser apresentados nos anexos. 


\section{Resultados}

Devem ser expostos de forma objetiva, clara e lógica; podem ser acrescidos de quadros, figuras, fotografias e ou tabelas que complementam o texto.

\section{Discussão}

Nesta etapa, os resultados da pesquisa são analisados, criticados e comparados com os já existentes sobre o assunto na literatura citada; são discutidos as possíveis implicações, os significados e as razões para concordância ou discordância com outros autores.

\section{Conclusões}

As conclusões devem ser apresentadas de forma lógica, clara e concisa - fundamentando os resultados obtidos na discussão - e mostrar correspondência aos objetivos propostos. Aqui se reafirma a hipótese, cuja demonstração constitui o corpo do trabaIho; trata-se de um regresso à introdução para fechar o início do texto - dessa vez, com sua importância direta e especificamente explicitada.

- Elementos pós-textuais

Incluem:

\section{Referências (obrigatório)}

As referências dos documentos citados devem ser relacionadas após as conclusões. Os documentos consultados e não citados também devem ser aí listados, em ordem alfabética. Recomenda-se a adoção da norma técnica da ABNT NBR 6023 para normalização das referências.

\section{Glossário - opcional}

Lista termos e expressões de uso restrito ou sentido obscuro citados no texto, organizados alfabeticamente e acompanhados dos respectivos significados.

\section{Apêndices - opcional}

Os apêndices, em geral, constituem desenvolvimentos autônomos elaborados pelo próprio autor, para complementar o raciocínio. Contém informações elucidativas e ilustrativas, mas não essenciais ao entendimento do texto.

\section{Anexos - opcional}

São partes integrantes do trabalho, e nem sempre do autor, mas destacadas do texto para evitar a descontinuidade na lógica 
das idéias. Constituem suportes elucidativos e ilustrativos que funcionam como complementos ou instrumentos de trabalho usados na pesquisa, a exemplo dos questionários.

Índices - opcional

Enumeração detalhada de assuntos; nomes de pessoas, geográficos; acontecimentos, dentre outros elementos, com indicação de localização no texto. Fica comumente na parte final do trabalho.

\section{REDAÇÃO E FORMATAÇÃO}

\section{RedAção do TEXTo}

A redação de um trabalho científico requer linguagem concisa e objetiva (referencial); o texto deve primar pela clareza e apresentar um desdobramento lógico do tema. É importante que o pesquisador submeta o rascunho à apreciação de uma ou mais pessoas que conheçam o assunto e possam analisar criticamente o trabalho, a fim de testar a clareza do texto e a linguagem utilizada pelo autor (DE CESARO; BACCHIN, 2003).

\section{Citações no texto}

Toda informação mencionada pelo autor, mas colhida em outra fonte, caracteriza uma citação. De acordo com a NBR 10520 da ABNT (2002) - sobre como dispor a citação em documentos - , as citações podem ser indiretas (livres) ou diretas (textuais).

A citação indireta reproduz idéias e informações do documento, sem, entretanto, copiar as palavras dos autores. Exemplos:

Segundo Mendes (1996) o trabalhador se utiliza de estratégias defensivas individuais ou coletivas para suportar a angústia e insatisfação no trabalho.

ou:

Embora o método Kaiser seja pouco conhecido, ele foi discutido há, aproximadamente, 25 anos (LEBART; DREYFEIS, 1972).

A citação direta transcreve literalmente o texto de outros autores; trata-se de cópia fiel ao que está no original, a ser escrita entre aspas ou como parágrafo à parte, recuado e sem aspas.

A citação direta com até três linhas, deve vir junto ao texto, entre aspas. Exemplo:

"Construção lógica ou síntese é a coordenação inteligente das idéias conforme as exigências racionais da sistematização própria do trabalho." (SEVERINO, 2002, p. 81). 
Com mais de três linhas, a citação direta deve constituir parágrafo independente, com recuo na margem esquerda (quatro centímetros), tamanho de letra menor que o usado no texto, sem aspas e espaço entrelinha 1. Exemplo:

A conclusão é a síntese para a qual caminha o trabaIho. Será breve e visará recapitular sinteticamente os resultados da pesquisa elaborada até então. Se o trabalho visar resolver uma tese-problema e se, para tal, o autor desenvolver uma ou várias hipóteses, através do raciocínio, a conclusão aparecerá como um balanço do empreendimento. O autor manifestará seu ponto de vista sobre os resultados obtidos, sobre o alcance dos mesmos. (SEVERINO, 2002, p. 83).

A citação de citação é a menção a um documento inacessível, mas do qual se tomou conhecimento em outro trabalho. Autor ou obra citados no texto devem ser referidos usando-se a expressão latina apud (citado por, segundo, conforme). A citação de citação deve ser usada com parcimônia, isto é, quando for impossível o acesso ao original ou se tratar de obra rara (BERALDO; PEREIRA, 2001; SILVA; PINHEIRO; FREITAS, 2003). Exemplo:

(EVANS, 1987 apud ABREU, 1999)

ou

Segundo Evans (1987 apud ABREU, 1999)

A citação pode ser feita em diferentes seções do trabalho. $\mathrm{Na}$ introdução, deve-se citar a literatura diretamente relacionada ao tema e que sirva de apoio à apresentação do objetivo do estudo. $\mathrm{Na}$ seção de material de métodos, citam-se somente referências a técnicas e métodos empregados na pesquisa. A seção resultados não comporta citações, porque contém apenas os resultados da investigação em pauta. Na discussão, as citações bibliográficas devem sustentar as hipóteses enunciadas ou explicar pontos em que os resultados se opõem àqueles da literatura. $O$ resumo não deve conter citações.

As citações devem ser indicadas no texto - ou pelo sistema autor-data, ou pelo sistema numérico. O sistema adotado deve ser usado em todo o trabalho e permitir correlação com a lista de referências ou as notas de rodapé.

\section{NotAs DE RODAPÉ}

Objetivam incluir informações complementares feitas pelo autor. Podem ser explicativas ou de referência. Aparecem preferencialmente ao pé da página onde foram citadas. Devem ser numera- 
das em seqüência, com algarismos arábicos, e vir separadas do texto por um filete de 2 a 3 centímetros. É comum as notas serem acompanhadas de expressões em latim.

\section{REFERÊNCIAS}

A NBR 6023 da ABNT (2002) fixa a ordem dos elementos nas referências. Ela estabelece as formas de apresentação da informação originada do documento e/ou outras formas de informação e as regras gerais de apresentação para documentos no todo ou em parte, artigos de revista, trabalhos apresentados em eventos, documentos jurídicos, documentos iconográficos e outros, os quais podem ser apresentados em formato impresso ou em meio eletrônico.

As referências se constituem de elementos essenciais, acrescidos de elementos complementares, quando necessários, e de acordo com o tipo de documento. Os elementos essenciais são informações indispensáveis à identificação das publicações citadas em qualquer trabalho, tais como autor, título e edição; os complementares são informações que permitem caracterizar melhor as publicações referenciadas, por exemplo: as séries, ISBN, notas especiais, dentre outros (SILVA; PINHEIRO; FREITAS, 2004).

\section{Regras gerais}

$\rightarrow$ Ao consultar documentos impressos, retirar preferencialmente as informações da folha de rosto.

$\rightarrow$ Anotar a referência completa após a consulta a qualquer documento para facilitar a compilação das referências.

$\rightarrow$ Anotar o endereço eletrônico (URL) e a data do acesso do documento em meio eletrônico (internet).

$\rightarrow$ Adotar uma padronização na elaboração da lista de referências.

\section{Exemplos de referências}

\section{Livro no todo}

Exemplo:

MOORE, K. L.; PERSAUD, T. V. N. Embriologia básica. Tradução de Ithamar Vugman; Mira de C. Engelhardt. 5. ed. Rio de Janeiro: Guanabara Koogan, 2000. 453p.

\section{Capítulo de livro sem autoria própria} Exemplo: 
TURGEON, M. L. Labeling techniques in immunoassay. In:

Immunology and serology in laboratory medicine. 2nd ed. Saint Louis: Mosby, 1996. p. 151-158.

Capítulo de livro com autoria própria Exemplo:

RODRIGUEZ-CARBAJAL, J.; DURAN, B. B.; DORSFMAN, J. EI diagnostico de la neurocisticercosis humana por tomografía computada. In: FLISSER, A.; MALAGON, F. (Ed.) Cisticercosis humana y porcina: su conocimiento e investigación en Mexico. Mexico: Limusa, 1989. p. 77-86.

Dissertações e teses

Exemplo:

MINEO, J. R. Detecção de antígenos e de anticorpos, com técnicas imunoenzimáticas, para o diagnóstico sorológico da toxoplasmose "aguda". 1982. 97f. Tese (Doutorado em Microbiologia e Imunologia) - Instituto de Ciências Biomédicas, Universidade de São Paulo, São Paulo, 1982.

Trabalhos apresentados em eventos Exemplo:

UIP, D. E. Prevenção da AIDS e hepatite B. In: CONGRESSO DA ASSOCIAÇÃO BRASILEIRA DE MEDICINA DE GRUPO, 7., 1999, Cabo de Santo Agostinho. Anais... São Paulo, 1999. p. 92-98.

\section{Artigos de revista}

Exemplo:

LEAL, N. C. et al. Homologia entre bandas extras de DNA críptico e os plasmídios típicos em cepas brasileiras de Yersina pestis. Brazilian Journal of Microbiology, São Paulo, v. 31, n. 1, p. 20-24, jan./mar. 2000.

Documentos apresentados em formato eletrônico Exemplo:

NOZAIS, J. P. The origin and dispersion of human parasitic diseases in the Old World (Africa, Europe and Madagascar). Memórias do Instituto Oswaldo Cruz, Rio de Janeiro, v. 98, n. 1, p. 13-19, jan. 2003. Suplemento. Disponível em: <http://www.scielo.com.br>. Acesso em: 29 ago. 2003. 
De acordo com Beraldo e Pereira (2000), as dificuldades em organizar os trabalhos científicos podem ser amenizadas usandose programas para microcomputador chamados "sistemas de gerenciamento bibliográfico". São uma ferramenta vital para armazenamento, recuperação, citação e organização de referências - em particular na produção científica da área biomédica.

\section{ForMATAÇÃo DA APRESENTAÇÃo}

A apresentação de trabalhos acadêmicos deve ser elaborada conforme os procedimentos da NBR 14724, da ABNT (2002), descritos a seguir.

\section{Formato}

Os textos devem ser apresentados em papel branco, formato $\mathrm{A} 4$, impressos em preto, no anverso das folhas. Recomenda-se letra de tamanho 12 para a digitação. As margens da esquerda e superior devem ter três centímetros; da direita e inferior, dois centímetros. O espaço entrelinha de todo o texto deve ser 1,5 . Todas as páginas do trabalho, a partir da folha de rosto, devem ser contadas em seqüência, mas não numeradas. A numeração só começa na primeira página textual, em algarismos arábicos, no canto superior direito da página.

Caso o trabalho tenha mais de um volume, deve ser mantida apenas uma seqüência de numeração de páginas, do primeiro ao último volume. Se houver apêndice e anexo, as respectivas páginas devem ser numeradas de maneira contínua, e a paginação deve seguir à do texto principal.

\section{CONCLUSÃO}

Neste capítulo, foram descritos os passos necessários à elaboração de um trabalho científico. Baseou-se na literatura disponível sobre o tema e nas normas da ABNT. A proposta principal foi destacar os aspectos da padronização para um trabalho de melhor qualidade.

\section{REFERÊNCIAS}

ASSOCIAÇÃO BRASILEIRA DE NORMAS TÉCNICAS. NBR 6023: referências bibliográficas. Rio de Janeiro, 2002. 24p.

NBR 6024: numeração progressiva em documentos. Rio de Janeiro, 1989. 2p. 
NBR 10520: apresentação de citação em documentos. Rio Janeiro, 2002. 7p.

NBR 14724: informação e documentação; trabalhos acadêmicos: apresentação. Rio de Janeiro, 2002. 6p.

. NBR 6028: resumos. Rio de Janeiro, 1990. 3p.

BERALDO, P. S. S.; PEREIRA, M. G. Sistema de gerenciamento bibliográfico; parte 1: armazenamento e recuperação da referências. Brasília Médica, Brasília, v. 37, n. 3/4, p. 119-122, 2000.

Sistema de gerenciamento bibliográfico; parte 2: citação e organização da lista de referência. Brasília Médica, Brasília, v. 38, n. 1/4, p. 52-57, 2001.

DE CESARO, B. B.; BACCHIN, M.I. Elaboração de monografias: aspectos técnicos. Uberlândia: Universidade Federal de Uberlândia, 2003. 22 p. Apostila.

LEMOS, A. A. B. Infra-estrutura da literatura biomédica: considerações acerca de um núcleo de revistas brasileiras do setor saúde. Educacion Medica Y Salud, Washington, v. 15, n. 4, p. 406-423, 1981.

SEVERINO, A. J. Diretrizes de uma monografia científica. In: Metodologia do trabalho científico. 22. ed. rev. ampl. São Paulo: Cortez, 2002. p. 73-132.

SILVA, A. M.; PINHEIRO, M. S. de F.; FREITAS, N. E. de. Guia para normalização de trabalhos técnicos-científicos: projetos de pesquisa, monografias, dissertações, teses. 4. ed. rev. Uberlândia: EDUFU, 2004. 145p.

Nota do editor:

Os anexos a seguir são sugeridos para a formatação em papel tamanho A4 (210x297mm). Aqui, eles estão apresentados em redução proporcional, uma vez que este livro utiliza outro formato de papel. 
ANEXO A - Modelo de capa (dissertação ou tese)

UNIVERSIDADE FEDERAL DE UBERLÂNDIA

ARLETE GOMES ROSA

ESTRUTURA DA COMUNIDADE ARBÓREA EM UM REMANESCENTE FLORESTAL URBANO

(PARQUE DO SABIÁ, UBERLÂNDIA, MG)

UBERLÂNDIA

2002 
ANEXO B - Modelo de folha de rosto

ARLETE GOMES ROSA

ESTRUTURA DA COMUNIDADE ARBÓREA

EM UM REMANESCENTE FLORESTAL URBANO

(PARQUE DO SABIÁ, UBERLÂNDIA, MG)

Dissertação apresentada à Universidade Federal de Uberlândia, como parte dos requisitos para obtenção do título de Mestre em Ecologia e conservação de Recursos Naturais.

Orientador: Prof. Dr. Ivan Schiavini

UBERLÂNDIA

2002 
ANEXO C - Folha de aprovação

\section{ARLETE GOMES ROSA}

\section{ESTRUTURA DA COMUNIDADE ARBÓREA}

EM UM REMANESCENTE FLORESTAL URBANO (PARQUE DO SABIÁ, UBERLÂNDIA, MG)

Dissertação apresentada à Universidade Federal de Uberlândia, como parte das exigências para a obtenção do título de Mestre em Ecologia e Conservação de Recursos Naturais.

Aprovada em

Prof. Dr. João Renato Stehmann - UFMG

Prof. Dr. Glein Monteiro de Araujo - UFU

Prof. Dr Paulo Eugênio Oliveira - UFU (Suplente)

Prof Dr. Ivan Schiavini (Orientador)

UBERLÂNDIA 


\section{ANEXO D - Dedicatória}

A vocês que me deram a vida e me ensinaram a vivê-la com dignidade.

A vocês que iluminaram os caminhos obscuros com afeto e dedicação,

para que eu trilhasse sem medo e cheia de esperança.

$A$ vocês que se doaram por inteiro e renunciaram aos próprios sonhos para que eu, muitas vezes, pudesse realizar os meus.

A vocês, pais por natureza, opção e amor... Muito obrigada. 
ANEXO E - Agradecimentos

\section{AGRADECIMENTOS}

A Deus, pelo Dom da persistência, da perseverança e do fascínio pelo "desconhecido" que me dotou.

Ao paciente que, em busca da saúde, contribui para mais um passo rumo ao conhecimento científico.

À direção do hospital universitário da Universidade Federal de Uberlândia, pelo apoio logístico.

À equipe do centro de endoscopia do hospital universitário, colaboradores fundamentais do início ao fim deste trabalho. 
ANEXO F - Epígrafe

Cada um que passa em nossa vida, passa sozinho, pois cada pessoa é única e nenhuma substitui a outra.

Cada um que passa em nossa vida, passa sozinho, mas não vai só, nem nos deixa sós, deixa um pouco de si mesmo. Há os que levam muito, mas há os que levam nada, há os que deixam muito, mas há os que não deixam nada.

Esta é a maior responsabilidade de nossa vida, é prova evidente de que duas almas não se encontram por acaso. (SAINT-EXUPÉRY) 
ANEXO G - Listas

\section{LISTA DE ABREVIATURAS E SIGLAS}

$\mathrm{BHI}$ - Brain- heart-infiusion

CAPES - Comissão de Aperfeiçoamento de Pessoal do Ensino Superior

DNU — Dispepsia não ulcerosa

EDA - Endoscopia digestiva alta

ELISA - Enzyme Linked Immunosorbent Assay

FDA - Food and Drug Administration

GC - Gastrite crônica

GCA - Gastrite crônica alta

$\mathrm{KDa}$ - Kilodalton

OR - Odds ratio

PCR - Polymerase Chain Reaction

UD - Úlcera duodenal 
ANEXO H - Sumário

\section{SUMÁRIO}

\section{RESUMO}

\section{ABSTRACT}

1 - INTRODUÇÃO

1.1 LECTINAS 06

1.1.1 Aspectos gerais 07

1.1.2 Lectinas presentes em microorganismos 08

1.1.3 Lectinas presentes em animais vertebrados e invertebrados $\quad 13$

1.1.4 Lectinas presentes em vegetais 15

1.1.5 Caryocar brasiliensis $\quad 18$

2 - OBJETIVOS 21

3 - MATERIAL E MÉTODOS 22

3.1 Obtenção do extrato fenólico 23

3.2 Obtenção do extrato clorofórmio-metanólico 26

3.3 Dosagem protéica e de polissacárideos 27

$\begin{array}{lll}3.4 & \text { SDS-PAGE } & 27\end{array}$

4 - RESULTADOS 30

5 - DISCUSSÃO 40

6 - CONCLUSÕES 50

REFERÊNCIAS BIBLIOGRÁFICAS 53 
3.

\title{
ÉTICA EM PESQUISA NA ÁREA BIOMÉDICA
}

\author{
Luiz Henrique Guerreiro Vidigal \\ Deise Aparecida de Oliveira Silva
}

\section{PESQUISA EM SERES HUMANOS}

\section{INTRODUÇÃO}

No capítulo 10 deste livro, que trata do modelo de estudo sobre terapêutica, cita-se como exemplo antiético a proposta de um estudo experimental que compara dois grupos de pacientes portadores de AIDS sob uso ou não do coquetel anti-retroviral. Indo mais longe, afirmou-se que tal estudo nem sequer seria aprovado pelo Comitê de Ética em Pesquisa a que fosse submetido. Assim, neste capítulo pretende-se expor o que está normatizado hoje em relação à ética em pesquisa com seres humanos; busca-se, aqui, delinear os princípios a serem respeitados, sem se recorrerem a elucubrações filosóficas.

Do grego ethike ("moral"), ética é a parte da filosofia que aborda os fundamentos da moral. Tal definição claramente inclui dois aspectos fundamentais referentes à questão ética: subjetividade e complexidade. O primeiro, no caso específico de pesquisa com seres humanos, pelo simples fato de tratar da moral relativa ao envolvimento de pessoas submetidas a algum tipo de tratamento que vai envolver questões legais e humanitárias; a segunda, pelo fato de, certamente, as leis de qualquer país não preverem todas as situações nem todos os avanços técnico-biológicos - nesse caso, cabe a um grupo de pessoas (membros do Comitê de Ética em Pesquisa) julgar e decidir o desenvolvimento ou não da pesquisa em termos éticos. Como o objetivo é sempre beneficiar o ser humano com os avanços médicos - clínicos ou cirúrgicos - porém com respeito ao princípio imprescindível de primo non nocere (primeiro, não causar mal), a decisão nem sempre é fácil. Não causar danos ao indivíduo e ao mesmo tempo conseguir avanços com os resultados desejados, muitas vezes, é tarefa árdua, cercada de polêmicas e pormenores. 


\section{UM BREVE HISTÓRICO}

Vários documentos em diferentes países foram elaborados nos últimos 50 anos, mais exatamente a partir de 1947, quando há um marco decisivo na ética em pesquisa com serem humanos: o Código de Nuremberg. É claro que isso não foi por acaso; havia uma necessidade imensa de se garantir integridade física e mental aos seres humanos após as atrocidades impostas aos judeus concentrados em campos nazistas durante a Segunda Guerra Mundial.

É verdade que documentos já promulgados buscavam limitar a ação médica sem intenções bem definidas - como aquele redigido em Berlim na então Prússia (atual Alemanha), em 1901, intitulado "Instrução sobre intervenções médicas com objetivos outros que não diagnóstico, terapêutica ou imunização (Anweisung an die Vorsteher der Kliniken, Polikliniken under sinstigen Krankenanstakten)". Em 1931, ainda na Alemanha e também na era préSegunda Guerra, foi estabelecida uma legislação para controlar, com rigor, os experimentos em seres humanos: "Diretrizes para novas terapêuticas e pesquisa em seres humanos". Assim, embora as experiências no campo de concentração judeu de Auschwitz tenham trazido avanços para a ciência médica — por mais desumanas, cruéis e imorais que tenham sido - , a dor humana, mental e espiritual, a que milhões de inocentes tiveram de ser submetidos não justifica o fim pretendido e conseguido.

Do ponto vista evolutivo, surgiram documentos em diferentes partes do mundo ao longo deste tempo; os mais importantes são listados no Quadro 3.1.

\begin{tabular}{|c|c|}
\hline Data Documento & Origem / Fonte \\
\hline 1947 Código de Nuremberg & $\begin{array}{l}\text { Tribunal Internacional } \\
\text { de Nuremberg }\end{array}$ \\
\hline $\begin{array}{l}1948 \text { Declaração dos Direitos do } \\
\text { Homem }\end{array}$ & Organização das Nações Unidas \\
\hline $\begin{array}{l}1964 \text { Declaração de Helsinque e suas } \\
\text { revisões }(1975,1983 \text { e 1989) }\end{array}$ & Helsinque, Alemanha \\
\hline 1966 Acordo Internacional sobre & Congresso Nacional Brasileiro em \\
\hline Direitos Civis e Políticos & 1992 \\
\hline $\begin{array}{l}1978 \text { Declaração Universal dos Direitos } \\
\text { do Homem }\end{array}$ & Paris, França \\
\hline $\begin{array}{l}1982 \text { Propostas de Diretrizes Éticas Inter- } \\
\text { nacionais para Pesquisas Biomédicas } \\
\text { Envolvendo Seres Humanos } \\
\text { (revisões em 1993) }\end{array}$ & ClOMS/OMS \\
\hline 1991 Diretrizes Internacionais para Revisão & CIOMS; Conselho Federal de \\
\hline Ética de Estudos Epidemiológicos & Medicina. Brasil (1997) \\
\hline 1996 Resolução n 196/96 & Conselho Nacional de Saúde, Brasil \\
\hline
\end{tabular}

QuADro 3.1 - Evolução histórica dos documentos referentes ao controle da pesquisa em seres humanos 


\section{RESOLUÇÃO 196/96}

O Conselho Nacional de Saúde (CNS) — órgão vinculado ao Ministério da Saúde (MS) — aprovou a resolução 196/96, que prevê as diretrizes e normas regulamentadoras de pesquisas que envolvem seres humanos no Brasil. Elas são fundamentadas nos diversos documentos internacionais já citados e listados no preâmbulo de tal resolução e se alinham à Constituição de 1988. Conforme o documento especifica, as diretrizes incluem os quatro princípios básicos da bioética - autonomia, não-maleficência, beneficência e justiça -, de forma a se garantirem os direitos não só do cidadão, mas também da coletividade.

A seguir, as principais divisões do documento, com seus aspectos referentes à ética propriamente dita, são comentadas de forma resumida.

Item III dA RESOluÇão 196/96 - Aspectos Éticos dA PESQUisa enVoLVENDO SERES HUMANOS

- Aborda a importância da autonomia no que se refere a observar a dignidade do indivíduo, respeitando-lhe o direito de não participar de determinada pesquisa caso isso não seja a vontade dele.

- Inclui a necessidade de haver mais benefícios do que riscos (beneficência), de se evitarem riscos previsíveis (não-maleficência) e destinação sociohumanitária da pesquisa (justiça).

- Inclui qualquer procedimento referente ao ser humano (o paciente em questão) que ainda não esteja consagrado pela literatura como pesquisa, seja qual for o grau de invasividade; assim, leitura do prontuário do paciente e atendimento ambulatorial com finalidade de estudo são considerados procedimentos de pesquisa, da mesma forma que cirurgia ou coleta de sangue - ainda que com finalidades distintas.

- Prevê pesquisas em seres humanos somente após comprovações da eficácia e segurança do procedimento in vitro (em se tratando de drogas) e em animais de laboratório, com o intuito de se comprovarem benefícios ainda não atestados.

- Garante que, quando utilizado placebo, o procedimento seja metodologicamente justificável e prevista a não-maleficência.

- Observa a garantia de acesso do paciente submetido a estudo aos benefícios do tratamento, não limitados ao período do estudo. Isso é também verdadeiro para toda a comunidade em termos de mudança de hábitos e costumes com os quais se atestem benefícios.

- Prevê comprovação das vantagens de pesquisas conduzidas do exterior ou com colaboração estrangeira, tanto para os indivíduos 
da pesquisa quanto para o Brasil; os pesquisadores envolvidos na investigação devem participar de treinamento que poderá ser aproveitado depois para o desenvolvimento de pesquisas semelhantes, mas de maneira independente.

\section{ITEM IV DA RESOLUÇÃo 196/96 — Consentimento LiVRE E ESCLARECiDo}

- Garante que toda pesquisa só tenha início após consentimento livre e esclarecido dos sujeitos, indivíduos ou grupos envolvidos anuência essa que pode também ser expressa por representantes legalmente constituídos.

- Aborda o que o documento deve conter para que possa, por um lado, ser claro por meio de linguagem acessível aos pacientes e, por outro lado, abrangente o bastante para esclarecer objetivos, justificativas, riscos implicados, alternativas de tratamento e mesmo aspectos financeiros - como ressarcimento de despesas durante a pesquisa - dentre outros pontos.

- Faz constar a necessidade de o termo de consentimento ser elaborado pelo pesquisador responsável e ser aprovado pelo Comitê de Ética em Pesquisa.

- Faz observar as situações em que pode haver limitações à obtenção do termo de consentimento e, logo, necessidade de justificativa forte o suficiente para que tais limitações não sejam consideradas, de fato, obstáculos à inclusão dos pacientes, conforme julgamento do Comitê de Ética em Pesquisa. Situações de necessidade de inclusão de crianças e adolescentes, doentes mentais, comunidades culturalmente diferenciadas e até pacientes com morte encefálica atestada são listadas neste item.

\section{ITEM V dA RESOLUÇÃo 196/96 — Riscos E benefícios}

- Define que toda pesquisa incluindo seres humanos envolve riscos, ao mesmo tempo em que objetiva os cenários em que se admite a ocorrência de riscos.

- Trata da responsabilidade do pesquisador quanto à assistência integral aos pacientes que possam sofrer complicações conseqüentes aos riscos previstos.

- Faz constar a necessidade de interrupção do estudo assim que comprovada a superioridade do método em estudo, de forma a beneficiar todos os participantes com o melhor regime.

- Engloba a indenização a ser conferida aos participantes em caso de dano comprovado a saúde deles. Exclui a possibilidade de haver cláusula no termo de consentimento que afaste a probabilidade de o paciente abrir mão de qualquer/quaisquer direito(s) legal(is), inclusive a indenização. 


\section{Item VII da Resolução 196/96 - Comitê de Ética em Pesquisa (CEP)}

- Toda pesquisa envolvendo seres humanos deverá ser submetida

à apreciação de um Comitê de Ética em Pesquisa.

- Define que toda instituição onde se realizam pesquisas com seres humanos deve constituir um comitê de ética de inteira competência da instituição.

- Prevê que tal comitê deverá ser constituído por profissionais de diferentes áreas: saúde, ciências exatas, sociais e humanas, além de, pelo menos, um membro da sociedade que represente os usuários da instituição.

- Define que uma instituição poderá constituir mais de um comitê de ética conforme a necessidade. Caso não haja um conselho constituído em dado local de ensino, ou mesmo por necessidade de momento (como exigüidade de tempo), a pesquisa pode ser avaliada pelo CEP de outra instituição; no caso de Uberlândia, uma pesquisa desenvolvida na universidade federal poderá ser avaliada, por exemplo, pelo CEP do Centro Universitário do Triângulo (Unitri); o contrário também pode ocorrer.

- Define o CEP como instância em que a pesquisa terá o protocolo aprovado ou não para entrar em funcionamento em dada instituição. Se aprovado, será, em seguida, apreciado pela Comissão Nacional de Ética em Pesquisa (CONEP/MS).

- Inclui o acompanhamento da pesquisa pelo CEP, responsável não só pelo parecer favorável à execução da pesquisa na instituição, mas também pelo acompanhamento: exigir relatórios dos pesquisadores, receber denúncias dos sujeitos envolvidos na pesquisa, podendo decidir pela continuação, modificação ou suspensão da pesquisa, assim como pela adequação do termo de consentimento caso isso se faça necessário.

- Considera anti-ética a descontinuação da pesquisa sem a aceitação do CEP que a aprovou.

$\mathrm{O}$ acesso via internet à folha de rosto para pesquisa envolvendo seres humanos encontra-se disponível nos endereços eletrônicos de cada instituição. No caso da Universidade Federal de Uberlândia, está disponível em: <http://www.propp.ufu.br/cep/folhaderosto.doc>.

Item VIII da resolução 196/96 - Comissão Nacional de Ética em PesQUISA (CONEP) DO MinISTÉRIO dA SAÚdE (MS)

- Estabelece a CONEP/MS como instância colegiada, de "composição multi e transdisciplinar, devendo ser composta por 13 (treze) membros titulares, sendo cinco destes, personalidades destacadas no campo da ética na pesquisa e na saúde e oito personalidades com destacada atuação nos campos teológico, jurídico e outros". 
- Define as atribuições da CONEP, à qual caberá responsabilidade na criação de CEPs institucionais e outras instâncias, apreciação e acompanhamento dos protocolos de pesquisa em diversas áreas temáticas especiais, em que se incluem genética, medicamentos, vacinas, testes diagnósticos e equipamentos novos para a saúde e novos procedimentos ainda não consagrados na literatura.

- A CONEP é órgão vinculado ao Conselho Nacional de Saúde (CNS) e, como tal, deve assessorar o CNS, o Ministério da Saúde e outras instâncias do Sistema Único de Saúde (SUS) sobre questões éticas relativas à pesquisa em seres humanos.

- Como instância colocada hierarquicamente acima dos CEPs, a CONEP pode fazer a revisão ética de pesquisas já aprovadas por esses órgãos e proibir ou interromper pesquisas, de forma definitiva ou temporária.

- Suas funções incluem manter atualizado um banco de dados que componha um sistema de informações e acompanhamento dos aspectos éticos das pesquisas que envolvam seres humanos em todo o território nacional.

Quando se fala dos direitos do cidadão e da coletividade, conforme já citado, é inevitável um paralelo com os direitos civis previstos na Constituição brasileira. $O$ direito à liberdade de expressão garantido pela Constituição tem sua representação refletida no contexto científico - pela garantia à autonomia no que se refere a um cidadão decidir se participa ou não de dado ensaio experimental. Em geral, o que se busca com a normatização das pesquisas científicas envolvendo seres humanos em relação ao indivíduo objeto principal da pesquisa médica - talvez possa ser assim avaliado:

- assegurar que o indivíduo seja totalmente informado dos motivos da pesquisa, a fim de que entenda a razão de se submeter a um novo tipo de tratamento ou procedimento;

- prever a integralidade de assistência médica ao paciente em estudo no caso de haver efeitos colaterais relacionados ao uso da nova terapia;

- garantir, após o estudo, que se estenda o tratamento aos participantes no caso de se atestar a existência de mais benefícios com seu uso do que com o que era preconizado até o momento; - evitar que populações minoritárias - como a indígena - ou potencialmente discrimináveis - como a carcerária — sejam levadas a participar de algo que fira suas tradições ou as obrigue por qualquer tipo de coação.

Além disso, como não poderia ser diferente, a vinculação da CONEP ao Ministério da Saúde tem o claro efeito prático de dar um peso político a ser sentido pelos laboratórios que buscam testar novas drogas, sobretudo aqueles geridos por grandes grupos es- 
trangeiros com atividade no Brasil. Nesse sentido, a começar pelos CEPs, há uma preocupação constante de se evitar que, de alguma forma, sejam testados medicamentos cujos protocolos de pesquisa não esclareçam bem a necessidade de uma nova droga e a possibilidade de benefício. Em resumo, busca-se sempre evitar que pacientes brasileiros incluídos em ensaios experimentais sejam submetidos a algum tipo de tratamento evitado em pacientes de países desenvolvidos, ao menos a princípio. Pode até haver nisso um certo excesso por parte dos CEPs ou mesmo da CONEP em algumas decisões; mas a tentativa é sempre para não prejudicar o paciente e para garantir a incorporação da nova tecnologia pelos profissionais brasileiros.

\section{RESOLUÇÃO 251/97}

Em agosto de 1997, foi promulgada a resolução 251/97 (CONSELHO NACIONAL DE SAÚDE, 1997) para normatizar, sobretudo, a pesquisa com novos fármacos, medicamentos, vacinas e testes diagnósticos envolvendo seres humanos. Com a resolução, buscou-se detalhar as diretrizes da resolução 196/96 para essas áreas temáticas específicas. $O$ texto integral da resolução pode ser acessado no endereço eletrônico <http://www.bioetica.ufrgs.br/ res25197.htm>.

\section{PESQUISA EM SERES HUMANOS RELACIONADOS À ÉTICA MÉDICA}

Assim como a resolução 196/96 normatiza os aspectos técnicos de um protocolo, define o acompanhamento dos CEPs e da CONEP, também protegendo a autonomia e a saúde do paciente a ser incluído em um estudo experimental, o profissional médico responsável pela pesquisa conta com um documento com orientações a seguir sobre sua conduta ética. O Código de Ética Médica (CONSELHO FEDERAL DE MEDICINA, 1988) prevê, em seus capítulos IV, V, XII e XIII, limitações ao trabalho do médico em situações gerais e específicas que têm relação com pesquisas envolvendo seres humanos.

Em seguida, os artigos referentes à pesquisa com seres humanos citados no Código de Ética Médica serão apresentados. Finalizam esta parte comentários sucintos, pois as citações são auto-explicativas.

\section{Capítulo IV - Direitos Humanos}

É vedado ao médico:

Art. 46 - Efetuar qualquer procedimento médico sem o esclareci- 
mento e o consentimento prévios do paciente ou de responsável legal, salvo em iminente perigo de vida.

[...]

Art. 48 - Exercer sua autoridade de maneira a limitar o direito do paciente de decidir livremente sobre a sua pessoa ou seu bemestar.

\section{Capítulo V - Relação com pacientes e familiares É vedado ao médico:}

Art. 57 - Deixar de utilizar todos os meios disponíveis de diagnóstico e tratamento a seu alcance em favor do paciente.

[...]

Art. 70 - Negar ao paciente acesso a seu prontuário médico, ficha clínica ou similar, bem como deixar de dar explicações necessárias à sua compreensão, salvo quando ocasionar riscos para o paciente ou para terceiros.

\section{Capítulo XII - Pesquisa médica}

É vedado ao médico:

Art. 122 - Participar de qualquer tipo de experiência no ser humano com fins bélicos, políticos, raciais ou eugênicos.

Art. 123 - Realizar pesquisa em ser humano, sem que esse tenha dado consentimento por escrito, após devidamente esclarecido, sobre a natureza e conseqüências da pesquisa.

Parágrafo único - Caso o paciente não tenha condições de dar seu livre consentimento, a pesquisa somente poderá ser realizada, em seu próprio benefício, após expressa autorização de seu representante legal.

Art. 124 - Usar experimentalmente qualquer tipo de terapêutica ainda não liberada para uso no país, sem a devida autorização dos órgãos competentes e sem consentimento do paciente, ou de seu responsável legal, devidamente informados da situação e das possíveis conseqüências.

Art. 125 - Promover pesquisa médica na comunidade sem o conhecimento dessa coletividade e sem que o objetivo seja a proteção da saúde pública, respeitadas as características locais.

Art. 126 - Obter vantagens pessoais, ter qualquer interesse comercial ou renunciar à sua independência profissional em relação a financiadores de pesquisa médica da qual participe.

Art. 127 - Realizar pesquisa médica em ser humano sem submeter o protocolo à aprovação e acompanhamento de comissão isenta de qualquer dependência em relação ao pesquisador.

Art. 128 - Realizar pesquisa médica em voluntários, sadios ou não, que tenham direta ou indireta dependência ou subordinação relativa ao pesquisador. 
Art. 129 - Executar ou participar de pesquisa médica sem que haja necessidade de suspender ou deixar de usar terapêutica consagrada e, com isso, prejudicar o paciente.

Art. 130 - Realizar experiências com novos tratamentos clínicos ou cirúrgicos em paciente com afecção incurável ou terminal sem que haja esperança razoável de utilidade para o mesmo, não Ihe impondo sofrimentos adicionais.

Capítulo XIII - Publicidade e trabalhos científicos É vedado ao médico:

Art. 131 - Permitir que sua participação, na divulgação de assuntos médicos, em qualquer veículo de comunicação de massa, deixe de ter caráter exclusivamente de esclarecimento e educação da coletividade.

Art. 132 - Divulgar informação sobre assunto médico de forma sensacionalista, promocional ou de conteúdo inverídico.

Art. 133 - Divulgar, fora do meio científico, processo de tratamento ou descoberta cujo valor ainda não esteja expressamente reconhecido por órgão competente.

[...]

Art. 140 - Falsear dados estatísticos ou deturpar sua interpretação científica.

Nota-se que muitos pontos estão incluídos tanto na resolução 196/96 quanto no Código de Ética Médica, e alguns itens deste, nitidamente, fundamentam artigos da resolução 196/96. Com base nesses documentos, são julgados os protocolos de pesquisa pelos CEPs; neles, também se pauta o acompanhamento das pesquisas. Os atos médicos referentes ao exercício da pesquisa devem ser fundamentados no que prevêem as diretrizes éticas da profissão.

\section{CONCLUSÃO}

A regulamentação da pesquisa envolvendo seres humanos visa sempre beneficiar o paciente, e nunca prejudicá-lo. Dar a ele o direito de escolher o tratamento e participar ou não de ensaios experimentais. Assegurar que os fins sejam sempre puramente clínicos; e no caso de descobertas terapêuticas, os ganhos financeiros devem ficar em segundo plano. Poderão existir dúvidas freqüentes quanto à objetividade desses pontos em algumas pesquisas; e os documentos atuais disponíveis visam pôr um fim, ou ao menos minimizar, dilemas éticos que possam impedir o acesso a um tratamento equivocadamente desaprovado por algum CEP. Acrescentem-se a tais documentos aqueles que surgirem após o início da comercialização de alguma droga testada em todas as fases de um experimento clínico, mas que traz imensos problemas por cau- 
sa de efeitos colaterais não testados ou não previstos e, de alguma forma, não percebidos durante o estudo.

\section{PESQUISA EM ANIMAIS}

\section{INTRODUÇÃO}

Desde a antiguidade, modelos animais têm sido utilizados em pesquisa, como evidenciam os registros de Pitágoras (500 a. C.), Hipócrates (450 a. C.) e dos anatomistas Herophilus (250 a. C.) e Erasistratus (240 a. C.), os quais faziam vivissecções de animais para estudar os órgãos e funcionamento deles. Mais tarde, já no século XVII, destaca-se a publicação intitulada Exercitatio anatomica de motu cordis et sanguinis in animalibus, de William Harvey (1638), que descreve a fisiologia da circulação sanguínea em mais de 80 diferentes espécies de animais.

No entanto, a preocupação com o sofrimento e a proteção dos animais, embora já existisse na Grécia antiga, só começam a ser questionadas em 1789, pelo filósofo Jeremy Benthan, onde a argumentação não é no sentido se eles podem raciocinar, ou então falar, mas podem eles sofrer?

O uso de animais em pesquisa remonta há milhares de anos, mas só com Charles Darwin (1859) - e seu estudo sobre a evolução das espécies animais em A origem das espécies - foi possível extrapolar dados obtidos em pesquisas com modelos animais para seres humanos. Logo após, Claude Bernard (1865) com a publicação de An introduction to the study of experimental medicine - enfatizou o uso de animais em pesquisas, pois "seria estranho se reconhecêssemos o direito de usar os animais para serviços caseiros e alimentação, e proibir o seu uso para o ensino de uma das ciências mais úteis para a humanidade".

Em seguida, surgem várias publicações sobre aspectos éticos da utilização de animais em experimentação científica. A primeira lei a regulamentar o uso de animais em pesquisa foi proposta no Reino Unido, em 1876. Em 1909, a Associação Médica Americana lançou a primeira publicação sobre o tema. Entretanto, só em 1959, Russel e Burch estabeleceram o princípio dos três "Rs" (replace, reduce e refine) para a pesquisa em animais:

- refine: refinamento de técnicas utilizadas no manejo dos animais para diminuir a dor e o sofrimento durante os experimentos (métodos adequados para analgesia, assepsia e eutanásia);

- reduce: redução do número de animais utilizados através de técnicas e abordagens mais apropriadas para esta finalidade e aplicação de testes estatísticos mais adequados a pequenas amostras; 
- replace: substituição, parcial ou total, dos animais por métodos alternativos (experimentos in vitro, modelos matemáticos e simulações por computador).

O princípio dos "3 Rs" é adotado internacionalmente como necessidade para adequação da pesquisa em modelos animais e pode ser assim resumido: qualquer técnica que refine um método existente para diminuir a dor e o desconforto dos animais, que reduza seu número em um trabalho particular ou que substitua o uso de uma espécie animal por outra, de categoria inferior na escala zoológica, ou por métodos computadorizados ou in vitro, deve ser considerada como método alternativo.

Em dias atuais, os países desenvolvidos e os em desenvolvimento se interessam e discutem a regulamentação de suas atividades de pesquisa envolvendo modelos animais, por causa do uso crescente de animais em pesquisas e, sobretudo, das condições a que eram submetidos em pesquisas industriais - em particular, aquelas ligadas a cosméticos e produção de alimentos. Essa questão foi polemicamente debatida por Singer em Animal Liberation (1975).

\section{PRINCÍPIOS DA PESQUISA CIENTÍFICA COM ANIMAIS}

Hoje a pesquisa científica envolvendo animais é conduzida e orientada por princípios que levam em consideração vários fatores, dentre os quais:

1. justificativa para usar animais - o homem precisa utilizar animais não apenas para suprir necessidades básicas de alimentação, vestimenta e trabalho, mas também para o avanço dos conhecimentos na área de saúde humana e animal. Assim, projetos de pesquisa envolvendo animais representam uma alternativa ao uso de seres humanos; porém, tal uso deve ser indispensável, imperativo e limitado a objetivos bem definidos.

2. importância da pesquisa para o ser humano - projetos de pesquisa envolvendo animais são essenciais e requeridos para atividades didáticas (ensino ou formação profissional) e experimentos científicos (testes de novas drogas ou estudo de doenças graves como tumores e imunodeficiências). Entretanto, deve-se enfatizar que nem tudo tecnicamente possível de ser realizado deve ser permitido e nem todos resultados obtidos em pesquisa com animais podem ser extrapolados ou aplicados por completo ao ser humano.

3. valorização e diferença entre as espécies - embora o ser humano seja, sem dúvida, mais importante que outros animais, estes também apresentam certo grau de importância - diferenciada segundo as várias espécies. Assim, em termos éticos, pare- 
ce haver um gradiente hierárquico na filogenia que preserva as espécies mais próximas do homem (como os macacos) em relação a espécies filogeneticamente mais distantes (como porcos, vacas ou roedores).

4. garantia de tratamento humanitário aos animais - durante os procedimentos de pesquisa deve-se impor limites à dor e ao sofrimento, incluindo analgesia, assepsia e eutanásia, bem como fornecer instalações e alimentação adequadas aos animais em experimentação.

5. avaliação de um comitê de ética - todo projeto de pesquisa envolvendo criação/utilização de animais deve ser analisado por um comitê de ética especializado na área de pesquisa em modelos animais, para qualificar ou aprovar os projetos e evitar o uso inapropriado ou abusivo de animais de experimentação.

\section{REGULAMENTAÇÕES E DIREITOS DOS ANIMAIS}

Em 1978, a UNESCO estabeleceu a Declaração Universal dos Direitos dos Animais, em Bruxelas, Bélgica, após abordar o assunto e tratar de temas que exigiam grandes discussões. No Brasil, em 1979, a lei 6.638/79, de 8/5/1979 - ainda não regulamentada por completo - estabeleceu as primeiras normas para a prática didático-científica da vivissecção de animais; a lei determina que só estabelecimentos de ensino de terceiro grau podem realizar atividades didáticas com animais, desde que não lhes provoquem sofrimento.

A lei 9.605 , de 12/2/1998, que trata de crimes ambientais (BRASIL, 1998), dispõe sobre sansões penais e administrativas derivadas de condutas e atividades lesivas ao meio ambiente, inclusive maus-tratos, e estabelece penalidades para experiências dolorosas ou cruéis em animais, mesmo com fins didático-científicos. A única menção ao uso de animais na resolução 196/96 (CONSELHO NACIONAL DE SAÚDE, 1996) - que contém as Diretrizes e Normas Regulamentadoras da Pesquisa Envolvendo Seres Humanos - refere-se à exigência de que as pesquisas envolvendo seres humanos sejam fundamentadas na experimentação prévia realizada em laboratórios, em animais ou em outros fatos científicos.

Assim, tem sido proposta a criação de comissões de ética para pesquisa em animais, como aquelas constituídas para pesquisa em seres humanos. Hoje grande parte das universidades e institutos de pesquisa nacionais dispõe de normas éticas e regimentos internos criados por essas comissões, dentre as quais, destacam-se: - Comissão de Ética em Experimentação Animal do Instituto de Ciências Biomédicas da Universidade de São Paulo (CEEA-ICB/ USP) — disponível no endereço eletrônico: <http//:www.fisio.icb.usp. 
br/posgraduaçao/etica/index_etica.htm>;

- Comissão de Ética em Experimentação Animal da Faculdade de Medicina de Ribeirão Preto da Universidade de São Paulo (CETEAFMRP/USP) - disponível no endereço eletrônico: <http//:www.fmrp. usp.br/ cetea/index.htm>;

- Comitê de Ética em Pesquisa da Universidade Federal de São Paulo/Escola Paulista de Medicina (CEA-UNIFESP/EPM) - disponível no endereço eletrônico: <http//:www.unifesp.br/reitoria/orgãos/ comites/etica.htm>;

- Comitê de Ética no Uso Animal do Instituto de Ciências Biológicas (IB) da Universidade de Brasília (CEUA-IB/UnB) - disponível no endereço eletrônico: <http//:www.unb.br/ib/etica.htm>;

- Comissão de Ética em Experimentação Animal do Instituto de Biologia e Biomédicas da Universidade do Estado de São Paulo, em Botucatu (CEEA-IBB/Unesp) - disponível no endereço eletrônico: <http//:www.ibb.unesp.br/comissoes/etica.htm>;

- Comissão de Ética em Experimentação Animal da Universidade Federal de Minas Gerais (CETEA-UFMG), disponível no endereço eletrônico: <http//:www.ufmg.br/cetea.htm>.

Em contrapartida, normas técnicas para o manejo de animais de laboratório podem ser encontradas no Manual para Técnicos em Bioterismo (DE LUCA, 1996) editado pelo Colégio Brasileiro de Experimentação Animal (COBEA). A adoção de normas internacionais tem sido comum em instituições de pesquisas brasileiras para implementar, quando necessário, as regulamentações nacionais. Por exemplo:

- Guide for the care and use of laboratory animals (NIH/OLAW/EUA); - Animal (scientific procedures) Act 1986 - Reino Unido;

- Animals used for experimental and other scientific purposes (1986)

- Council of Europe;

- Guide to the care and use of experimental animals (CCAC/Canadá);

- Report of the AVMA panel on euthanasia 2000 (JAVMA/EUA);

\section{PRINCÍPIOS ÉTICOS NA EXPERIMENTAÇÃO ANIMAL}

Os animais usados como modelos experimentais devem ser tratados com respeito e dignidade, pois integram uma população selecionada de animais da mesma espécie que está sendo privada da liberdade em favor da ciência. Assim, deve haver manejo adequado a cada espécie, que proporcione alojamento, cuidados veterinários, nutrição e transporte.

Os princípios éticos enumerados a seguir devem ser adotados em um projeto de pesquisa envolvendo modelos animais e adaptados segundo as normas do COBEA (1991) e os Princípios 
Internacionais para a Pesquisa Biomédica envolvendo Animais (CIOMS, Genebra, 1985).

1. Os pesquisadores e funcionários envolvidos no manejo de animais de experimentação devem ter qualificação e experiência comprovadas para exercer tal função. É preciso criar condições para o treinamento deles no trabalho, que inclua aspectos relativos ao respeito, ao trato e ao uso humanitário dos animais de laboratório.

2. Os projetos de pesquisa envolvendo animais devem ser realizados conforme a relevância para a saúde humana ou animal, a aquisição ou o avanço do conhecimento e o bem da sociedade. Deve-se demonstrar que o uso de animais é a única alternativa para se obterem os resultados desejados.

3. Os métodos alternativos à utilização de animais - como sistemas biológicos in vitro (cultura de células, tecidos), modelos matemáticos ou simulações em computador - devem ser priorizados quando possível.

4. A aquisição de animais para experimentação obedecerá à legislação nacional vigente e a políticas de conservação das espécies, sobretudo daquelas em extinção.

5. O uso de animais em procedimentos didáticos e experimentais pressupõe disponibilidade de alojamento e condições de vida adequadas às espécies e que contribuam para a saúde e o bemestar delas. O pesquisador e a instituição de pesquisa se responsabilizam por alojar adequadamente os animais - em biotério de experimentação ou local apropriado - e suprir necessidades de espaço físico, higiene, proteção contra predadores e necessidades ambientais (controle de ruídos; iluminação; odores; temperatura; umidade e ventilação). Instalações para quarentena e isolamento deverão estar disponíveis quando necessário.

6. Os animais em experimentação devem comer alimento peculiar a cada espécie, de boa procedência, em quantidade e qualidade apropriadas para garantir-lhes saúde e bem-estar, conforme as necessidades do experimento. $O$ fornecimento de água potável deve estar disponível e ser verificado todo dia.

7. Transporte, acomodação, alimentação, higiene e cuidados com os animais criados ou usados para fins biomédicos devem ficar a cargo de técnico qualificado.

8. Animais selecionados para experimentação devem ser de espécie apropriada, ter procedência e qualidade comprovadas e apresentar boas condições de saúde. Assim, o número de animais necessário para se obterem resultados válidos cientificamente pode ser minimizado graças à redução de perdas por mortalidade e estabelecido por cálculos estatísticos apropriados.

9. Os pesquisadores devem usar os animais para finalidades diversas sempre que possível, mas sem comprometer a qualidade 
científica dos experimentos.

10. Os pesquisadores envolvidos com experimentação animal devem ter consciência de que o animal tem sensibilidade similar à humana (no que se refere à angústia, dor e desconforto), memória e instinto de sobrevivência. Portanto, é imperativo que os animais sejam utilizados de maneira adequada.

11. Procedimentos que causem dor ou angústia nos animais devem ser acompanhados de sedação, analgesia ou anestesia adequadas à espécie. Atos cirúrgicos ou outros atos dolorosos não devem ser realizados em animais não anestesiados e paralisados por agentes químicos e físicos.

12. Os animais que sentirem dor ou angústia intensas ou crônicas que não podem ser aliviadas, ou aqueles sem condições físicas de continuar no experimento, devem ser sacrificados por método indolor e não estressante.

13. Nos experimentos em que a eutanásia for indicada, a morte dos animais deve ser realizada de forma rápida, indolor; seguir técnicas já consagradas e estar prevista e descrita no projeto de pesquisa.

14. Medidas de biossegurança devem ser adotadas para garantir proteção aos pesquisadores e funcionários envolvidos no manejo de animais utilizados em atividades didáticas ou em experimentação científica.

15. Todo pesquisador é moralmente responsável pelas escolhas que faz e pelos atos que realiza na experimentação animal.

\section{CONSIDERAÇÕES ESPECIAIS}

\section{Categoria dos experimentos}

Os experimentos envolvendo animais podem ser classificados com base nas seguintes categorias (adaptadas de CONSENSUS..., 1987):

(a) experimentos que não usam seres vivos ou que usam plantas, bactérias, protozoários ou espécies de animais invertebrados;

(b) experimentos com vertebrados que produza pequeno ou nenhum desconforto;

(c) experimentos que provocam estresse ou dor menor (dor de curta duração) em espécies de animais vertebrados;

(d) experimentos que provocam estresse ou dor significativos e inevitáveis em espécies de animais vertebrados (responsabilidade explícita de explorar alternativas);

(e) experimentos que provocam dor intensa, no ou acima do limiar de tolerância de animais conscientes não anestesiados (são consi- 
derados altamente questionáveis e muitos estão proibidos por algumas legislações).

\section{EXPERIMENTOS CONDENÁVEIS}

Alguns experimentos são condenáveis por provocarem intenso sofrimento físico ou psíquico. Incluem:

- privação prolongada de água e alimento;

- exposição ao calor ou frio excessivos;

- privação de sono ou descanso;

- provocação deliberada de pânico;

- choque elétrico;

- lesão traumática violenta;

- provocação de queimaduras;

- bloqueio da respiração ou circulação;

- privação prolongada de movimentos;

- mutilação grave.

\section{EUTANÁSIA}

A utilização de animais em atividades de ensino (técnicas anestésicas e cirúrgicas) e/ou pesquisa experimental tem suscitado vários questionamentos quanto à possibilidade de sofrimento e ao destino dos animais no fim das atividades experimentais ou didáticas. Muitas vezes, conforme os protocolos para experimentação animal, é preciso sacrificar os animais a fim de se obterem os resultados. Nessa situação, em geral o sacrifício não é contestado; mas o procedimento para tal deve ser adotado com critério para não fazer o animal sofrer ou se estressar.

Esse procedimento é denominado de eutanásia - do grego eu ("boa") e thanatos ("morte"), ou seja: "boa morte", aquela sem o mínimo de dor ou estresse. Assim, a eutanásia - a "morte humanitária" de um animal - pressupõe uso de métodos indolores que produzam inconsciência rápida, morte subseqüente (sem agonia e estresse) e sejam apropriados à idade e à espécie do animal. Dentre outros, os métodos podem ser físicos e químicos. Os físicos incluem concussão cerebral, deslocamento cervical, decapitação, choque elétrico - devem levar à perda imediata de consciência mediante trauma físico-cerebral e, em geral, são usados apenas quando o uso de drogas compromete os resultados da pesquisa; os químicos abrangem o uso de éter, clorofórmio e drogas anestésicas como barbituratos - têm de produzir a inconsciência e morte dos animais mediante superdosagem. Ambos objetivam a perda indolor da consciência, seguida de parada respiratória e cardíaca; o procedimento deve ser preciso e rápido, a fim de minimizar o estresse e abreviar 
a morte dos animais.

A eutanásia deve ser avaliada segundo perspectivas diferentes. Do ponto de vista:

- do animal, ela deve utilizar o mínimo de contenção, ser indolor, produzir inconsciência rápida e morte subseqüente;

- do executor, o método deve ser seguro e não provocar tensão emocional;

- da pesquisa, a eutanásia não deve produzir alterações biológicas ou histológicas para não comprometer os resultados;

- da instituição, ela deve ser economicamente viável no que se refere a equipamentos e locais apropriados.

Mesmo com todos esses critérios e conceitos, a eutanásia ainda sofre muitas críticas (vindas do meio científico, da sociedade e, sobretudo, das sociedades protetoras de animais - as quais questionam o caráter humanitário dos métodos e se, de fato, não provocam sofrimento), em especial se for realizada por indivíduos despreparados técnica e emocionalmente.

Os diferentes métodos de eutanásia usados em pesquisas, incluindo critérios e precauções referentes às diversas espécies animais, podem ser encontrados no Report of the AVMA panel on euthanasia, seqüência de publicações periodicamente atualizadas da revista científica Journal of the American Veterinary Medical Association (JAVMA). Tais procedimentos visam ao bem-estar do animal e orientam os comitês de ética em experimentação animal na maioria das universidades nacionais e internacionais (2000 REPORT..., 2001).

\section{Xenotransplantação}

Com a escassez mundial de doadores de órgãos, a tecnologia da xenotransplantação representa uma possibilidade de fornecer células, tecidos e órgãos vivos de outros primatas (espécies concordantes) e de não-primatas (espécies discordantes) a fim de transplantá-los para a espécie humana. Assim, o uso de pele de suínos e secções de vasos sanguíneos, devidamente tratados, em seres humanos tem sido bem-sucedido.

Entretanto, o uso de órgãos inteiros ainda traz sérias conseqüências por causa de problemas técnicos relativos, em especial, à segurança e eficiência do transplante. À parte isso, vários problemas éticos estão em discussão - e, por isso, sem regulamentação. Dentre eles, destacam-se:

- valorização da vida humana e vida animal;

- direito dos pacientes transplantados, expresso em termos de consentimento formal, e avaliação psicológica;

- intervenção governamental mediante leis sobre doação e recep- 
ção de órgãos vigentes em cada país;

- direito dos animais e a regulamentação da pesquisa em animais;

- riscos associados à transmissão de doenças zoonóticas ou mesmo xenozoonoses - doenças infecciosas provocadas por mutações que podem ocorrer na recombinação de vírus de diferentes espécies;

- resultados de estudos clínicos conduzidos em pacientes que receberam transplantes de órgãos de animais.

\section{Manipulação genÉtica}

Desde a década de 1980, a manipulação genética em animais revoluciona o conhecimento em todas as áreas da ciência (em particular na biomedicina e nas ciências biológicas) e a tecnologia - a transgênese - e os produtos - animais transgênicos dela derivados são difundidos no mundo como ferramentas essenciais à pesquisa em vários sistemas. Destacam-se como:

- modelo de diversas doenças humanas para investigação do funcionamento anormal e para testes de novas terapias;

- biorreatores capazes de produzir proteínas humanas com potencial uso médico;

- doadores de órgãos compatíveis com a espécie humana (xenotransplantação).

Entretanto, essa tecnologia tem ocasionado sérios problemas bioéticos relativos não só à própria espécie animal, mas também à humana. No primeiro caso, além da alteração deliberada das seqüências genéticas do hospedeiro, há grande descarte de animais produzidos cuja maioria é negativa para a alteração genética desejada (não-transgênicos). Noutras situações, há a possibilidade de alterações fisiológicas não esperadas em animais transgênicos - isto é, a possibilidade de grande sofrimento para o animal e mesmo de ele contrair doenças graves, a exemplo de tumores resultantes da inativação de um gene supressor de tumor.

Para os seres humanos, a transgênese representa o thin end of a wedge, ou seja, a possibilidade de a genética humana ser manipulada. Ao lado dos xenotransplantes envolvendo animais transgênicos, essa questão tem sido bastante discutida entre pesquisadores e a sociedade. Em resumo, a manipulação genética enfrenta objeções morais porque:

1. altera deliberadamente as seqüências genéticas do hospedeiro;

2. utiliza procedimentos invasivos para recuperar e transferir embriões;

3. ocasiona grande desperdício (morte) de animais;

4. pode provocar grande sofrimento aos animais e levar à manipulação genética de humanos. 
É lícito ressaltar, entretanto, que a contribuição da manipulação genética para o progresso científico e para a sociedade pode suplantar essas conseqüências negativas.

\section{CONCLUSÃo}

As pesquisas envolvendo animais datam de milhares de anos e, sem dúvida, têm contribuído muito para o desenvolvimento científico, sobretudo nas áreas da saúde humana e animal. Nos últimos anos, a ciência e a sociedade têm se unido para racionalizar o uso de animais em pesquisas, enfatizando valores morais, éticos e legais relativos à integridade e ao bem-estar da vida animal; o resultado disso é a criação de normas que prescrevem o uso de animais em pesquisa e são adotadas por diversas instituições científicas e órgãos governamentais. Nesse contexto, as comunidades científicas desempenham papel crucial e predominante entre líderes do governo no que se refere à implementação e regulamentação — pelo regimento interno - das normas de cuidados com animais destinados à pesquisa.

Os projetos de pesquisa com animais devem ser encaminhados a comitês de ética a fim de que estes avaliem os riscos e os benefícios - para o animal ou a sociedade. Embora não haja consenso sobre o status moral dos animais ou a posição que ocupam relativamente aos seres humanos, o respeito à vida dignifica o animal como merecedor de considerações éticas. Logo, todo pesquisador é moralmente responsável pelas escolhas e pelos atos atribuídos a ele na experimentação envolvendo animais.

\section{REFERÊNCIAS}

BRASIL. Lei n. 6.638/79 de 8 de maio de 1979 (lei ordinária). Estabelece normas para a prática didático-científica da vivissecção de animais e determina outras providências. Diário Oficial da União, Brasília, 10 maio de 1979. Coleção 2, p. 6.537.

. Lei no 9.605/98 de 12 de fevereiro de 1998 (Lei Ordinária). Dispõe sobre as sansões penais e administrativas derivadas de condutas e atividades lesivas ao meio ambiente e dá outras providências. Diário Oficial da União, Brasília, 13 fev. 1998. Seção I, p. 1.

. Ministério da Saúde. Conselho Nacional de Saúde. Diretrizes e normas regulamentadoras de pesquisa envolvendo seres humanos. Brasília,1997. 
. Ministério da Saúde. Conselho Nacional da Saúde. Resolução n. 251, de 5 de agosto de 1997. Cadernos de Ética em Pesquisa, n. 1, p. 43-46, jul. 1998.

COLÉGIO BRASILEIRO DE EXPERIMENTAÇÃO ANIMAL. Princípios éticos na experimentação animal. 1991. Disponível em: <http://www.univap.br/institutos/ipd/docs/principios_eticos_na_ experimentacao_animal.doc>. Acesso em: 10 maio 2005.

CONSELHO FEDERAL DE MEDICINA. Resolução n. 1.246, de 8 de janeiro de 1988. Estabelece a aprovação do Código de Ética Médica. Disponível em: <http://www.lampada.uerj.br/medlegal/ codetica.doc>. Acesso em: 10 maio 2005.

CONSELHO NACIONAL DE SAÚDE. Resolução n. 196 [de 10 de outubro de 1996]. Estabelece diretrizes e normas regulamentadora de pesquisa envolvendo seres humanos. Disponível em: <http:// www.bioetica.ufrgs.br/res19696.htm>. Acesso em: 10 maio 2005.

Resolução n. 251, de 7 de agosto de 1997. Regulamenta normas de pesquisa com novos fármacos, medicamentos, vacinas e testes diagnósticos envolvendo seres humanos. Disponível em: <http://www.bioetica.ufrgs.br/res25197.htm>. Acesso em: 10 maio 2005.

CONSENSUS Recommendations on Effective Institutional Animal Care and Use Committees. Laboratory Animal Science, Joliet, v. 37, p. 11-13, Jan. 1987. Special Issue.

DE LUCA, R. R. Manual para técnicos em bioterismo. 2. ed. São Paulo: USP/COBEA, 1996. 259p.

FLETCHER, R. H.; FLETCHER, S. W.; WAGNER, E. H. Epidemiologia clínica: elementos essenciais. 3. ed. Porto Alegre: Artes Médicas, 1996. 281p.

GORDIS, L. Epidemiology. Philadelphia: W. B. Saunders, 1996. JORGE, M. T.; RIBEIRO, L. A. Fundamentos para o conhecimento científico. São Paulo: Balieiro, 1999. 106p.

MELO, $\mathrm{H}$. et al. Ethical and legal issues in xenotransplantation. Bioethics, Oxford, v. 15, n. 5/6, p. 427-442, 2001.

MENEZES, H. S. Ética e pesquisa em animais. Revista AMRIGS, Porto Alegre, v. 46, n. 3/4, p. 105-108, 2002.

RAYMUNDO, M. M. Os Deveres dos pesquisadores para com os animais de experimentação: uma proposta de autoregulamentação. 2000. Dissertação (Mestrado em Fisiologia) Programa de Pós-graduação em Ciências Biológicas, Universidade Federal do Rio Grande do Sul, Porto alegre, 2000.

RAYMUNDO, M. M.; GOLDIM, J. R. Diretrizes para utilização de animais em experimentos científicos. Disponível em: <http:// 
www.bioetica.ufrgs.br/animdir.htm>. Acesso em: 10 maio 2005.

RUSSEL, W. M. S.; BURCH, R. L. The principles of humane experimental technique. London: Methuen and Company, 1959. (Reprint, Dover Publication and Potters Bar, UK; Universities Federation for Animal Welfare, 1992).

SINGER, P. Animal liberation. New York: Avon Books, 1991. 320p. SMITH, K. R. Animal genetic manipulation: a utilitarian response. Bioethics, Oxford, v. 16, n. 1, p. 55-71, 2002.

2000 REPORT of the AVMA panel on euthanasia. Journal of the American Veterinary Medicine Association, Schaumburg, v. 218, n. 5, p. 669-696, 2001.

UNESCO. Declaração universal dos direitos dos animais. Proclamada em sessão realizada em Bruxelas em 27 de janeiro de 1978. Disponível em: <http://www.interlegis.gov.br/cidadania/20020108 135443/20020205130509/view>. Acesso em: 10 maio 2005. 


\title{
MEDIDAS DE BIOSSEGURANÇA EM PESQUISA NA ÁREA BIOMÉDICA
}

\author{
José Roberto Mineo
}

\section{INTRODUÇÃO}

Laboratórios da área biomédica são, com freqüência, ambientes singulares de trabalho que podem expor as pessoas que neles atuam, ou estejam próximas a eles, a riscos de doenças infecciosas as mais diversas. As infecções contraídas em laboratório têm sido descritas por meio da história da microbiologia, cujos relatórios notificavam casos de brucelose, cólera, tétano e tifo associados com laboratórios já no início do século XX.

Nos dias atuais, as principais causas de acidentes em laboratórios incluem falta de orientação e ausência de equipamentos de proteção coletiva e individual, bem como a não-importância que se dá ao emprego de práticas de trabalho condizentes com o ambiente laboratorial. Tais práticas se resumem a uma série de normas e procedimentos de segurança que, quando bem utilizados, podem ajudar a evitar acidentes e aumentar a conscientização das pessoas que trabalham em laboratórios.

Neste capítulo, discutiremos os requisitos fundamentais à aquisição de conhecimentos básicos de biossegurança laboratorial para estudantes e profissionais. Buscamos aqui estimular o preparo de roteiros próprios de condutas gerais de segurança, os quais devem ser sempre atualizados e adequados para as diversas situações que se apresentam a todos que atuam em laboratórios biomédicos.

\section{PRINCÍPIOS DE BIOSSEGURANÇA}

O imprevisível e diversificado comportamento das doenças infecciosas emergentes e reemergentes tem fomentado a discussão das condições de biossegurança nas instituições de ensino, pesquisa, desenvolvimento tecnológico e de prestação de serviços. Não obstante o avanço tecnológico, o profissional de saúde está freqüen- 
temente exposto a riscos biológicos e de produtos químicos e agentes físicos, cujo enfrentamento está consubstanciado na adequação das instalações do ambiente de trabalho e na capacitação técnica desses profissionais. O manejo e a avaliação de riscos são fundamentais para a definição de critérios e de ações, e visam minimizar os riscos que podem comprometer a saúde do homem, dos animais, do meio ambiente ou a qualidade dos trabalhos desenvolvidos.

A biossegurança constitui uma área de conhecimento relativamente nova, regulada em vários países no mundo por um conjunto de leis, procedimentos ou diretrizes específicas. No Brasil, a legislação de biossegurança foi criada em 1995 e, apesar da grande incidência de doenças ocupacionais em profissionais de saúde, engloba apenas a tecnologia de engenharia genética, estabelecendo os requisitos para o manejo de organismos com modificação genética. A segurança dos laboratórios e dos métodos de trabalho transcende os aspectos éticos implícitos nas pesquisas com manipulação genética e, assim, exigem a adoção de medidas de biossegurança específicas pelos laboratórios, aliadas a um amplo plano de educação fundamentado em normas nacionais e internacionais quanto a transporte, conservação e manipulação de microorganismos patogênicos.

\section{MÉTODOS DE BIOSSEGURANÇA}

O termo "contenção" é usado para descrever os métodos de segurança utilizados na manipulação de materiais infecciosos em um meio laboratorial onde são manejados ou mantidos. O objetivo da contenção é reduzir ou eliminar a exposição da equipe de um laboratório, de outras pessoas e do meio ambiente em geral aos agentes com potencial patogênico. A contenção primária proteção da equipe do laboratório e do meio de trabalho contra a exposição aos agentes infecciosos - é proporcionada por uma boa técnica microbiológica e pelo uso de equipamento de segurança adequado e de vacinas, que podem fornecer elevado nível de proteção pessoal. A contenção secundária - proteção do meio ambiente externo ao laboratório contra a exposição aos materiais infecciosos - é proporcionada por um projeto de instalações que prevê as práticas operacionais.

Dessa forma, os três elementos de contenção incluem: 1) prática e técnica laboratorial; 2) equipamentos de segurança; e 3) projeto e construção das instalações. A avaliação do risco do trabaIho a ser realizado com um agente específico determinará a combinação adequada destes três elementos. 
1) Prática e técnica laboratorial - O elemento de contenção mais importante é a adesão rígida às práticas e técnicas microbiológicas padrão. As pessoas que trabalham com agentes infecciosos ou com materiais potencialmente contaminados devem se conscientizar dos possíveis riscos, ser treinadas e estarem aptas a lidar com técnicas e práticas necessárias ao manuseio seguro desses materiais. Cabe ao diretor ou à pessoa responsável pelo laboratório a responsabilidade pelo fornecimento ou pela elaboração de um treinamento adequado ao corpo de funcionários.

Cada laboratório deverá desenvolver ou adotar um manual de biossegurança que identifique os riscos que serão, ou poderão ser, encontrados e especifique as práticas e os procedimentos para minimizar ou eliminar a exposição a tais perigos. Os funcionários devem receber informações sobre os riscos especiais, bem como ler e seguir as práticas e os procedimentos solicitados. Um pesquisador treinado e com grande conhecimento das técnicas laboratoriais apropriadas, dos procedimentos de segurança e dos perigos associados ao manuseio de agentes infecciosos deve ser o responsável pela condução do trabalho envolvendo agentes ou materiais infecciosos.

Quando as práticas laboratoriais padrões não forem suficientes para controlar os perigos associados a um agente ou a um procedimento laboratorial em particular, medidas adicionais poderão ser necessárias. O diretor do laboratório será o responsável pela seleção das práticas adicionais de segurança, que devem estar relacionadas com os riscos associados aos agentes ou aos procedimentos. A ação da equipe, as práticas de segurança e as técnicas laboratoriais deverão ser complementadas por um projeto que considere a estrutura físico-arquitetônica, as instalações, os equipamentos de segurança e as práticas de gerenciamento.

2) Equipamentos de segurança (barreiras primárias) — Incluem cabines de segurança biológica (CSBs), recipientes adequados e outros controles da engenharia de segurança projetados para remover ou minimizar a exposição aos materiais biológicos infecciosos. A CSB é o dispositivo principal utilizado para a contenção de borrifos ou aerossóis infecciosos provocados por numerosos procedimentos microbiológicos.

Três tipos de cabines de segurança biológica (classes I, II e III) utilizados em laboratórios que manipulam agentes infecciosos serão descritos neste capítulo. As CSBs classes I e II, com a frente aberta, são barreiras primárias que oferecem níveis significativos de proteção para a equipe do laboratório e para o meio ambiente quando utilizadas com boas técnicas microbiológicas. A CSB Classe II também fornece uma proteção dos materiais que serão manipula- 
dos dentro das cabines (por exemplo, cultura de células, estoque microbiológico) contra a contaminação externa. A CSB Classe III, hermética e impermeável aos gases, proporciona o mais alto nível de proteção aos funcionários e ao meio ambiente.

Um outro exemplo de barreira primária é o copo de segurança da centrífuga, que é um recipiente conectado à centrífuga projetado para evitar que aerossóis sejam liberados durante a centrifugação. Para se minimizar esse risco, controles de contenção como as CSBs ou os copos deverão ser utilizados na lida com agentes infecciosos que possam ser transmitidos na exposição aos aerossóis.

$O$ equipamento de segurança também deve incluir itens para a proteção pessoal, tais como aventais, gorros e luvas; bota, proteção para sapatos; escudo ou protetor facial, máscaras faciais ou óculos de proteção, bem como respiradores. O equipamento de proteção pessoal, com freqüência, é utilizado em combinação com as CSBs e outros dispositivos para contenção de agentes, animais ou materiais que estão sob manipulação. Em alguns casos nos quais se torna impossível trabalhar em capelas de segurança biológica, o equipamento de segurança pessoal deve formar a barreira primária entre os trabalhadores e os materiais infecciosos. Os exemplos incluem certos estudos envolvendo animais, submetidos ou não a necropsias, ou atividades de produção em grande escala do agente infeccioso e atividades relacionadas com manutenção, serviços ou suporte da instalação do laboratório.

\section{3) Projeto e construção das instalações (barreiras secundárias)}

- O planejamento e a construção das instalações contribuem para a proteção da equipe do laboratório e proporcionam uma barreira de proteção, para quem se encontra fora do laboratório e para pessoas ou animais da comunidade, contra agentes infecciosos que podem ser liberados pelo laboratório por acidente. A gerência deve ser a responsável por instalações que estejam de acordo com o funcionamento do laboratório e com o nível de biossegurança recomendado para os agentes que forem ali manipulados.

As barreiras secundárias recomendadas dependerão do risco de transmissão dos agentes específicos. Por exemplo, o risco de exposição para grande parte dos trabalhos laboratoriais em dependências de um nível de biossegurança NB-1 e NB-2 - cujas definições serão discutidas mais adiante neste capítulo - será o contato direto com os agentes ou as exposições inadvertidas através de um ambiente de trabalho contaminado. As barreiras secundárias em tais laboratórios podem incluir isolamento da área de trabalho ao acesso público, disponibilidade de dependência para descontaminação (por exemplo, uma autoclave) e dependências para lavagem das mãos. 
Quando o risco de contaminação pela exposição aos aerossóis infecciosos estiver presente, níveis mais elevados de contenção primária e barreiras de proteção secundárias poderão ser necessários para se evitar que agentes infecciosos escapem para o meio ambiente. No projeto, tais características incluem sistemas de ventilação especializados em assegurar o fluxo de ar unidirecionado, sistemas de tratamento de ar para a descontaminação ou remoção do ar liberado, zonas de acesso controlado e câmaras pressurizadas como entradas de laboratório, separadas ou em módulos para isolamento. Os engenheiros responsáveis pelo projeto devem considerar as recomendações específicas para calefação, ventilação e refrigeração, como as de manuais que descrevem normas nacionais e internacionais.

\section{NÍVEIS DE BIOSSEGURANÇA}

Existem quatro níveis de biossegurança: NB-1, NB-2, NB3 e NB-4. São classificados, em ordem crescente, quanto ao maior grau de contenção e complexidade do nível de proteção. O nível de biossegurança de um experimento será determinado conforme o organismo de maior classe de risco envolvido no experimento. Quando não se conhece o potencial patogênico do organismo resultante, deverá ser feita uma análise detalhada e criteriosa de todas as condições experimentais.

Esses níveis se baseiam na combinação de práticas e técnicas laboratoriais, como também em equipamento de segurança e instalações. Cada combinação é adequada às operações realizadas, às vias de transmissão de agentes infecciosos documentadas ou suspeitas, bem como ao funcionamento ou à atividade do laboratório. Os níveis de biossegurança recomendados para cada grupo de organismos representam as condições nas quais o agente pode ser manuseado com segurança. O pesquisador principal do laboratório é, específica e primariamente, o responsável pela avaliação dos riscos e aplicação adequada dos níveis de biossegurança recomendados. Em geral, o trabalho com agentes desconhecidos deve ser conduzido em NB-3 ou NB-4.

Quando está disponível uma informação específica que possa sugerir a virulência, a patogenicidade, os padrões de resistência a antibióticos, a vacina e a disponibilidade de tratamento ou outros fatores significativamente alterados, práticas mais (ou menos) rígidas poderão ser adotadas. 


\section{Nivel de Biossegurança 1 (NB-1)}

As práticas, o equipamento de segurança e o projeto das instalações devem ser apropriados ao treinamento educacional secundário ou ao treinamento do pessoal envolvido em técnicas laboratoriais. Esse conjunto de medidas também é utilizado em outros laboratórios, onde é realizado o trabalho com cepas definidas e caracterizadas de microorganismos viáveis e conhecidos por não causarem doenças em indivíduos saudáveis. Bacillus subtilis, Naegleria gruberi, o vírus da hepatite canina infecciosa e organismos livres, de acordo com as Diretrizes de DNA Recombinantes do NIH (National Institute of Health - USA), são exemplos de microorganismos que preenchem todos os requisitos descritos acima. Muitos agentes que, em geral, não são associados com processos patológicos na espécie humana são, entretanto, patógenos oportunos e podem causar infecção em jovens, idosos e indivíduos imunodeprimidos. As cepas de vacina submetidas a múltiplas passagens in vivo não deverão ser consideradas avirulentas apenas porque são cepas de vacinas.

O NB-1 representa um nível básico de contenção que se baseia nas práticas padrão de microbiologia sem uma indicação de barreiras primárias ou secundárias, com exceção de uma pia para a higiene das mãos. Quanto às orientações exigidas para o NB-1, cabe enfatizar que:

1) o acesso ao laboratório deve ser limitado ou restrito de acordo com a definição do pesquisador principal, quando estiver sendo realizado o experimento;

2) as superfícies de trabalho devem ser descontaminadas uma vez ao dia ou sempre que ocorrer derramamento de material viável;

3) todo resíduo líquido ou sólido contaminado deve ser descontaminado antes de ser descartado, assim como todo material ou equipamento que tiver entrado em contato com o organismo;

4) deve-se utilizar dispositivo mecânico para pipetagem, pois é proibido pipetar com a boca;

5) é proibido comer, beber, fumar e aplicar cosméticos nas áreas de trabalho - alimentos devem ser guardados em áreas específicas para este fim fora do laboratório;

6) as mãos devem ser lavadas sempre que houver manipulação de organismos contendo DNA/RNA recombinante antes de se deixar o laboratório. Tendo em vista a prática de higiene pessoal, pias para lavagem das mãos e roupas para proteção (uniformes e jalecos) devem ser utilizadas para minimizar o risco de exposição aos organismos manipulados. 


\section{Práticas Laboratoriais especiais para NB-1}

Materiais contaminados só podem ser retirados do laboratório em recipientes rígidos e à prova de vazamentos. Deve ser providenciado um programa rotineiro de controle de insetos e roedores.

\section{Equipamentos de contenção exigidos para NB-1}

Em geral, para o NB-1 não são exigidos equipamentos de contenção para os agentes classificados no grupo de risco 1.

\section{Instalações Laboratoriais para NB-1}

O desenho do laboratório deve facilitar a limpeza e a descontaminação. É recomendável que a superfície das bancadas seja impermeável à água e resistente a ácidos, álcalis, solventes orgânicos e calor moderado. Os espaços entre bancadas, cabines e equipamentos devem permitir acesso fácil para se fazer a limpeza. Cada laboratório deve possuir uma pia para lavagem das mãos.

\section{Nivel de Bıossegurança 2 (NB-2)}

As práticas, os equipamentos, a planta e a construção das instalações são aplicáveis aos laboratórios clínicos, de diagnóstico, de pesquisa, laboratórios-escola e outros laboratórios onde o trabaIho é realizado com maior espectro de agentes nativos de risco moderado presentes na comunidade e que estejam associados a uma patologia humana de gravidade variável.

Embora esse nível seja semelhante ao NB-1 e adequado ao trabalho com agentes de risco moderado para as pessoas e o meio ambiente, eles se diferem nos seguintes aspectos:

1) o pessoal de laboratório deve ter treinamento técnico específico para manejar agentes patogênicos e ser supervisionado por pesquisadores competentes;

2) o acesso ao laboratório deve ser limitado durante os procedimentos operacionais;

3) determinados procedimentos nos quais haja possibilidade de formação de aerossóis infecciosos devem ser conduzidos em cabines de segurança biológica ou em outro equipamento de contenção física.

Com boas técnicas microbiológicas, esses agentes podem ser usados de maneira segura em atividades conduzidas sobre uma bancada aberta, pois o potencial para produção de borrifos e 
aerossóis é baixo. Os vírus da hepatite $B$ e da imunodeficiência humana (HIV), Salmonella spp., Leishmania spp., Trypanosoma cruzi e Toxoplasma gondii são exemplos de microorganismos designados como agentes de risco 2 .

O NB-2 é adequado para qualquer trabalho que envolva sangue humano, líquidos corporais, tecidos ou linhagens de células humanas primárias onde a presença de um agente infeccioso pode ser desconhecida. Os laboratoristas que trabalham com materiais humanos devem consultar o livro Padrão de patógenos transmitidos pelo sangue (OSHA bloodborne pathogen standard) para as precauções específicas necessárias.

Os laboratórios clínicos, em especial aqueles situados em clínicas e hospitais, recebem amostras biológicas requisitando grande variedade de diagnósticos e serviços de apoio clínico. Em geral, a natureza infecciosa do material clínico é desconhecida, e as amostras são freqüentemente submetidas a uma ampla solicitação de exame microbiológico em relação aos múltiplos agentes (por exemplo, o escarro pode ser submetido a uma cultura de "rotina" ácido resistente e uma cultura fúngica).

Cabe ao responsável pelo laboratório padronizar procedimentos laboratoriais que, de fato, direcionem a questão do perigo da infecção imposto pelas amostras clínicas. Exceto em circunstâncias extraordinárias (como suspeita de febre hemorrágica), o processamento inicial de uma amostra clínica e a identificação sorológica de substâncias isoladas poderão ser realizados de forma segura em um NB-2 - recomendado para o trabalho com patógenos do sangue como o vírus da hepatite $\mathrm{B}$ e o HIV.

As recomendações para o NB-2 enfocam a prevenção à exposição, por contato, da pele e das mucosas aos materiais clínicos. Barreiras primárias como as CSBs (classes I e II) devem ser usadas em procedimentos que causam gotejamento, pulverização e salpicos de gotas. As CSBs também devem ser usadas no início da manipulação de espécimes clínicos se a natureza do teste requerer, ou em presença de um agente que, reconhecidamente, transmite infecções por aerossóis (por exemplo, Micobacterium tuberculosis), ou ainda quando o uso de uma CSB classe II é indicado para proteger a integridade do espécime.

A compartimentalização das funções de um laboratório clínico e acesso limitado ou restrito a tais áreas são de responsabilidade do diretor da instituição; também cabe a ele estabelecer um padrão e procedimentos - por escrito - que direcionem os riscos potenciais e os cuidados ou as precauções necessárias a serem implantadas.

Os perigos primários em relação aos funcionários que trabalham com esses agentes estão relacionados com acidentes percutâneos, exposição da membrana mucosa ou ingestão de ma- 
teriais infecciosos. Deve-se tomar extremo cuidado com agulhas contaminadas ou com instrumentos cortantes. Embora os organismos rotineiramente manipulados em um NB-2 não sejam transmitidos por meio de aerossóis, os procedimentos envolvendo alto potencial para a produção de aerossóis que possam aumentar o risco de exposição desses funcionários devem ser conduzidos com um equipamento de contenção primária ou com dispositivos como a CSB ou os copos de segurança da centrífuga.

Outras barreiras primárias como escudos para borrifos, proteção facial, aventais e luvas devem ser utilizadas de maneira adequada. Barreiras secundárias, como pias para se fazer a higiene das mãos e instalações para descontaminação de lixo, devem ter a finalidade de reduzir a contaminação potencial do meio ambiente.

\section{Práticas microbiológicas exigidas para NB-2}

As práticas microbiológicas exigidas para o NB-2 são as mesmas já descritas para o NB-1.

\section{Práticas especiais para NB-2}

Além das práticas especiais descritas para o NB-1, devem ser incluídas para o NB-2 as práticas discriminadas a seguir.

- O pesquisador principal tem a responsabilidade de limitar o acesso ao laboratório;

- O pesquisador principal deve estabelecer políticas e procedimentos com ampla informação a todos que trabalhem no laboratório sobre o potencial de risco relacionado ao trabalho, bem como sobre os requisitos específicos para entrada em laboratório e em salas onde ocorra manipulação de animais;

- No interior do laboratório, os freqüentadores devem utilizar roupas apropriadas, tais como jalecos, gorros, máscaras, etc., antes de saírem do laboratório para áreas externas (biblioteca, cantina, escritório administrativo); eles devem retirar a roupa protetora e deixá-la no laboratório;

- Quando organismos contendo moléculas de DNA/RNA recombinantes estiverem sob manipulação, são exigidos requisitos especiais para a entrada de pessoal no laboratório (por exemplo, a vacinação). Deve ser colocado um aviso para sinalizar o risco, identificando o agente e o nome do pesquisador principal, endereço completo e diferentes possibilidades de sua localização ou de outra pessoa responsável. Todos os requisitos necessários à entrada no laboratório devem estar assinalados na porta de entrada;

- É proibida a admissão de animais que não estejam relacionados ao trabalho em execução no laboratório. Cuidados especiais 
devem ser tomados para impedir contaminação da pele com organismos contendo moléculas de DNA/RNA recombinantes; devem ser usadas luvas no manejo de animais em experimentação e sempre que houver possibilidade de contato da pele com o organismo geneticamente modificado. Todo lixo de laboratório e da sala de animais deve ser adequadamente descontaminado antes de ser descartado;

- Agulhas e seringas hipodérmicas devem ser usadas somente para inoculação parenteral e aspiração de fluidos de animais de laboratório e garrafas de diafragmas. Devem ser usadas apenas seringas com agulha fixa ou agulha e seringa em uma unidade apenas nas atividades de injeção ou aspiração de fluidos contendo moléculas de DNA/RNA recombinantes. Extrema precaução deve ser tomada quando houver manuseio de agulhas e seringas para se evitarem auto-inoculação e produção de aerossóis durante o uso e o descarte. As agulhas não devem ser entortadas, quebradas, recapeadas ou removidas da seringa após o uso. Agulha e seringa devem ser imediatamente colocadas em recipiente resistente à prova de perfurações e descontaminados autoclavados, de preferência - antes do descarte. Desaconselhase a reutilização de seringas;

- Derramamentos ou acidentes que resultem em exposição a organismo contendo moléculas de DNA/RNA recombinante devem ser imediatamente notificados às comissões institucional e nacional de biossegurança (CIBio e CTNBio, respectivamente), com providências de avaliação médica, vigilância e tratamento, bem como registro dos acidentes e das providências adotadas;

- Dependendo do agente manipulado, quando for apropriado e para referência futura, devem ser mantidas amostras-referência de soro do pessoal do laboratório ou de outras pessoas possivelmente expostas ao risco, inclusive pessoal de limpeza e de manutenção. Amostras adicionais de soro devem ser colhidas periodicamente, dependendo do agente manipulado ou em função das instalações laboratoriais. Um manual de biossegurança deve ser preparado de acordo com as especificidades das atividades realizadas. Todo o pessoal deve ser orientado sobre os possíveis riscos e para a necessidade de seguir as especificações de cada rotina de trabalho, procedimentos de biossegurança e práticas estabelecidas no manual.

\section{Equipamentos de contenção exigidos para NB-2}

Devem ser utilizadas CSBs classes I ou II ou outro dispositivo de contenção pessoal ou dispositivos de contenção física quando: 
- forem realizados procedimentos com elevado potencial de criação de aerossóis, como centrifugação, trituração, homogeneização, agitação vigorosa, ruptura por sonicação, abertura de recipientes contendo material onde a pressão interna possa ser diferente da pressão ambiental, inoculação intranasal em animais e em cultura de tecidos infectados;

- houver altas concentrações ou grandes volumes de organismos contendo DNA/RNA recombinante - tais materiais só poderão ser centrifugados fora de cabines de segurança se for em centrífugas de segurança e com frascos lacrados, que deverão ser abertos apenas no interior da cabine de segurança biológica.

\section{Instalações laboratoriais para NB-2}

As instalações laboratoriais exigidas para o NB-2 devem atender às especificações estabelecidas para o NB-1, acrescidas da seguinte exigência: uma autoclave deve estar disponível no interior ou próximo ao laboratório para permitir a descontaminação de todo o material antes do descarte.

\section{Nivel de Biossegurança 3 (NB-3)}

As práticas, o equipamento de segurança, o planejamento e construção das dependências são aplicáveis para laboratórios clínicos, de diagnósticos, laboratórios-escola, de pesquisa ou de produções. Isso porque, nesses locais, trabalha-se com agentes nativos ou exóticos que possuem potencial de transmissão por via respiratória e que podem provocar infecções sérias e potencialmente fatais. M. tuberculosis, o vírus da encefalite de St. Louis e Coxiella burnetii são exemplos de microorganismos determinados para esse nível. Os riscos primários causados aos trabalhadores que lidam com esses agentes incluem auto-inoculação, ingestão e exposição aos aerossóis infecciosos.

No NB-3, devem ser enfatizadas as barreiras primárias e secundárias para a proteção de funcionários de áreas contíguas, da comunidade e do meio ambiente contra a exposição aos aerossóis infecciosos. Por exemplo, todas as manipulações laboratoriais deverão ser realizadas em uma CSB ou em outro equipamento de contenção, como câmara hermética de geração de aerossóis. As barreiras secundárias para esse nível incluem acesso controlado ao laboratório e sistemas de ventilação que minimizem a liberação de aerossóis infecciosos do laboratório.

Essas normas devem ser aplicadas em todos os locais onde forem desenvolvidos trabalhos com agentes infecciosos que possam causar doenças sérias e potencialmente letais como resultado 
de exposição por inalação. O pessoal do laboratório deve ter treinamento específico para manejar agentes patogênicos e letais e deve ser supervisionado por profissionais com vasta experiência com tais agentes. Todos os procedimentos que envolverem a manipulação de material infeccioso devem ser conduzidos dentro de cabines de segurança biológica ou de outro dispositivo de contenção física, e os manipuladores devem usar roupas de proteção individual. $O$ laboratório deverá ter instalações compatíveis para o NB-3.

Para alguns casos, quando não existirem as condições específicas para o NB-3, particularmente em instalações laboratoriais sem área de acesso específica, ambientes selados ou fluxo de ar unidirecional, as atividades de rotina e operações repetitivas podem ser realizadas em laboratório com instalações NB-2, acrescidas das práticas recomendadas para NB-3 e do uso de equipamentos de contenção para NB-3. Cabe ao pesquisador principal a decisão de implementar essas modificações e informá-las à CIBio e à CTNBio.

\section{Práticas microbiológicas exigidas para NB-3}

Além das práticas microbiológicas estabelecidas para o NB2 , o trabalho com agentes de risco 3 exige que menores de 18 anos de idade não entrem no laboratório. Se forem realizados experimentos com agentes que exigirem nível de contenção inferior a NB-3, eles devem ser conduzidos de acordo com as práticas laboratoriais estabelecidas para o NB-2.

\section{Práticas laboratoriais especiais para NB-3}

Além das práticas estabelecidas para o NB-2, devem ser obedecidas para o NB-3 as práticas discriminadas a seguir.

- As superfícies de trabalho das cabines de segurança e de outros equipamentos de contenção devem ser descontaminadas sempre ao término do trabalho com moléculas de DNA/RNA recombinantes. Toalhas absorventes com uma face de plástico voltada para baixo, recobrindo as superfícies das bancadas, facilitam o trabalho de limpeza;

- Deve ser usado uniforme completo específico para áreas de trabaIho com organismos geneticamente modificados, mas é proibido o uso fora do laboratório. As roupas devem ser descontaminadas antes de serem encaminhadas à lavanderia ou para descarte;

- Devem ser utilizadas máscaras faciais apropriadas ou respiradores nas salas onde são manipulados animais de experimentação;

- Animais de laboratório em NB-3 devem ser mantidos em sistemas de confinamento parcial (sistemas de caixas com filtros e paredes 
rígidas ou sistemas de contenção de caixas equipados com radiação ultravioleta e refletores). Os sistemas convencionais de caixas só poderão ser usados quando todo o pessoal utilizar dispositivos e roupas protetoras, os quais devem incluir roupa completa do tipo escafandro e respiradores. Todo o pessoal deverá tomar banho ao deixar essas áreas de trabalho. As linhas de vácuo devem estar protegidas com filtro de ar com elevada eficiência (filtros do tipo High Efficiency Particulated Air/HEPA) e coletores com líquido desinfetante.

\section{Equipamentos de contenção exigidos para NB-3}

Cabines de segurança biológica (classes I, II ou III), ou outra combinação apropriada de dispositivos de proteção pessoal e contenção física, devem ser usadas em qualquer operação com microorganismos geneticamente modificados, em que se incluem manipulação de culturas e material clínico ou ambiental, operações de desafio de animais, cultivo de tecidos ou fluidos infectados de animais em experimentação ou ovos embrionados, bem como necropsia de animais em experimentação.

\section{Instalações laboratoriais para NB-3}

- O laboratório deverá estar separado das áreas de trânsito irrestrito do prédio;

- É exigido um sistema de dupla porta como requisito básico para entrada no laboratório pelos corredores de acesso ou para outras áreas contíguas;

- A separação física de laboratórios de elevada contenção dos demais ou dos corredores de acesso pode ser por sistema de dupla porta, com sala para troca de roupas, chuveiros, bloqueio de ar e outros dispositivos para acesso em duas etapas;

- A superfície das paredes internas, o piso e o teto devem ser resistentes à água, a fim de permitir acesso fácil para o caso de limpeza;

- Toda a superfície deve ser selada e não ter reentrâncias para facilitar limpeza e descontaminação;

- As superfícies das bancadas devem ser impermeáveis à água e resistentes a ácidos, álcalis, solventes orgânicos e calor moderado;

- O mobiliário do laboratório deve ser rígido, com espaçamentos entre bancadas, cabines e equipamentos para facilitar o acesso em caso de limpezal;

- Próximo à porta de saída, cada laboratório deverá ter, pelo menos, uma pia para lavagem das mãos, com torneira de acionamento automático ou com sistema de pedais;

- As janelas do laboratório devem ser fechadas ou lacradas; 
- As portas de acesso ao laboratório ou ao módulo de contenção devem ter fechamento automático;

- Deve haver autoclave para a descontaminação de resíduos no interior do laboratório ou em área contígua, de preferência com sistema de dupla porta;

- O laboratório deve ter um sistema de ar independente, com ventilação unidirecional, em que o fluxo de ar penetre no laboratório pela área de entrada. Não deverá haver exaustão do ar para outras áreas do prédio; o ar de exaustão não deve, portanto, circular de novo e, antes de ser eliminado, terá de ser filtrado com filtro HEPA;

- Deve haver verificação constante do fluxo de ar no laboratório. O ar de saída das CSBs com filtros HEPA de elevada eficiência (classe I ou classe II) deve ser expelido diretamente para fora do edifício por sistema de exaustão. $\mathrm{O}$ ar de saída das cabines pode recircular no interior do laboratório se a cabine for testada e certificada anualmente.

\section{Nivel de Biossegurança 4 (NB-4)}

As práticas, o equipamento de segurança, o planejamento e a construção das dependências em um NB-4 são aplicáveis para trabalhos que envolvam agentes exóticos perigosos e representam alto risco, por provocarem doenças fatais em indivíduos. Tais agentes podem ser transmitidos via aerossóis e, até o momento, não há nenhuma vacina ou terapia disponível. Os que têm relação antigênica próxima ou idêntica à dos agentes do NB-4, também, deverão ser manuseados nesse nível. À medida que se acumulam dados suficientes sobre a biologia de tais agentes, o trabalho com os microorganismos deve continuar nesse nível ou em nível inferior. Vírus como os de Marburg ou da febre hemorrágica Criméia-Congo são manipulados no NB-4.

Os riscos primários aos trabalhadores que manuseiam agentes do NB-4 incluem exposição respiratória aos aerossóis infecciosos, exposição da membrana mucosa e/ou da pele lesionada a gotículas infecciosas e auto-inoculação. Toda a manipulação de materiais de diagnóstico potencialmente infecciosos, substâncias isoladas e animais natural ou experimentalmente infectados apresentam alto risco de exposição e infecção aos funcionários de laboratório, à comunidade e ao meio ambiente. O completo isolamento dos trabalhadores de laboratórios em relação aos materiais infecciosos aerossolizados é feito primariamente em CSB classe III ou com macacão individual suprido com pressão de ar positivo.

A instalação do NB-4 é, em geral, construída em um prédio separado ou em zona isolada por completo, com ventilação comple- 
xa e especializada e sistemas de gerenciamento de lixo que evitem liberação de agentes viáveis no meio ambiente.

O diretor do laboratório é primária e especificamente a pessoa responsável pela operação segura do laboratório. O conhecimento e julgamento dele/dela são críticos para avaliação de riscos e aplicação adequada dessas recomendações. O nível de biossegurança indicado representa condições sob as quais o agente pode ser manipulado com segurança. As características especiais dos agentes utilizados, o treinamento e a experiência do pessoal envolvido, como também a natureza da função do laboratório, poderão influenciar o diretor posteriormente quanto à aplicação das recomendações mais adequadas.

O nível de contenção NB-4 deve ser usado sempre que o trabalho envolver organismos com modificação genética resultantes de organismos receptores ou parentais classificados como classe de risco 4, ou sempre que envolver organismo receptor, parental ou doador com potencial patogênico desconhecido.

\section{Práticas laboratoriais especiais para NB-4}

Devem ser obedecidas as práticas especiais estabelecidas para o NB-3, acrescidas das exigências especificadas a seguir. - Nenhum material deverá ser removido do laboratório de contenção máxima, a menos que tenha sido autoclavado ou descontaminado - exceção feita aos materiais biológicos que tenham de ser retirados na forma viável ou intacta;

- Suprimentos e materiais a serem usados no laboratório devem ser descontaminados em autoclave de dupla porta, câmara de fumigação ou sistema de antecâmara pressurizada;

- O material biológico viável a ser removido de cabines do tipo classe III ou do laboratório de contenção deve ser acondicionado em recipiente de contenção inquebrável e selado; este, por sua vez, deverá ser acondicionado em um segundo recipiente - também inquebrável e selado - que passe por um tanque de imersão com desinfetante ou por câmara de fumigação ou, ainda, por sistema de barreira de ar;

- Equipamentos ou materiais que não resistam a temperaturas elevadas devem ser descontaminados por meio de gases ou vapor em câmara específica;

- Só quem trabalha no laboratório deve ter permissão para entrar. $O$ pesquisador principal tem a responsabilidade final de controlar o acesso, que, por questão de segurança, deve ser bloqueado por portas hermeticamente fechadas. A entrada deve ser controlada pelo pesquisador principal ou por alguém responsável pela segurança do prédio; 
- Antes de adentrar o laboratório, as pessoas precisam ser avisadas sobre o risco potencial e instruídas quanto às medidas de segurança apropriadas. As pessoas autorizadas devem cumprir, com rigor, as instruções de procedimento para entrada e saída do laboratório. Deve haver registro por escrito, com data, horário e assinatura de quem entra e de quem sai;

- Devem ser definidos protocolos para situações de emergência. Entrada e saída de pessoal do laboratório devem ocorrer só após uso do chuveiro e a troca de roupa. A entrada e a saída de pessoal por antecâmara pressurizada apenas deve ocorrer em situações de emergência. Para adentrar o laboratório, a roupa comum, de rua, deve ser trocada por roupa protetora completa e descartável. Antes da saída do laboratório para a área de banho, a roupa protetora deve ser deixada em área específica para descontaminação antes do descarte;

- Deve ser organizado sistema de notificação de acidentes, exposição e absenteísmo do pessoal do laboratório, bem como sistema de vigilância médica. Deve-se ainda prever uma unidade de quarentena, isolamento e cuidados médicos para o pessoal suspeito de contaminação.

\section{Equipamentos de contenção exigidos para NB-4}

A manipulação com agentes de risco 4 conduzida no laboratório deve ser realizada em CSB classe III, ou classes I ou II - usadas, nesse caso, em associação com roupas de proteção pessoal, com pressão positiva e ventiladas por sistema de suporte de vida.

\section{Instalações laboratoriais para NB-4}

- A unidade de contenção máxima deve estar localizada em prédio separado ou em área claramente demarcada e isolada do edifício;

- Devem ser previstas câmaras de entrada e saída de pessoal separadas por chuveiro. Deve ser previsto sistema de autoclave de dupla porta, câmara de fumigação ou sistema de ventilação com antecâmara pressurizada para o fluxo de materiais para o interior do laboratório;

- Paredes, teto e piso do laboratório devem ser construídos com sistema de vedação interna para permitir maior eficiência da fumigação e evitar o acesso de animais e insetos. As superfícies internas do laboratório devem ser resistentes a líquidos e produtos químicos;

- O sistema de drenagem do solo deve conter depósito com desinfetante químico eficaz para o agente em questão, conectado diretamente a um sistema coletor de descontaminação de líquidos. $O$ 
sistema de esgoto e de ventilação deve estar acoplado a filtros HEPA de elevada eficiência. O sistema de suprimento de luz, os dutos de ar e as linhas utilitárias devem, de preferência, estar posicionados na vertical para se evitar o acúmulo de poeira;

- A descontaminação de material deve ser feita por meio de sistema de autoclave de dupla porta com controle automático, para permitir a retirada de material pelo lado oposto. Materiais e equipamentos que não possam ser descontaminados na autoclave devem passar por tanque de imersão com desinfetante ou por câmara de fumigação. O líquido efluente, antes de ser liberado do laboratório, deve ser descontaminado com tratamento por calor. Os líquidos liberados por chuveiros ou sanitários devem ser descontaminados com produtos químicos ou pelo calor;

- O sistema de ar no laboratório deve prever pressão diferencial e fluxo unidirecional, de modo a assegurar diferencial de pressão que não permita a saída do agente de risco. No sistema de ar, devem estar acoplados manômetros, com sistema de alarme, que acusem alteração sofrida no nível de pressão exigido para as diferentes salas;

- O sistema de exaustão deverá estar acoplado a filtros HEPA de elevada eficiência. O ar liberado pelas CSBs classes I e II pode ser descartado para dentro ou fora do ambiente do laboratório, desde que, no sistema de exaustão, haja filtros HEPA acoplados. A cada seis meses, as cabines biológicas devem ser testadas e certificadas. A exaustão de ar das cabines classe III deve ser realizada sem recirculação, por meio de sistema de dupla filtragem, com filtros HEPA em série, no sistema de exaustão do laboratório;

- O laboratório deve ter local para o pessoal vestir roupas específicas com pressão positiva e sistema de suporte de vida. O sistema deve prever alarmes e tanques de respiração de emergência;

- O laboratório deve ter chuveiro para descontaminar quimicamente as superfícies da roupa antes da saída da área. $O$ ar deve ser insuflado através de filtros HEPA e expelido para o exterior por meio de dutos de exaustão - cada um com dois filtros HEPA colocados em série e com alternância de circuito de exaustão automatizado. A entrada de ar de insuflamento deverá estar protegida com filtro HEPA. Deve haver um sistema de descontaminação, com autoclave de dupla porta. As instalações de filtros e esgotos devem estar confinados à área de contenção.

\section{CABINES DE SEGURANÇA BIOLÓGICA}

As cabines de segurança biológica estão entre os mais comuns e eficazes dispositivos de contenção primária utilizados em 
laboratórios que trabalham com agentes infecciosos. Os três tipos gerais de cabines (classes I, II e III) possuem características e aplicações que serão descritas a seguir.

As CSBs classes I e II, adequadamente mantidas e usadas em conjunto com boas técnicas microbiológicas, proporcionam um sistema de contenção eficaz para manipulação segura de microorganismos de risco moderado ou alto (agentes do NB-2 e NB-3). Tanto as CSBs classe I como as classe II têm velocidade de fluxo de ar (75-100 pés lineares por minuto) que proporcionam níveis de contenção comparáveis à proteção de funcionários do laboratório e do meio ambiente das áreas adjacentes contra aerossóis infecciosos gerados dentro das cabines. As CSBs classe II, também, protegem o próprio material e a pesquisa, através de uma filtração altamente eficiente - filtração HEPA — do fluxo de ar sobre toda a superfície de trabalho (fluxo laminar vertical). Já as CSBs classe III oferecem proteção máxima para os trabalhadores do laboratório, a comunidade e o meio ambiente porque todos os materiais perigosos estão contidos em uma cabine ventilada e toda fechada. Uma comparação entre as principais características das CSBs classes I, II e III está demonstrada no Quadro 4.1.

\section{CSB Classe I}

As CSBs classe I (Figura 4.1) são cabines ventiladas de pressão negativa, operadas por abertura frontal e mínima velocidade de face para abertura de trabalho de 75 pés lineares por minuto (Ifpm). Todo o ar da cabine é liberado por um filtro HEPA para dentro ou para fora do laboratório. Atualmente, as cabines classe I são fabricadas em número limitado; muitas podem ser substituídas por cabines classe II.

A cabine classe lé projetada para pesquisa geral de agentes microbiológicos de risco moderado e baixo e é útil para contenção de processadores, liquidificadores e outros equipamentos. Tais cabines não são apropriadas à manipulação de materiais de pesquisa vulneráveis à contaminação pelo ar, pois o fluxo interno do ar não filtrado do laboratório pode carregar microorganismos contaminantes para dentro da cabine.

A CSB classe I pode, também, ser usada com um painel frontal fechado e sem as luvas de borracha, o que aumentará a velocidade do fluxo interno para quase $150 \mathrm{lfpm}$. Se essas cabines equipadas estiverem ligadas por dutos externos de exaustão, elas poderão ser usadas para materiais tóxicos ou com baixos níveis radioativos usados como auxiliares da pesquisa microbiológica. Além disso, as luvas de braços longos de borracha podem ser anexadas ao painel frontal com um dispositivo de liberação da pressão 
do ar para maior proteção. Nessa configuração, é necessário instalar entrada de ar adaptada e ajustada com um filtro HEPA na cabine.

\section{CSB Classe II}

A CSB classe II (Figura 4.2) é projetada com um fluxo de ar interior com velocidade (75-100 lfpm) para proteger os funcionários e outro fluxo de ar laminar vertical filtrado pelo sistema HEPA para proteção do produto, com o ar de saída (exaustão) filtrado pelo sistema HEPA para proteção do meio ambiente.

Os padrões do projeto, a construção e a atuação das cabines classe II, assim como as listas de produtos que atendam a esses padrões, foram desenvolvidos pela National Sanitation Foundation International, em Ann Arbor, Michigan, EUA. A utilização desse padrão e dessa lista deverá ser o primeiro passo na seleção e aquisição de uma cabine classe II.

As CSBs classe II são classificadas em dois tipos (A e B) com base na construção, nas velocidades, nos padrões do fluxo de ar e nos sistemas de exaustão. Em essência, as cabines tipo A (Figura 4.2a) são adequadas a pesquisas microbiológicas na ausência de substâncias químicas voláteis ou tóxicas e de radionuclídeos, pois o ar é recirculado dentro da cabine; e podem ter exaustão dentro do laboratório ou para fora, através de uma conexão metálica que se prende ao sistema de exaustores do edifício.

As cabines tipo B são subdivididas em B1, B2 e B3. Uma comparação entre as características do projeto e as aplicações está representada nas figuras $4.2 \mathrm{~b}, 4.2 \mathrm{c}$ e $4.2 \mathrm{~d}$, respectivamente. Essas cabines têm dutos rígidos conectados ao sistema de exaustão do prédio e contêm um sistema de ar de pressão negativa. Tais características, mais velocidade plena de 100 lfpm, permitem que o trabalho seja feito com substâncias químicas tóxicas ou radionuclídeos.

É essencial que as CSBs classes I e II sejam testadas e certificadas in situ no momento da instalação no laboratório, todas as vezes que a CSB for removida, ou uma vez ao ano. A verificação local pode atestar o desempenho da cabine individual ou modelo, mas não poderá excluir os testes críticos antes do uso em laboratório. Como todo equipamento laboratorial, as pessoas deverão ser treinadas para usar as cabines de segurança biológica.

De particular interesse são as atividades que possam romper o fluxo direcionado para o interior. Fatores como inserção e retirada repetida dos braços de trabalhadores para dentro e para fora das cabines; abertura e fechamento de portas do laboratório ou do cubículo de isolamento; colocação ou operação imprópria dos materiais ou dos equipamentos na câmara de trabalho ou uma caminhada vigorosa próxima à CSB enquanto esta estiver em uso 
provocam a liberação dessas partículas aerolizadas de dentro da cabine.

As CSBs classes I e II deverão estar localizadas longe do fluxo de pessoas e de portas. O fluxo de ar gerado por ventiladores e a ventilação proveniente de venezianas para movimentação do ar podem interromper o padrão de fluxo de ar na frente da cabine. A obediência rigorosa a essas regras para uso das CSBs e o posicionamento adequado destas no laboratório são tão importantes à manutenção da capacidade de contenção máxima do equipamento quanto o próprio funcionamento deste.

\section{CSB CLAsSE III}

A CSB classe III (Figura 4.3) é uma cabine toda fechada e ventilada, à prova de escape de ar. Oferece o mais alto grau de proteção aos profissionais que nela atuam e ao meio ambiente contra aerossóis infecciosos; protege também os materiais de pesquisa de contaminantes microbiológicos. As CSBs classe III são mais adequadas para o trabalho com agentes perigosos que requeiram contenção de NB-3 ou NB-4. As operações na área e o trabalho da cabine deverão ser realizados por braços com luvas de borracha ou protegidos por um macacão. A CSB classe III é operada com pressão negativa; o suprimento de ar é filtrado pelo sistema HEPA, e o ar liberado da cabine é filtrado por dois filtros HEPA em série; ou a filtração HEPA é seguida de uma incineração antes de o ar ser descartado para fora do local. Os equipamentos necessários a atividades em laboratório - dentre outros, incubadoras, geladeiras e centrífugas - deverão ser parte integral do sistema de cabine.

A cabine classe III deverá ser conectada a uma autoclave de duas portas e/ou um tanque de imersão química para esterilizar ou desinfetar os materiais que dela saírem e permitir que nela entrem os estoques. É típica a instalação de várias cabines classe II como um sistema interconectado. 


\begin{tabular}{|c|c|c|c|c|c|}
\hline Tipo Ve & $\begin{array}{l}\text { locidade } \\
\text { frontal }\end{array}$ & $\begin{array}{l}\text { Padrão de } \\
\text { fluxo de ar }\end{array}$ & $\begin{array}{l}\text { Radionuclideos/ } \\
\text { substâncias } \\
\text { químicas }\end{array}$ & $\begin{array}{l}\text { Níveis de } \\
\text { biossegu- } \\
\text { rança }\end{array}$ & $\begin{array}{c}\text { Proteção } \\
\text { do } \\
\text { produto }\end{array}$ \\
\hline $\begin{array}{l}\text { Classe } \\
\text { I com } \\
\text { frente } \\
\text { aberta }\end{array}$ & 75 & $\begin{array}{l}\text { Frontal, atrás e } \\
\text { acima por meio } \\
\text { de filtro } \\
\text { HEPA }\end{array}$ & Não & 2,3 & Não \\
\hline $\begin{array}{l}\text { Classe } \\
\text { II } \\
\text { Tipo A }\end{array}$ & 75 & $\begin{array}{l}70 \% \text { de ar recircu- } \\
\text { lado por meio de filtro } \\
\text { HEPA; exaustão de ar } \\
\text { por filtro HEPA }\end{array}$ & r & 2,3 & Sim \\
\hline $\begin{array}{l}\text { Classe } \\
\text { II } \\
\text { Tipo B1 }\end{array}$ & 100 & $\begin{array}{l}30 \% \text { de ar recircula- } \\
\text { por meio de filtro } \\
\text { HEPA; exaustão de ar } \\
\text { por filtro HEPA e } \\
\text { dutos }\end{array}$ & Sim & 2,3 & Sim \\
\hline $\begin{array}{l}\text { Classe } \\
\text { II } \\
\text { Tipo B2 }\end{array}$ & 100 & $\begin{array}{c}\text { Nenhuma recircula- } \\
\text { ção de ar; total } \\
\text { exaustão por meio } \\
\text { de filtro HEPA e } \\
\text { dutos }\end{array}$ & Sim & 2,3 & Sim \\
\hline $\begin{array}{l}\text { Classe } \\
\text { II } \\
\text { Tipo B3 }\end{array}$ & 100 & $\begin{array}{l}\text { Idêntica da classe II A, } \\
\text { mas com sistema de } \\
\text { ventilação total sob } \\
\text { pressão negativa para } \\
\text { sala e exaustão por } \\
\text { meio de dutos }\end{array}$ & , & 2,3 & Sim \\
\hline $\begin{array}{c}\text { Classe } \\
\text { III }\end{array}$ & NA & $\begin{array}{l}\text { Entrada e saída de } \\
\text { ar por meio de } \\
\text { filtro HEPA }\end{array}$ & Sim & 3,4 & Sim \\
\hline
\end{tabular}

QuADRo 4.1 - Comparação entre os tipos de cabines de segurança biológica 


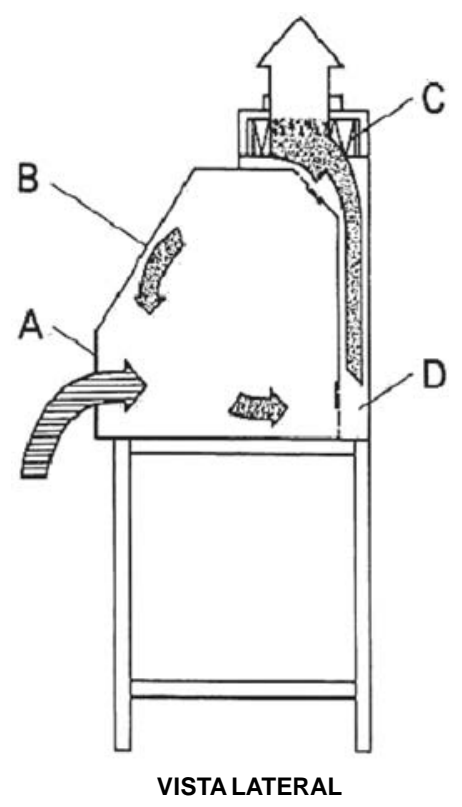

Fıgura 4.1 - Cabine de Segurança Biológica classe I: (A) abertura frontal; (B) vidraça corrediça; (C) filtro HEPA para exaustão; (D) espaço de exaustão Fonte: Brasil (2001), com modificações.

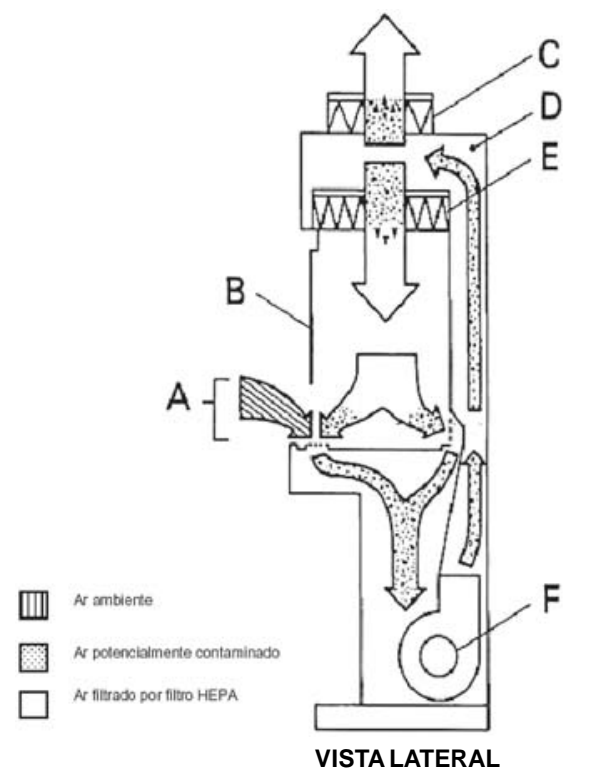

FIGURA 4.2a - Cabine de Segurança Biológica classe II tipo A: (A) abertura frontal; (B) vidraça corrediça; (C) filtro HEPA para exaustão; (D) espaço posterior; (E) filtro HEPA para o suprimento de ar; $(F)$ ventilador.

Fonte: Brasil (2001), com modificações. 


\section{Conexão necessária de sistema de exaustores do edifício}

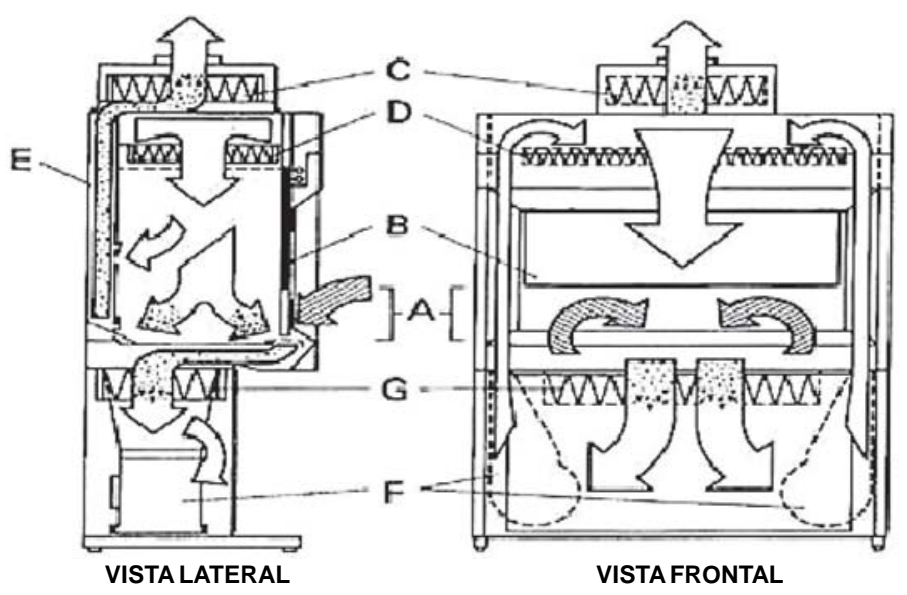

Figura 4.2b - Cabine de Segurança Biológica classe II tipo B1 (desenho clássico): (A) abertura frontal; (B) vidraça corrediça; (C) filtro HEPA para exaustão; (D) filtro HEPA para o suprimento de ar; (E) espaço de exaustão com pressão negativa; $(F)$ ventilador; (G) filtro HEPA adicional para o suprimento de ar

Obs.: exaustor da cabine necessita ser conectado ao sistema de exaustores do edifício. Fonte: Brasil (2001), com modificações.

\section{Conexão necessária de sistema de exaustores do edifício}

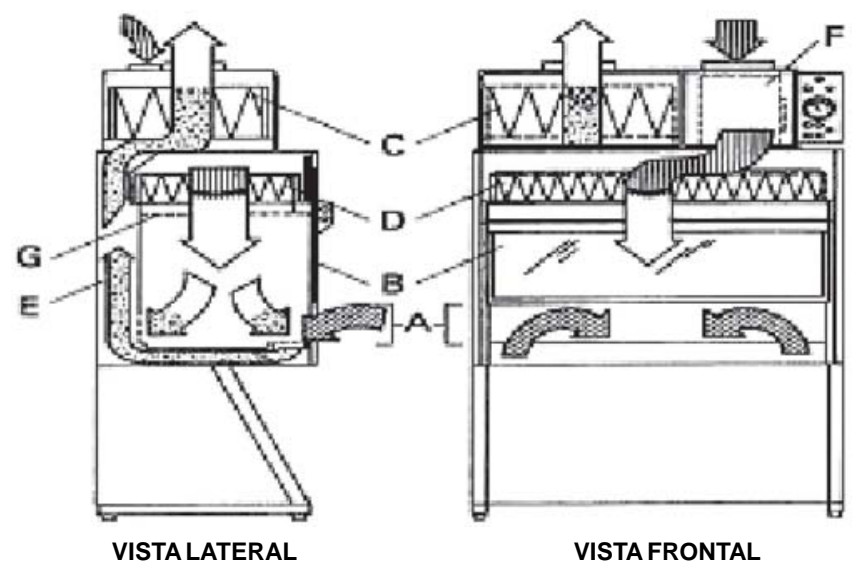

Figura 4.2c - Cabine de Segurança Biológica classe II tipo B2: (A) abertura frontal; (B) vidraça corrediça; (C) filtro HEPA para exaustão; (D) filtro HEPA para suprimento de ar; (E) espaço de exaustão com pressão negativa; $(F)$ tela do filtro.

Obs.: o filtro de carbono do sistema de exaustores do edifício não está mostrado nesta figura; o ar de exaustão na cabine deverá ser conectado ao sistema de exaustores do edifício.

Fonte: Brasil (2001), com modificações. 


\section{Conexão necessária de sistema de exaustores do edifício}

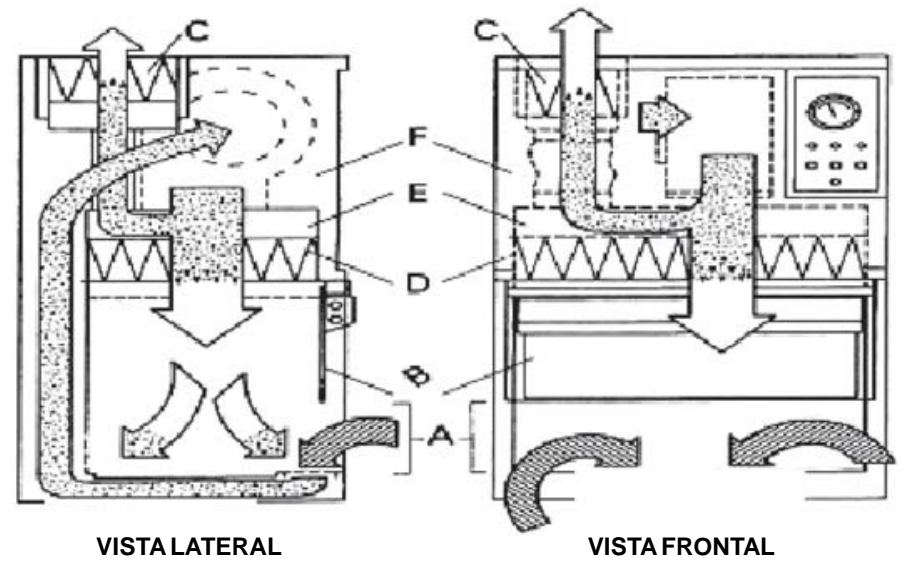

Figura 4.2d - Cabine de Segurança Biológica classe II tipo B3 (modelo de mesa): (A) abertura frontal; (B) vidraça corrediça; (C) filtro HEPA de exaustão; (D) filtro HEPA para suprimento de ar; (E) espaço de pressão positiva; (F) espaço de pressão negativa. Obs.: os exaustores da cabine deverão ser conectados aos sistemas dos exaustores do edifício.

Fonte: Brasil (2001), com modificações.

\section{Conexão necessária de sistema de exaustores do edifício}

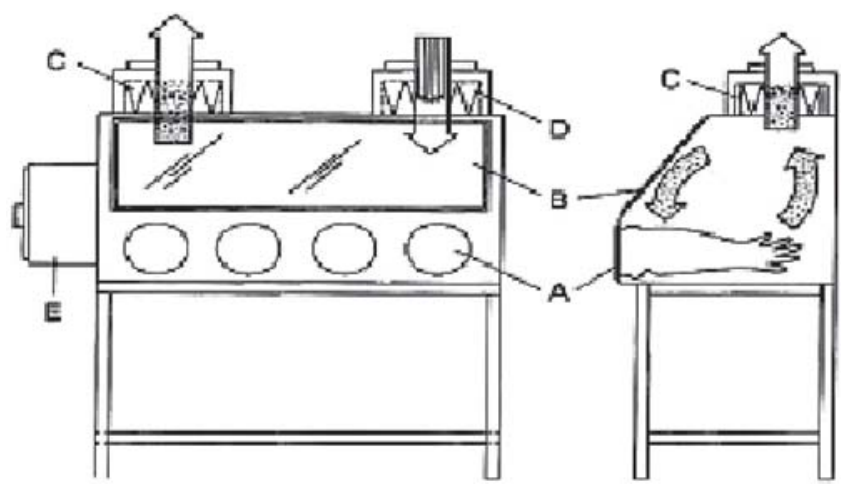

FIgURA 4.3 - Cabine de Segurança Biológica classe III: (A) compartimento para fixação de luvas longas de borracha à cabine; (B) vidraça corrediça; (C) filtro HEPA para exaustão; (D) filtro HEPA para o suprimento de ar; (E) autoclave dupla saída na extremidade ou caixa de passagem da cabine.

Obs.: um tanque de imersão química pode ser instalado e deverá ser colocado abaixo da superfície de trabalho da CSB com o acesso por cima. O sistema de exaustores da cabine necessita ser conectado a um sistema de exaustores independente.

Fonte: Brasil (2001), com modificações. 


\section{ANIMAIS E PRINCIPAIS DOENÇAS TRANSMITIDAS}

Os quatro níveis de biossegurança acima discutidos também são descritos para atividades que envolvam doenças infecciosas em animais de experimentação. Essas quatro combinações de práticas, equipamentos de segurança e de instalações são denominadas de níveis de biossegurança animal 1, 2, 3 e 4 e proporcionam níveis crescentes de proteção aos profissionais e ao meio ambiente.

Existem procedimentos básicos de segurança, tanto em laboratório como no campo, quando se lida com vertebrados. Isso porque esses animais podem representar riscos para quem os manuseia: embora não infectados experimentalmente, podem portar agentes patogênicos - inclusive zoonóticos. Portanto, pesquisador e estagiário devem seguir algumas regras básicas não só para diminuir os riscos, mas também para minimizar o estresse do animal.

Os biotérios devem manter boa qualidade de vida dos animais para estudo e garantir a limpeza do ambiente de trabalho do pesquisador, o que contribui para evitar doenças. Para isso, os biotérios devem ter as seguintes condições para manutenção:

- boa alimentação para as cobaias;

- boa iluminação;

- ventilação adequada, com exaustores;

- limpeza das bancadas e pisos com germicida para eliminar infecção; piso não escorregadio;

- lavagem de caixas onde ficam ratos, camundongos ou coelhos periodicamente, trocando as serragens;

- lotação adequada dos animais nas caixas segundo a capacidade: caixas pequenas suportam até 10 camundongos, e as caixas grandes, até 20 animais.

Os quadros 4.2 a 4.6 apresentam uma relação de mamíferos e aves potenciais portadores de doenças que afetam o homem e as respectivas zoonoses que podem transmitir, incluindo nome da doença, agentes e forma de disseminação. 


\begin{tabular}{|c|c|}
\hline Animal hospedeiro & Doença \\
\hline Cães & $\begin{array}{l}\text { Brucelose, leptospirose, pneumonia, tuberculose, } \\
\text { ricketsiose, dermatomicoses, histoplasmose e amebíase }\end{array}$ \\
\hline Gatos & Dermatomicoses e toxoplasmose \\
\hline Primatas não-humanos & $\begin{array}{l}\text { Pneumonia, shiguelose, tuberculose, encefalites virais, } \\
\text { hepatite, protozoonoses sangüíneas e amebíase }\end{array}$ \\
\hline Suínos & Brucelose, colibacilose, tuberculose e dermatomicoses \\
\hline Caprinos & Brucelose \\
\hline Bovinos & Brucelose, coccidiose e tuberculose \\
\hline Lagomorfos & Ricketioses, tularemia e pneumonia \\
\hline Ovinos & Brucelose e colibacilose \\
\hline Aves & $\begin{array}{l}\text { Colibacilose, pasteurelose, pseudotuberculose, tubercu- } \\
\text { loses, dermatomicoses, clamidiose e psitacose }\end{array}$ \\
\hline Roedores & $\begin{array}{l}\text { Leptospirose, pseudotuberculose, ricketioses, febres } \\
\text { hemorrágicas, coriomeningite linfocitária, dermatomico- } \\
\text { ses, protozoonoses sangüíneas e hantaviroses }\end{array}$ \\
\hline
\end{tabular}

QUADRo 4.2 - Animais e respectivas doenças potenciais Fonte: Adaptado de Báo (2000).

\begin{tabular}{|c|c|c|}
\hline Nome & Agente & Disseminação \\
\hline Febre hemorrágica & $\begin{array}{l}\text { Vírus da febre } \\
\text { hemorrágica }\end{array}$ & $\begin{array}{l}\text { Contato, alimento contami- } \\
\text { nado com excretas }\end{array}$ \\
\hline Coriomeningite linfocitária & $\begin{array}{l}\text { Vírus da coriomeningite } \\
\text { linfocitária (LCMV) }\end{array}$ & $\begin{array}{l}\text { Contato, inalação, transmis- } \\
\text { são congênita, cultura de } \\
\text { células }\end{array}$ \\
\hline Encefalite herpética $B$ & Herpes simiae & Contato, mordedura \\
\hline Hepatite A & Vírus da hepatite $A$ & Contato \\
\hline Raiva & Vírus rábico & $\begin{array}{l}\text { Contato com saliva contami } \\
\text { nada, mordedura }\end{array}$ \\
\hline
\end{tabular}

QuAdro 4.3 - Nome, agente e disseminação das doenças virais Fonte: Adaptado de Báo (2000).

\begin{tabular}{|lll|}
\hline Nome & Agente & Disseminação \\
\hline Ricketsia akari & Camundongos & Picada \\
Ricketsia ricketsia & Roedores, cães, lagomorfos, ovinos & $\begin{array}{l}\text { Picada } \\
\text { Ricketsia mosseri }\end{array}$ \\
Ratos, camundongos & Picada \\
\hline
\end{tabular}

QuAdRo 4.4 - Agentes, hospedeiros e disseminação de ricketsioses Fonte: Adaptado de Báo (2000). 


\begin{tabular}{|lll|}
\hline Nome & Agente & Disseminação \\
\hline Brucelose & Brucella suis, B. canis, & Contato, ingestão \\
& B. abortus, B. melitensis & \\
Clamidiose e psitacose & Chlamydia sp & Inalação \\
Colibacilose & Escherichia coli & Ingestão \\
Leptospirose & Leptospira sp & Contato com urina, água \\
Peste & Pasteurella pestis & Contato, inalação \\
Pasteurelose & Pasteurella multocida & Contato, ingestão \\
Pneumonia & Bordetella bronchiseptica & Inalação, contato \\
Pseudotuberculose & Yersinia pseudotuberculosis & Contato, ingestão \\
Febre por mordida & Spirilium minus, & Ingestão, mordida de \\
\multicolumn{1}{c}{ de rato } & S. moniliformes & roedores \\
Salmonelose & Salmonela sp & Ingestão, inalação, contato \\
Shiguelose & Shiguela sp & Contato, contaminação por \\
& & fezes \\
Tétano & Clostridium tetani & Contaminação de feridas \\
Tuberculose & Micobacterium sp & Inalação, ingestão, contato \\
Tularemia & Francisella tularensis & Contato, ingestão \\
\hline
\end{tabular}

QuAdro 4.5 - Agentes e disseminação de doenças bacterianas Fonte: Adaptado de Báo (2000).

\begin{tabular}{|c|c|c|}
\hline Nome & Agente & Disseminação \\
\hline Dermatomicose & $\begin{array}{l}\text { Trychophytum sp, Microspo- } \\
\text { rum sp, Dernatophytum sp }\end{array}$ & Contato direto \\
\hline Histoplasmose & Histoplasma sp & Inalação de esporos \\
\hline Coccidiose & Coccidioides immitis & Inalação de esporos \\
\hline Toxoplasmose & Toxoplasma gondii & $\begin{array}{l}\text { Ingestão de oocistos, ingestão } \\
\text { de carnes contaminadas, } \\
\text { transmissão congênita }\end{array}$ \\
\hline $\begin{array}{l}\text { Protozoonoses } \\
\text { sangüíneas }\end{array}$ & $\begin{array}{l}\text { Trypanosoma sp, } \\
\text { Plasmodium } \mathrm{sp} \\
\text { Leishmania sp }\end{array}$ & $\begin{array}{l}\text { Transmissão direta, contami- } \\
\text { nação pela saliva contamina } \\
\text { e insetos vetores }\end{array}$ \\
\hline Amebíase & Entamoeba histolitica & Alimento contaminado \\
\hline Paracoccidioidomicose & $\begin{array}{l}\text { Paracoccidioides } \\
\text { brasiliensis }\end{array}$ & $\begin{array}{l}\text { Inalação de esporos, } \\
\text { contaminação de ferimentos }\end{array}$ \\
\hline
\end{tabular}

Quadro 4.6 - Nome, agente e disseminação de doenças potenciais provocadas por fungos e protozoários

Fonte: Adaptado de Báo (2000). 


\section{POSTURAS E PROCEDIMENTOS}

Algumas posturas e certos procedimentos são necessários em laboratórios para que as medidas de biossegurança sejam efetivas e haja prevenção quanto a acidentes e contaminação.

- Lavar as mãos antes e logo após o manuseio de materiais químicos e animais, sejam estes venenosos ou não;

- Manter sempre o cabelo preso;

- Nunca pipetar com a boca; use pipetadores automáticos, manuais ou pêras de borracha;

- Não comer, não beber nem preparar alimentos dentro do laboratório;

- Não fumar no laboratório;

- Não guardar alimentos em geladeiras e congeladores utilizados para armazenamento de material biológico ou químico, e viceversa;

- Não trabalhar com material patogênico se houver ferida na mão, no pulso ou em qualquer outra parte do corpo que possa entrar em contato com a substância nociva;

- Usar equipamentos de proteção individual (EPI) adequados;

- Não manipular objetos de uso comum como telefones, maçanetas, jornais ou revistas enquanto estiver usando luvas, para não contaminá-los;

- Tomar vacina antitetânica para evitar contágio em caso de ferimento; caso o trabalho envolva manipulação de animais e sangue humano, aconselha-se também a vacina anti-rábica e contra hepatite $B$, respectivamente;

- Usar luvas apropriadas quando for necessário alimentar ou dar água aos animais (para cada animal existe procedimentos e equipamentos adequados). Nunca se deve pegar ou mexer com as mãos nuas em qualquer objeto que esteja dentro da gaiola;

- Evitar transportar materiais químicos ou biológicos de um lugar para outro no laboratório, pois esse procedimento aumenta o risco de acidentes;

- Evitar trabalhar sozinho no laboratório; caso isso se faça necessário, deixar avisado com algum outro integrante do laboratório;

- Procurar saber onde ficam os equipamentos de proteção coletiva (EPC) e como utilizá-los;

- Trabalhar sempre de calça comprida de tecido resistente, calçados fechados não derrapantes (de preferência sapatos de couro), roupas de algodão e usar os equipamentos de proteção individual;

- Quando iniciar um novo procedimento, imaginar os possíveis casos de acidente, como evitá-los e o que fazer caso ocorram. Isso torna o socorro muito mais rápido e eficiente, a ponto de salvar vidas. 
Equipamentos de PROTEÇÃo INDIVIDUAL (EPI)

- Avental ou jaleco de algodão, de mangas compridas e punho retrátil

- Luvas de proteção

- Máscara com filtro apropriado; pipetador automático

- Protetor facial

- Pêra de borracha

- Óculos de proteção

Equipamentos de PRoteção Coletiva (EPC)

- Extintores de incêndio

- Chuveiros de segurança, lava-olhos

- Pia para lavagem das mãos

- Capelas de fluxo laminar e de exaustão

- Exaustores

- Caixas com luvas

- Recipientes para rejeitos

- Caixa de primeiros socorros

- recipientes especiais para transporte de material contaminado e/ou animais.

Além disso, verificar sempre as condições de funcionamento dos equipamentos de proteção coletiva.

MANUTENÇão de UMA CAIXA DE PRIMEIROS SOCORROS

Recomenda-se manter uma caixa de primeiros socorros com seguintes produtos:

- conta-gotas;

- atadura e esparadrapo;

- mertiolate; cotonetes;

- álcool; soro fisiológico;

- curativos adesivos;

- picrato de butezin;

- tesoura;

- lâmina de barbear;

- bolsa de água;

- pinça;

- lenço;

- alfinetes;

- um garrote (meio metro de borracha flexível);

- analgésico;

- vaselina esterilizada;

- termômetro. 
Além desses produtos, é importante que o laboratório tenha soluções neutralizantes para queimaduras e lesões provocadas por ácidos e bases, além de antídotos para contaminações por outros agentes tóxicos (como cianetos). Essas informações podem ser obtidas em cartazes usualmente encontrados junto ã maioria dos laboratórios.

Sinalização

Identifique e sinalize riscos biológicos, físicos e químicos presentes em seu laboratório. Atente-se, também, para os símbolos que aparecem nos rótulos de produtos químicos.

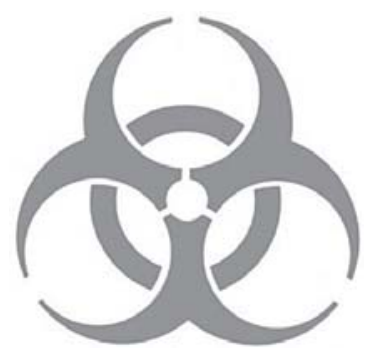

Sinalização para risco biológico

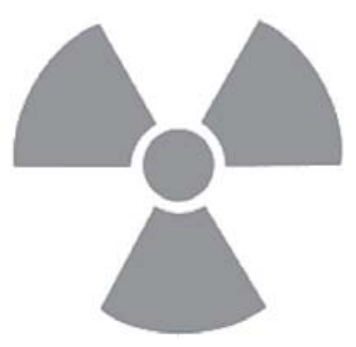

Sinalização para risco com radiação ionizante

\section{CONCLUSÃO}

No presente capítulo, foram descritos os pontos julgados mais relevantes no que se refere aos riscos no trabalho com agentes biológicos cujas características peculiares - quer sejam estes microorganismos (vírus, bactérias, fungos, protozoários ou ácaros), animais ou plantas - exigem do profissional e dos estudantes que os manipulam um conhecimento aprofundado de suas características, assim como das técnicas utilizadas em procedimentos de coleta, armazenamento, transporte e manipulação em laboratório, para que sejam instituídas normas eficazes de biossegurança. Estas devem ser elaboradas à luz das peculiaridades de cada laboratório, com base em legislações e normas nacionais e internacionais. 


\section{ATENÇÃO}

Antes de iniciar qualquer atividade (desde um estágio de curta duração até um envolvimento maior em trabalhos experimentais de média ou longa duração) em laboratório que manipule agentes químicos, físicos ou biológicos, solicite informações ao responsável pelo laboratório sobre os procedimentos adotados relativos a biossegurança, bem como uma cópia do manual de biossegurança do laboratório. Caso não seja instruído(a) o suficiente nessas questões, o mais prudente é que você desista de iniciar suas atividades neste laboratório.

\section{REFERÊNCIAS}

BÁO, S. N. Cartilha de segurança para o campo e laboratório. Brasília, DF: Universidade de Brasília, 2000. 71p.

BRASIL. Ministério da Saúde. Fundação Nacional de Saúde. Biossegurança em laboratórios biomédicos e de microbiologia. Editado por Jonathan Y. Richmond, Robert W. Mckinney; organizado por Ana Rosa dos Santos, Maria Adelaide Millington, Mário Cesar Althoff. Brasília, DF, 2001. 290p.

UNITED STATES OF DEPARTMENT OF HEALTH AND HUMAN SERVICES. National Institute of Health, Center for Disease Control and Prevention. Biosafety in microbiological and biomedical laboratories. 4th. ed. Washington, 1999. (Publication (CDC) 938395). Disponível em: <http://www.cdc.gov/od/ohs/biosfty/bmbl4/ bmbl4toc.htm>. Acesso em: 11 maio 2005.

OKLAHOMA STATE UNIVERSITY. Laboratory safety manual. Stillwater, 1999. 267 p. Disponível em: <http://www.pp.okstate.edu/ ehs/HAZMAT/Labman.htm>. Acesso em: 11 maio 2005.

TEIXEIRA, P.; VALLE, S. Biossegurança: uma abordagem multidisciplinar. Rio de Janeiro: FIOCRUZ, 1996. 362p. 


\section{PARTE II}

\section{TIPOS DE ESTUDOS}

E METODOLOGIA ESTATÍSTICA 
5.

\title{
CONCEITOS BÁSICOS DE EPIDEMIOLOGIA
}

\author{
José Roberto Mineo \\ Deise Aparecida de Oliveira Silva
}

\section{INTRODUÇÃO}

A epidemiologia está incluída na categoria dos estudos populacionais ao lado da genética e das ciências sociais, dentre outras disciplinas. Trata-se de uma área científica que lida com o comportamento coletivo da saúde e da doença.

Em clínica, observa-se que o foco de interesse é o indivíduo — seja um doente ou alguém saudável - que pede cuidados. $O$ clínico, em sua atividade, lida com dados de anamnese, exame físico e laboratorial para chegar a um diagnóstico individual. Em epidemiologia, os doentes ou os indivíduos sadios também são levados em consideração, mas em conjunto, sendo agrupados para se diagnosticar o que ocorre no grupo, unidade de interesse. Caso seja necessário recorrer a técnicas de estatística para expressar resultados, estes poderão ser expressos na forma de coeficientes para se obterem informações sobre diversos parâmetros, como por exemplo, mortalidade ou morbidade, que sejam de interesse para um diagnóstico coletivo.

\section{CONCEITOS E MÉTODOS}

Os conceitos e métodos utilizados em epidemiologia visam esclarecer situações de natureza bastante diversa; por exemplo, a determinação das características de alguma doença, a evolução, os fatores determinantes e associados, assim como a avaliação de tecnologias utilizadas em prevenção, diagnóstico e tratamento. Informações desse tipo interessam muito ao clínico, pois são inerentes ao processo de diagnóstico e manuseio de pacientes. No entanto, a informação que chega a ele, ou é produzida por ele, deve ser gerada adequadamente: sem vieses (tendenciosidades) ou deficiências que possam reduzir a validade dos resultados. 
Já existe um movimento para não limitar a epidemiologia ao âmbito da saúde pública - campo de aplicação mais tradicional - e estendê-la às áreas clínicas. A justificativa para isso se fundamenta no fato de a perspectiva populacional permitir o controle de muitas inconsistências provenientes de generalizações feitas com base em relatos isolados de casos - pois estes tendem a realçar situações que, apesar de interesse clínico, podem ser atípicas e, portanto, de pouca freqüência.

É significativa a preocupação, em epidemiologia, com a definição clara do grupo de indivíduos submetido ao estudo, de modo que estejam representadas as diversas categorias de pacientes e pessoas sujeitas ao risco de adoecer. Orientação para a realização de tais estudos é encontrada em textos de epidemiologia e de disciplinas com as quais ela tem grande inter-relação, como estatística e metodologia científica.

Para alguns interessados nesses tipos de estudos, o foco principal pode ser menos o de realizar investigações do que entendê-las adequadamente e aplicá-las no campo de interesse. Esse melhor entendimento pode resultar de uma compreensão mais precisa dos métodos utilizados em epidemiologia, o que aumenta o interesse pela leitura de novos artigos científicos e aplicação dos resultados destes na prática diária.

\section{A EPIDEMIOLOGIA E O PROCESSO SAÚDE-DOENÇA}

Pode-se conceituar atualmente epidemiologia como a ciência que estuda o processo saúde-doença na comunidade: analisa a distribuição e os fatores determinantes das doenças e dos agravos à saúde coletiva e sugere medidas específicas de prevenção, controle ou erradicação. Nesse contexto, deve-se entender tal processo como dinâmico: vai do estado de completo bem-estar físico, psíquico e social ao que caracteriza a presença de enfermidade, em que a ausência gradual ou completa de um corresponde ao preenchimento do espaço do outro e vice-versa.

Princípio básico e fundamental em epidemiologia As doenças não se distribuem ao acaso ou de forma aleatória em uma população; existem fatores de risco que determinam a distribuição. 


\section{MORTALIDADE E MORBIDADE}

Mortalidade e morbidade são variáveis características de comunidades de seres vivos e se referem ao conjunto dos indivíduos que morreram (mortalidade) ou adquiriram doenças (morbidade) num determinado intervalo de tempo.

Medidas de mortalidade são aquelas relativas à morte de indivíduos da população. Entre elas, destacam-se:

- Taxa de Mortalidade Total;

- Taxa de Mortalidade Específica;

- Taxa de Mortalidade Infantil;

- Razão de Mortalidade Proporcional.

A Taxa de Mortalidade Total (TMT) é definida com base na seguinte fórmula:

$$
\mathrm{TMT}=\frac{\text { Número total de mortes em um ano }}{\text { População total em } 1^{\circ} \text { de janeiro }} \times 1.000
$$

Exemplo: Uberlândia (MG), Brasil, 2000. População: 501.214. Mortes: 2.354

Taxa de Mortalidade Total $=(2.354 / 501.214) \times 1000$ $=4,7$ mortes $/ 1.000$ hab./ano.

A Taxa de Mortalidade Específica (TME) é definida como o número de mortes em determinado grupo relativamente à população total. Pode ser específica por idade, raça, sexo, causa de morte, ou combinando-se duas ou mais dessas características.

$$
\mathrm{TME}=\frac{\text { Número total de mortes no grupo }}{\text { População total do grupo }} \times 100.000
$$

Exemplo: Uberlândia, 2000. Mortes por neoplasias malignas: 308. População: 501.214.

Taxa de Mortalidade Específica por causa $=(308 / 501.214)$ $\mathrm{x} 100.000$

$=61,4$ mortes por neoplasias malignos/100.000 hab./ano.

A Taxa de Mortalidade Infantil (TMI) é definida conforme a seguinte fórmula:

$$
\mathrm{TMI}=\frac{\text { Número de mortes de crianças menores de } 1 \text { ano }}{\text { Número de nascidos vivos no mesmo período }} \times 1.000
$$


Exemplo: Uberlândia, 2000. Nascidos vivos: 8.517.

Mortes de menores de 1 ano de idade: 143.

Taxa de Mortalidade Infantil $=(143 / 8.517) \times 1.000$

$=16,8$ mortes infantis/1.000 hab./ano.

A Razão de Mortalidade Proporcional (RMPro) é definida com base na seguinte fórmula:

RMPro $=\frac{\text { Número de mortes devidas a uma determinada causa no ano }}{\text { Número total de mortes no ano }} \times 100$

Exemplo: Uberlândia, 2000. Total de mortes: 2.354 .

Total de mortes devidas a neoplasias malignas: 308 .

Razão de Mortalidade Proporcional $=(308 / 2.354) \times 100$

$=13,1 \%$ de mortes por neoplasias malignas/ano.

\section{OUTRAS TAXAS DE MORTALIDADE}

Existem taxas relativas à gravidez, ao nascimento e à infância: - Razão de Mortalidade Materna: número de mortes devidas a causas puerperais em relação ao número de nascimentos vivos em um ano multiplicado por 100.000 ;

- Proporção de Mortalidade Neonatal: número de mortes de neonatos em um ano em relação ao número de nascidos vivos multiplicado por 1.000;

- Razão de Mortalidade Fetal: número de mortes fetais em relação ao número de nascidos vivos no ano multiplicado por 1.000;

- Proporção de Mortalidade Perinatal: número de mortes fetais e neonatais em relação ao número de nascidos vivos e de mortes fetais multiplicado por 1.000 .

\section{AJUSTES DE TAXAS DE MORTALIDADE}

São processos que permitem o estabelecimento de comparações entre as taxas de mortalidade; podem ser obtidos pelos seguintes métodos:

- método direto: aplicação de uma distribuição populacional padrão às taxas de mortalidade de dois grupos de comparação;

- método indireto: utilizado quando não se conhece a taxa de mortalidade específica das populações comparadas, mas se conhece essa taxa de uma população padrão utilizada como referência.

O cálculo da Razão de Mortalidade Padrão (RMP) é feito segundo a seguinte fórmula: 


$$
\mathrm{RMP}=\frac{\text { Mortes observadas }}{\text { Mortes esperadas }}
$$

Medidas de morbidade são todas as medidas utilizadas para se mensurar a freqüência de doenças na população. Entre elas, destacam-se:

- Proporção de Fatalidade ou Letalidade;

- Taxa de Incidência;

- Taxa de Prevalência.

Proporção de Fatalidade ou Letalidade (PL) é definida conforme a seguinte fórmula:

$$
\mathrm{PL}=\frac{\text { Número de mortes devido a uma doença em um período }}{\text { Número de casos dessa doença na população }} \times 100
$$

Exemplo: Brasil, 2003. Número de casos de AIDS em homens: 3.693. Número de homens mortos com AIDS: 912.

Proporção de Letalidade $=(912 / 3693) \times 100$

$=24,7 \%$ de mortalidade devido à AIDS.

Observa-se que em algumas circunstâncias o emprego de tais variáveis em epidemiologia pode não ser prático para efeito de comparação de freqüências numéricas, como freqüências absolutas, associadas àquelas variáveis ocorridas em comunidades diferentes em uma mesma época ou para uma mesma comunidade em períodos diferentes. Assim, os termos mortalidade e morbidade podem ser utilizados freqüentemente segundo formas qualificativas para especificar as causas da doença ou da morte, grupos etários, sexo, local e outros parâmetros.

A análise dos índices de mortalidade tem como característica fundamental permitir a avaliação do nível de saúde e direcionar medidas de caráter abrangentes que visem melhorar o estado de saúde de uma comunidade. Para garantir a correção da tomada de decisões que se referem aos eventos específicos de saúde e doença ou apoiar a implementação de ações necessárias a fim de permitir o controle dos acontecimentos daí resultantes, consultam-se os coeficientes de morbidade discriminados em coeficientes de prevalência e coeficientes de incidência.

\section{PREVALÊNCIA E INCIDÊNCIA}

Como conceito geral, o termo prevalência denota uma propriedade dos acontecimentos fazendo com que estes se destaquem 
da circunstância. Como termo utilizado na ciência epidemiológica, no entanto, prevalência denota a casuística de morbidade que se destaca por seus valores maiores que zero sobre os eventos de saúde ou de doença. Desta maneira, prevalência é um termo descritivo da força com que subsistem as doenças nas comunidades (Figura 5.1).

Prevalência

Número de casos existentes, independentes de serem novos ou antigos, num período determinado de tempo.

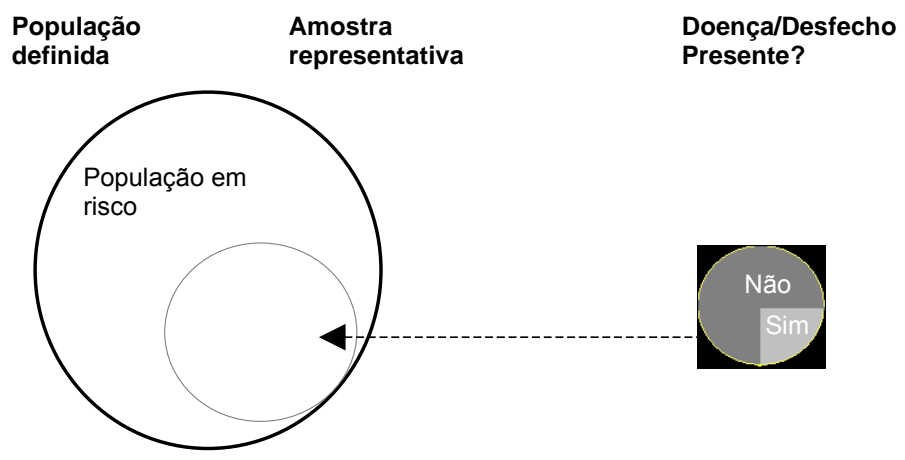

Figura 5.1 - Delineamento de um estudo de prevalência

Para que se possa operacionalizar este parâmetro, utiliza-se o coeficiente, ou a taxa de prevalência, que pode ser expresso como a relação entre o número de casos conhecidos de uma dada doença e a população, multiplicando-se o resultado pela base referencial da população estudada na potência de 10, como 1.000, 10.000 ou 100.000 (Quadro 5.1).

Taxa de Prevalência (TP) é definida segundo a seguinte fórmula:

TP $=\frac{\text { Número de casos existentes de uma doença em um período }}{\text { População total no período }} \times 100.000$

Exemplo: Brasil, 2000.

População: 92.489 .703 habitantes na faixa etária de 15 a 49 anos.

Número de indivíduos infectados pelo HIV na faixa etária de 15 a 49 anos: 597.443.

Taxa de Prevalência $=(597.443 / 92.489 .703) \times 100.000$

TP $=646$ casos de indivíduos infectados pelo HIV/100.000 habitantes na faixa etária de 15 a 49 anos. 


\section{Caso}

Definindo o numerador:

Termo usado para indicar o indivíduo que apresenta a doença ou o desfecho de interesse.

\section{População}

Para os epidemiologistas:

Definindo o denominador:

$\rightarrow$ consiste em todos os indivíduos residentes em uma área geográfica.

Para estudos de causa e efeito:

$\rightarrow$ consiste em populações que sofrem de determinadas doenças ou apresentam certas características e que se encontram em um cenário clínico similar àquele em que a informação será usada.

Quadro 5.1 - Definições de caso e população

Os conceitos de prevalência e incidência têm como um eixo comum a idéia central relacionada ao ato de acontecer. Dessa maneira, compreende-se "prevalecer" como a seqüência de ações de "acontecer" e "permanecer acontecendo" num determinado espaço de tempo, enquanto "incidir" relaciona-se simplesmente ao ato de acontecer sem necessidade de acréscimos complementares. Assim, incidência em epidemiologia está relacionada com a noção de intensidade com que acontece a morbidade de determinada doença em dada população, enquanto prevalência relaciona-se à força com que subsiste determinada doença numa dada comunidade. As características mais relevantes de incidência e prevalência são mostradas no Quadro 5.2.

\begin{tabular}{|c|c|c|}
\hline Característica & Incidência & Prevalência \\
\hline Numerador & $\begin{array}{l}\text { Casos novos que ocorrem durante } \\
\text { o período de acompanhamento } \\
\text { em um grupo inicialmente livre } \\
\text { da doença }\end{array}$ & $\begin{array}{l}\text { Todos os casos contados } \\
\text { em um único inquérito ou } \\
\text { exame de um grupo }\end{array}$ \\
\hline Denominador & $\begin{array}{l}\text { Todos os indivíduos susceptíveis } \\
\text { presentes no início do } \\
\text { acompanhamento }\end{array}$ & $\begin{array}{l}\text { Todos os indivíduos } \\
\text { examinados, incluindo } \\
\text { casos e não-casos }\end{array}$ \\
\hline Tempo & Duração do período & Ponto único \\
\hline Como é medida? & Estudo de coorte & Estudo de prevalência \\
\hline
\end{tabular}

QUADRo 5.2 - Comparação entre as características da incidência e prevalência

Operacionalmente, a incidência é mensurada pela freqüência absoluta de casos novos de determinada doença num dado 
intervalo de tempo. Tem-se, então, a definição de coeficiente, ou a taxa de incidência, que pode ser definido como a razão entre o número de casos novos de uma doença que ocorre numa comunidade, em um intervalo de tempo determinado, e a população exposta ao risco de adquirir tal doença no mesmo período, multiplicando-se o resultado por potência de 10 .

Taxa de Incidência (TI) é definida conforme a seguinte fórmula:

$$
\mathrm{TI}=\frac{\text { Número de casos novos de uma doença em um período }}{\text { População exposta ao risco de contrair a doença }} \times 100.000
$$

Exemplo: Brasil, 2003. Novos casos de AIDS: 5.762. População: 174.606.060.

Taxa de Incidência $=(5.762 / 174.606 .060) \times 100.000$ = 3,3 novos casos de AIDS/100.000 hab./ano.

\section{EPIDEMIA, PANDEMIA E ENDEMIA}

Epidemia é definida com base na ocorrência, em dada comunidade ou região, de elevação inesperada no número de casos de uma doença para aquele lugar e período. Quando uma epidemia é descrita, o período de tempo, a localização geográfica e as características do grupo no qual os casos ocorreram devem ser claramente especificadas. O número de casos indicativo da presença de uma epidemia varia conforme o agente, o tipo e o número de habitantes na população exposta, a experiência prévia ou ausência de exposição à doença e o tempo e o lugar de ocorrência.

A identificação de uma epidemia também depende da freqüência usual da doença naquela área para aquele grupo da população durante o mesmo período do ano. Um número muito pequeno de casos de uma doença não previamente reconhecida, associada ao tempo e lugar, pode ser suficiente para se constituir em epidemia. AFigura 5.2 representa um fluxograma do método de estudo em epidemia.

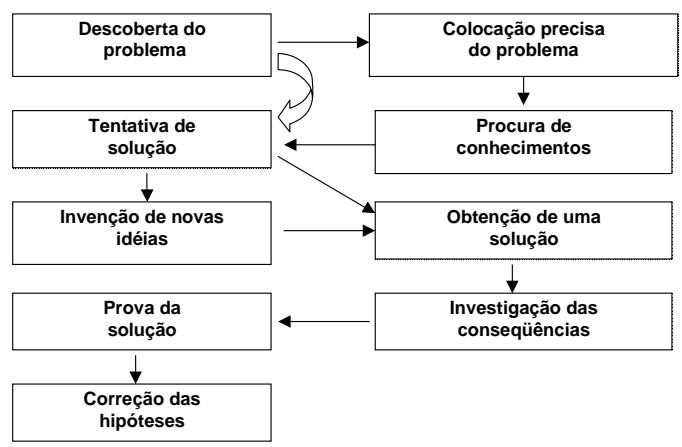

Figura 5.2 - Fluxograma de um método epidemiológico em epidemia 
Dentre os fatores responsáveis por uma epidemia, destacam-se aqueles relacionados ao agente, ao hospedeiro e ao ambiente. Considerando-se os fatores relativos ao agente, deve-se levar em conta a introdução de um novo agente ou da mudança no número de microorganismos vivos, bem como de mudanças na biologia do parasito ao interagir com o hospedeiro ou ambiente. Quanto aos fatores relacionados ao hospedeiro, há de se observarem as variações nos seus mecanismos de imunidade e sensibilidade às mudanças na sua densidade populacional e em movimentos migratórios, bem como às mudanças comportamentais ou de seus hábitos. Em relação aos fatores do ambiente, há que se investigarem as variações de temperatura, umidade e chuvas, e àqueles resultantes de mudanças nas condições socioeconômicas da população.

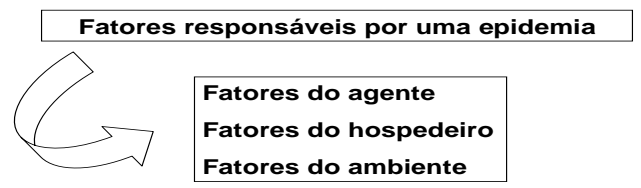

Quanto à velocidade a partir do estágio inicial, as epidemias podem ser classificadas em explosivas ou lentas. Denominam-se explosivas quando a manifestação da doença ocorre em pouco tempo e acomete quase a totalidade das pessoas atingidas. Assim, a incidência máxima deve ser alcançada logo após o início da egressão. Como exemplo desse tipo de epidemia pode-se citar a intoxicação alimentar em dado evento. As epidemias lentas se referem à baixa velocidade em que se verifica sua incidência máxima. Nesse caso, a ocorrência é gradualizada e progride durante um longo tempo. Exemplifica esse tipo de epidemia, dentre outras doenças, a hanseníase.

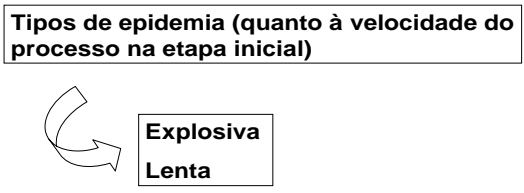

No que se refere à extensão do intervalo de tempo em que a fonte produziu seus efeitos, as epidemias podem ser estratificadas em epidemias de fonte pontual e epidemias de fonte persistente. No processo de fonte pontual, a exposição se dá durante curto intervalo de tempo, cessa e não se repete, ou torna essa hipótese minimizada. Um exemplo desse processo é a exposição a gases 
venenosos. No processo epidêmico de fonte persistente, a fonte tem existência dilatada e se prolonga por um período. $\mathrm{O}$ melhor exemplo é a contaminação da fonte hídrica por Salmonella.

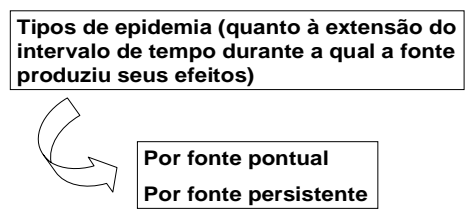

Quanto ao espaço geográfico onde se verifica sua abrangência, o processo epidêmico pode ser classificado em surto ou pandemia. Surto epidêmico refere-se à ocorrência epidêmica restrita a um espaço extremamente delimitado, como bairro, colégio, edifício, quartel, etc. Como exemplo, um surto de febre tifóide em determinado bairro. Por outro lado, pandemia refere-se a uma epidemia de grandes proporções que se espalha por vários países e por mais de um continente. Exemplo: AIDS no mundo.

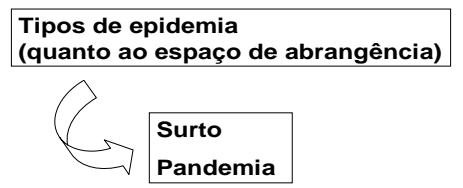

Ao se aplicar como modelo de estudo o método epidemiológico em epidemia apresentado na Figura 5.2 na pandemia da AIDS, pode-se construir para essa situação um fluxograma tal qual o que a Figura 5.3 representa.

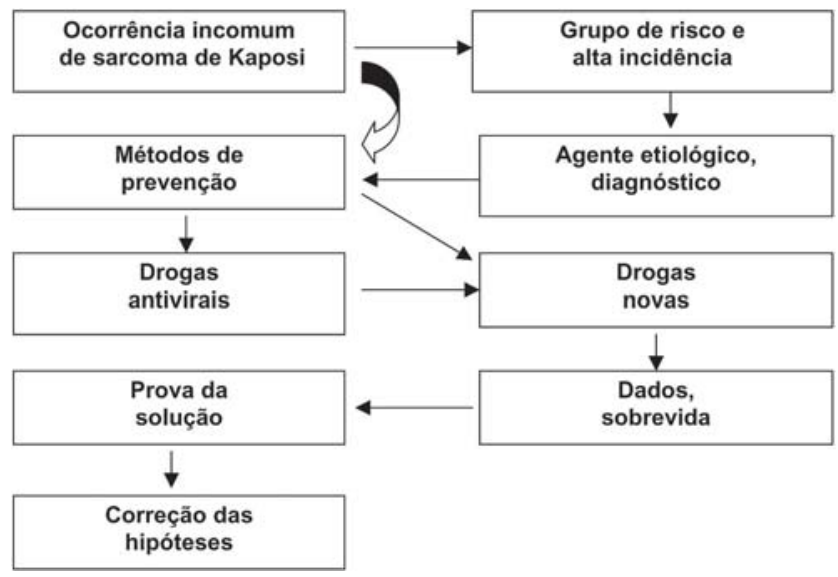

Figura 5.3 - Fluxograma de um método epidemiológico em AIDS 
Relativamente a uma endemia, o número de casos de uma doença é aquele normalmente presente ou que está dentro dos valores esperados para determinado lugar ou dada população.

\section{Endemia}

Presença constante de uma doença em uma população definida e em uma determinada área geográfica; pode também se referir à prevalência usual de uma dada doença em um grupo ou em uma área. Algumas doenças endêmicas podem eventualmente se manifestar em surtos epidêmicos.

Os índices relativos a determinada doença endêmica podem apresentar diferentes índices de prevalência e incidência, os quais podem ser comparados com outras áreas e populações onde ocorre a manutenção da infecção (Figura 5.4; Quadro 5.3)

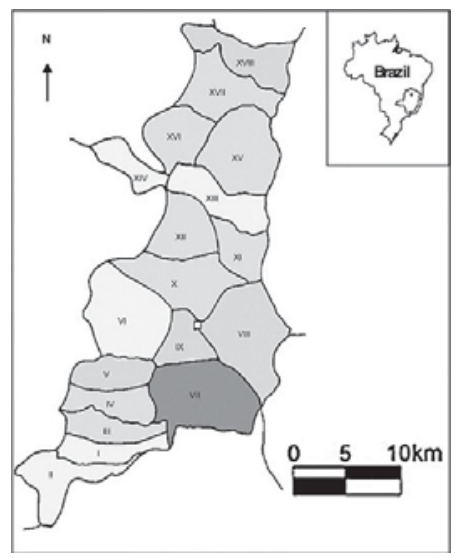

Figura 5.4 - Mapa físico das áreas endêmicas para leishmaniose canina visceral no município de Montes Claros, Minas Gerais, Brasil, em estudo conduzido com o objetivo de caracterizar diferentes aspectos dessa doença a fim de implementar estratégias para o controle epidemiológico. Áreas mais claras: menor endemicidade; áreas mais escuras: maior endemicidade. (escala: 1:200.000).

Fonte: França-Silva et al. (2003).

\section{Manutenção da infecção}

A manutenção da infecção na população está relacionada em primeiro lugar com a existência de reservatórios, portadores e hospedeiros susceptíveis.

Do ponto de vista epidemiológico, maior sucesso no controle de doenças pode ser atingido se as investigações forem dirigidas para o esclarecimento de como as infecções ocorrem e persistem na ausência da doença.

QUADRo 5.3 - Fatores relacionados a processos endêmicos 
Modificação nas condições determinantes de uma doença endêmica - como alterações ambientais, do hospedeiro ou de determinados agentes infecciosos - pode fazer dela uma doença epidêmica.

\section{TIPOS DE ESTUDOS EPIDEMIOLÓGICOS}

A fim de adquirir novos conhecimentos, os pesquisadores envolvidos em estudos epidemiológicos relativos à saúde pública e à clínica utilizam três estratégias principais: estudo de casos, pesquisa de laboratório e investigação populacional. A utilidade de tais estratégias, que são complementares entre si, se traduz na possibilidade de ver uma mesma condição segundo ângulos diferentes.

Para responder a perguntas habitualmente formuladas em epidemiologia, há duas técnicas principais: a realização de experiências e a realização de inquéritos. No caso da verificação de relações entre causa e efeito ou teste de eficácia de algum fármaco, o estudo mais indicado é o experimental. Para algumas questões mais simples, como conhecer a freqüência de dada condição, basta um inquérito de pequena duração e reduzida complexidade. Em muitas situações, no entanto, não será o melhor método aquele que pode ser utilizado, e sim um outro mais viável em virtude da natureza do problema ou das condições do momento.

A seguir, será apresentada uma visão mais aprofundada do que pode ser definido como estudo experimental e de um inquérito, para uma compreensão mais precisa das limitações e possibilidades de um e de outro.

O método experimental é a maneira mais adequada ao estudo de determinadas questões, como a eficácia e a segurança de vacinas e medicamentos, porque pode viabilizar o teste de uma prova diagnóstica, um programa educativo, uma conduta médica ou uma técnica cirúrgica. Por exemplo, a avaliação do impacto da suplementação nutricional de gestantes pode ser investigada por um método experimental em toda a extensão. Nesse tipo de estudo, são criadas condições especiais para se desenvolvê-lo em uma situação que requeira controle das diferentes condições que dificultam a interpretação dos resultados.

Todo modelo experimental é um estudo comparativo e prospectivo: formam-se, ao menos, dois grupos de indivíduos com características semelhantes - esse é um ponto essencial. Se os grupos diferem desde o início, a avaliação final ficará comprometida. Para formar grupos com as mesmas características usa-se um processo aleatório de separação de participantes; aqueles alocados no grupo experimental são submetidos ou expostos à intervenção proposta, enquanto os outros recebem tratamento habitual ou simplesmente 
placebo e permanecem como controles para termos de comparação. Todos os participantes são seguidos de modo semelhante durante algum tempo; quando possível, opta-se por uma avaliação duplamente cega, em que nem o avaliador nem o avaliado sabem a que grupo este pertence. Tal procedimento possibilita evitar a influência involuntária de sugestões ou impressões tendenciosas de ambos os lados: do pesquisador sobre o pesquisado e vice-versa.

Essa metodologia pode ser aplicada a comunidades inteiras, em vez de enfocar indivíduos. Os princípios gerais dos ensaios clínicos ou comunitários, de natureza preventiva ou curativa, são quase idênticos - pois adaptá-los a diferentes situações encontradas na prática exige pequenas variações.

Pode-se constatar com facilidade que poucas pessoas na área da saúde já participaram de estudos com características de um modelo experimental. No entanto, muitas já desenvolveram modelos de estudos do tipo inquérito. Há diversas explicações para isso. Uma é que problemas inerentes aos modelos experimentais, como os de natureza ética ou prática, podem torná-los impossíveis ou dificultar a realização.

\section{Estudos OBSERVACIONAIS}

Os estudos observacionais são aqueles em que a natureza se encarrega de ditar-lhes o curso; o investigador mensura os fenômenos que observa, mas não intervém neles. Incluem estudos que podem ser chamados de descritivos ou analíticos.

\section{Estudos observacionais descritivos}

Um estudo observacional descritivo limita-se a descrever a ocorrência de uma doença numa população e, com freqüência, é o primeiro passo em uma investigação epidemiológica. A propriedade desse tipo de estudo é apresentar uma informação descritiva limitada, como a que se verifica no estudo de relato ou de uma série de casos: as características de um número de pacientes com determinada doença são descritas, mas não comparadas entre si ou com população de referência. Isso estimula o desencadeamento de estudos epidemiológicos mais detalhados.

Todavia, mesmo se se considerar o caráter simplista dos estudos observacionais descritivos, os estudos epidemiológicos são analíticos pela natureza. Por exemplo, a descrição inicial do quadro clínico de quatro homens jovens com sintomas de uma pneumonia previamente caracterizada como rara motivou uma série de estudos epidemiológicos mais abrangentes, os quais conduziram ao entendimento de uma condição que ficou conhecida como AIDS. 


\section{Estudos observacionais analíticos}

Um estudo observacional analítico tem como propriedade ir além de um estudo descritivo, pois deve estabelecer relação entre o status de saúde e outras variáveis. Dentre as modalidades de estudos observacionais analíticos, destacam-se os estudos ecológicos, os seccionais, os do tipo caso-controle e os coortes.

Os ecológicos - ou correlacionais - são freqüentemente derivados de estudos que incluem processos epidemiológicos. Num estudo ecológico, as unidades de análise são populações ou grupos de indivíduos, ao invés de indivíduos isolados. Por exemplo, em dado país, foi demonstrada a relação entre ocorrência da venda de uma droga contra asma e ocorrência de aumento inesperado no número de morte de pacientes com crise asmática. Tal relação pode ser estudada com base na comparação entre populações de diferentes países ao mesmo tempo, ou de uma mesma população em intervalos temporais diferentes. Essa última abordagem pode evitar alguns dos fatores que introduzem erros por causa de diferenças socioeconômicas que representam problema potencial nos estudos ecológicos.

Os seccionais são empregados para se determinar a prevalência de uma doença; em razão disso, em geral são denominados de estudos de prevalência. Nesse tipo de estudo, as mensurações da exposição e do efeito são realizadas ao mesmo tempo. Não é fácil identificar razões para as associações demonstradas nos estudos seccionais. A questão crítica a ser respondida é se a exposição precede ou segue o efeito observado.

Os estudos do tipo caso-controle são relativamente simples, e de realização econômica. Muito utilizados para investigar causa de doenças, em especial as raras, incluem indivíduos com a doença de interesse e um apropriado grupo-controle de indivíduos não afetados por ela. A ocorrência de uma possível causa é estabelecida pela comparação entre os casos e os controles - daí serem longitudinais os estudos do tipo caso-controle, em contraste com os seccionais. Além disso, têm sido denominados de retrospectivos, pois a observação do investigador parte, retrospectivamente, da doença para uma possível causa. No entanto, esse termo pode induzir a erros porque "retrospectivo" e "prospectivo" são termos muito usados para descrever o tempo em que os dados são colhidos relativamente ao tempo atual. Dito isso, os estudos do tipo caso-controle podem ser tanto retrospectivos - quando todos os dados foram colhidos no passado - como prospectivos - quando os dados continuam a serem obtidos com o passar do tempo (Figura 5.5A).

Já os estudos coortes, também de incidência ou de seguimento, são aqueles que se iniciam com um grupo de indivíduos (o 
coorte) livre de determinada doença e classificados em diferentes subgrupos, conforme o grau de exposição a uma causa potencial de doença (Figura 5.5B).
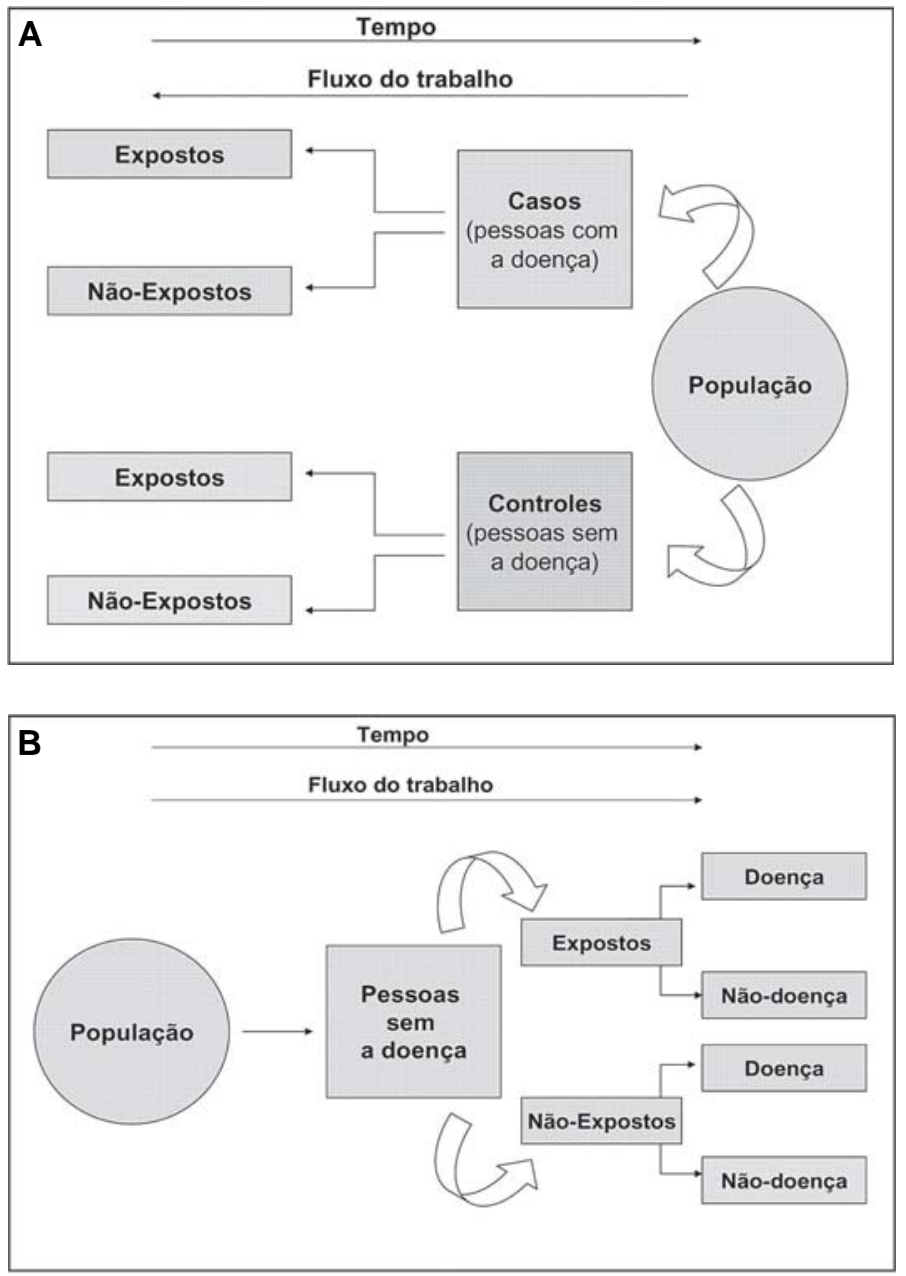

Figura 5.5 - Fluxograma comparativo dos estudos do tipo caso-controle (A) e coorte (B) utilizados como modelos de estudos.

Tanto na especificação e mensuração das variáveis de interesse quanto no desenvolvimento do estudo, observam-se como vão se comportar os números subseqüentes de novos casos da doença entre os diferentes grupos com ou sem exposição. Como os dados são coletados em intervalos diferentes, os estudos coortes são também longitudinais - como os estudos do tipo caso-controle. Embora tenham sido denominados de prospectivos, tal terminologia 
deve ser evitada, visto que pode provocar confusão; isso porque o termo "prospectivo" refere-se ao tempo em que os dados são coletados, e não à relação temporal entre causa e efeito. Assim, os estudos coortes podem ser tanto prospectivos como retrospectivos.

\section{ESTUDOS EXPERIMENTAIS OU INTERVENCIONAIS}

Os estudos experimentais ou intervencionais pressupõem participação ativa do investigador para modificar fatores determinantes, como grau de exposição, comportamento e progresso da doença, por meio de tratamento, por exemplo. Assemelham-se aos desenhos experimentais usados com freqüência nos estudos da área biomédica em geral e envolvem experimentos controlados e estudos de campo e de comunidade. No entanto, quando se tratar de projetos que envolvam seres humanos ou animais de experimentação, é preciso observar os princípios norteadores dos códigos de ética sobre pesquisa em seres humanos e em animais de laboratório (ver capítulo 3).

No que se refere ao desenho experimental, o de maior relevância é o estudo controlado randomizado; além desse, há estudos de campo e comunitários, nos quais os participantes são, respectivamente, indivíduos saudáveis e comunidades. Os estudos controlados randomizados são muito usados no estudo de novos medicamentos e procedimentos preventivos. Os indivíduos são alocados, de forma aleatória, em grupos, em geral, denominados de grupos tratados e controles, e a análise dos resultados se baseia nas observações encontradas nos dois ou mais grupos. As observações de interesse variam, mas fundamentalmente podem ser sintetizadas em progresso ou remissão da doença em estudo.

Os estudos de campo, em contraste com os estudos controlados, envolvem indivíduos livres de determinada doença. Como os indivíduos são livres da doença, o objetivo deve ser prevenir o aparecimento dela; se ocorrer, que seja em baixa freqüência. Para isso, tais estudos devem envolver considerável estrutura logística e recursos financeiros quando envolverem seres humanos. Um dos mais conhecidos estudos de campo usou o estudo da vacina Salk para prevenir a poliomielite e envolveu mais de um milhão de crianças.

Os estudos de comunidade são apropriados, em particular, ao estudo de doenças cuja origem reside nas condições sociais dos indivíduos e que podem ser influenciadas com mais facilidade diretamente no comportamento do grupo ou do indivíduo - as doenças cardiovasculares exemplificam bem uma condição apropriada a estudos de comunidade. Todavia, pode limitar esse tipo de estudo a impossibilidade de nem todas as comunidades serem incluídas, porque seria impraticável uma alocação aleatória dos indivíduos. 


\section{ERROS POTENCIAIS EM ESTUDOS EPIDEMIOLÓGICOS}

Há muitas possibilidades de erro em estudos e empregos de métodos epidemiológicos que levam a conclusões falsas. Como não podem ser eliminados, deve-se investir na minimização deles e analisar sua importância. Os erros podem ser classificados em randômicos (ao acaso) ou sistemáticos (vício).

1. Erro randômico (aO ACASO) é a divergência dos dados de uma amostra do valor verdadeiro da população em virtude apenas do acaso.

Há três fontes principais de erros ao acaso: variação biológica individual, de amostragem e de aferições. A variação biológica individual sempre ocorre em estudos de uma amostra da população e leva a determinações nem sempre precisas. Aferições sistemáticas e cuidadosas de exposição e efeito podem reduzir as variações individuais e os erros de aferições. Erro de amostragem ocorre como parte do processo de seleção dos participantes do estudo, já que representam uma amostra de uma população maior. Tais erros podem ser minimizados pela utilização de amostras de tamanho adequado.

O erro ao acaso pode ser do tipo I, ou erro $\alpha$ - ocorre quando se conclui que existe diferença significativa e, na realidade, ela não existe; e do tipo II, ou erro $\beta$-ocorre quando se conclui que não há diferença significativa quando, na realidade, ela existe (Quadro 5.4).

A probabilidade de haver o erro á é expressa pelo valor de $P$, que representa o nível de significância estatística, ou seja, a probabilidade aceita pelo pesquisador de se cometer o erro á. Assim, o valor de á pode ser arbitrariamente fixado em $5 \%$ (probabilidade de a diferença encontrada ter sido ao acaso é menor que $5 \%$ ) ou $1 \%$ (menor probabilidade de ocorrer o erro á). Entretanto, quanto menor for o valor de á, maior será a probabilidade de ocorrer o erro $\beta-$ a menos que o tamanho da amostra seja adequadamente aumentado. Portanto, esses três elementos (tamanho da amostra, erro á e erro $\beta$ ) estão intrinsecamente relacionados e são influenciados por qualquer alteração em um dos valores.

Em geral, a probabilidade de ocorrer o erro $\beta$ não é previamente estabelecida e referida no texto; mas é quase sempre superior à probabilidade fixada ou aceitável para o erro á. $O$ erro $\beta$ pode ser minimizado aumentando-se o número de casos do estudo e se vincula ao poder do teste; noutros termos, a probabilidade de os resultados ou as conclusões do estudo serem verdadeiramente negativos é maior. 


\begin{tabular}{|ccc|}
\hline $\begin{array}{c}\text { Resultado } \\
\text { do } \\
\text { Estudo }\end{array}$ & \multicolumn{2}{c|}{ Resultado real } \\
\cline { 2 - 3 } & $\begin{array}{c}\text { Não há } \\
\text { diferença } \\
\text { significativa }\end{array}$ & $\begin{array}{c}\text { Há } \\
\text { diferença } \\
\text { significativa }\end{array}$ \\
\hline $\begin{array}{c}\text { Não há } \\
\text { diferença } \\
\text { significativa }\end{array}$ & $\begin{array}{c}\text { Decisão } \\
\text { correta }\end{array}$ & $\begin{array}{c}\text { Erro tipo II } \\
\text { (erro } \boldsymbol{\beta} \text { ) }\end{array}$ \\
$\begin{array}{c}\text { Há diferença } \\
\text { significativa }\end{array}$ & $\begin{array}{c}\text { Erro tipo I } \\
(\text { erro } \boldsymbol{\alpha})\end{array}$ & $\begin{array}{c}\text { Decisão } \\
\text { Correta }\end{array}$ \\
\hline
\end{tabular}

QuAdro 5.4 - Possibilidades de erros na análise dos resultados de estudos

Os erros $\alpha$ e $\beta$ podem ser também discutidos no contexto dos testes de hipóteses, por exemplo, no que se refere à aceitação ou rejeição da hipótese de nulidade (Quadro 5.5) - como será discutido nos capítulos 6 e 10.

\begin{tabular}{|ccc|}
\hline Decisão & Verdadeira & Falsa \\
\hline $\begin{array}{c}\text { Aceitar } \\
\text { Rejeitar }\end{array}$ & $1-\beta$ & $\beta$ \\
\end{tabular}

QUADRo 5.5 - Comparação entre os erros de primeira e segunda espécie ( $\alpha$ e $\beta$, respectivamente) em relação à aceitação e rejeição da hipótese de nulidade $\left(\mathrm{H}_{0}\right)$

2. ERRo sistemático (vício) é a tendência a produzir resultados que diferem dos valores verdadeiros, de um modo sistemático.

Erro sistemático é um problema particular em estudos epidemiológicos sem controle sobre os participantes estudados - ao contrário do que se observa em experimentos laboratoriais. Algumas variáveis epidemiológicas são difíceis de determinar (tipo de personalidade, consumo de álcool, exposições prévias a diferentes condições ambientais) e, assim, levam ao erro sistemático.

Dentre as diversas fontes de erros sistemáticos, pode-se destacar a variação biológica individual, o viés de seleção e o viés de aferições. A variação biológica individual sempre ocorre em estudos de uma amostra da população e levam a conclusões nem sempre precisas. O viés de seleção ocorre quando há diferença sistemática entre as características dos indivíduos selecionados para o estudo e as características daqueles que não foram - por exemplo, indivíduos que aceitam participar de um estudo sobre os efeitos do tabagismo e diferem, quanto aos hábitos de fumar, dos que não aceitam, os quais, em geral, são fumantes contumazes. 
Isso é evidente em estudos epidemiológicos ocupacionais, em que há o "efeito do trabalhador saudável": só trabalhadores saudáveis permanecem no emprego para realizar suas tarefas; os doentes e incapazes são excluídos. Assim, estudos de prevalência nesses locais sobre a associação entre determinada exposição/causa (por exemplo, formaldeído) e efeito (irritação dos olhos) podem levar a conclusões errôneas.

Estudos em epidemiologia clínica, também, podem apresentar esse tipo de erro. Tome-se este exemplo: um novo esquema de medicamentos para tratar determinada doença mostrou eficácia maior ( $50 \%$ de óbito) em relação ao tratamento convencional $(75 \%$ de óbito); entretanto, essa superioridade poderia resultar de um viés de seleção se os pacientes que receberam o esquema novo fossem menos graves (resposta melhor) do que os que receberam o esquema tradicional (resposta pior). Portanto, se os indivíduos participantes de um grupo de estudo mostrarem diferentes associações daqueles do grupo-controle, ocorrerá uma estimativa tendenciosa da associação entre exposição/causa e efeito. Logo, o viés de seleção ocorre como parte do processo de seleção dos participantes do estudo, pois estes representam uma amostra de uma população maior. Tais erros podem ser minimizados pelo uso de amostras de tamanho adequado.

O viés de aferições ocorre quando as mensurações individuais são imprecisas, ou seja, quando não medem de modo correto o que deveriam medir. Há várias fontes de tais tendências, a exemplo de determinações bioquímicas ou fisiológicas que apresentam diferentes resultados da mesma amostra entre diferentes laboratórios. Se as amostras dos grupos expostos e controles são analisadas aleatoriamente por diferentes laboratórios, então os erros serão ao acaso; se as amostras do grupo exposto são analisadas em um laboratório, enquanto as amostras do grupo controle são analisadas em outro e produzem resultados sistematicamente diferentes, então a avaliação será tendenciosa. Aferições sistemáticas e cuidadosas de exposição e efeito podem reduzir as variações individuais e os erros de aferições.

O fator de confundimento ("confounding factor") ou fator de confusão, também, fornece estimativas errôneas do efeito, mas não é estritamente um tipo de erro ou viés, por não resultar de erro sistemático no desenho do estudo. Ele se origina porque a distribuição não aleatória de fatores de risco na população de origem também ocorre na população em estudo. Esse fator será abordado com mais detalhes no capítulo 7 ao se tratar dos métodos de análise em estudos sobre causalidade. 


\section{EXATIDÃo E PRECISÃo}

Para melhor entender se a divergência ou variação dos resultados de um estudo dos valores verdadeiros resultou de erro randômico (ao acaso) ou erro sistemático (por vício), é fundamental observarem-se as definições de exatidão e precisão nesse contexto.

\section{Exatidão versus Precisão}

- Exatidão: é a capacidade do método de fornecer resultados próximos do valor verdadeiro.

- Precisão: é a capacidade do método de fornecer resultados reprodutiveis entre si.

Um método de aferição pode ser preciso e não ser exato, e vice-versa. Os diagramas apresentados na Figura 5.6 ilustram as possibilidades de diferentes graus de exatidão e precisão: ter baixa exatidão e baixa precisão (Fig. 5.6A); ser preciso e não ser exato (Fig. 5.6B); ser exato e não ser preciso (Fig. 5.6C); ser de alta precisão e alta exatidão (Fig. 5.6D).

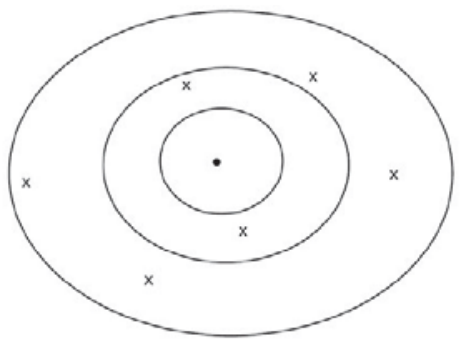

(A) baixa exatidão e baixa precisão
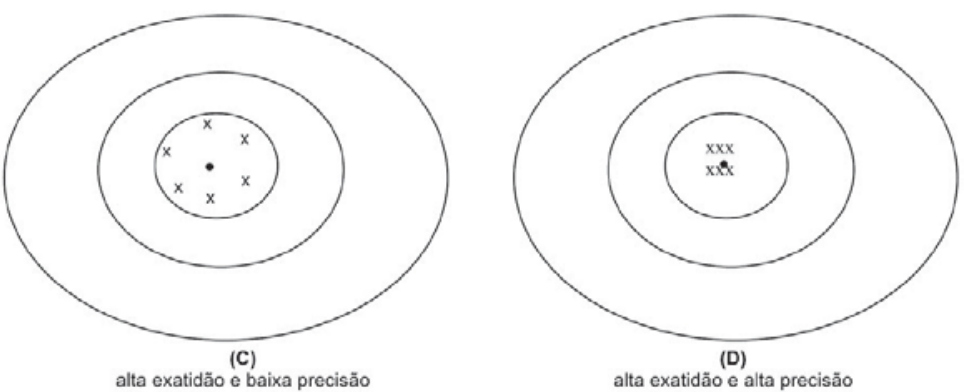

FIgURA 5.6. Diagramas representativos de exatidão e precisão.

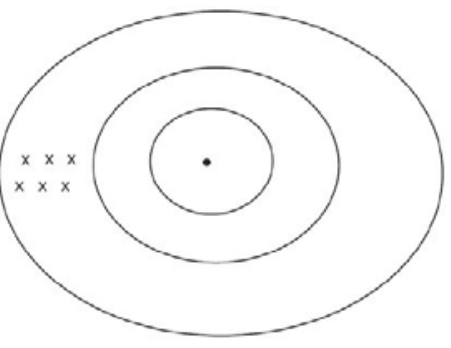

(B)

baixa exatidão e alta precisāo

alta exatidão e alta precisão 


\section{CONCLUSÃO}

Como se pode depreender dos temas abordados aqui, o uso de métodos epidemiológicos pode ajudar a responder questões fundamentais:

- se, quando se verifica a existência da associação entre um fator e distúrbios na saúde, essa observação significa que este fator é causa da doença;

- se a gravidade da doença varia com o grau de exposição a este fator;

- se se considerar este grau de associação, quais procedimentos devem ser implementados pelos indivíduos e pelos serviços de saúde pública;

- se os achados de um estudo epidemiológico valorizam o pânico ou uma resposta calculada;

- e o quão aplicáveis são os achados para outros estudos que venham a ser posteriormente conduzidos.

Assim, a epidemiologia é uma disciplina que descreve, quantifica e postula os mecanismos interferentes no processo saúde-doença das populações. A correta utilização dos métodos epidemiológicos se constitui em poderosa ferramenta para o estudo das várias abordagens desse processo.

\section{REFERÊNCIAS}

BERQUÓ, E. S.; SOUZA, J. M. P. de; GOTLIEB, S. L. D. Bioestatística. São Paulo: Pedagógica Universitária, 1981. 350p.

BEAGLEHOLE, R.; BONITA, R.; KJELLSTRÖM, T. Basic epidemiology. Geneva: World Health Organization, 1994. 175p.

FLETCHER, R. H.; FLETCHER, S. W.; WAGNER, E. H. Clinical epidemiology: the essentials. 3rd ed. Baltimore: Williams and Wilkins, 1996. 276p.

FRANÇA-SILVA, J. C. et al. Epidemiology canine visceral leishmaniosis in the endemic area of Montes Claros municipality, Minas Gerais States, Brazil. Veterinary Parasitology, Amsterdan, v. 111, n. 2, p. 161-173, Feb. 2003.

FRIIS, R. H.; SELLERS, T. A. Epidemiology for public health practice. 3rd ed. Gaithersburg: Aspen, 2004. 504p.

GARFIELD, E. Quantitative analysis of the scientific literature and its implications for science policymaking in Latin America and the Caribbean. Bulletin of the Pan American Health Organization, Geneve, v. 35, p. 87-95, 1995. 
JORGE, M. T.; RIBEIRO, L. A. Fundamentos para o conhecimento científico. São Paulo: Baliero, 1999. 106p.

SEVERINO, A. J. Diretrizes de uma monografia científica. In: Metodologia do trabalho científico. 22. ed. rev. ampl. São Paulo: Cortez, 2002. p. 73-132. 
6.

\title{
CONCEITOS BÁSICOS DE BIOESTATÍSTICA
}

\author{
Geraldo Sadoyama Leal \\ Deise Aparecida de Oliveira Silva \\ Mônica Camargo Sopelete
}

\section{INTRODUÇÃO}

A estatística é uma ciência exata que estuda desde a coleta, a organização, a análise, até a interpretação dos dados para testar uma hipótese ou, de maneira mais geral, estimar uma quantidade. Mediante técnicas estatísticas apropriadas a cada estudo, a estatística permite que se façam inferências de uma certa população; para tanto, toma-se uma pequena amostra desta a fim de se submetê-la à analise, que fornecerá até o possível erro da estimativa dessa inferência.

O objeto de estudo da estatística são os fenômenos que envolvem populações formadas por elementos que apresentam semelhanças entre si no que se refere a certos atributos e diferenças em relação a outros. Segundo definição encontrada no dicionário Aurélio, a palavra "estatística" designa "[...] o método que objetiva o estudo dos fenômenos de massa, isto é, os que dependem de uma multiplicidade de causas, e tem por fim representar, sob forma analítica ou gráfica, as tendências características limites desses fenômenos. [...]" (ESTATíSTICA, 1986, p.717). A idéia básica da estatística é simples: pelos dados coletados, inferir conclusões generalizadas acerca da população a que eles se referem. Para isso, foram desenvolvidos métodos baseados em um modelo simples: assumir que uma população infinitamente grande de valores existe e que suas amostras foram selecionadas de tal população de forma randômica. Dessa forma, a estatística e a teoria das probabilidades procuram fornecer ferramentas e técnicas quantitativas para o tratamento das populações, permitindo sua descrição e a obtenção de suas propriedades.

Quase todas as áreas do conhecimento requerem algum uso da estatística e da teoria das probabilidades - desde as ciências físico-químicas, passando pelas ciências da vida, até as ciências sociais. Portanto, é importante que os profissionais atuantes nessas áreas dominem, pelo menos, os conceitos elemen- 
tares e tenham alguma habilidade operacional com a estatística, a fim de que possam desempenhar suas funções com um mínimo de autonomia e compreensão dos elementos estatísticos utilizados.

\section{POPULAÇÃO E AMOSTRA}

População são casos, dados, objetos ou grupos de pessoas que apresentam característica comum observável. Seu tamanho, em geral, é expresso pela letra $N$ (maiúscula). Como muitas vezes o estudo de uma população inteira é inviável ou impraticável, a análise de amostras representativas e o emprego de métodos estatísticos apropriados a cada caso permitem fazer inferências que convirjam para conclusões sobre determinada população - representada por uma amostra.

Nesse sentido, amostra é um subgrupo ou parte de uma população e deve representar qualitativa e quantitativamente o todo de que foi extraída (Figura 6.1). Para tanto, ela deve se pautar em dois princípios básicos da estatística inferencial: 1) ser grande o suficiente; 2 ) serem seus constituintes selecionados de modo randômico (ao acaso). É importante notar que a amostra pode ser usada para se obter informação acerca de toda a população estudada.

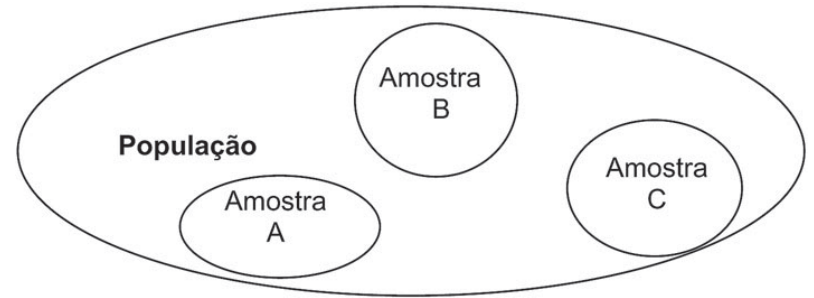

Fıgura 6.1 - População e amostras

Características de uma população que diferem de um indivíduo para outro e motivam estudos são chamadas variáveis. Exemplos de variáveis são comprimento, massa, idade, temperatura, número de ocorrências, etc. Cada unidade (membro) da população escolhida como parte da amostra fornece medida de uma ou mais variáveis: são as observações.

Aqui, duas perguntas são freqüentes: 1) por que não se estuda uma população inteira? Há muitas razões para isso; por exemplo: alto custo e o tempo prolongado necessário à obtenção de informações da população inteira, como um eventual estudo de todos os indivíduos com viroses no planeta Terra; 2) que tamanho deve ter a amostra para assegurar resultados significativos? A amostra a ser coletada deve ser o maior possível, mas vale ressaltar 
que, muitas vezes, a representatividade da população estudada é mais importante que o tamanho.

Existem alguns fatores determinantes do tamanho de uma amostra - embora nenhum deles tenha relação direta com o tamanho da população. São eles:

1) grau ou intervalo de confiança adotado;

2) máximo erro permissível;

3) variabilidade da população.

Uma fórmula de cálculo conveniente para determinar o tamanho amostral n é:

$$
\mathrm{n}=\left(\frac{\mathrm{Z} \cdot \mathrm{s}}{\mathrm{E}}\right)^{2}
$$

onde:

E é o erro permissível;

$\mathbf{Z}$ é o valor de $t$ de Student para diferentes intervalos de confiança adotados;

s é o desvio padrão da amostra.

Para se obterem valores de $Z$ em relação aos diferentes graus de confiança, tem-se que recorrer à seguinte tabela (Tabela 6.1):

TABELA 6.1 - Distribuição dos valores de $t$ de Student, padronizados para uma distribuição normal, em função de diferentes intervalos de confiança

\begin{tabular}{cc}
\hline Intervalo de confiança (\%) & $\mathbf{Z}$ \\
\hline 90 & 1,6448 \\
95 & 1,96 \\
97,5 & 2,2414 \\
99 & 2,5758 \\
99,5 & 2,807 \\
\hline
\end{tabular}

Considere-se o exemplo a seguir. Deseja-se estimar a média de gasto mensal em remédios de uma família de classe baixa por mês. Com base em estudos similares, o desvio padrão é estimado em $\mathrm{R} \$ 20$. O intervalo de confiança almejado é de $99 \%$, com um erro máximo admissível de $\mathrm{R} \$ 5$. Assim, qual deve ser o tamanho da amostra estudada?

$$
\mathrm{n}=\left(\frac{(2,58) \mathrm{x}(20)}{5}\right)^{2}=106,50 \cong 107
$$

A fórmula para determinar o tamanho amostral no caso de estimativa de proporções é:

$$
\mathrm{n}=\overline{\mathrm{p}}(1-\overline{\mathrm{p}})\left(\frac{\mathrm{z}}{\mathrm{E}}\right)^{2}
$$


onde:

$\overline{\mathbf{p}}$ é a proporção estimada, baseada na experiência passada ou em amostra-piloto;

$Z$ é o valor de $t$ de Student para diferentes intervalos de confiança adotados;

E é o máximo erro permissível que o pesquisador tolera.

Considere-se o seguinte exemplo: um hospital deseja estimar a proporção de crianças que têm um cateter vascular central. Se o hospital deseja que a estimativa se afaste, no máximo $3 \%$ da proporção populacional, quantas crianças devem conter a amostra? Assumindo um intervalo de confiança de $95 \%$ e que o hospital estimou, com base em experiência anterior, que quase $30 \%$ das crianças têm um cateter vascular central:

$$
\mathrm{n}=(0,30)(0,70)\left(\frac{1,96}{0,03}\right)^{2}=893,4 \cong 893
$$

Foram apresentadas aqui apenas duas formas de se calcular o tamanho da amostra. Entretanto, várias fórmulas estão disponíveis, e a escolha se baseará na medida estimada que se quer comparar (média, porcentagem, prevalência ou limiar de detecção) e no tipo de estudo (caso-controle ou coorte).

O programa computacional Win Episcope 2.0 permite que se faça o cálculo do tamanho amostral conforme as diferentes medidas de comparação entre grupos e tipos de estudo. Esse programa pode ser obtido, na forma freeware, no seguinte endereço eletrônico: $<$ http://www.clive.ed.ac.uk/winepiscope/>

Após definir o tamanho amostral representativo, deve-se considerar como tomar uma amostra, ou seja, como realizar uma amostragem. Existem várias formas, e dentre elas as mais tradicionais são:

a) amostragem aleatória ou randomizada (ao acaso): cada um dos componentes da população estudada tem a mesma chance de ser incluído na amostra, pois é selecionado de forma independente, o que implica que a inclusão particular de um membro não altera a chance de inclusão dos demais. Se isso não ocorrer, dizse que a amostra é não randomizada ou viciada. Para a seleção de uma amostra randomizada, pode-se utilizar números aleatórios, que são obtidos em tabelas apropriadas ou por meio de planilhas eletrônicas (Figura 6.2). 


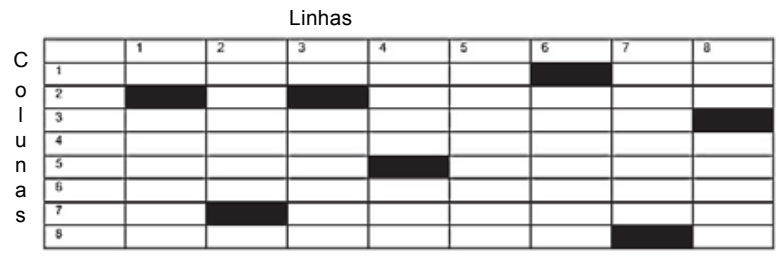

Figura 6.2 - Amostragem aleatória

b) amostragem sistemática: trata-se de uma variação de amostragem simples ao acaso, muito conveniente quando a população já está ordenada, como nas listas telefônicas, nos arquivos em ordem alfabética em um computador, nas fichas em um fichário, etc. (Figura 6.3).

Linhas

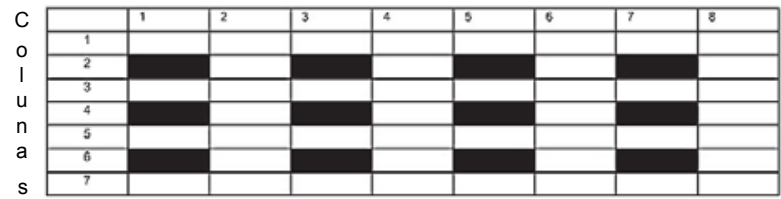

Figura 6.3-Amostragem sistemática

c) amostragem estratificada: estratificar uma população é subdividi-la em subpopulações denominadas estratos e mutuamente exclusivas; em cada estrato seleciona-se uma amostra aleatória de cada subpopulação (Figura 6.4).

Linhas

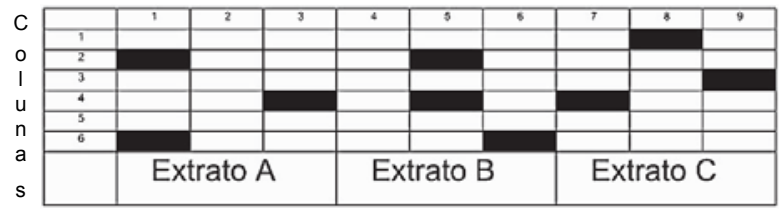

FiguRA 6.4-Amostragem extratificada

\section{TIPOS DE VARIÁVEIS}

Como foi dito, variáveis são características de uma população que diferem de um indivíduo para outro e suscitam estudos. Podem ser representadas por valores numéricos (variáveis quantitativas) ou por atributos/categorias (variáveis qualitativas).

As variáveis quantitativas podem ser contínuas ou descontínuas:

- contínuas: os valores das observações podem aumentar 
ou diminuir de quantidades infinitamente pequenas ou infinitamente grandes. Este tipo de dado pode ser trabalhado para gerar informações que expressem a tendência central e a dispersão. Não existe um limite nítido entre os valores. Ex.: peso, volume, comprimento, estatura, etc. Na realidade valores intermediários dessas medidas estão condicionados à precisão dos seus respectivos aparelhos de medida ou aferição.

- descontínuas ou discretas: os valores das observações só podem aumentar ou diminuir de uma quantidade fixa e determinada. Podem assumir apenas valores inteiros, sem intermediários possíveis, e há um limite nítido entre os valores - a exemplo do número de estruturas (dentes, glândulas), colônias de microorganismos em uma placa de Petri, indivíduos por unidade médica, etc.

As variáveis qualitativas - também chamadas de categóricas ou de atributos - constituem um tipo especial de variável discreta que não pode ser medida, mas pode ser expressa em termos qualitativos, através da separação em subconjuntos mutuamente exclusivos. Podem ser codificadas em valores numéricos ou combinadas com freqüências e, assim, submetidas a tratamento estatístico - aqui se incluem, dentre outras, sexo (masculino ou feminino), cores (verde ou amarelo), grupos de um sistema sangüíneo $(A, B$, $A B, O$ ), etc. No caso do sistema sanguíneo $A B O$, pode-se representar os quatro grupos sanguíneos por 1, 2, 3 e 4, respectivamente, ou mesmo tratá-los estatisticamente pela freqüência (porcentagem) com que aparecem em determinada população e compará-los entre si, ou com outra população em estudo. No caso do sexo, pode-se representar, de modo arbitrário, o feminino, por exemplo, pelo numeral 0 (zero) e o masculino pelo 1 (um).

As variáveis qualitativas podem ser classificadas em ordinais - existe uma ordem lógica na medição, como notas, altura, etc. - e nominais - a variável é classificada pela qualidade que tem, e não por alguma medição numérica, a exemplo de sexo, raça, evolução clínica de um paciente (morte ou sobrevivência), etc.

\section{MEDIDAS DE TENDÊNCIA CENTRAL}

As três medidas de tendência central mais comuns são: média, mediana e moda. Há vários tipos de média (aritmética, geométrica, harmônica, quadrática, cúbica, entre outras). A média aritmética, a mais usada, é obtida pela soma de todos os valores de uma distribuição dividida pelo número total de valores da distribuição. 


$$
\begin{aligned}
& \text { Partie II - Tipos de Estudos e Metodologia Estatística } \\
& \overline{\mathrm{x}}=\frac{\mathrm{x}_{1}+\mathrm{x}_{2}+\mathrm{x}_{3}+\ldots+\mathrm{x}_{\mathrm{n}}}{\mathrm{n}}
\end{aligned}
$$

onde:

$x_{1}$ a $x_{n}=$ observações da distribuição;

$\mathrm{n}$ = número de observações da distribuição.

A média é habitualmente representada por $\bar{x}$ (amostral) ou $\mathrm{m}$ (populacional).

A mediana (Md) é o valor central de uma distribuição ou de um conjunto de valores, quando eles são dispostos em ordem de magnitude (crescente ou decrescente), ou seja, $50 \%$ dos valores estão acima da mediana e 50\%, abaixo. Se houver número ímpar de valores ordenados, a mediana será o valor que ocupa a posição central; se a distribuição tiver número par de elementos, isto é, se não houver valor central, a mediana é a média aritmética entre os dois valores centrais.

Por exemplo, considere-se esta distribuição de massas de dez recém-nascidos:

$$
2,1-2,8-2,9-3,0-3,1-3,2-3,2-3,2-3,5-4,0(\mathrm{Kg})
$$

Como o número de observações é par, a mediana é $\mathrm{Md}=$ $(3,1+3,2) / 2=3,15$.

A moda (Mo) é o valor amostral de maior freqüência encontrado em uma distribuição. Como exemplo, veja-se esta turma de seis alunos com alturas:

$$
1,50-1,60-1,60-1,60-1,70-1,80(m) .
$$

A moda de altura é Mo $=1,60 \mathrm{~m}$.

A moda é útil para nos dar uma noção geral da distribuição.

As medidas de tendência central sintetizam o conjunto de dados em um único número. Procura-se definir um valor que represente bem a distribuição da variável de interesse. Para expressar um valor típico da distribuição, em geral usa-se a média ou a mediana. Se a distribuição é simétrica (Figura 6.5), as duas medidas terão valores muito semelhantes. Se a distribuição apresentar valores muito extremos, a mediana será uma medida de tendência central mais adequada do que a média, pois não é influenciada por valores extremos (Figura 6.6). Não é exatamente a amplitude da amostra que define o uso da média ou mediana, mas sim o modo como os elementos dessa amostra se distribuem nela. 
Considerem-se as seguintes distribuições:

$\begin{array}{lllllllll}\text { Ex. } 1: 1 & 2 & 2 & \mathbf{4} & 7 & 10 & 15 & & \text { mediana }=4 \text { e média }=5,85 \\ \text { Ex. 2: } 1 & 1,6 & 2 & \mathbf{2 , 4} & 3 & 3,2 & 4 & \text { mediana }=2,4 \text { e média }=2,45\end{array}$

O primeiro exemplo é de uma distribuição assimétrica, e a mediana divide a distribuição ao meio, com $50 \%$ das observações acima da mediana e $50 \%$ abaixo. Já no segundo exemplo, como a distribuição é bastante simétrica, usa-se a média. A mediana é, como esperado, muito próxima dessa média.

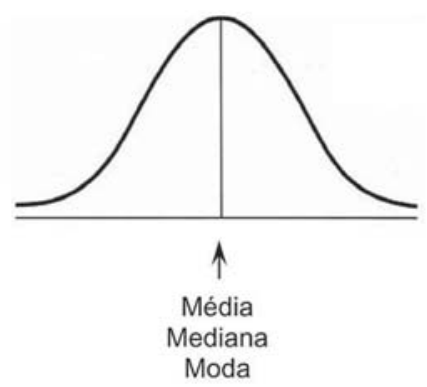

FIgURA 6.5 - Distribuição simétrica

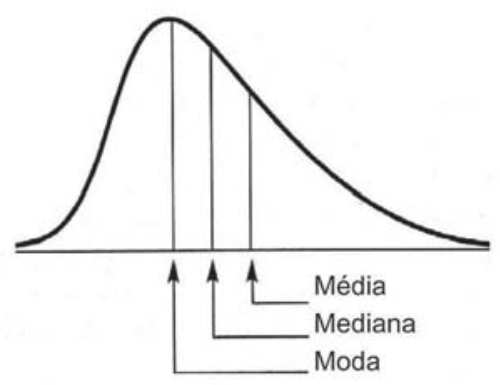

Figura 6.6 - Distribuição assimétrica

Quando usar média ou mediana?

A média só pode ser utilizada em variáveis quantitativas, e a mediana, em variáveis quantitativas e qualitativas ordinais. Embora seja indicada para variáveis quantitativas, a média pode induzir a erro no caso de a amostra analisada ter valores muito extremos. A mediana também é indicada quando difere muito da média; nesse caso aconselha-se tomar a mediana como medida de tendência central.

\section{MEDIDAS DE DISPERSÃO}

Medidas de dispersão são aquelas de tendência central que sugerem uma idéia da variação dos dados. As mais comuns são a variância, o desvio padrão e a amplitude (intervalo de variação). Para variáveis ordinais, bem como qualitativas em que não é possível calcular médias ou desvios padrão, a dispersão pode ser calculada com base na amplitude interquartil (diferença entre o terceiro e o primeiro quartil) e no desvio quartil (metade da amplitude interquartil). Medidas de tendência central como a média devem ser acompanhadas das respectivas medidas de dispersão. 
A variância e o desvio padrão indicam melhor a variabilidade de uma distribuição que a amplitude, pois consideram todos os valores da distribuição para seus cálculos. Já a amplitude total (range, também intervalo de variação) só considera os valores mais extremos. Em outras palavras, a variância e o desvio padrão discriminam melhor a variação porque duas distribuições podem apresentar valores muito diferentes no que se refere à dispersão, mas com valores extremos (maior e menor) exatamente iguais. A variância objetiva avaliar o quanto os valores de uma distribuição estão dispersos em relação ao valor da média; ou seja, ela é a média quadrática das discrepâncias da distribuição em relação à média. A variância $\left(\mathrm{s}^{2}\right)$ pode ser calculada para a população ou para uma amostra.

$$
\sigma^{2}=\frac{\sum(X-\mu)^{2}}{n \text { (população)ou } n-1(\text { amostra })}
$$

onde:

$\mathrm{X}=$ valor observado;

$\mu=$ média dos valores observados;

$\mathrm{n}=$ número de observações da distribuição.

Assim, para se obter o valor da variância, basta que se calcule a discrepância de cada valor em relação à média. Para tanto, é preciso subtrair cada valor da distribuição $(x)$ da média da distribuição $(\mu)$, elevar cada resultado ao quadrado e somar os resultados. Após isso, é só dividir pelo tamanho da amostra menos $1(\mathrm{n}-1)$. Caso se esteja lidando com uma população, a soma dos resultados deve ser dividida por $\mathrm{n}$.

O desvio padrão (s) é uma medida vinculada à variância. Ambos medem a dispersão dos dados da distribuição no que se refere à média. Para se obter uma medida de dispersão expressa na unidade original (visto que no cálculo da variância eleva-se ao quadrado para se eliminar o sinal negativo), deve-se extrair a raiz quadrada da variância, obtendo assim o desvio padrão.

$$
\sigma=\sqrt{\frac{\sum(\mathrm{X}-\mu)^{2}}{\mathrm{n}}}
$$

O desvio padrão é uma forma de representar a dispersão dos dados ao redor da média. Se os dados se comportarem de acordo com uma população de distribuição normal, eles se distribuirão simetricamente ao redor da média.

Os cálculos das medidas de dispersão são exemplificados com dados hipotéticos da Tabela 6.2. 
TABELA 6.2 - Massa corporal de onze estudantes de medicina

\begin{tabular}{ccc}
\hline Massa (Kg) & $(\mathbf{x}-\mu)$ & $(\mathbf{x}-\mu)^{\mathbf{2}}$ \\
\hline 70 & $70-82=-12$ & 144 \\
72 & $72-82=-10$ & 100 \\
75 & $75-82=-7$ & 49 \\
78 & $78-82=-4$ & 16 \\
80 & $80-82=-2$ & 4 \\
82 & $82-82=0$ & 0 \\
85 & $85-82=3$ & 9 \\
88 & $88-82=6$ & 36 \\
90 & $90-82=8$ & 64 \\
91 & $91-82=9$ & 81 \\
92 & $92-82=10$ & 100 \\
$\Sigma=903$ & $\Sigma(x-\mu)=1$ & $\Sigma(x-\mu)^{2}=603$ \\
\hline
\end{tabular}

onde:

$\mathrm{x}=$ massa corporal;

$\mu=$ média;

$\mathrm{n}$ = número de observações;

$\therefore \mathrm{n}=11$ e $\mathrm{m}=903 / 11=82$;

$\Sigma(x-\mu)^{2}=603$;

$\sigma^{2}$ é a variância $\therefore \sigma^{2}=603 / 11=54,82$;

$\sigma$ é o desvio padrão $\therefore \sigma=\sqrt{54,82}=7,4$;

amplitude $=92-70=22$.

O chamado coeficiente de variação expressa o desvio padrão como porcentagem do valor da média, portanto independe da unidade de medida usada.

Coeficiente de variação (\%) = desvio-padrão/média x 100

Um coeficiente de variação igual a $100 \%$ indica que o desvio padrão é igual à média; quanto menor for ele, mais homogênea será a amostra. $O$ uso desse coeficiente permite que se comparem dispersões de dados entre estudos que usaram unidades de medida diferentes - por exemplo, polegadas e centímetros.

$\mathrm{Na}$ prática, observa-se que a média calculada para uma amostra dificilmente será igual à média (real) da população. $\mathrm{O}$ tamanho da discrepância depende do tamanho da amostra e da variabilidade dos dados: médias baseadas em grande número de casos podem variar menos que as que se baseiam em pequeno número, e médias de populações com pequena variabilidade podem variar menos que aquelas de grande variabilidade. 
Assim, verifica-se que essas médias têm uma distribuição normal em torno da média verdadeira e que o desvio padrão dessa população de médias - chamado erro padrão da média - é menor que os desvio padrão obtidos com base nas amostras isoladas e pode ser obtido pela seguinte fórmula:

$$
\sigma_{\mathrm{x}}=\sigma / \sqrt{\mathrm{n}}
$$

onde:

$\sigma_{\mathrm{x}}=$ erro padrão da média;

$\sigma=$ desvio padrão fornecido pela amostra;

$\mathrm{n}$ = tamanho da amostra.

O erro padrão da média $\left(\sigma_{x}\right)$ mede o grau de dispersão das médias de diferentes amostras de mesmo tamanho extraídas de uma mesma população, em torno da média das médias, ou seja, da média verdadeira da população estudada. O erro padrão apresenta uma relação inversa com o tamanho da amostra: quando o tamanho aumenta, o erro padrão diminui.

Tomando-se os dados apresentados na Tabela 6.5 como exemplo, onde $n$ é igual a 11 e $\sigma=7,4$, obtém-se um $\sigma_{x}=2,22$.

\section{Teorema do limite central}

No estudo de amostras com 100 ou mais elementos, mesmo para uma distribuição que apresenta determinado viés, a distribuição das médias dessas amostras se aproxima da distribuição normal. Em outras palavras, com base no estudo de áreas sob a curva normal (Figura 6.7), é possível determinar a probabilidade de a diferença entre as médias da amostra e da população ter ocorrido ao acaso, e não por alguma característica que as diferencie.

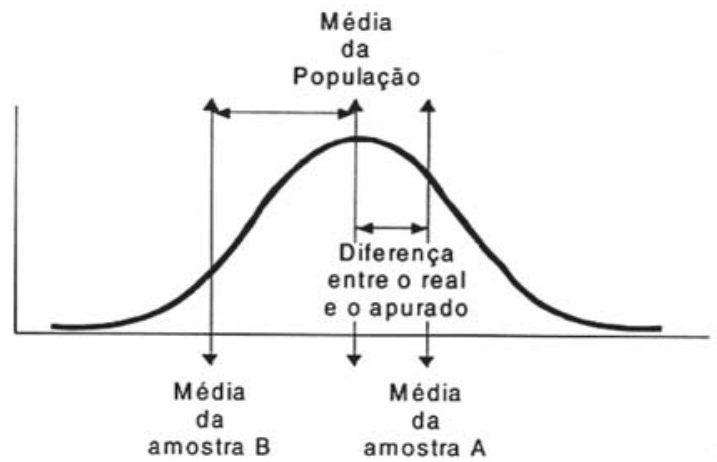

Fıgura 6.7 - Discrepâncias entre as médias de diferentes amostras da mesma população 


\section{TIPOS DE DISTRIBUIÇÃO DE FREQÜÊNCIA}

Quando se trabalha com variáveis discretas, os elementos que constituem as amostras, por si só, representam classes distintas. Assim, o modo como essas variáveis se distribuem será analisado segundo sua freqüência absoluta (número total de observações) ou relativa (porcentagem ou números decimais), e os tratamentos estatísticos serão realizados comparando-se essas freqüências nos diferentes grupos estudados.

Os dados agora agrupados em classes poderão ser apresentados em forma de tabela ou mesmo de gráficos (histograma ou polígono de freqüências), de forma a indicar as respectivas freqüências (absoluta e/ou relativa) e a relevância estatística. A descrição gráfica das distribuições de freqüências é importante porque dá uma idéia de como se distribuem os dados amostrais (simétrica ou assimetricamente) e permite uma análise da heterogeneidade da amostra, pois duas ou mais modas são indicativas de populações diferentes.

No histograma, cada classe é representada por um retângulo, cuja base é o intervalo de classe e cuja altura é a freqüência relativa da classe. Já no polígono de freqüências, o centro de cada classe é representado por um ponto, e os pontos, em seguida, são unidos entre si. A representação gráfica através de polígono de freqüências é mais apropriada para se compararem duas ou mais distribuições, visto que sua construção permite apresentar várias distribuições em um único gráfico. Outra vantagem é que, tanto no histograma como no polígono de freqüências, pode-se facilmente localizar a moda (valor amostral mais freqüente) e a mediana (medida central) - conceitos já definidos neste capítulo.

\section{DistribuiçÃo BINOMIAL}

Quando um experimento tem apenas duas possibilidades excludentes de ocorrência e a probabilidade de cada resultado permanece constante ao longo das suas repetições independentes, ele é chamado de experimento binomial ou teste de Bernoulli. O modelo tradicional para tal experimento é o de uma moeda lançada, e o possível resultado ou é cara, ou é coroa. Para cada repetição do experimento (lançar a moeda), os resultados possíveis serão sempre dois - cara ou coroa - com probabilidades independentes dos resultados obtidos em experimentos anteriores.

As propriedades de um experimento binomial são resumidas assim:

1) deve haver um número definido de repetições;

2) o resultado de cada repetição deve ser um entre dois possíveis eventos; 
3) as probabilidades de cada uma das duas possibilidades devem permanecer constantes ao longo das repetições; 4) e cada repetição deve independer da outra.

Em geral, como apenas dois resultados são possíveis, designa-se a probabilidade de um evento por $\mathbf{p}$ e a do outro por $\mathbf{q}=1$ - p. Como exemplos, têm-se: transmissão de uma doença infecciosa; gravidez resultar em menina ou menino; paciente morrer ou não dentro de um ano; paciente ter teste positivo ou negativo para o HIV, etc.

Suponha-se que se queira investigar a presença de certa doença infecciosa entre três irmãos. Todos os resultados possíveis estão listados na Tabela 6.3, como segue:

TABela 6.3 - Distribuição de doença infecciosa entre três irmãos

\begin{tabular}{ccccc}
\hline Irmão 1 & Irmão 2 & Irmão 3 & Probabilidade & $\begin{array}{c}\text { No de indivíduos } \\
\text { não infectados }\end{array}$ \\
\hline N & N & N & p. p. p & 3 \\
N & N & D & p. p. q & 2 \\
N & D & N & p. q. p & 2 \\
D & N & N & q. p. p & 2 \\
N & D & D & p. q. q & 1 \\
D & N & D & q. p. q & 1 \\
D & D & N & q. q. p & 1 \\
D & D & D & q. q. q & 0 \\
\hline
\end{tabular}

$\mathrm{N}=$ não infectado; $\mathrm{D}=$ doente

Para o cálculo das probabilidades, usa-se o produto das probabilidades dos eventos individuais porque eles são independentes.

Na Tabela 6.3, o irmão 1 é o mais velho; o 2, o do meio; e o 3 , o mais novo. A probabilidade de uma criança não estar infectada é $\mathbf{p}$, e a probabilidade de ela ser doente é $\mathbf{q}=\mathbf{1}-\mathbf{p}$. As probabilidades dadas na tabela foram calculadas segundo a fórmula para a probabilidade conjunta de três eventos independentes:

$$
p(A \text { e } B \text { e } C)=p(A) \cdot p(B) \cdot p(C) \text {. }
$$

A Tabela 6.4, a seguir, apresenta um sumário dos resultados, em que se despreza a ordem das crianças.

TABELA 6.4 - Probabilidade de ocorrência de crianças não infectadas

\begin{tabular}{ccc}
\hline $\begin{array}{c}\mathbf{N}^{\circ} \text { de não } \\
\text { infectados }(\mathrm{K})\end{array}$ & $\begin{array}{c}\mathbf{N}^{\circ} \text { de maneiras em que K } \\
\text { pode ocorrer }\end{array}$ & $\begin{array}{c}\text { Probabilidade de } \\
\text { ocorrer K }\end{array}$ \\
\hline 0 & 1 & $\mathrm{q}^{3}$ \\
1 & 3 & $3 \mathrm{pq}^{2}$ \\
2 & 3 & $3 \mathrm{p}^{2} \mathrm{q}$ \\
3 & 1 & $\mathrm{p}^{3}$ \\
\hline
\end{tabular}

$\mathrm{K}=\mathrm{n}^{\circ}$ de crianças não infectadas 
Como existem três crianças, há quatro possibilidades quanto ao número de não-infectados: nenhuma criança; uma criança; duas crianças e as três crianças estarem não infectadas. Cada possibilidade pode ocorrer um certo número de vezes: nenhum infectado ocorre uma vez (DDD); um infectado pode ocorrer de três maneiras diferentes (DNN, NDN, NND); dois infectados podem ocorrer de três maneiras diferentes (DDN, DND, NDD); e três não infectados só podem ocorrer de uma maneira (NNN). Para se calcularem as probabilidades de ocorrência de um dado número de não infectados, foi usada a regra da soma de probabilidades.

\section{DistRIBUIÇÃO NORMAL}

A distribuição normal (distribuição $\mathrm{N}$ ) é representada pela curva normal ou curva Gaussiana. É bastante empregada porque as distribuições empíricas de muitos fenômenos naturais (por exemplo, pressão arterial, altura, peso, valores de colesterol) são aproximadas pela distribuição normal. Além disso, a equação matemática que origina essa curva permite diversas inferências matemáticas, que, por conseqüência, levam a inferências quanto à população das amostras analisadas.

A curva normal, que vai de um valor infinito negativo a um infinito positivo, é uma curva matemática teórica baseada em dois parâmetros: média e desvio padrão, os quais, ao mesmo tempo, definem tanto a curva normal quanto a população de onde a amostra foi retirada; logo, constituem elementos primordiais nesse tipo de estatística paramétrica, assim denominada por se basear nesses dois parâmetros.

As características mais importantes da distribuição normal podem ser assim resumidas (Figura 6.8):

- distribuição normal é unimodal: apresenta uma moda apenas;

- tem "forma de sino" e é simétrica em torno de sua média $\mu$; a média, a mediana e a moda de uma distribuição normal apresentam valores iguais;

- a média é o centro da curva, e a distribuição dos valores maiores que a média e a dos valores menores que a média são simétricas;

- a área total abaixo da curva da distribuição normal é igual a 1 ou $100 \%$, pois é uma distribuição de probabilidades que pode variar de 0 a 1 [N $(0,1)]$. Isso quer dizer que $50 \%$ das observações estão acima da média e 50\%, abaixo;

- aproximadamente $68 \%$ das observações estão dentro de uma região distante um desvio padrão, para ambos os lados, da média $(\mu \pm 1 \sigma)$; 
- cerca de $95 \%$ das observações situam-se em uma região distante dois desvios padrão da média $(\mu \pm 2 \sigma)$;

- aproximadamente $100 \%$ das observações situam-se dentro de uma região distante da média três desvios padrão $(\mu \pm 3 \sigma)$.

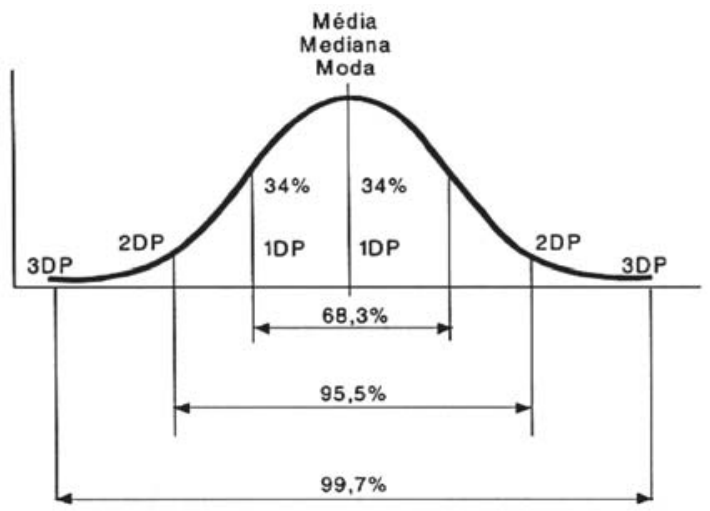

Figura 6.8 - Medidas de tendência central e fração da população incluída entre 1, 2 e 3 desvios padrão (DP)

\section{DISTRIBUIÇÃo Z}

A distribuição $\mathbf{Z}$ baseia-se na curva normal e mede o quanto um determinado resultado afasta-se da média em unidades de desvio padrão. Ambas são curvas normais que representam distribuições de freqüências, podendo ser transformadas em uma curva normal padrão, simplesmente usando o desvio padrão como unidade de medida indicativa dos desvios dos valores da variável em estudo, em relação à média. Para isso, utiliza-se a variável $Z$, que determina a área sob a curva normal padrão.

Quando a variável em estudo tiver distribuição normal, mas média diferente de zero e desvio padrão diferente de um, ainda pode-se usar a tabela para a curva normal padrão. Para tal, é preciso converter os valores $Y$ da distribuição em novos valores $Z$ - chamados de variáveis reduzidas ou desvios relativos:

$$
\mathrm{Z}=\frac{\mathrm{Y}-\mu}{\sigma} \quad \frac{\text { (desvio em relação à média) }}{\text { (desvio padrão) }}
$$

A transformação das variáveis originais $Y$ em variáveis reduzidas $Z$ pode ser visualizada na Figura 6.9: 


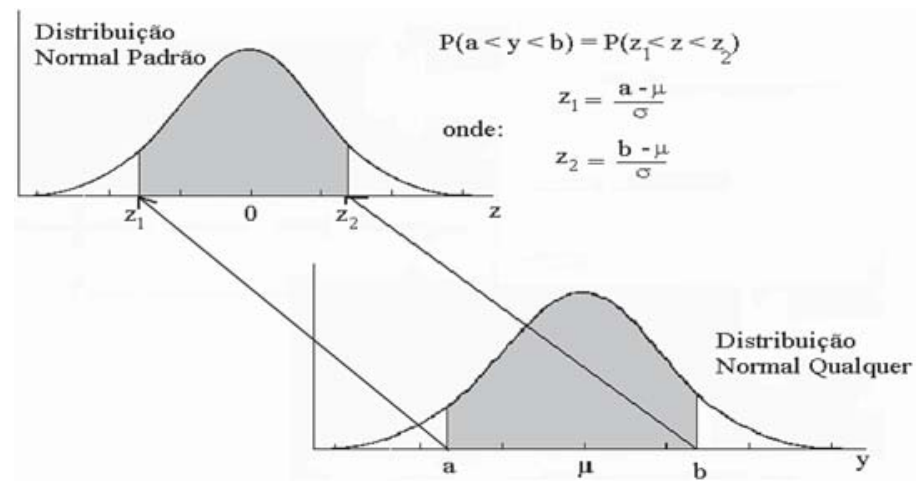

Figura 6.9 - Curvas com distribuição normal e transformação das variáveis originais Y para as variáveis reduzidas $Z$

\section{TESTE DE HIPÓTESES}

Testa-se uma hipótese para se responder à seguinte questão: duas amostras são mesmo diferentes ou pertencem a uma mesma população? Em outras palavras, a hipótese é testada para se determinar, com razoável e conhecida certeza, se as diferenças encontradas entre duas ou mais amostras são verdadeiras ou podem ser explicadas pelo acaso (variabilidade da amostra).

O teste de uma hipótese inclui seis etapas seqüenciais: 1) estabelecer uma hipótese experimental ou alternativa $\left.\left(\mathrm{H}_{1}\right) ; 2\right)$ estabelecer uma hipótese nula $\left(\mathrm{H}_{0}\right)$; 3 ) determinar o tamanho da amostra; 4) colher dados; 5) realizar a análise estatística para determinar a probabilidade de que a hipótese nula seja verdadeira; e 6) rejeitar ou não a hipótese nula.

Considere-se o exemplo da avaliação dos efeitos de um alto nível de iluminação no desempenho de trabalhadores, medido pela quantidade de unidades produzidas em uma linha de montagem. Os trabalhadores foram distribuídos, de forma aleatória, em dois grupos, com 100 elementos cada. O primeiro grupo foi exposto a um alto nível de iluminação, e o segundo grupo, a um nível normal. Os resultados, demonstrados na Tabela 6.5, expressam a média $(\bar{X})$ e o desvio padrão $(\sigma)$ de cada grupo.

TABELA 6.5 - Resultado do teste de variação do desempenho com a iluminação

\begin{tabular}{c|cc}
\hline & $\begin{array}{c}\text { Grupo 1 } \\
\text { Alta iluminação }\end{array}$ & $\begin{array}{c}\text { Grupo 2 } \\
\text { Iluminação normal }\end{array}$ \\
\hline $\bar{X}$ & 24 & 20 \\
$\sigma$ & 6,0 & 6,5 \\
$\mathrm{~N}$ & 100 & 100 \\
\hline
\end{tabular}


Imagina-se, nesse exemplo, a possibilidade de duas populações distintas: aquela em que todos os trabalhadores operam sob alta iluminação (cuja média populacional é $\bar{X}_{1}=24$ ) e aquela em que todos os trabalhadores operam sob iluminação normal (cuja média populacional é $\bar{X}_{2}=20$ ). Deve-se, então, testar se essas duas médias são significativamente diferentes. A forma clássica de escrever as hipóteses possíveis, em termos de hipótese nula $\left(\mathrm{H}_{0}\right)$ e de hipótese experimental ou alternativa $\left(\mathrm{H}_{1}\right)$, é:

$\mathrm{H}_{0}: \mu_{1}-\mu_{2}=0$

$\mathrm{H}_{1}: \mu_{1}-\mu_{2}{ }^{1} 0$

onde:

$\mathrm{H}_{0}=$ diferença entre essas médias $\left(\mu_{1}-\mu_{2}\right)$ é nula, ou seja, essa diferença resulta do puro acaso;

$\mathrm{H}_{1}=\mathrm{a}$ diferença entre essas médias $\left(\mu_{1}-\mu_{2}\right)$ não é nula, ou seja, a diferença encontrada é resultado do fator iluminação, em que a alta iluminação influencia o desempenho (D) dos trabalhadores.

Cabe destacar que aqui se está trabalhando com amostras, portanto as médias apresentadas na tabela são amostrais — representadas por $\bar{X}$. Já a hipótese que se testa refere-se à população em estudo, e as médias são representadas por $\mu$.

Para se usar o conhecimento relativo a uma distribuição $\mathrm{N}$ $(0,1)$, basta que se convertam estas coordenadas $\left\{\left(\sigma_{D X 1}-\sigma_{D X 2}\right), \sigma_{D X}\right\}$ para $\mathrm{N}(0,1)$.

$$
\begin{aligned}
& z=\frac{\bar{X}_{1}-\bar{X}_{2}}{\sigma_{D_{\bar{x}}}}=\frac{\bar{X}_{1}-\bar{X}_{2}}{\sqrt{\sigma_{\bar{x}_{1}}^{2}+\sigma_{\bar{x}_{2}}^{2}}} \\
& z=\frac{24-20}{\sqrt{\left(\frac{6,0}{\sqrt{100}}\right)^{2}+\left(\frac{6,5}{\sqrt{100}}\right)^{2}}}=4,52
\end{aligned}
$$

Rejeitando-se a hipótese nula $\left(\mathrm{H}_{0}\right)$ com $95 \%$ de certeza de que a diferença entre as médias das duas amostras não resultou do acaso, deve-se escolher um ponto de $N(0,1)$ tal que $95 \%$ da área da curva esteja entre $z \mathrm{e}-\mathrm{z}$, ou seja, a área das duas proporções menores é de 0,025 para cada lado. Na Tabela 6.6, vê-se que qualquer valor de $z$ maior do que 1,96 atende a esse critério - o que é o caso. 
Em certas situações, tem-se a certeza de que qualquer variação que se verifique ocorrerá em uma direção. Em outras palavras, no exemplo acima, qualquer que seja a variação por efeito da iluminação, ela contribuirá para aumentar o desempenho dos trabalhadores. Se esse for o caso, pode-se reescrever as hipóteses desta forma:

$$
\begin{aligned}
& \mathrm{H}_{0}: \mu_{1}-\mu_{2} \leq 0 \\
& \mathrm{H}_{1}: \mu_{1}-\mu_{2}>0
\end{aligned}
$$

Assim, se houver influência da iluminação sobre o desempenho, ela vai contribuir para aumentá-lo. Nesse caso, interessa aqui a parte mais à direita da curva normal, o que dá um valor de $z$, para $5 \%$ de possibilidade de erro, igual a 1,64. Com mais razão, portanto, pode-se rejeitar $\mathrm{H}_{0}$ e aceitar $\mathrm{H}_{1}$.

Um esquema resumido do teste de hipóteses está ilustrado na Figura 6.10.

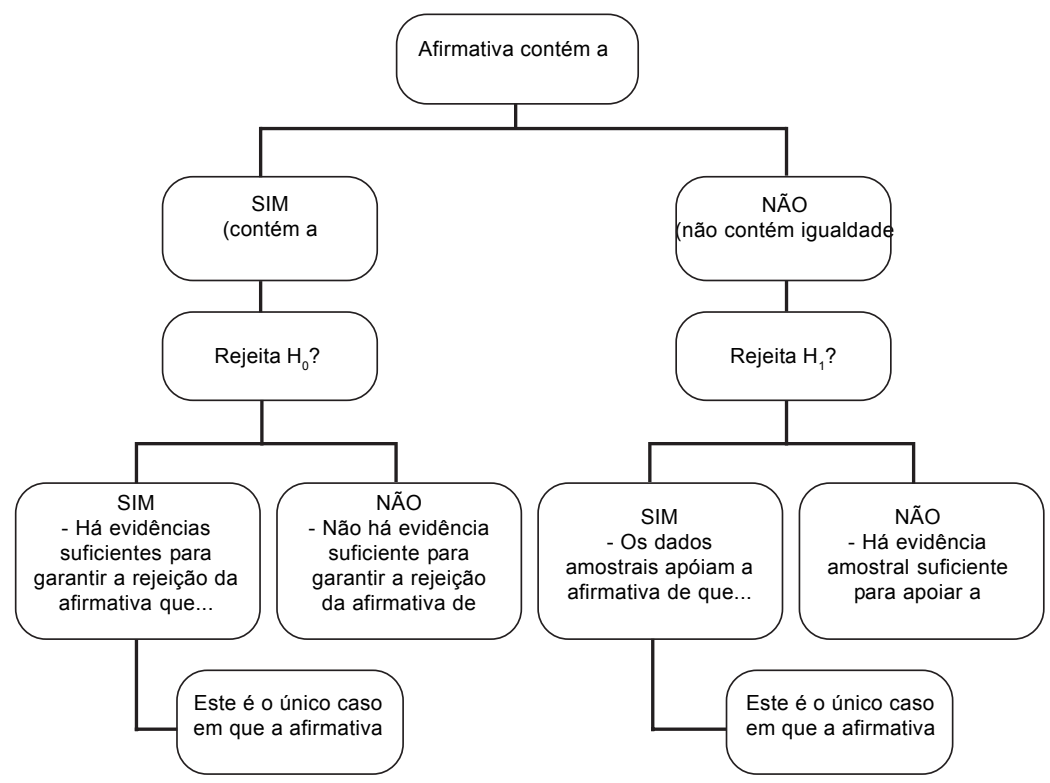

Figura 6.10 - Esquema resumido do teste de hipóteses

Deve-se observar que, ao se fazer uma inferência estatística, é possível haver dois tipos de diferentes de erros, como foi visto no capítulo 5 . Assim, à luz dos testes de hipóteses cometemse: erro tipo 1 ou $\alpha$ - quando se rejeita $\mathrm{H}_{0}$, e esta não deveria ser rejeitada; e, erro tipo 2 ou $\beta$ - quando se aceita $\mathrm{H}_{0}$, e esta não de deveria ser aceita. Quando se espera poder aceitar a hipótese 
alternativa $\mathrm{H}_{1}$, é preciso estar atento para a ocorrência de erros do tipo 1. Em outras palavras, deve haver certeza de que existe uma diferença entre as médias que não resulta do acaso.

Por outro lado, quando se deseja mostrar que as diferenças entre as médias são resultantes do acaso, ou então se prevenir da possibilidade de não se considerar o efeito de uma variável independente, o erro tipo 1 não é tão importante. Isso porque, nesse caso, o que se deseja é um baixo erro tipo 2; logo, deve-se diminuir a exigência em relação ao tipo 1, pois isso é fator de proteção no que se refere ao erro tipo 2. Com efeito, ainda que a relação entre os erros tipo 1 e 2 não seja linear, um cresce enquanto o outro decresce.

O poder de um teste estatístico é definido como a habilidade de rejeitar $\mathrm{H}_{0}$ quando, de fato, ela deveria ser rejeitada (poder $=1$ $\beta)$. Quanto maior for o tamanho da amostra ou o nível de significância utilizado, necessário para validar o resultado, maior será o poder de predição desse teste.

\section{MÉTODOS ESTATÍSTICOS}

As técnicas estatísticas para dados intervalares ou de maior nível são denominadas estatísticas paramétricas, as quais requerem premissas quanto à normalidade da distribuição da variável dependente e à homogeneidade das variâncias. Caso não se possa garantir a normalidade dos dados ou a homogeneidade das variâncias, há outras opções: trata-se dos testes estatísticos não paramétricos. Mas a questão é: que teste usar? A resposta depende basicamente de três fatores: 1) tamanho da amostra; 2) tipo de dados; e 3) informações sobre a distribuição dos dados.

Quando se trabalha com dados intervalares ou numéricos, a decisão depende do tamanho da amostra:

- em amostras com mais de 30 elementos, a distribuição pode ser aproximada para uma normal; senão é mais conveniente utilizar o teste $t$. Quando se têm mais que duas amostras independentes, utiliza-se a análise de variância, em vez do teste $t$;

- em amostras com menos de 30 elementos, se não for possível garantir a normalidade dos dados ou a homogeneidade das variâncias, não se pode utilizar testes paramétricos. Pode-se, então, transformar os dados em ordinais e utilizar testes não paramétricos.

Testes não paramétricos diferem segundo o tipo de dado (nominal ou ordinal) e a característica da amostra (pareada ou independente). Assim, para amostras pareadas (dados do tipo antes/ depois) não se usa o mesmo teste que fornece os resultados para amostras independentes - ainda que o nível de mensuração das variáveis seja o mesmo.

O nível de significância aqui considerado para os testes estatísticos será de: 
$-P<0,05$, diferença estatisticamente significante;

$-P \geq 0,05$, sem diferença estatisticamente significante.

\section{Estatística Z (escore Z)}

Conforme definida neste capítulo, a estatística $Z$ baseia-se na curva normal e mensura o quanto um determinado valor afastase da média em unidades de desvio padrão. Assim, se dada variável em estudo tiver distribuição normal, com média diferente de zero e desvio padrão diferente de um, pode-se utilizar também a tabela para a curva normal padrão.

Por exemplo, considere-se uma população de pessoas adultas para as quais foi medida a altura. A distribuição das alturas é normal com média de 172 centímetros e desvio padrão de 5 centímetros. Nesse sentido, que proporção dessa população tem estaturas menores que 177 centímetros? Aplicando-se a fórmula:

$$
\begin{aligned}
& Z=\frac{Y-\mu}{\sigma} \text { tem-se: } \\
& Z=\frac{177-172}{5}=\frac{5}{5}=1 \quad \text { (variável reduzida) }
\end{aligned}
$$

Na Tabela 6.6 para curva normal padrão, a área entre a média 0 e $Z=1,00$ é 0,3413 . Como se quer a proporção de alturas menores que 177 centímetros, deve-se considerar, também, valores inferiores à média, ou seja, de 172 centímetros ou valores menores. A área de cada lado da média vale $0,5(0,5$ de 0 a +8 e 0,5 de -8 a 0 ). Portanto, a porcentagem de alturas abaixo de 177 centímetros é igual a $0,3413+0,5000=0,8413 \Rightarrow 84,13 \%$. Assim, para responder à pergunta, basta subtrair 0,8413 de 1 , visto que a área total sob a curva normal padrão vale 1 . Logo, tem-se que: $1-0,8413=$ $0,1587 \Rightarrow 15,87 \%$. 
TABELA 6.6 - Áreas de uma distribuição normal padrão

\begin{tabular}{|c|c|c|c|c|c|c|c|c|c|c|}
\hline Z & 00 & 0,01 & 02 &, 03 &, 04 &, 05 &, 06 & 0,07 & 0,08 & 0,09 \\
\hline & & & & & & & & & & \\
\hline 1 & & & & & & & & & & \\
\hline 0,2 & & & 371 & & & & & & & \\
\hline 0,3 & 9 & 7 & & & & & & & & \\
\hline 0,4 & 4 & & & & & & & & & \\
\hline & & & & & & & & & & \\
\hline 0,6 & & & & & & & & & & \\
\hline 0,7 & & & & & & & & & & \\
\hline 0,8 & & & & & & & & & & \\
\hline 0,9 & & & & & & & & & & \\
\hline & & & & & & & & & & \\
\hline & & & & & & & & & & \\
\hline 1,2 & & & & & & & & & & \\
\hline 1,3 & & & & & & & & & & \\
\hline 1,4 & & & & & & & & & & \\
\hline $\boldsymbol{L}$ & & & & & & & & & & \\
\hline 1,6 & & & & & & & & & & \\
\hline 1,7 & & & & & & & & & & \\
\hline 1,8 & & & & & & & & & & \\
\hline 1,9 & 0,4 & 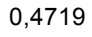 & 26 & & & & & & & \\
\hline 2,0 & & & & & & & & & & \\
\hline 2,1 & & & & & & & & & & \\
\hline 2,2 & & & & & & & & & & \\
\hline 2,3 & & & & & & & & & & \\
\hline 2,4 & 04 & 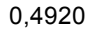 & 2 & 0 & 0 & 9 & 31 & 0 & & 36 \\
\hline 2,5 & & & & & & & & & & \\
\hline 2,6 & & & & & & & & & & \\
\hline 2,7 & & & & & & & & 0,4972 & & 4974 \\
\hline 2,8 & 19. & 1075 & 4976 & 0,4977 & 0,4977 & 0,4978 & 0,4979 & 0,4979 & & \\
\hline 2,9 & & & & & & & & & & \\
\hline & 0,4987 & 0,4987 & 0,4987 & 0,4988 & 0,4988 & 0,4989 & 0,4989 & 0,4989 & 0,4990 & 0,4 \\
\hline
\end{tabular}

\section{Teste $T$ de Student}

Este teste só é aplicado a dados do tipo contínuo e com distribuição Gaussiana. É, provavelmente, o mais usado para comparar duas amostras, podendo ser também, aplicado a uma única amostra. Assim, o teste $t$ pode ser empregado para verificar se uma única amostra provém ou não de uma população cuja média é conhecida, comparando a média da mesma com uma média hipotética teórica, extraída da literatura ou de outro experimento de população.

No caso de comparação entre as médias $\bar{X}_{1}$ e $\bar{X}_{2}$ de duas amostras, tem-se :

$$
\begin{array}{lll}
H_{0}: \mu_{1}-\mu_{2}=0 & \text { ou } & H_{0}: \mu_{1}=\mu_{2} \\
H_{1}: \mu_{1}-\mu_{2} \neq 0 & \text { ou } & H_{1}: \mu_{1} \neq \mu_{2}
\end{array}
$$


É preciso avaliar com cuidado se a escolha e a aceitação dos resultados de um teste estatístico são as mais apropriadas. No caso do teste $t$ de Student para duas amostras independentes (não pareadas), as seguintes questões devem ser avaliadas: os dados amostrais são de populações com distribuição normal?; as duas populações têm a mesma variância?; os dados são não pareados?; os erros são independentes?; a comparação dever ser exatamente entre dois grupos?; deseja-se, de fato, comparar médias?

$\mathrm{O}$ teste $t$ de Student para duas amostras independentes incorpora informações relativas à variabilidade das médias das duas amostras. A Tabela 6.7 demonstra um exemplo de aplicação do teste $t$ para duas amostras independentes.

TABela 6.7 - Fatores de risco para infecções por Staphylococcus aureus resistentes (MRSA) ou sensíveis (MSSA) à meticilina em pacientes internados no Hospital de Clínicas da Universidade Federal de Uberlândia (HC-UFU)

\begin{tabular}{cccc}
\hline FATORES DE RISCO & $\begin{array}{c}\text { MRSA (\%) } \\
\mathbf{n = 4 5}\end{array}$ & $\begin{array}{c}\text { MSSA (\%) } \\
\mathbf{n = 5 7}\end{array}$ & $\begin{array}{c}\text { Valor } \\
\boldsymbol{P} *\end{array}$ \\
\hline Idade $(\bar{X} \pm \mathbf{s})$ & $41,2 \pm 24,3$ & $25,7 \pm 22,9$ & $<0,01$ \\
Tempo de internação total $(\bar{X} \pm \mathrm{s})$ & $45,5 \pm 25,2$ & $27,8 \pm 24,2$ & $<0,01$ \\
Internação prévia à infeç̧ão $(\bar{X} \pm \mathrm{s})$ & $24,9 \pm 20,4$ & $12,6 \pm 16,3$ & $<0,01$ \\
\hline
\end{tabular}

$\overline{\mathrm{X}}=$ média, $\mathrm{s}=$ desvio-padrão; ${ }^{*} P<0,05=$ diferenças estatisticamente significantes.

O teste $t$ de Student pareado ou para duas amostras dependentes será empregado quando:

- se quer avaliar medidas de uma variável (por exemplo, peso) antes e após intervenção no mesmo indivíduo;

- se recrutam indivíduos aos pares combinando (pareando) variáveis como idade, sexo, grupo étnico ou severidade da doença em questão, etc;

- se realiza um experimento laboratorial várias vezes com amostras controles e experimentais em paralelo;

- se deseja medir uma variável entre gêmeos ou filhos e pais. No caso de duas amostras dependentes (pareadas), as seguintes questões devem ser avaliadas: deseja-se realmente comparar médias?; deseja-se comparar exatamente dois grupos?; os dados das populações analisadas são pareados?; os pares de dados são independentes?

Um exemplo da aplicação do teste $t$ para duas amostras dependentes pode ser observado na Tabela 6.8, onde se comparam as médias da pressão arterial antes e após tratamento. 
TABELA 6.8 - Comparação entre as médias da pressão arterial de dez pacientes submetidos a determinado tratamento

\begin{tabular}{cccc}
\hline Pressão arterial & $\begin{array}{c}\text { Antes do tratamento } \\
\mathbf{n}=\mathbf{1 0}\end{array}$ & $\begin{array}{c}\text { Após tratamento } \\
\mathbf{n}=\mathbf{1 0}\end{array}$ & $\begin{array}{c}\text { Valor } \\
\boldsymbol{P}^{*}\end{array}$ \\
\hline Média $(\overline{\mathrm{x}})$ & 143,3 & 119,6 & \\
Desvio padrão $(\boldsymbol{\sigma})$ & 14,73 & 8,36 & $<0,01$ \\
\hline${ }^{*} p<0,05=$ diferenças estatisticamente significantes & &
\end{tabular}

\section{INTERVALO DE CONFIANÇA}

O intervalo de confiança é outra maneira de se calcular uma estimativa de um parâmetro desconhecido. Os bioestaticistas desenvolveram métodos para cálculo de intervalos de confiança para grande parte dos testes estatísticos, e o raciocínio para sua compreensão é sempre o mesmo. No caso da média, o intervalo de confiança quantifica a sua precisão. Dessa forma, os valores dentro do intervalo de confiança - por exemplo, de $95 \%$ - dão $95 \%$ de certeza de que o intervalo compreendido contém a verdadeira média da população.

O intervalo de confiança se estende em cada direção por uma distância igual ao erro padrão da média multiplicado por uma constante ( $t$ crítico), originária da tabela de distribuição do $t$ de Student. Essa constante depende do grau de confiança que se deseja e do número de graus de liberdade do experimento em questão $(\mathrm{N}-1)$. O intervalo de confiança para um parâmetro desconhecido como uma probabilidade de $1-\alpha$, pode ser igual a $99 \%, 95 \%, 90 \%$, $85 \%$, etc. Dessa maneira, a será o nível de significância, isto é, o erro que está se cometendo ao afirmar que, por exemplo, em $95 \%$ das vezes o intervalo $\mathrm{q} 1<\mathrm{q}<\mathrm{q} 2$ contém $\mathrm{q}$.

Os valores do intervalo de confiança da média podem ser obtidos através da fórmula:

$$
\overline{\mathrm{x}} \pm\left(\mathrm{t}_{\mathrm{c}} \times \sigma_{\mathrm{x}}\right) \quad \text { ou } \quad \overline{\mathrm{x}}-\left(\mathrm{t}_{\mathrm{c}} \times \sigma_{\mathrm{x}}\right) \leq \boldsymbol{\mu} \leq \overline{\mathrm{x}}+\left(\mathrm{t}_{\mathrm{c}} \times \sigma_{\mathrm{x}}\right)
$$

onde:

$\overline{\mathrm{X}}=$ média amostral

$\sigma_{\mathrm{x}}=$ erro padrão da média

$\mathrm{t}_{\mathrm{c}}=t$ crítico fornecido pela tabela de distribuição $t$ de Student

$\mu=$ média populacional

O intervalo de confiança para a média populacional $\mu$ com base em grandes amostras $(n>30)$ é calculado como se segue:

$$
\overline{\mathrm{x}}-\mathrm{Z} \frac{\alpha}{2} \times \frac{\sigma}{\sqrt{n}}<\mu<\overline{\mathrm{x}}+\mathrm{Z} \frac{\alpha}{2} \times \frac{\sigma}{\sqrt{n}}
$$


Considere-se o exemplo de uma população de 100 indivíduos cuja temperatura corporal média amostral foi $\overline{\mathrm{X}}=36,75^{\circ} \mathrm{C}$ e erro padrão da média $\sigma=0,62$. Para um grau de confiança de $95 \%$, o cálculo do intervalo de confiança será:

$$
\begin{aligned}
\overline{\mathrm{x}}-\mathrm{Z}_{\frac{\alpha}{2}} \times \frac{\sigma}{\sqrt{n}}<\mu & <\overline{\mathrm{x}}+\mathrm{Z}_{\frac{\alpha}{2}} \times \frac{\sigma}{\sqrt{n}} \\
36,75-1,96 \times \frac{0,62}{\sqrt{100}} & <\mu<36,75+1,96 \times \frac{0,62}{\sqrt{100}} \\
36,75-0,1215 & <\mu<36,75+0,1215 \\
36,63 & <\mu<36,87
\end{aligned}
$$

Este resultado pode ser expresso também como $\mu=36,75 \pm 0,1215$.

É muito comum se aplicar o intervalo de confiança em casos de proporção ou probabilidade $(n>30)$, cuja fórmula para cálculo é a seguinte:

$$
f-Z_{\frac{\alpha}{2}} \sqrt{f(1-f) / n} \leq p \leq f+Z \frac{\alpha}{2} \sqrt{f(1-f) / n}=1-\alpha
$$

Por exemplo, em uma população de 78 pessoas estudadas para se detectar a presença de determinado parasito, 58 mostraramse parasitadas.

Assim, como ficará o intervalo de confiança ao nível de $95 \%$ para a subpopulação parasitada? Aplicando-se a fórmula no exemplo acima $(n=78 ; x=58)$ :

$f=x / n=58 / 78=0,744 \rightarrow 1-f=0,256$

$Z=1,96$ para $95 \%$ de confiança (esse valor não muda nos outros cálculos)

$$
\begin{gathered}
f-Z_{\frac{\alpha}{2}} \sqrt{f(1-f) / n} \leq p \leq f+Z \frac{\alpha}{2} \sqrt{f(1-f) / n}=1-\alpha \\
0,744-0,097 \leq p \leq 0,0,744+0,097 \\
0,647 \leq p \leq 0,841
\end{gathered}
$$

Portanto, o intervalo de confiança tem:

limite inferior $=64,7 \%$ e

limite superior $=84,1 \%$.

Vale lembrar que, quanto maior for a amostra, mais estreito será o intervalo de confiança. Para calcular intervalos com $99 \%$ de confiança, o $Z \frac{\alpha}{2}$ é 2,575; para $90 \%$ de confiança, o $Z \frac{\alpha}{2}$ é 1,645 . 


\section{ANÁLISE de VARIÂNCIA (ANOVA)}

A análise de variância, ou ANOVA, também é um teste paramétrico de grande poder estatístico; porém é utilizada na comparação de três ou mais amostras ou tratamentos. Por ser paramétrica, exige variáveis com distribuição normal, amostras independentes tomadas aleatoriamente e variâncias semelhantes das amostras.

A ANOVA compara a dispersão dos dados nos grupos ou tratamentos estudados. Seguindo o raciocínio de que as variâncias devem ser iguais entre grupos analisados, então a dispersão dos dados também o será. Em suma, ela compara a relação da dispersão dos dados entre os grupos com a dispersão dentro dos grupos. Assim, pelos dados coletados, são feitos os seguintes cálculos:

1) as somas dos quadrados dos desvios (SQD):

a) SQD da população ou SQD total $\left(S Q D_{T}\right)$;

b) SQD dentro das amostras ou SQD dentro $\left(S D_{D}\right)$;

c) SQD entre as amostras ou SQD entre $\left(\mathrm{SQD}_{\mathrm{E}}\right)$;

2) determinação dos quadrados médios:

a) quadrado médio dentro das amostras (QMDD);

b) quadrado médio entre as amostras $\left(\mathrm{QMD}_{\mathrm{E}}\right)$;

3) cálculo da estatística $F$ onde: $F_{\text {calculado }}=\left(Q M D_{E} / Q M D_{D}\right)$.

Teste de hipóteses

$\mathrm{H}_{0}$ : não há diferença entre as médias das amostras (tratamentos) ou todas as amostras são iguais.

$\mathrm{H}_{1}$ : pelo menos uma amostra tem média diferente.

De acordo com o nível de significância desejado (a) e o grau de liberdade em questão, procura-se na tabela de distribuição de $\mathrm{F}$ o valor de $\mathrm{F}_{\text {critico }}$ :

$$
\text { Se } F_{\text {calculado }} \geq F_{\text {crítico }} \Rightarrow \text { rejeita-se } H_{0}
$$

Há muitas informações sobre a ANOVA, inclusive acerca de sua utilização no caso de dados pareados e em pós-testes. Programas computacionais estatísticos disponibilizam, de forma simples, esses cálculos. Entretanto, livros mais específicos devem ser consultados para se fundamentarem os princípios básicos da ANOVA e se compreenderem suas fórmulas. 
Teste do sinal (sign test) e de McNemar

Em geral, o teste do sinal (sign test) é empregado para determinar se, entre pares de observações, há diferenças sistemáticas que se possam traduzir por um sinal + (resultado da segunda observação maior que o da primeira), um sinal - (resultado da segunda observação menor que o da primeira) ou 0 (quando não há diferença entre as observações). Por usar sinais em vez de medidas quantitativas, este teste recebeu tal nome. Ele também pode ser usado para a comparação de duas amostras pareadas de dados ordinais; mas, quando se eliminam os valores "0", torna-se praticamente útil e simples de ser usado para dados nominais. Nessa abordagem, o teste do sinal é conhecido, também, como teste de McNemar - a Tabela 6.9 demonstra um exemplo típico de aplicação desse teste.

TABela 6.9 - Uso de cinto de segurança antes e após envolvimento em acidentes de carro

\begin{tabular}{lcccc}
\hline & \multicolumn{4}{c}{ Uso regular após acidente } \\
\cline { 2 - 5 } Uso regular antes do acidente & & Sim & Não & Total \\
& Sim & 60 & 6 & 66 \\
& Não & 19 & 15 & 34 \\
& TOTAL & 79 & 21 & 100 \\
\hline
\end{tabular}

Valor de $p=0,0003$

Com um valor de $P<0,05$ (nível de significância de 95\%), pode-se concluir que, após o acidente, houve aumento significativo no uso de cinto de segurança.

\section{Teste U de Mann-Whitney}

O teste $U$ de Mann-Whitney pode ser usado para comprovar se dois grupos independentes apresentam diferenças ou não, ou se foram ou não extraídos da mesma amostra; mas, para isso, é preciso que se chegue a um grau de mensuração, pelo menos em escala ordinal (ranqueamento). Esse teste é uma das mais poderosas - ou sensíveis - provas não paramétricas e constitui alternativa de grande utilidade à prova paramétrica $t$ para amostras independentes; aliás, em certas situações, ele oferece maior poder de rejeitar a hipótese nula que o teste $t$.

$\mathrm{A}$ interpretação do teste $\mathrm{U}$ é idêntica à do teste $t$, exceto que, para se aplicar o primeiro, combinam-se as observações ou os escores de ambos os grupos, relacionando-os por ordem ascendente, e nesta consideram-se os valores algébricos; dito de outro modo, os postos mais baixos são atribuídos aos maiores números negativos (caso haja). 
Antes de escolher esse teste, devem ser avaliadas as seguintes questões: os erros são independentes?; os dados são não pareados?; deseja-se comparar exatamente dois grupos?; desejase, de fato, comparar medianas?; os dados amostrados são de populações com distribuição não Gaussiana?

A Tabela 6.10 descreve um exemplo de aplicação desse teste; com base nos resultados descritos nesse estudo, e $P<0,003$, conclui-se que as sociedades com explanações orais de enfermidades são superiores em ansiedade de socialização oral às sociedades sem explanação oral.

TABELA 6.10 - Ansiedade de socialização oral e explanação oral de enfermidades

\begin{tabular}{cccc}
\hline $\begin{array}{c}\text { Sociedades sem } \\
\text { explanação oral }\end{array}$ & $\begin{array}{c}\text { Grau de ansiedade } \\
\text { de socialização oral }\end{array}$ & $\begin{array}{c}\text { Sociedades com } \\
\text { explanação oral }\end{array}$ & $\begin{array}{c}\text { Grau de ansiedade de } \\
\text { socialização oral }\end{array}$ \\
\hline A & 13 & $\mathrm{I}$ & 17 \\
B & 12 & II & 16 \\
C & 10 & III & 15 \\
D & 10 & IV & 15 \\
E & 10 & V & 15 \\
F & 10 & VI & 14 \\
G & 9 & VIII & 14 \\
H & 8 & VIII & 14 \\
I & 8 & IX & 13 \\
J & 7 & $X$ & 13 \\
K & 7 & XI & 13 \\
L & 7 & XIIII & 12 \\
M & 7 & XIV & 12 \\
N & 7 & $X V$ & 12 \\
O & 6 & XVI & 12 \\
& & $X V I I$ & 11 \\
& & $X V I I I$ & 10 \\
& & $X I X$ & 10 \\
& & $X X$ & 10 \\
& & $X X I$ & 8 \\
& & $X X I I$ & 6 \\
\hline
\end{tabular}

$p<0,003$

\section{INTERDEPENDÊNCIA ENTRE DUAS VARIÁVEIS}

Em diversos estudos da área biomédica, é comum o interesse pela avaliação da relação entre duas variáveis - as quais podem ser qualitativas (nominais ou ordinais) ou quantitativas (discretas ou contínuas). Em geral, as freqüências de ambas as variáveis são apresentadas em forma de tabelas de associação $(2 \times 2=$ duas colunas $x$ duas linhas), com base em diferentes métodos de análise para cada tipo de variável. Assim, análises de associação são quase sempre usadas para o caso de variáveis qualitativas, e análises de correlação e regressão, para variáveis quantitativas. 
INTERDEPENDÊNCIA DE DUAS VARIÁVEIS QUALITATIVAS

Para se constatar a interdependência de duas variáveis qualitativas, pode-se usar: 1 ) o teste qui-quadrado $\left(\chi^{2}\right)$; ou 2 ) o coeficiente ou índice de associação de Yule $(Q)$.

\section{Teste do QUi-Quadrado $\left(\chi^{2}\right)$}

Trata-se de um teste estatístico não paramétrico poderoso, empregado para diferentes finalidades, como: determinar se duas ou mais variáveis se relacionam e se uma distribuição de freqüência observada difere de alguma distribuição teórica. Por ser não paramétrico, não exige comportamento Gaussiano das variáveis; entretanto, é menos poderoso que os paramétricos. Quando duas variáveis $(A$ e $B)$ são qualitativas, o qui-quadrado pode ser utilizado para se testar a hipótese nula $\left(\mathrm{H}_{0}\right)$, ou seja, para se saber se as distribuições das variáveis são interdependentes. Por exemplo, a ingestão de carne (variável A) não se associa com a presença de enterite necrosante (variável $B$ ).

$\mathrm{Na}$ avaliação da relação entre variáveis, empregam-se tabelas de contingências, onde classicamente dois grupos são comparados; embora um número maior de grupos possa ser, também, comparado. Vale dizer que o termo contingência em estatística é usado conforme seu significado na língua inglesa: qualidade ou estado próprio de uma íntima relação.

A Tabela 6.11 mostra a distribuição de duas variáveis (A e B) e a fórmula para calcular o valor do $\chi^{2}$ a fim de se verificar uma associação entre ambas.

TABeLA 6.11 - Cálculo do valor do $\chi^{2}$

\begin{tabular}{cccc}
\hline & \multicolumn{2}{c}{ Variável A } & Total \\
\cline { 2 - 3 } Variável B & Presente & Ausente & \\
Presente & $a$ & $b$ & $a+b$ \\
Ausente & $c$ & $d$ & $c+d$ \\
Total & $a+c$ & $b+d$ & $N$ \\
\hline
\end{tabular}

$$
\chi^{2}=\frac{[(a d-b c)-n / 2]^{2} n}{(a+b)(a+c)(c+d)(b+d)}
$$

Para um nível de significância de 0,05 , o valor do $\chi^{2}$ crítico para uma tabela $2 \times 2$ é, por exemplo, 3,84 (encontrado em tabelas de $\chi^{2}$ em livros de estatística elementar ou programas computacionais). Se o valor do $\chi^{2}$ calculado for maior que o valor do $\chi^{2}$ 
crítico $(3,84)$, a hipótese nula $\left(\mathrm{H}_{0}\right)$ deve ser rejeitada, a um nível de significância de $5 \%$. Portanto, a hipótese alternativa $\left(\mathrm{H}_{1}\right)$ é aceita, mostrando a associação entre ingestão de carne e enterite necrosante.

Uma tabela de contingência pode também ser exemplificada segundo os dados demonstrados na Tabela 6.12, em que os pacientes com cateteres inseridos na veia jugular apresentavam maior tempo de cateterização do que os pacientes com cateteres na subclávia.

TABELA 6.12 - Tempo de cateterização associado à inserção vascular central em veia jugular ou subclávia de pacientes internados no HC-UFU

\begin{tabular}{ccccc}
\hline & & \multicolumn{2}{c}{ Sítio de Inserção } & \\
\cline { 3 - 4 } & & $\begin{array}{c}\text { Jugular } \\
\mathbf{n}(\%)\end{array}$ & $\begin{array}{c}\text { Subclávia } \\
\mathbf{n}(\%)\end{array}$ & $\boldsymbol{p}$ \\
\cline { 2 - 4 } Tempo de cateterização & $<7$ dias & $10(27,8)$ & $55(56,3)$ & \\
& $\geq 7$ dias & $26(72,2)$ & $35(43,7)$ & 0,01 \\
Total & & $36(100)$ & $80(100)$ & \\
\hline
\end{tabular}

De acordo com o resultado obtido $(P=0,01)$, calculado pelo qui-quadrado, pode-se notar que os pacientes que tenham um cateter inserido em veia jugular, em vez da subclávia, apresentam chance significativa de permanecerem cateterizados por mais de sete dias. Deve-se ressaltar que, se uma das células da tabela de contingência for menor que cinco, é recomendado o uso do teste exato de Fisher em lugar do $\chi^{2}$.

\section{Coeficiente ou índice de associação de Yule (Q)}

Chamado de $Q$ em homenagem a Quételet (1796-1874), feita por Yule (1912), o coeficiente ou índice de associação de Yule $(Q)$ pode medir o grau de associação entre duas variáveis qualitativas com base em uma tabela $2 \times 2-$ como visto na Tabela 6.6. Para o cálculo, usa-se a seguinte fórmula:

$$
Q=\frac{a d-b c}{a d+b c}
$$

O desvio padrão $\left(\mathrm{s}_{\mathrm{Q}}\right)$ de $Q$ é obtido por:

$$
S_{Q}=\frac{1-Q^{2}}{2} \sqrt{\frac{1}{a}+\frac{1}{b}+\frac{1}{c}+\frac{1}{d}}
$$


O intervalo de confiança de $95 \%$ de $Q$ é calculado por: $Q \pm t_{Q}$ $\mathrm{O}$ coeficiente de Yule varia de $-1,0$ a $+1,0$, como no esquema a seguir:

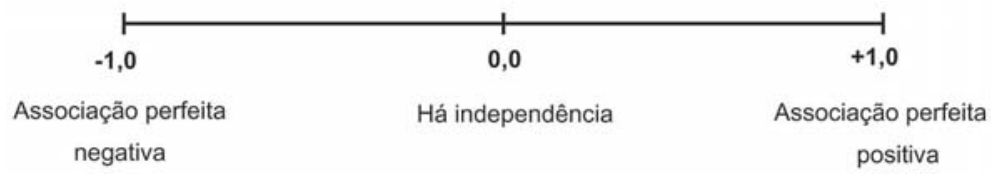

INTERDEPENDÊNCIA DE DUAS VARIÁVEIS QUANTITATIVAS

Para verificar se duas variáveis quantitativas são interdependentes, pode-se utilizar testes de correlação e análises de regressão.

Quando se consideram duas variáveis aleatórias ao mesmo tempo ( $\mathrm{X}$ e $\mathrm{Y})$, as técnicas estatísticas aplicadas são as de regressão e correlação. Embora haja relação entre elas, são usadas para diferentes propósitos. O objetivo mais comum da análise de regressão é obter uma equação que possa ser usada para se prever ou estimar o valor de uma variável em função de um dado valor de outra variável.

A análise de correlação, por outro lado, é usada para se obter uma medida do grau ou da força de associação entre duas variáveis. Tanto para a regressão como para a correlação, os dados consistem de pares de medidas selecionadas da população de interesse.

\section{Correlação}

Se, quando duas séries de observações são analisadas, as variações em uma série correspondem às da outra, diz-se que há correlação entre as variáveis, uma vez que esta mostra a existência de relação funcional entre uma variável e as demais. Tal correlação pode ser positiva (duas variáveis aumentam ou diminuem em paralelo) ou negativa (uma variável aumenta, e outra diminui proporcionalmente), conforme mostra a Figura 6.11. Um exemplo de correlação positiva é encontrado entre altura (variável A) e idade (variável B) de crianças, pois ambas aumentam, em média, paralelamente. Outro exemplo de correlação positiva se encontra entre ingestão de carboidratos (variável A) e peso (variável B), já que ambas variam, em média, em paralelo. Por outro lado, há correlação negativa entre idade de adultos (variável A) e sua velocidade para uma corrida de 100 metros (variável $B$ ), pois a variável $B$ diminui à proporção que a variável $A$ aumenta. 


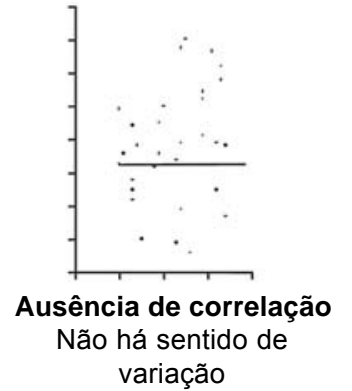

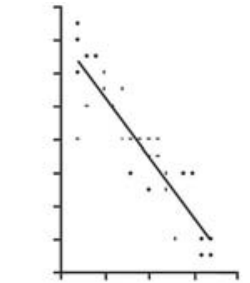

Correlação negativa

As variáveis variam em sentidos opostos

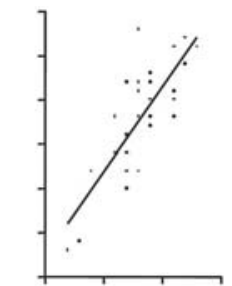

Correlação positiva

As variáveis variam no mesmo sentido

FiguRA 6.11 - Tipos de correlação com representação da reta de regressão linear

Em ciências biomédicas, uma correlação perfeita entre amostras é rara, em virtude de variações entre fontes de observações, organismos vivos e seus produtos, bem como entre diferentes tempos de amostragem. Assim, a relação entre variáveis deve ser sempre considerada "em média".

O grau de correlação entre dois conjuntos de observações compreende dois fatores: 1) parte da relação consiste em uma verdadeira correlação; 2) parte da relação consiste em uma variação aleatória devido a várias causas indeterminadas.

Quando duas séries de observações são analisadas para se constatar a existência de uma relação entre as variáveis, o primeiro passo é a construção de um gráfico de dispersão x por y (scatter graph), em que o eixo vertical (y) representa, em geral, os valores da variável dependente (resultados experimentais) e o eixo horizontal $(x)$ representa os valores da variável independente (escala de tempo, altura ou outra classificação observada).

Entretanto, nem sempre se pode identificar com clareza as variáveis "dependentes" e "independentes". Por exemplo, é razoável estabelecer que, em média, a altura das crianças é dependente da idade, e não o inverso. Em outras situações em que uma variável não parece ser dependente da outra variável, qualquer eixo do gráfico pode ser utilizado para representar uma ou outra variável. Mas as observações a partir das quais as inferências são feitas, em geral, são representadas na linha basal (eixo x).

O grau de correlação é medido pelo coeficiente de correlação $(r)$, em uma escala de valores de $-1,0-0-+1,0$, em que o valor zero indica a completa ausência de correlação, e os valores $+1,0$ e $-1,0$ indicam perfeita correlação positiva e negativa, respectivamente.

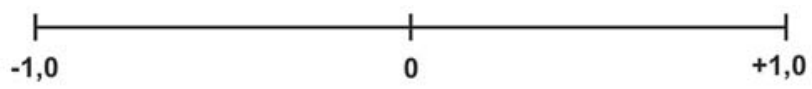

Perfeita correlação negativa
Ausência de correlação
Perfeita correlação positiva 
Um exemplo de correlação positiva pode ser visualizado na Figura 6.12, onde se mostra que anticorpos anti-lgM humana se correlacionam positivamente com anticorpos anti-IgM canina, utilizados como anticorpos de captura em um ELISA-IgM para toxoplasmose canina. Cada ponto representa uma amostra de soro com os valores correspondentes de títulos de anticorpos IgM antiToxoplasma gondii, quando foi utilizado anti-lgM humana (eixo $\mathrm{x}$ ) ou anti-IgM canina (eixo y) como anticorpos de captura.

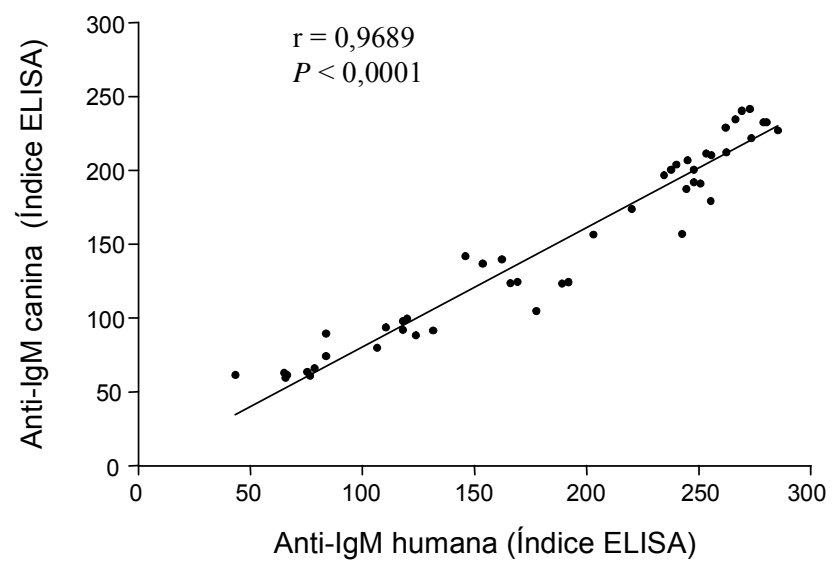

FIgURA 6.12 - Correlação entre anti-lgM humana e anti-IgM canina utilizadas como anticorpos de captura em ELISA-IgM em amostras de soros de cães experimentalmente infectados com Toxoplasma gondii.

Fonte: Adaptado de Silva et al. (2002).

O coeficiente de correlação de Pearson ( $r$ ) mede o grau de relação linear entre duas variáveis. Se há uma perfeita correlação linear entre elas, significa que todos os valores observados estão em uma linha reta, e $r=+1,0$ ou $r=-1,0$.

A fórmula do coeficiente de correlação de Pearson para variáveis $\mathrm{x}$ e y é:

$$
r=\frac{\sum\left(x_{i}-\bar{x}\right)\left(y_{i}-\bar{y}\right)}{\sqrt{\sum\left(x_{i}-\bar{x}\right)^{2} \sum\left(y_{i}-\bar{y}\right)^{2}}}
$$

onde:

$x_{i} / y_{i}=$ observações individuais (1 até $n$ )

$\bar{x} / \bar{y}=$ média das observações $x$ e $y$, respectivamente.

Nesse exemplo, o coeficiente de 0,9689 indica forte correlação positiva entre anticorpos anti-IgM humana e anti-lgM canina utilizados em ELISA-IgM de captura para toxoplasmose canina.

Como já se destacou, uma parte da variação em uma das variáveis $(A)$ resulta de sua relação com a outra variável $(B)$, e a 
outra, de causas indeterminadas (aleatórias). A parte da variação resultante da dependência de uma variável sobre a outra é medida pela variância $\left(r^{2}\right)$. No exemplo referido, $r^{2}=0,9388$ significa que $93,88 \%$ da variação em y é resultado da variação em $x$. Para se testar a significância do coeficiente de correlação ou o desvio de $r$ de 0 (ausência de correlação), estabelecem-se as hipóteses:

$$
\begin{array}{ll}
\mathrm{H}_{0} \text { (hipótese nula): não há correlação entre as variáveis x e y } & \mathbf{H}_{0}: \mathbf{r}=\mathbf{0} \\
\mathrm{H}_{1} \text { (hipótese alternativa): há correlação entre as variáveis x e y } & \mathbf{H}_{1}: \mathbf{r} \neq \mathbf{0}
\end{array}
$$

Com base na formulação dessas hipóteses, utiliza-se o teste $t$ com a seguinte fórmula:

$$
t=r \sqrt{(n-2) /\left(1-r^{2}\right)}
$$

$O$ valor $t$ encontrado é verificado em tabelas $t$ (disponíveis em livros de estatística elementar) ou programas computacionais, em que se encontra o valor de $P$. Assim, o coeficiente de correlação pode ser ou não considerado significante. No exemplo citado (Figura 6.11), o valor de $P<0,0001$ indica correlação positiva altamente significativa entre anticorpos anti-IgM humana e anti-IgM canina; em outras palavras, demonstra que anticorpos anti-lgM humana podem ser usados como anticorpos de captura em ELISA para detecção de lgM canina no sorodiagnóstico da toxoplasmose canina.

O coeficiente de correlação pode ser usualmente calculado por dois testes: 1) o de correlação de Pearson (r) para amostras que apresentam distribuição normal ou Gaussiana e 2) o de correlação de Spearman $\left(r_{s}\right)$ para amostras que não apresentam distribuição normal. Opcionalmente, nesse último caso, as amostras podem ser transformadas em base logarítmica (conformação dos dados a uma distribuição normal) e o teste de correlação de Pearson pode ser aplicado. É importante salientar que o coeficiente de correlação de Pearson visa mensurar só o grau de relação linear e que duas variáveis podem estar altamente relacionadas de modo não linear e, assim, apresentar coeficiente de correlação muito baixo. Além disso, vale ressaltar ainda que correlação não é causa: pode ou não haver conexão causal entre as duas variáveis correlacionadas - como será discutido no Capítulo 7 sobre causalidade do presente livro.

\section{Correlação de rank}

Quando as relações entre variáveis são difíceis ou impossíveis de serem quantificadas com exatidão (variáveis qualitativas ordinais), é possível distribuir os dados em classes ou graduação e, assim, comparar as variáveis nas diferentes categorias. 
Dois coeficientes de correlação usados com freqüência para dados ranqueados são o coeficiente de correlação de Spearman $\left(r_{s}\right)$ e o coeficiente de correlação de Kendall (ô). Como outros métodos não paramétricos, eles não requerem a conformação dos dados a uma distribuição normal.

A título de exemplificação, níveis de anticorpos séricos lgG anti-H. pylori foram comparados entre grupos de pacientes com gastrite apresentando quatro características histológicas da mucosa antral: 1) presença de neutrófilos; 2) presença de células mononucleares; 3 ) atrofia e 4) densidade de H. pylori. Cada uma dessas características - categorias ou variáveis qualitativas ordinais - foi graduada em níveis ou escores, a saber: 0 (normal), 1 (leve), 2 (moderada) e 3 (grave).

Assim, é possível estabelecer uma relação entre as variáveis - ou seja, uma correlação entre os níveis de anticorpos e o grau de gastrite na mucosa antral -, por meio do coeficiente de correlação de rank de Spearman $\left(r_{s}\right)$, cujos coeficientes calculados para os quatro grupos demonstrados na Figura 6.13 foram:

$r_{s}=0,586$ e $P<0,001$ para infiltração de neutrófilos na mucosa antral; $r_{s}=0,620$ e $P<0,001$ para infiltração de células mononucleares na mucosa antral; $r_{s}=0,429$ e $P<0,001$ para atrofia da mucosa antral;

$r_{s}=0,630$ e $P<0.001$ para densidade de $H$. pylori na mucosa antral.

Conclui-se que os níveis de anticorpos lgG anti-H. pylori se correlacionam com os graus de gastrite na mucosa antral, evidenciados pela infiltração de neutrófilos, por células mononucleares e atrofia, bem como pela densidade de $H$. pylori.

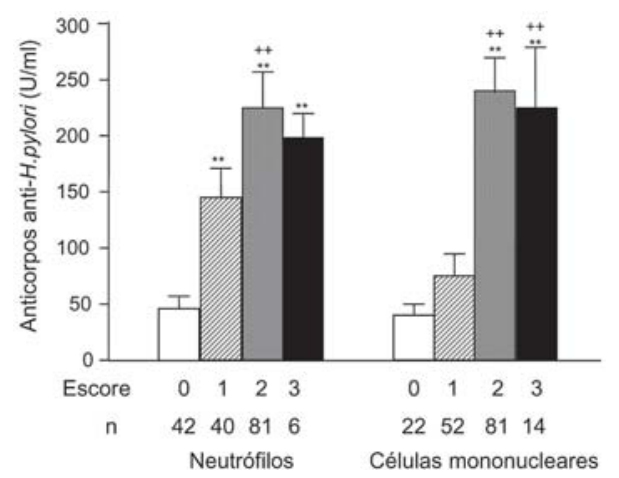




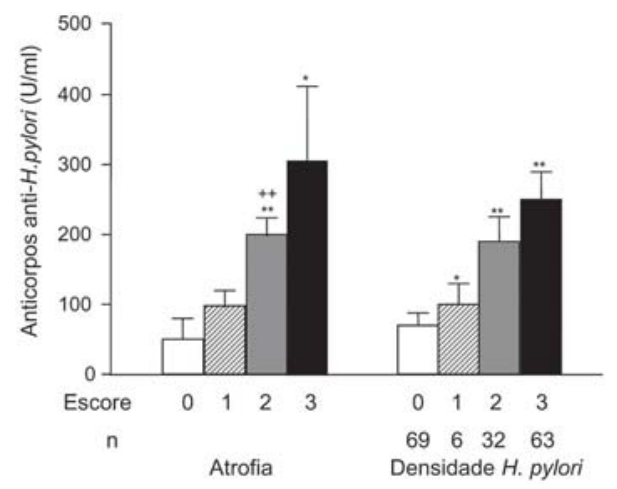

Figura 6.13 - Comparação entre os níveis de anticorpos IgG anti-H. pylori em grupos baseados em escores de quatro características histológicas da mucosa antral. Escores: 0 (normal), 1 (leve), 2 (moderada) e 3 (grave). Cada coluna representa a média \pm 0 erro padrão da média. ${ }^{* \star} P<0,01$ comparado ao escore de $0 ;{ }^{* \star} P<0,01$ comparado ao escore de 1.

Fonte: Adaptado de Chen et al. (2002)

\section{Regressão}

A análise de regressão - termo usado pelos estatísticos com o significado da palavra função em matemática - traduz o melhor modelo matemático para representar a relação entre duas variáveis. Uma variável é considerada dependente $(\mathrm{y})$ porque seu valor varia conforme a variável independente $(x)$. Logo, diz-se que $y$ é função de $x$ ou, em termos estatísticos, regressão de y sobre $x$. A forma mais comum de regressão é a linear: o modelo matemático é uma linha reta.

A equação da regressão é a da reta. Nela, o valor médio de (y) é função de (x), ou seja, y = a + bx, em que (a) representa a inclinação da reta (distância acima da linha basal, onde a reta corta o eixo y) e (b) representa o coeficiente de regressão (quantas vezes a alteração em $x$ dará alteração correspondente em y).

O exemplo citado na Figura 6.11 refere-se a uma só variável independente, mas com freqüência muitas variáveis podem estar envolvidas, como nos casos de regressão múltipla. Por outro lado, outros modelos de regressão representam relação não linear entre as variáveis, como as regressões polinomial, logística e proporcional.

\section{Teste exato de Fisher}

O teste exato de Fisher constitui técnica não paramétrica bastante útil à análise de dados discretos (nominais ou ordinais), quando o tamanho das duas amostras independentes é pequeno. 
É utilizado quando os escores das duas amostras aleatórias independentes se enquadram em uma ou outra de duas classes mutuamente exclusivas (sim/não, positivo/negativo). Em outras palavras, para cada indivíduo, em ambos os grupos, é atribuído um dentre dois escores possíveis - representados por freqüências em uma tabela de contingência $2 \times 2$.

Ao se analisar a significância da diferença de mortalidade entre os dois grupos (Tabela 6.13), pode-se observar que, pelo teste do qui-quadrado, o valor de $P$ foi igual a 0,047 ; portanto, é significante a diferença da taxa de mortalidade entre os dois grupos. Entretanto, no teste exato de Fisher, verificou-se que o valor de $P$ foi igual a 0,068 , ou seja, não existe diferença na taxa de mortalidade entre os dois grupos estudados. Com esse exemplo, ilustra-se a importância da utilização do teste exato de Fisher quando uma das células da tabela de contingência for menor que cinco.

TABELA 6.13 - Mortalidade entre pacientes infectados por MRSA e MSSA no HC-UFU

\begin{tabular}{|c|c|c|}
\hline MORTALIDADE & $\begin{array}{l}\text { MRSA } \\
n=34\end{array}$ & $\begin{array}{c}\text { MSSA } \\
n=100\end{array}$ \\
\hline NÃO & 30 & 97 \\
\hline SIM & 4 & 3 \\
\hline
\end{tabular}

MRSA = Staphylococcus aureus resistentes à meticilina MSSA $=$ Staphylococcus aureus sensíveis à meticilina

Cálculos do $P$ :

Qui-quadrado: $P=0,047$

Exato de Fisher: $P=0,068$

Em caso de células com valores superiores a cinco, quando deve ser usado o qui-quadrado ou o teste exato de Fisher? Em tabelas de contingência $2 \times 2$, pode-se escolher qualquer um dos testes. Entretanto, o segundo será sempre a melhor escolha porque fornece o valor exato de $P$. O primeiro é de cálculo mais simples, mas para pequenos números nas células o valor de $P$ é sempre aproximado quando seu calculo é feito em um programa computacional, em geral pela correção de continuidade de Yates - também denominada correção de Yates. Assim, considerando que somente com números grandes os valores de $P$ obtidos pelo qui-quadrado e pelo teste exato de Fisher são similares, recomenda-se evitar o qui-quadrado quando os números na tabela de contingência são pequenos. 
O teste de Wilcoxon - ou teste da somatória de ranqueamento de Wilcoxon (Wilcoxon Signed Rank Sum Test) - é do tipo não paramétrico e utilizado na comparação de dados pareados em variáveis ordinais, intervalares ou de razão. Comparado ao $t$ de Student pareado, o teste de Wilcoxon tem $95 \%$ de poder e permite determinar se duas amostras pareadas não muito pequenas (no mínimo seis pares) são significativamente diferentes. Quando essas diferenças são grandes, também é grande a probabilidade de elas não serem ao acaso, e sim resultarem de um fator causal. Ao contrário, se forem pequenas, existe grande possibilidade de tais diferenças serem ao acaso.

Um exemplo do cálculo desse teste está demonstrado na Tabela 6.14, com dez pares de informações. Para cada indivíduo (coluna 1), foi medida a produção feita quando a iluminação estava alta (coluna 2) e quando estava baixa (coluna 3).

TABela 6.14 - Ordenação de dados para o cálculo do teste de Wilcoxon

\begin{tabular}{|c|c|c|c|c|c|c|}
\hline Indivíduos & $\begin{array}{c}\text { Alta } \\
\text { Iluminação }\end{array}$ & $\begin{array}{c}\text { Baixa } \\
\text { Iluminação }\end{array}$ & Diferença & Ordem & $\begin{array}{c}\text { Positivo } \\
(T+)\end{array}$ & $\begin{array}{c}\text { Negativo } \\
\text { (T-) }\end{array}$ \\
\hline 1 & 26 & 21 & 5 & 7.5 & 7.5 & \\
\hline 2 & 22 & 19 & 3 & 3.5 & 3.5 & \\
\hline 3 & 18 & 19 & -1 & 1 & & 1 \\
\hline 4 & 18 & 12 & 6 & 9.5 & 9.5 & \\
\hline 5 & 16 & 10 & 6 & 9.5 & 9.5 & \\
\hline 6 & 14 & 16 & -2 & 2 & & 2 \\
\hline 7 & 15 & 10 & 5 & 7.5 & 7.5 & \\
\hline 8 & 13 & 10 & 3 & 3.5 & 3.5 & \\
\hline 9 & 11 & 7 & 4 & 5.5 & 5.5 & \\
\hline \multirow[t]{2}{*}{10} & 10 & 6 & 4 & 5.5 & 5.5 & \\
\hline & & & & & $T_{p}=52$ & $T_{n}=3$ \\
\hline
\end{tabular}

Com base nos dados coletados:

- calcular a diferença dessas duas medidas (coluna 4). Quando, em algum dos pares, a diferença for igual a zero $(d=0)$, eles não receberão ranks; por conseqüência, para o cálculo de n (Quadro 6.1), deve-se subtrair do número total de pares aqueles cujas diferenças foram iguais a zero;

- ordenar esses valores sem levar em conta o sinal (coluna 5). Assim, nesse exemplo, o menor valor é aquele relativo à terceira linha. Além disso, para levar em conta os empates, faz-se a média das posições, como no caso das colunas 9 e 10, que empatam na quinta e na sexta posição: ambas recebem o valor 5,5 . Nesse exemplo, em particular, existem quatro empates;

- separar as ordens atribuídas em função dos valores cuja diferen- 
ça era positiva (coluna 6) daqueles cuja diferença era negativa (coluna 7);

- somar os ranks das diferenças positivas $(T+)$ e o das diferenças negativas (T-);

- selecionar entre T+ e T- o de menor valor, que será então denominado de $T\left(T=\operatorname{Mín}\left\{T_{p}, T_{n}\right\}\right)$ - nesse exemplo é o valor 3 ( $\left.T_{\text {calculado }}\right)$; - o valor de T é comparado com os dados da tabela de Wilcoxon encontrada comumente em livros de estatística e apresentada, de maneira compacta, no Quadro 6.1. Para acessar essa tabela, é necessário usar $\mathrm{N}$ como o número de pares (eliminando-se aqueles em que a diferença é zero) e o nível de significância (a); nesse exemplo, para $\mathrm{N}=10$ e $a=0,01$, a tabela fornece o valor $3\left(T_{\text {critico }}\right)$ - aquele obtido ao se calcular o $\mathrm{T}$ de Wilcoxon;

- comparar $\mathrm{T}_{\text {calculado }}$ com $\mathrm{T}_{\text {critico }}$ e tomar a decisão de aceitar ou rejei$\operatorname{tar} \mathrm{H}_{0}$.

Assim, pode-se inferir que nesse exemplo há diferença significativa entre a produção com alta iluminação comparada com a de baixa iluminação.

\begin{tabular}{|c|c|c|}
\hline $\mathbf{N}$ & $\mathbf{0 , 0 5}$ & $\mathbf{0 , 0 1}$ \\
\hline $\mathbf{6}$ & 1 & - \\
$\mathbf{7}$ & 2 & - \\
$\mathbf{8}$ & 4 & - \\
$\mathbf{9}$ & 6 & 2 \\
$\mathbf{1 0}$ & 8 & 3 \\
$\mathbf{1 1}$ & 11 & 5 \\
$\mathbf{1 2}$ & 14 & 7 \\
$\mathbf{1 3}$ & 17 & 10 \\
$\mathbf{1 4}$ & 21 & 13 \\
$\mathbf{1 5}$ & 25 & 16 \\
$\mathbf{2 0}$ & 52 & 37 \\
$\mathbf{2 5}$ & 90 & 68 \\
$\mathbf{3 0}$ & 137 & 109 \\
\hline
\end{tabular}

Quadro 6.1 - Distribuição dos valores críticos do teste de Wilcoxon

Observa-se que, se os grupos forem muito diferentes, a maior parte das diferenças terá o mesmo sentido, e serão sobretudo as pequenas diferenças que terão sentidos opostos. Assim, a soma $T$ das diferenças de sinal menos freqüente é pequena; logo, quanto menor for esse valor, mais significativo será o teste. No exemplo considerado, se o valor encontrado na tabela fosse dois, não se teria obtido significância nesse teste.

Na tomada de decisão, é preciso levar em conta a formulação do teste de hipóteses, em que: 


\section{1) teste bicaudal:}

$-\mathrm{H}_{0}$ : não há diferença entre as produções com alta ou baixa iluminação;

- $\mathrm{H}_{1}$ : há diferença entre as produções com alta ou baixa iluminação.

Se $\mathrm{T}_{\text {calculado }} \leq \mathrm{T}_{\text {critico }} \Rightarrow$ rejeita-se $\mathrm{H}_{0}$.

\section{2) teste monocaudal:}

- $\mathrm{H}_{0}$ : as produções com alta iluminação são menores ou iguais àquelas com baixa iluminação;

$-\mathrm{H}_{1}$ : as produções com alta iluminação são maiores àquelas com baixa iluminação.

Nesse caso T+ é maior que T-, sendo que T- será escolhido como T. Se $\mathrm{T}-\leq \mathrm{T}_{\text {crítico }} \Rightarrow$ rejeita-se $\mathrm{H}_{0}$.

Alternativamente, as hipóteses do teste monocaudal poderiam ser formuladas assim:

- $\mathrm{H}_{0}$ : as produções com baixa iluminação são menores ou iguais àquelas com alta iluminação;

- $\mathrm{H}_{1}$ : as produções com baixa iluminação são maiores que aquelas com alta iluminação.

Nesse caso T- é maior que $T+$, sendo que $T+$ será escolhido como $T$. Se $\mathrm{T}+\leq \mathrm{T}_{\text {crítico }} \Rightarrow$ rejeita-se $\mathrm{H}_{0}$

\section{Análise de variância de Kruskal-Wallis}

Trata-se de um teste não paramétrico para três ou mais grupos não pareados que comprova se um determinado número de amostras independentes pode ter sido extraído da mesma população. Essa prova é mais eficiente que o teste da mediana, pois utiliza, de modo mais completo, as informações contidas nas observações, visto que os escores são convertidos em postos, enquanto aquele apenas separa os elementos em função da mediana.

Como a ANOVA, o teste de Kruskal-Wallis avalia se três ou mais amostras são iguais ou diferentes. Entretanto, ao contrário dela, pode ser usado onde não há distribuição normal e homogeneidade das variâncias, bem como no caso de amostras não tomadas ao acaso. Um exemplo da aplicabilidade e do cálculo do teste de Kruskal-Wallis está demonstrado na Tabela 6.15 , onde se pretende avaliar a influência da variável massa corporal em três grupos de pessoas definidos segundo o consumo diário de lipídios e refrigerantes em suas dietas (pouco, moderado e muito). 
TABELA 6.15 - Massa corporal $(\mathrm{kg})$ relacionada com a ingestão diária de lipídios e refrigerantes (pouco, moderado e muito)

\begin{tabular}{ccc}
\hline Pouco & Moderado & Muito \\
\hline 90 & 81 & 116 \\
120 & 122 & 145 \\
80 & 130 & 146 \\
62 & 132 & 131 \\
99 & 109 & 123 \\
98 & 118 & 124 \\
160 & & \\
\hline
\end{tabular}

Após a atribuição dos postos ou ranks para cada observação, deve-se fazer a soma dos postos de cada grupo (Rj) e calcular $(\mathrm{Rj})^{2} / \mathrm{nj}$, onde nj representa o número de indíviduos por grupo. Obtêm-se, assim, os dados da Tabela 6.16.

TABeLA 6.16 - Transformação dos escores da Tabela 6.15 em postos e cálculos preliminares

\begin{tabular}{cccccc}
\hline \multicolumn{2}{c}{ Pouco } & \multicolumn{2}{c}{ Moderado } & \multicolumn{2}{c}{ Muito } \\
\hline $\begin{array}{c}\text { Massa } \\
\text { corporal }\end{array}$ & Rank & $\begin{array}{c}\text { Massa } \\
\text { corporal }\end{array}$ & Rank & $\begin{array}{c}\text { Massa } \\
\text { corporal }\end{array}$ & Rank \\
\hline 90 & 4 & 81 & 3 & 116 & 8 \\
120 & 10 & 122 & 11 & 145 & 17 \\
80 & 2 & 130 & 14 & 146 & 18 \\
62 & 1 & 132 & 16 & 131 & 15 \\
99 & 6 & 109 & 7 & 123 & 12 \\
98 & 5 & 118 & 9 & 124 & 13 \\
160 & 19 & - & - & - & - \\
& & & 60 & & 83 \\
$R j$ & 47 & & 3600 & & 6889 \\
$\mathbf{R j}$ & 2209 & & 6 & & 6 \\
$\mathbf{n j}$ & 7 & & 600,0 & & 1148,16 \\
$\mathbf{R j}^{2} / \mathbf{n j}$ & 315,57 & & & &
\end{tabular}

Em seguida, deve-se calcular a estatística $H$ em que se usam as somas das colunas para que se possa inferir a existência ou não de diferença entre os grupos através da tomada de decisão.

$$
H=\frac{12}{N \cdot(N+1)} \cdot \sum_{j} \frac{R_{j}^{2}}{n_{j}}-3 \cdot(N+1)
$$

onde:

nj = número de elementos do grupo;

$\mathrm{N}$ = número total de observações dos k grupos;

$\mathrm{Rj}=$ soma dos postos ou ranks.

$$
H=\frac{12}{19 \cdot(19+1)} \cdot\left(\frac{47^{2}}{7}+\frac{60^{2}}{6}+\frac{83^{2}}{6}\right)-3 \cdot(19+1)=5,17
$$


No teste de Kruskal-Wallis, o teste de hipóteses é:

$-\mathrm{H}_{0}$ : não há diferença entre os grupos analisados;

$-\mathrm{H}_{1}$ : pelo menos um dos grupos é diferente.

E a tomada de decisão segue assim:

1) quando há três grupos com número pequeno de casos $(\mathrm{k}=3 \mathrm{e}$ $\mathrm{nj} \leq 5$ ), pesquisar na tabela dos limites de probabilidade da distribuição de $\mathrm{H}\left(\mathrm{H}_{\text {critico }}\right)$ no teste Kruskal-Wallis, de acordo com o número de grupos analisados, tem-se que:

$\mathrm{Se} \mathrm{H}_{\text {calculado }}<\mathrm{H}_{\text {critico }} \Rightarrow$ rejeita-se $\mathrm{H}_{0}$

2) quando há mais de três grupos ou quando eles têm grande número de casos ( $\mathrm{k}>3$ ou $\mathrm{nj}>5$ ), $\mathrm{H}$ tem distribuição de qui-quadrado com k-1 graus de liberdade; sabendo-se o qui-quadrado crítico, tem-se que:

Se $\mathrm{H}_{\text {calculado }} \geq \mathrm{X}_{\text {critico }}^{2} \Rightarrow$ rejeita-se $\mathrm{H}_{0}$.

No exemplo acima, como há mais de cinco elementos em cada grupo, usa-se a tabela do qui-quadrado para se verificar a significância do valor $\mathrm{H}$ calculado. Nesse caso, com dois graus de liberdade (k-1), a significância está compreendida entre 0,10 e 0,05 - o que deve ser interpretado como não-existência de diferença entre os três grupos, pois valor de $P$ é maior que 0,05 .

\section{Dupla anÁlise de VARIÂNCIA de Friedman}

Trata-se de teste não paramétrico que compara três ou mais grupos de amostras pareadas. Quando os dados de k amostras pareadas se apresentam, pelo menos, em escala ordinal, a prova de Friedman é útil para se comprovar a hipótese de nulidade de que as k amostras tenham sido extraídas de uma mesma população. Os dados são transformados em postos, e o teste determina a probabilidade de as diferentes colunas de postos terem vindo de uma mesma população. Por exemplo, suponha que se queira estudar os escores de três indivíduos sob quatro condições diferentes ( $k=$ 4 e $\mathrm{N}=3$ ). Assim, três estudantes ( $\mathrm{A}, \mathrm{B}, \mathrm{C})$ ordenam quatro estágios de uma linha de montagem (I, II, III e IV) - conforme mostrado a Tabela 6.17.

TABELA 6.17 - Escores de três grupos correspondentes sob quatro condições

\begin{tabular}{ccccc}
\hline \multirow{2}{*}{ Grupos } & \multicolumn{4}{c}{ Condições } \\
\cline { 2 - 5 } & I & II & III & IV \\
\hline A & 9 & 4 & 1 & 7 \\
B & 6 & 5 & 2 & 8 \\
C & 9 & 1 & 2 & 6 \\
\hline
\end{tabular}


Para se aplicar a prova de Friedman a esses dados, primeiro atribuem-se postos aos escores em cada linha: ao mais baixo, pode-se atribuir o posto 1; ao seguinte, o posto 2, etc. Obtêm-se, assim, os dados da Tabela 6.18.

TABela 6.18 - Postos correspondentes aos escores da Tabela 6.17

\begin{tabular}{ccccc}
\hline \multirow{2}{*}{ Grupos } & \multicolumn{4}{c}{ Condições } \\
\cline { 2 - 5 } & I & II & III & IV \\
\hline A & 4 & 2 & 1 & 3 \\
B & 3 & 2 & 1 & 4 \\
C & 4 & 1 & 2 & 3 \\
Total & 11 & 5 & 4 & 10 \\
\hline
\end{tabular}

Para se testar a hipótese de nulidade (se todas as amostras - colunas - provêm da mesma população), quando o número de linhas e/ou colunas não é muito pequeno, pode-se mostrar que tem distribuição quase igual à do qui-quadrado, com graus de liberdade $(\mathrm{gl})=\mathrm{k}-1$. Seu valor é dado pela fórmula:

$$
\chi_{F}^{2}=\frac{12}{N \cdot k \cdot(k+1)} \cdot \sum_{j} R_{j}^{2}-3 \cdot N \cdot(k+1)
$$

onde:

$N=$ número de linhas:

$K=$ número e colunas;

$R j=$ somas dos postos ou ranks.

Utilizando esta fórmula, obtém-se:

$$
x_{F}^{2}=\frac{12}{3 \cdot 4 \cdot(4+1)} \cdot[121+25+16+100]-3 \cdot 3 \cdot(4+1)=7,4
$$

Como a probabilidade associada a $\chi_{F}^{2} \geq 7,4$, quando $\mathrm{k}=4$ e $\mathrm{N}=3$, é $P=0,033$, com tais dados, portanto, pode-se rejeitar a hipótese de nulidade de que as quatro amostras tenham sido extraídas da mesma população com respeito à locação (postos médios), em nível de significância de 0,05.

\section{CONCLUSÃO}

Buscou-se, neste capítulo, oferecer ao leitor a noção do nível de significância de resultados obtidos em testes estatísticos. Com base nesse conceito, aquele que se servir de testes - paramétricos ou não - deverá sempre ter o cuidado de apresentar resulta- 
dos associados a uma certa probabilidade de erro. Quanto menor for esse valor, mais significativo será o resultado.

Deve-se ressaltar, aqui, a importância na escolha do teste e, sobretudo, o correto delineamento da pesquisa em termos das variáveis utilizadas. Cuidados especiais devem ser tomados quando se usam dados pareados.

Um sumário da aplicação dos testes estatísticos em diferentes estudos pode ser visualizado no Quadro 6.2.

\begin{tabular}{|lll|}
\hline Dados & Amostras pareadas & Amostras independentes \\
\hline Nominais & - Teste do sinal $(n<25)$ & - Teste do Qui-Quadrado $(n>5)$ \\
& - Teste de McNemar $(n \geq 25)$ & - Teste exato de Fisher $(n \leq 5)$ \\
Ordinais & - Dupla Análise de Variância de & - Análise de Variância de \\
& Friedman (two-way ANOVA) & Kruskal-Wallis $($ one-way ANOVA) \\
& - Teste de Wilcoxon & - Teste U de Mann-Whitney \\
Intervalares & - Teste $t$ de Student & - Teste $t$ de Student \\
& & (para duas amostras) \\
\hline
\end{tabular}

Quadro 6.2 - Aplicação de testes estatísticos em diferentes estudos

Para se verificar a veracidade estatística de uma hipótese, todo cuidado é pouco na escolha da amostra. Também é preciso dizer que a estatística não é infalível.

\section{REFERÊNCIAS}

BEAGLEHOLE, R.; BONITA, R.; KJELLSTRÖM, T. Basic epidemiology. Geneva: World Health Organization, 1994. 175p.

BERQUÓ, E .S. Bioestatística. São Paulo: Pedagógica Universitária, 1981. 350p.

CHEN, T. S. et al. Immunoglobulin G antibody against Helicobacter pylori: clinical implications of levels found in serum. Clinical and Diagnostic Laboratory Immunology, Washington, v. 9, n. 5, p. 1.044-1.048, 2002.

COSTA, S. F. Introdução ilustrada à estatística. 2. ed. São Paulo: Harbra, 1992.

CRESPO, A. A. Estatística fácil. 15. ed. São Paulo: Saraiva, 1997. 224p.

ESSEX-SORLIE, D. Medical biostatistics and epidemiology. Norwalk: Appleton and Lange, 1995. 
ESTATÍSTICA. In: FERREIRA, A. B. de H. Novo dicionário da língua portuguesa. 2. ed. rev. aum. Rio de Janeiro: Nova Fronteira, 1986. p. 717.

FLETCHER, R.H.; FLETCHER, S.W.; WAGNER, E.H. Epidemiologia clínica: elementos essenciais. 3. ed. Porto Alegre: Artes Médicas, 1996. 281p.

GUEDES, M. L. S.; GUEDES, J. S. Bioestatística para profissionais de saúde. Rio de Janeiro: Ao Livro Técnico, 1988. 201p.

HOFFMANN, R.; VIEIRA, S. Elementos de estatística. 2. ed. São Paulo: Atlas, 1990. 159p.

JORGE, M. T.; RIBEIRO, L. A. Fundamentos para o conhecimento científico: áreas de saúde. São Paulo: CLR Balieiro, 1999. 106 p. NAZARETH, H. Curso básico de estatística. 5. ed. São Paulo: Ática, 1992.

ROUQUAYROL, M. Z. (Ed). Epidemiologia e saúde. 3. ed. Rio de Janeiro: MEDSI, 1988. 492p.

SILVA, D. A. O. et al. Heterologous antibodies to evaluate the kinetics of humoral immune response in dogs experimentally infected with Toxoplasma gondii RH strain. Veterinary Parasitology, Amsterdan, v. 107, n. 3, p. 181-195, 2002.

SOARES, J. F; FARIAS, A. A.; CESAR, C. C. Introdução à estatística. Rio de Janeiro: Guanabara Koogan, 1991. 378p.

SPINELLI, W.; SOUZA, M. H. S. Uma introdução à estatística. São Paulo: Ática, 1990. 159p.

SWINSCOW, T. D. V. Statistics at square one. 7th ed. London: British Medical Association, 1980. 86p.

TOOTHAKER, L. E.; MILLER, L. Introductory statistical: for the behavioral sciences. Pacific Grove: Cole, 1996.

TRIOLA, M. F. Introdução à estatística. Tradução de Alfredo Alves de Faria. 7. ed. Rio de Janeiro: LTC, 1999. 410p. 


\section{PARTE III}

\section{MÉTODOS DE ANÁLISE \\ EM DIFERENTES TIPOS DE ESTUDOS}




\title{
MÉTODOS DE ANÁLISE EM ESTUDOS SOBRE CAUSALIDADE
}

\author{
Deise Aparecida de Oliveira Silva
}

\section{INTRODUÇÃO}

O presente capítulo objetiva mostrar métodos de análise em estudos epidemiológicos específicos, em particular naqueles relacionados com causalidade, ou seja, com as considerações sobre a relação entre causa e efeito. Assim, os conceitos de causa, associação causal, bem como de diferentes fatores de risco envolvidos nesse tipo de estudo, são aqui definidos e analisados. Também são apresentados e discutidos as técnicas ou os cálculos estatísticos mais utilizados para se determinarem tais associações como risco relativo (RR), risco atribuível (RA) e razão de chances (OR: odds ratio).

\section{CAUSA}

O conceito de causa é controverso: os significados diferem em vários contextos, e não há definição apropriada em todas as ciências. Em geral, causa é definida como algo que desencadeia um efeito ou um resultado. Estudos epidemiológicos sobre causalidade são importantes para se conhecerem as causas de doenças e, logo, para uma conduta adequada nas áreas de prevenção, diagnóstico e tratamento.

Propostos em 1882, os postulados de Koch para determinar se um agente infeccioso causa doença contribuíram muito para a definição do conceito de causa na área biomédica. São eles:

1) o organismo deve estar presente em todos os casos da doença;

2) o organismo deve ser isolado e crescer em cultura pura;

3) o organismo deve, quando inoculado em um animal susceptível, causar a doença específica;

4) o organismo deve então ser recuperado do animal e identificado. 
Entretanto, a causa da maioria das doenças não pode ser estabelecida por meio da relação "uma causa-uma doença", pois muitos fatores em conjunto determinam a conhecida rede de causalidade. Assim, a causa de uma doença é uma condição ou característica que tem papel relevante na produção dela e deve precedê-la. Quando inicia a doença, é chamada de causa suficiente; se a doença não se desenvolve sem sua presença, é chamada de causa necessária. Por exemplo, o tabagismo é um dos componentes da causa suficiente do câncer de pulmão, embora apenas pequena parte de indivíduos tabagistas possa desenvolver a doença, pois outros fatores desconhecidos são requeridos. Mas é inegável que a interrupção do tabagismo reduz o número de casos de câncer pulmonar em uma população.

Por outro lado, cada causa suficiente tem um componente de causa necessária. Por exemplo, em um surto de infecção alimentar, salada de frango com maionese foi a causa suficiente de diarréia por Salmonella, mas a presença deste microorganismo constitui a causa necessária da doença. Portanto, em doenças infecciosas, a presença de um organismo é necessária, mas não suficiente para que ocorra a doença. Outro exemplo clássico é a AIDS, que não pode ocorrer sem que haja exposição ao vírus da imunodeficiência humana (HIV), mas a exposição ao vírus não resulta necessariamente em doença.

Nesse sentido, conceitos de causa devem ser mais amplamente aplicados, considerando-se não só as causas únicas ou os mecanismos patogênicos, mas também as causas múltiplas ou fatores de risco não específicos que se interagem para formar a rede de causalidade e são importantes para disseminação e controle de doenças. Por exemplo, a tuberculose é provocada pelo bacilo Mycobacterium tuberculosis, mas a susceptibilidade do hospedeiro, o nível de exposição, as condições socioeconômicas, a desnutrição, a vacinação e as características genéticas constituem fatores muito importantes no processo de causa da doença - e devem ser investigados quando o objetivo é controlá-los.

\section{INTERAÇÃO ENTRE CAUSAS MÚLTIPLAS}

Quando múltiplos fatores causais interagem entre si, podem contribuir ou não para o processo de desenvolvimento da doença; no entanto, este processo depende do tipo de interação entre aqueles fatores. Assim, o efeito resultante pode ser maior (sinergia) ou menor (antagonismo) que o esperado pela simples combinação dos efeitos individuais de cada causa. A Figura 7.1 mostra um exemplo típico, em que vários fatores, isolados ou em combinação, podem atuar so- 
bre o risco de desenvolvimento de doença cardiovascular em homens. A interferência em dois desses fatores - por exemplo, tratar a hipertensão e deixar de fumar - poderia ter impacto substancial na diminuição do risco de homens desenvolverem doença cardiovascular, mesmo na presença de outros fatores causais.

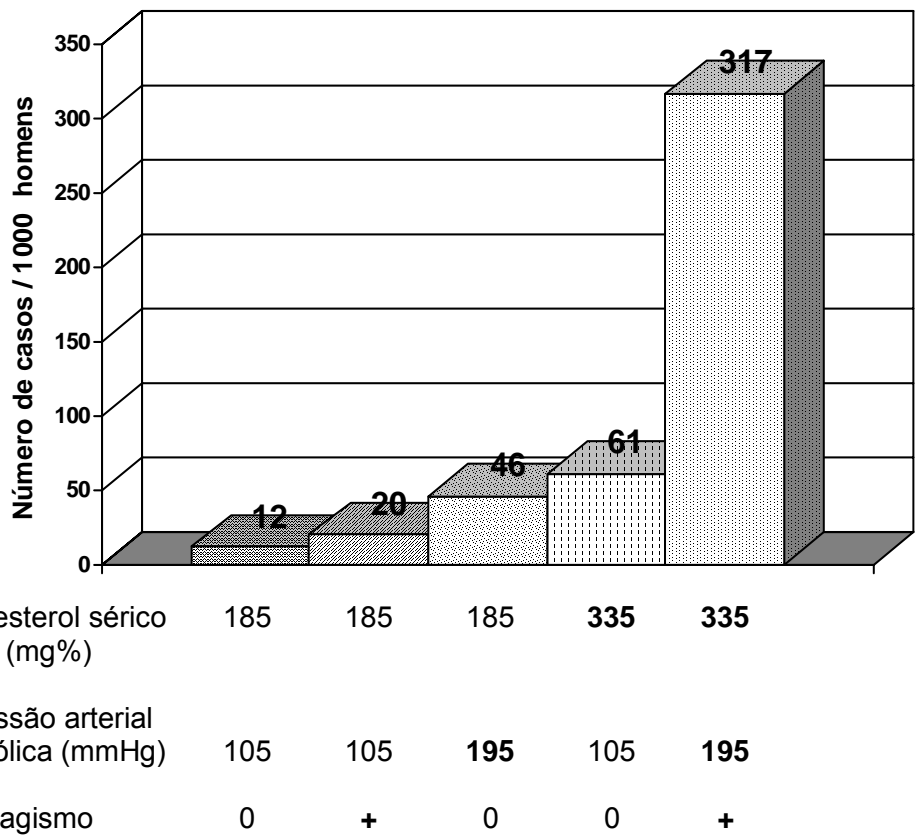

FIgURA 7.1 - Interação entre causas múltiplas de doença. Risco de desenvolver doença cardiovascular em homens de acordo com os níveis de vários fatores de risco, isolados e em combinação. Valores anormais são grafados em negrito Fonte: Adaptado de Fletcher, Fletcher e Wagner (1996).

\section{FATORES DE RISCO}

O termo fator de risco é usado, em geral, para descrever características positivamente associadas com risco de desenvolvimento de doença ou evento e que podem ou não, de forma isolada, ser suficientes para causar a doença. Assim, é possível que alguns fatores de risco separadamente - como o tabagismo - estejam associados com várias doenças (doença pulmonar obstrutiva crônica, doença arterial coronariana, câncer de pulmão e outras). Por outro lado, algumas doenças, a exemplo da doença arterial coronariana, podem estar associadas com vários fatores de risco (tabagismo, hipertensão, hipercolesterolemia e hereditariedade), os quais, isoladamente, parecem incapazes de induzir a doença. Assim, estu- 
dos epidemiológicos podem determinar a contribuição relativa de cada fator para a ocorrência da doença, e a conseqüente potencial redução da doença com a eliminação de cada fator de risco.

Os fatores de risco podem ser:

- genéticos - genes específicos constituem fatores de risco para várias doenças (câncer de cólon, osteoporose, espondilartropatias, dentre outras);

- físicos, químicos e biológicos - radiações ionizantes, drogas, agentes infecciosos, toxinas e outros;

- sociais - estresse, luto pela perda do cônjuge, mudanças bruscas de rotina, dentre outros;

- comportamentais - consumo excessivo de bebidas alcoólicas, promiscuidade sexual, tabagismo, uso de drogas e outros.

Quatro tipos de fatores podem estar envolvidos na causa de doenças. Todos podem ser necessários, mas raramente são suficientes para causar uma doença em particular. São eles:

1) fatores predisponentes: induzem um estado de susceptibilidade do hospedeiro à doença, por exemplo: idade, doenças anteriores e sexo;

2) fatores facilitadores: favorecem o desenvolvimento da doença, a exemplo da baixa condição socioeconômica, desnutrição, falta de saneamento básico, assistência médica inadequada, dentre outros; 3) fatores desencadeantes: estão associados com a instalação da doença, por exemplo: exposição aos agentes biológicos específicos (bactérias, parasitas, vírus);

4) fatores agravantes: agravam uma doença estabelecida, por exemplo: exposição repetida ao agente específico.

\section{ASSOCIAÇÃO CAUSAL}

Refere-se ao processo de determinar se associações observadas são causais, ou seja, se há relação entre uma possível causa e um efeito. Antes de analisar a associação para a possibilidade de ser causal, outras explicações - tais como acaso, viés de seleção e aferição ou fator de confusão/confundimento (confounding) devem ser excluídas (Figura 7.2). Dessa forma, uma associação pode ser: artificial, quando resultar de vieses na seleção dos participantes ou na aferição dos dados do estudo; indireta, quando resultar de outras características que estão intrinsecamente associadas ao fator de risco ou à doença em estudo (fator de confusão ou acaso); causal, quando resultar da interação entre fatores etiológicos e de risco para o desenvolvimento da doença. 


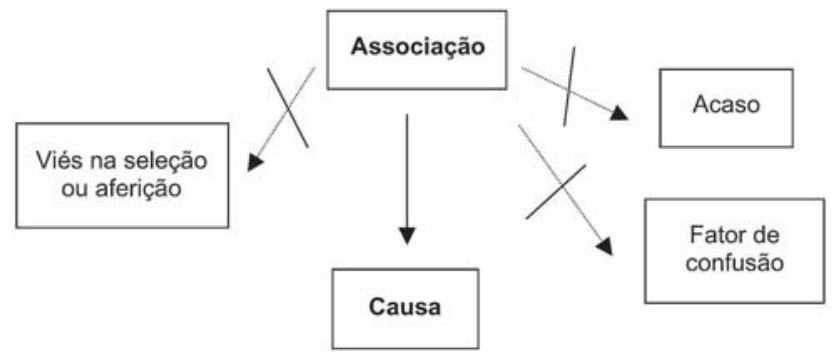

Fıgura 7.2 - Representação esquemática das diferentes possibilidades de associação entre fatores de risco (exposição) e doença (evento)

Um conjunto de critérios estabelecido, desde 1965, pelo estatístico britânico Sir Austin Bradford-Hill tem sido bastante utilizado para julgar se dada relação entre causa e efeito é causal ou apenas associação. Dentre eles, destacam-se, de forma resumida: 1) temporalidade ou relação temporal: a causa (exposição) deve sempre preceder o efeito, sobretudo em estudos transversais e de caso-controle, nos quais a causa e o efeito são avaliados ao mesmo tempo;

2) reprodutibilidade ou consistência da associação: resultados semelhantes são demonstrados em diversos estudos, em tempos e locais diferentes e em diferentes populações;

3) intensidade ou força da associação: uma forte associação (expressa por um alto valor numérico de risco relativo ou risco absoluto) é mais provável ser causal que uma fraca associação (baixo valor numérico do risco), que pode ser influenciada por viés ou fator de confusão;

4) especificidade: uma causa deve estar relacionada com um efeito (observável geralmente em doenças agudas), mas há muitas causas para o mesmo efeito ou muitos efeitos relativos à mesma causa (em geral, visto em doenças crônico-degenerativas);

5) relação dose-resposta: variações na quantidade de exposição estão associadas com variações na incidência do efeito;

6) reversibilidade: a remoção de uma possível causa reduz o efeito ou risco da doença;

7) plausibilidade biológica: os resultados devem ser coerentes com os conhecimentos existentes na época e validados em pesquisas anteriores;

8) analogia: relação de causa e efeito já estabelecida em outros exemplos semelhantes.

Nem todos esses critérios têm o mesmo valor na decisão sobre causalidade. Um critério presente fortalece a associação causal; se ausente, outras evidências devem ser verificadas.

$\mathrm{Na}$ análise crítica de artigos científicos sobre causalidade, 
algumas questões referentes a esses critérios devem ser consideradas e respondidas pelo leitor para constatação de que os resultados refletem, de fato, uma associação causal:

- Há evidência de experimentos reais em seres humanos ou em animais de experimentação?

- A associação é forte?

- A associação é consistente de estudo para estudo?

- A relação temporal é correta?

- Existe relação entre intensidade da exposição e freqüência ou intensidade da doença?

- A associação faz sentido epidemiologicamente? A associação faz sentido biologicamente?

- A associação é específica?

- A associação é análoga a uma associação causal previamente demonstrada?

Em algumas situações, ocorre associação entre exposição a um determinado fator (causa) e doença (efeito) chamada causalidade reversa, em que o efeito (doença) induz a exposição ao fator (causa). Como exemplo, pode-se observar a associação entre o uso de ácido acetilsalićlico (aspirina) e doenças crônicas que provocam cefaléia não porque o uso da aspirina leva à doença, mas porque a doença leva ao uso desse medicamento.

\section{MEDIDAS DE ASSOCIAÇÃO}

Em estudos transversais (prevalência comparada), retrospectivos (caso-controle) e prospectivos (coorte), as variáveis analisadas são, em geral, dicotômicas e passíveis de ser combinadas em uma tabela $2 \times 2-$ como mostra a Tabela 7.1.

TABeLA 7.1 - Tabela de associação entre causa (fator de exposição) e efeito (doença)

\begin{tabular}{cccc}
\hline \multirow{2}{*}{$\begin{array}{c}\text { Fator de } \\
\text { exposição }\end{array}$} & \multicolumn{2}{c}{ Doença } & Total \\
\cline { 2 - 3 } & Presente & Ausente & $b$ \\
Sim & $a$ & $d$ & $a+b$ \\
Não & $c$ & $b+d$ & $a+b+c+d$ \\
Total & $a+c$ & & \\
\hline
\end{tabular}

Onde:

$a$ = número de indivíduos expostos ao fator que ficaram doentes;

$b=$ número de indivíduos expostos ao fator que não ficaram doentes;

$c=$ número de indivíduos não expostos ao fator que ficaram doentes; $d=$ número de indivíduos não expostos ao fator que não ficaram doentes. 
Em estudos prospectivos, a relação $a /(a+b)$ representa o coeficiente de incidência da doença entre os indivíduos expostos, e a relação $c /(c+d)$, o coeficiente de incidência entre os indivíduos não expostos.

Dentre as medidas de associação estatística entre exposição a um fator (causa) e doença (efeito), as mais utilizadas em epidemiologia são: risco relativo (RR), risco atribuível (RA) e razão de chances (OR: odds ratio).

\section{Risco ReLativo (RR)}

Mede a chance (ou o risco) de um indivíduo exposto a determinado fator desenvolver certa doença em relação ao indivíduo não exposto. Portanto, RR é o número de vezes que indivíduos expostos estão mais sujeitos que os não-expostos a se tornar doentes. Como a incidência mede o risco de os indivíduos adquirirem a doença em determinado período, o RR representa a razão entre os coeficientes de incidência dos indivíduos expostos (le) e a incidência dos não-expostos (lo):

$$
\mathrm{RR}=\mathrm{le} / \mathrm{lo} \text { ou } \mathrm{RR}=\mathrm{a} /(\mathrm{a}+\mathrm{b}) / \mathrm{c} /(\mathrm{c}+\mathrm{d})
$$

O RR é expresso em número absoluto e representa a força de associação entre o fator (exposição) e a doença (efeito), e sua utilização é comum em estudos de causalidade, em que a probabilidade de uma doença ocorrer pode resultar da ação de um ou mais fatores de risco.

\section{Risco atribuível (RA)}

Mede a incidência adicional da doença após uma exposição - além daquela (incidência basal) por causa de outros fatores experimentada por indivíduos não expostos. Portanto, RA é o excesso de incidência da doença relacionado com a exposição e que representa o quanto o fator de exposição acrescenta ao risco do desenvolvimento da doença. Calculado pela diferença entre os coeficientes de incidência nos indivíduos expostos (le) e não-expostos (lo), o RA é também chamado de diferença de risco:

$$
R A=l e-10 \text { ou } R A=a /(a+b)-c /(c+d)
$$

Em termos de saúde pública, conforme a incidência da doença na população, o RA é, muitas vezes, mais importante que o RR. Assim, doenças de alta incidência podem apresentar baixo valor de RR referente a um dado fator, porém alto RA; inversamente, do- 
enças de baixa incidência podem apresentar alto RR e baixo RA.

Tome-se o exemplo hipotético relatado por Jorge e Ribeiro (1999): ao se analisar o fator de exposição (tabagismo) para determinada doença, verifica-se que se esta ocorre em alta incidência (60\% dos indivíduos expostos ao fumo e $40 \%$ dos não-expostos ao fumo), o RR é de 1,5 e o RA, de $20 \%$. Por outro lado, se a doença ocorre em baixa incidência $(0,1 \%$ dos indivíduos expostos e $0,01 \%$ dos não-expostos), o RR é de 10 , e o RA, de $0,09 \%$.

Portanto, para se calcular o RR e o RA, é necessário que se conheça a incidência da doença na população, com e sem a exposição ao fator de risco em questão. Logo, tais medidas só podem ser determinadas em estudos que avaliem incidência, a exemplo dos estudos de coorte e intervenção ou experimentais.

\section{Razão de chances (OR: Odds Ratio)}

Em estudos transversais (estudos de prevalência), em que a freqüência da doença na população é pequena, ou estudos de caso-controle, nos quais a proporção dos indivíduos doentes (casos) é pré-definida, os casos são representativos de todos os casos da doença na população, e os controles são representativos de todos os casos não-doentes. Nesses estudos, o coeficiente de incidência não é determinável; assim, é possível obter medida de risco semeIhante ao risco relativo (RR) pela comparação da freqüência de exposição entre casos e controles. Tal medida é chamada de odds ratio (OR) - ou razão de chances - e objetiva avaliar se existe associação entre a doença e o fator de exposição, bem como quantificar essa possível associação, calculada com base na relação:

$$
\mathrm{OR} \cong \mathrm{RR}=\mathrm{ad} / \mathrm{bc}
$$

Um exemplo hipotético pode ser demonstrado na Tabela 7.2. O uso de contraceptivos orais em determinada população foi analisado segundo a possibilidade de causar trombose venosa. De 375 pacientes usuárias de contraceptivos orais, 25 apresentaram a doença. De 575 pacientes não usuárias dos contraceptivos orais, cinco apresentaram trombose venosa. Pode-se, então, calcular o risco relativo de haver trombose venosa entre usuárias de contraceptivos orais. 
TABeLA 7.2 - Tabela de associação entre uso de contraceptivos orais (fator de exposição) e trombose venosa (doença)

\begin{tabular}{cccc}
\hline \multirow{2}{*}{$\begin{array}{c}\text { Uso de } \\
\text { contraceptivos } \\
\text { orais }\end{array}$} & \multicolumn{2}{c}{ Trombose venosa } & Total \\
\cline { 2 - 3 } & Presente & Ausente & \\
\hline Sim & $25(\mathrm{a})$ & $350(\mathrm{~b})$ & 375 \\
Não & $5(\mathrm{c})$ & $570(\mathrm{~d})$ & 575 \\
Total & 30 & 920 & 950 \\
\hline
\end{tabular}

Fonte: Adaptado de Rouquayrol (1986).

$$
\mathrm{OR}=\mathrm{RR}=\mathrm{ad} / \mathrm{bc}=14250 / 1750=8,14
$$

Isso significa que o risco relativo de ocorrer trombose venosa entre usuárias de contraceptivos orais é 8,14 vezes maior que entre muIheres que não fazem uso.

De modo geral, um valor de $\mathrm{OR}=1,0$ significa que o fator de exposição não tem efeito sobre a doença, $\mathrm{OR}>\mathbf{1 , 0}$ é considerado fator de risco, e OR < 1,0 é considerado fator de proteção.

Fator de proteção $1,1,0 \quad$ Fator de risco

Porém, o simples cálculo da razão de chances oferece apenas uma estimativa pontual dessa medida; por isso não pode ser utilizado para qualquer inferência, a não ser que se considere a variabilidade amostral e, portanto, os intervalos de confiança (IC 95\%) para a razão de chances. Tais intervalos de confiança são genericamente apresentados entre parênteses $(L I-L S)$, em que $L /$ representa o limite inferior, e $L S$, o limite superior, e indicam que há $95 \%$ de confiança ou certeza de que esse intervalo inclui o verdadeiro risco relativo ou odds ratio.

A inferência sobre o efeito do fator de exposição sobre a doença (evento) pode ser feita do seguinte modo:

- Se a unidade (valor 1,0) estiver dentro do intervalo de confiança (entre LI e LS) $\rightarrow$ não existe associação.

- Se a unidade (valor 1,0 ) estiver acima do LS $\rightarrow$ existe associação do tipo fator de proteção.

- Se a unidade (valor 1,0 ) estiver abaixo do $\mathrm{LI} \rightarrow$ existe associação do tipo fator de risco.

A Tabela 7.3 representa o resumo de um estudo de coorte para avaliar o tempo de cirurgia (fator de exposição) como fator de risco para infecção do sítio cirúrgico (ISC) em pacientes submetidos à cirurgia no Hospital de Clínicas da Universidade Federal de Uberlândia (HC-UFU). 
TABELA 7.3 - Tempo de cirurgia como fator de risco para infecção do sítio cirúrgico em pacientes do HC-UFU

\begin{tabular}{ccccc}
\hline $\begin{array}{c}\text { Tempo de } \\
\text { cirurgia }\end{array}$ & \multicolumn{2}{c}{ Infecção do sítio cirúrgico } & Total & RR (IC 95\%) \\
\cline { 2 - 3 } & Sim & Não & & \\
\hline$>$ 4 horas & 46 & 680 & 726 & \\
$\leq 4$ horas & 21 & 748 & 769 & $2,3(1,4-3,8)$ \\
Total & 67 & 1428 & 1495 & \\
\hline
\end{tabular}

Fonte: Sadoyama e Gontijo Filho (2000).

Os resultados mostraram que o risco de uma infecção do sítio cirúrgico nas cirurgias demoradas ( $>4$ horas) é 2,3 vezes maior que nas cirurgias normais ( $\leq 4$ horas).

Vale ressaltar que a análise do risco relativo e seu intervalo de confiança são, em geral, concordantes com o valor de $P$ obtido nessa análise - ou seja, com a probabilidade de a diferença encontrada ter ocorrido ao acaso (o fator estudado não ser uma causa da doença ou evento em questão). Essa relação pode ser verificada no exemplo da Tabela 7.4, que demonstra os fatores de risco para infecções por Staphylococcus aureus resistentes ou sensíveis à meticilina (MRSA e MSSA, respectivamente) em pacientes internados no HC-UFU.

TABela 7.4 - Fatores de risco para infecções por Staphylococcus aureus resistentes ou sensíveis à meticilina (MRSA e MSSA, respectivamente) em pacientes internados no HC-UFU

\begin{tabular}{lccrc}
\hline FATORES DE RISCO & $\begin{array}{c}\text { MRSA (\%) } \\
\mathbf{n = 4 5}\end{array}$ & $\begin{array}{c}\text { MSSA (\%) } \\
\mathbf{n = 5 7}\end{array}$ & $\begin{array}{c}\text { Valor } \\
\mathbf{d e} \boldsymbol{P}\end{array}$ & \multirow{2}{*}{ RR (IC 95\%) } \\
\hline Sexo (M) & $31(68,9)$ & $32(56,1)$ & 0,26 & $1,73(0,71-4,27)$ \\
Restrição ao leito & $40(88,9)$ & $42(73,7)$ & 0,09 & $2,86(0,86-10,0)$ \\
Uso de antimicrobianos: & $43(95,6)$ & $46(80,7)$ & 0,05 & $5,14(0,98-35,76)$ \\
$\quad$ 1-2 antimicrobianos & $11(24,4)$ & $27(47,4)$ & 0,02 & $0,36(0,14-0,91)$ \\
$\quad \geq 3$ antimicrobianos & $31(68,9)$ & $19(33,3)$ & $<0,01$ & $4,43(1,77-11,23)$ \\
Uso de dispositivos invasivos: & $40(88,9)$ & $40(70,2)$ & 0,04 & $3,40(1,04-11,76)$ \\
$\quad$ Cateteres vasculares & $38(95,6)$ & $37(64,9)$ & 0,04 & $2,93(1,02-8,74)$ \\
$\quad$ Drenos & $7(15,6)$ & $6(10,5)$ & 0,64 & $1,57(0,43-5,82)$ \\
$\quad$ Sondas nasogástricas & $22(48,9)$ & $17(29,8)$ & 0,08 & $2,25(0,92-5,53)$ \\
$\quad$ Sondas vesicais & $19(42,2)$ & $8(14,0)$ & $<0,01$ & $4,48(1,58-13,02)$ \\
$\quad$ Tubos endotraqueais & $10(22,2)$ & $5(8,8)$ & 0,10 & $2,97(0,84-11,06)$ \\
$\quad \geq 3$ dispositivos & $18(40,0)$ & $8(14,0)$ & $<0,01$ & $4,08(1,43-11,91)$ \\
Cirurgia & $27(60,0)$ & $24(42,1)$ & 0,50 & $1,44(0,58-3,58)$ \\
\hline
\end{tabular}

$\mathrm{RR}=$ risco relativo; IC = intervalo de confiança.

Fonte: Sadoyama e Gontijo Filho (2000).

Os resultados mostraram que, quando valores de IC $95 \%$ incluem a unidade (valor 1,0 ), o valor de $P$ é maior ou igual a 0,05 - noutros termos, não existe significância estatística para o valor 
de RR. Por outro lado, quando valores de IC 95\% excluem a unidade (acima ou abaixo de 1,0), o valor de $P$ é menor que 0,05 - portanto, o valor de RR apresenta significância estatística como fator de risco ( $R R>1,0)$ ou fator de proteção $(R R<1,0)$.

Há situações que devem ser analisadas criteriosamente, por exemplo, quando a unidade se encontra no limite inferior do IC $95 \%$, o valor de $P$ pode apresentar significância $(P<0,05)$. Esse exemplo pode ser demonstrado na Tabela 7.4, onde os fatores de risco "uso de dispositivos invasivos" e "cateteres vasculares" apresentaram IC 95\% incluindo a unidade no limite inferior $[(1,04-11,76)$ e $(1,02-8,64)$, respectivamente], e os valores de $P$ foram inferiores a $0,05(P<0,04)$ em ambas as situações. Também é possível demonstrar os valores de RR e IC 95\% por meio de representação gráfica, como na Figura 7.3, que representa os dados referentes à Tabela 7.4.

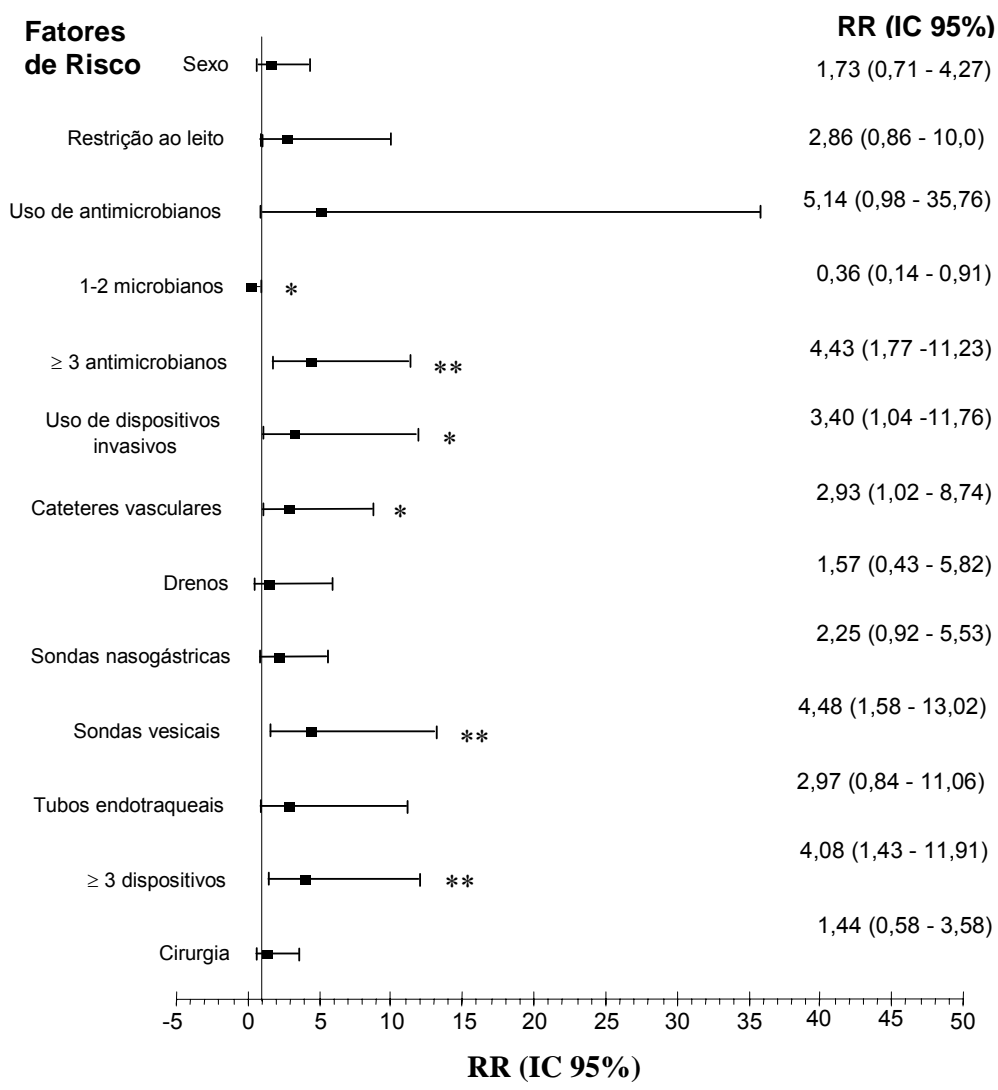

FiguRA 7.3 - Representação gráfica dos valores de risco relativo (RR) e intervalo de confiança de $95 \%$ (IC 95\%) referentes aos dados apresentados na Tabela 7.4. ${ }^{\star} P<0,05 ;{ }^{* *} P<0,001$ 


\section{CONTROLE DAS VARIÁVEIS INTERFERENTES}

Em um estudo de causalidade, é importante detectar as variáveis interferentes desconhecidas que poderão levar ao efeito de confundimento ou confusão (confounding). Ainda assim, mesmo com uma boa revisão metodológica do problema, é quase impossível conhecer todas as variáveis interferentes (exceto os estudos experimentais que possibilitam o controle de todas as variáveis). No entanto, existem vários métodos estatísticos para o controle, ao menos, das variáveis conhecidas mediante emparelhamento ou análise estratificada e multivariada.

O fator de confusão é o efeito de uma variável externa que afeta, em parte ou no todo, uma associação observada, mascarando a relação entre o fator de exposição e a doença de interesse. Ele ocorre porque só um fator de cada vez é avaliado na análise univariada. Assim, o fator de confusão é um tipo de viés que surge como conseqüência própria da análise univariada (tabelas $2 \times 2$ ).

Há dois tipos de variáveis interferentes: 1) variáveis de confundimento, que produzem confusão por causa de um desajuste na comparação entre os grupos, e 2) variáveis modificadoras de efeito, que produzem interação entre as variáveis, fazem parte do modelo causal e modificam a resposta - mesmo quando os grupos estão ajustados. Pode-se ainda encontrar um terceiro tipo de variáveis interferentes: variáveis de confundimento (grupos desajustados) e modificadoras de efeito (interação com modificação da resposta) ao mesmo tempo.

\section{1) VARIÁveis de confundimento (sem interação)}

Um exemplo clássico de variável de confundimento (sem interação) está representado na Tabela 7.5. Na análise do estado civil (variável de exposição) como fator de risco para doenças sexualmente transmissíveis (DST), observou-se que os casados apresentaram maior risco $(R R=4,0)$ de adquirir DST que os solteiros - o que leva à conclusão, enganosa, de que o casamento provoca DST (variável efeito).

TABELA 7.5 - Estado civil como fator de risco para doenças sexualmente transmissíveis (DST)

\begin{tabular}{ccccc}
\hline $\begin{array}{c}\text { Estado civil } \\
\text { (variável de } \\
\text { exposição) }\end{array}$ & \multicolumn{2}{c}{$\begin{array}{c}\text { DST } \\
\text { (variável efeito) }\end{array}$} & Total & RR (IC 95\%) \\
\hline Casado & Sim & Não & & \\
Solteiro & 100 & 400 & 500 & \\
Total & 25 & 475 & 500 & $4,0(2,6-6,1)$ \\
\hline
\end{tabular}


Ao se analisarem possíveis fatores interferentes, verificouse que os dois grupos estavam desajustados quanto à idade (variável de confundimento), como pode ser demonstrado quando as amostras foram estratificadas quanto à variável interferente (Tabelas 7.5A e $7.5 \mathrm{~B})$.

TABELA 7.5A - Amostras estratificadas quanto à idade (> 30 anos)

\begin{tabular}{ccccc}
\hline $\begin{array}{c}\text { Estado civil } \\
\text { (variável de }\end{array}$ & \multicolumn{3}{c}{ DST } \\
exposição) & Sim & Nãável efeito) & Total & RR (IC 95\%) \\
\hline Casado & 97 & 303 & 400 & \\
Solteiro & 12 & 38 & 50 & $1,0(0,6-1,7)$ \\
Total & 109 & 341 & 450 & \\
\hline
\end{tabular}

TABELA 7.5B - Amostras estratificadas quanto à idade ( $<30$ anos $)$

\begin{tabular}{|c|c|c|c|c|}
\hline \multirow{2}{*}{$\begin{array}{l}\text { Estado civil } \\
\text { (variável de } \\
\text { exposição) }\end{array}$} & \multicolumn{2}{|c|}{$\begin{array}{c}\text { DST } \\
\text { (variável efeito) }\end{array}$} & \multirow{2}{*}{ Total } & \multirow[t]{2}{*}{ RR (IC 95\%) } \\
\hline & $\overline{\text { Sim }}$ & Não & & \\
\hline Casado & 3 & 97 & 100 & \\
\hline Solteiro & 13 & 437 & 450 & $1,0(0,3-3,6)$ \\
\hline Total & 16 & 534 & 550 & \\
\hline
\end{tabular}

Nesse exemplo hipotético, a proporção de indivíduos com idade > 30 anos é muito diferente nos dois grupos analisados: $80 \%$ (400 em 500) no grupo dos casados e apenas 10\% (50 em 500) no grupo dos solteiros. Portanto, os grupos estavam desajustados no que se refere à idade (casados eram mais velhos que solteiros), o que provocou um fator de confusão ou confundimento na associação entre estado civil e DST.

Entretanto, os valores de RR calculados para as amostras estratificadas segundo a idade foram exatamente iguais $(R R=1,0)$, portanto não houve interação. Assim, a idade não modificou o efeito, ou seja, a variável interferente (idade) é de confundimento sem interação.

\section{2) Variáveis modificadoras de efeito (sem confundimento)}

Um exemplo hipotético de variável modificadora de efeito (sem confundimento) pode ser demonstrado na Tabela 7.6. Na comparação entre dois grupos de indivíduos do sexo masculino quanto à idade (variável de exposição) como fator de risco para doença cardiovascular (variável efeito), observou-se que os homens com $>40$ anos têm maior risco $(R R=4,6)$ de adquirir doença cardiovascular que aqueles com $<40$ anos. 
TABELA 7.6 - Idade como fator de risco para doença cardiovascular em homens

\begin{tabular}{ccccc}
\hline $\begin{array}{c}\text { Idade } \\
\text { (variável de }\end{array}$ & \multicolumn{2}{c}{$\begin{array}{c}\text { Doença cardiovascular } \\
\text { (variável efeito) }\end{array}$} & Total & RR (IC 95\%) \\
\cline { 2 - 5 } exposição) & Sim & Não & & \\
\hline$>\mathbf{4 0}$ anos & 69 & 681 & 750 & \\
$<\mathbf{4 0}$ anos & 15 & 735 & 750 & $4,6(2,6-8,0)$ \\
Total & 84 & 1416 & 1500 & \\
\hline
\end{tabular}

Ao se analisarem possíveis fatores interferentes, verificouse que o tabagismo poderia ser variável interferente. Assim, os dois grupos foram estratificados quanto ao hábito de fumar (Tabelas 7.6A e 7.6B), e os valores de RR, calculados para cada grupo estratificado.

TABELA 7.6A - Amostras estratificadas quanto ao tabagismo (fumantes)

\begin{tabular}{|c|c|c|c|c|}
\hline \multirow{2}{*}{$\begin{array}{c}\text { Idade } \\
\text { (variável de } \\
\text { exposição) }\end{array}$} & \multicolumn{2}{|c|}{$\begin{array}{l}\text { Doença cardiovascular } \\
\text { (variável efeito) }\end{array}$} & \multirow[t]{2}{*}{ Total } & \multirow{2}{*}{ RR (IC 95\%) } \\
\hline & Sim & Não & & \\
\hline$>40$ anos & 63 & 387 & 450 & \\
\hline$<40$ anos & 12 & 438 & 450 & $5,2(2,9-9,6)$ \\
\hline Total & 75 & 825 & 900 & \\
\hline
\end{tabular}

TABELA 7.6B - Amostras estratificadas quanto ao tabagismo (não-fumantes)

\begin{tabular}{|c|c|c|c|c|}
\hline \multirow{2}{*}{$\begin{array}{c}\text { Idade } \\
\text { (variável de } \\
\text { exposição) }\end{array}$} & \multicolumn{2}{|c|}{$\begin{array}{c}\text { Doença cardiovascular } \\
\text { (variável efeito) }\end{array}$} & \multirow[t]{2}{*}{ Total } & \multirow[t]{2}{*}{ RR (IC 95\%) } \\
\hline & $\overline{\text { Sim }}$ & Não & & \\
\hline$>40$ anos & 6 & 294 & 300 & \\
\hline$<40$ anos & 3 & 297 & 300 & $5,0(0,5-7,9)$ \\
\hline Total & 9 & 591 & 600 & \\
\hline
\end{tabular}

Pode-se observar nesse exemplo que os grupos não estão desajustados quanto à variável interferente (tabagismo): a proporção de indivíduos fumantes (450 em 750) é igual nas duas faixas etárias $(60 \%)$. Portanto, não há um fator de confundimento.

Todavia, os valores de RR calculados para as amostras estratificadas foram diferentes $(R R=5,2$ para os fumantes e $R R=$ 2,0 para os não-fumantes) - indício de que houve interação entre tabagismo e associação idade-doença cardiovascular. Assim, a variável interferente (tabagismo) não depende da idade, mas modifica a possibilidade de se ter doença cardiovascular; noutras palavras, é uma variável modificadora de efeito, mesmo sem confundimento. 
3) VARIÁVEIS DE CONFUNDIMENTO E MODIFICADORAS DE EFEITO

Um exemplo de variável de confundimento e modificadora de efeito está representado na Tabela 7.7, que mostra resultados de um estudo de coorte hipotético avaliativo dos possíveis fatores de risco para infecção hospitalar pós-parto.

TABELA 7.7 - Contaminação fecal como fator de risco para infecção hospitalar pós-parto em pacientes

\begin{tabular}{ccccc}
\hline $\begin{array}{c}\text { Contaminação } \\
\text { fecal } \\
\text { (variável de }\end{array}$ & \multicolumn{2}{c}{$\begin{array}{c}\text { Infecção } \\
\text { pós-parto } \\
\text { (variável efeito) }\end{array}$} & Total & RR (IC 95\%) \\
\cline { 2 - 5 } exposição) & Sim & Não & & 1000 \\
\hline Sim & 50 & 950 & $0,2(0,2-0,3)$ \\
Não & 200 & 800 & 1000 & \\
Total & 250 & 1750 & 2000 & \\
\hline
\end{tabular}

Embora o número de pacientes envolvidos no estudo seja grande e a análise do risco relativo tenha sido avaliada pelos cálculos do intervalo de confiança, os resultados "indicam" a contaminação fecal como fator de proteção $(R R<1,0)$ para a infecção pósparto - o que é claramente absurdo.

Ao se analisarem possíveis fatores interferentes, verificouse que os grupos estavam desajustados quanto ao tipo de parto (normal e cesariana) - como demonstram as tabelas 7.7A e 7.7B.

TABela 7.7A - Amostras estratificadas quanto ao tipo de parto (parto normal)

\begin{tabular}{ccccc}
\hline $\begin{array}{c}\text { Contaminação } \\
\text { fecal } \\
\text { (variável de }\end{array}$ & \multicolumn{2}{c}{$\begin{array}{c}\text { Infecção } \\
\text { pós-parto } \\
\text { (variável efeito) }\end{array}$} & Total & RR (IC 95\%) \\
\cline { 2 - 5 } exposição) & Sim & Não & & \\
\hline Sim & 48 & 752 & 800 & \multirow{2}{*}{ Não } \\
Não & 2 & 198 & 200 & \\
Total & 50 & 950 & 1000 & \\
\hline
\end{tabular}

TABELA 7.7B - Amostras estratificadas quanto ao tipo de parto (parto cesariana)

\begin{tabular}{cccccc}
\hline $\begin{array}{c}\text { Contaminação } \\
\text { fecal } \\
\text { (variável de }\end{array}$ & \multicolumn{2}{c}{$\begin{array}{c}\text { Infecção } \\
\text { pós-parto } \\
\text { (variável efeito) }\end{array}$} & Total & RR (IC 95\%) \\
\cline { 2 - 4 } exposição) & Sim & Não & & & \\
\hline Sim & 2 & 198 & 200 & \multirow{2}{*}{ Não } \\
Total & 198 & 602 & 800 & $0.04(0,01-0.2)$ \\
\hline
\end{tabular}

No exemplo acima, ao se analisarem os dados estratificados quanto a uma provável variável interferente (tipo de parto), os resultados mostraram que os grupos estavam desajustados em relação 
ao tipo de parto: a proporção de pacientes com parto normal difere nos dois grupos: $80 \%(800 \mathrm{em} 1.000)$ no grupo exposto à contaminação fecal e apenas $20 \%$ (200 em 1.000) no grupo não-exposto.

Por outro lado, sabe-se que a incidência de infecção hospitalar em cesarianas é superior à de partos normais. Assim, podese observar nesse exemplo que o tipo de parto provocou um fator de confusão na análise univariada do fator de risco "contaminação fecal". Na verdade, a menor incidência de infecção hospitalar nas pacientes expostas à contaminação fecal foi observada porque este fator está mais associado ao parto normal (vaginal) do que ao tipo de procedimento de maior risco de infecção (cesariana). Além disso, os valores de $R R$ calculados para as amostras estratificadas segundo a variável interferente (tipo de parto) também foram diferentes ( $R R=6,0$ para parto normal e $R R=0,04$ para cesariana), indicando que houve interação do tipo de parto com a associação contaminação fecal-infecção pós-parto. Noutras palavras, trata-se de uma variável modificadora de efeito e com confundimento.

Em termos práticos, para se verificar a existência de confundimento, deve-se analisar, em primeiro lugar, se há associação entre a variável interferente e o efeito observado e, em caso afirmativo, se os grupos estão desajustados segundo a variável interferente. Para se verificar a existência de interação entre as variáveis, devese analisar se a força da associação (medida pelo RR ou pelo OR) é diferente nas amostras estratificadas (estrato 1 e estrato 2) em relação à variável interferente.

Programas de computador - a exemplo do Epi-Info - são muito usados para controlar o efeito de tais variáveis interferentes mediante cálculos de RR não ajustado (Crude RR) e RR ajustado (Mantel-Haenszel Weighted RR) e, pela comparação entre esses valores, verificar o tipo de interferência existente:

Quando RR não ajustado = RR ajustado, não há confundimento.

Quando RR não ajustado $\neq R R$ ajustado, existe confundimento e, nesse caso, deve-se se referir apenas ao RR ajustado como medida de força da associação.

Quando RR for igual nas amostras estratificadas, não há interação.

Quando RR for diferente nas amostras estratificadas, há interação e, nesse

caso, os valores de RR para cada estrato devem ser apresentados.

Embora se evidencie o confundimento (por exemplo, RR não ajustado $=4,0$ e RR ajustado $=1,0$ ), a valorização de tal diferença não é objetiva - pois não há prova de significância estatística do confundimento - e deve ser analisada segundo sua relevância clínica.

No entanto, quando houver interação (por exemplo, $\mathrm{RR}_{\text {estrato } 1}=5,2$ e RR estrato $2=2,0$ ), deve-se verificar se essa 
diferença é estatisticamente significativa por meio da prova de MantelHaenszel Summary Chi-squared proposta no Epi-Info (para $p<$ $0,05)$.

Em resumo, as principais etapas para se identificarem e se analisarem as variáveis de confundimento e as variáveis modificadoras do efeito são:

1) listar as possíveis variáveis interferentes;

2) verificar se a associação é alterada após a estratificação das amostras segundo as variáveis interferentes;

3) se houver diferença entre o RR ajustado e RR não ajustado, há confundimento e os resultados devem conter o RR ajustado, como medida da força de associação entre a variável de exposição e o efeito observado, eliminando o efeito da variável de confundimento; 4) se houver diferenças entre RR para as amostras estratificadas, há interação (que só deve ser valorizada quando é estatisticamente significativa) e os resultados devem conter o RR de cada estrato; 5 ) se houver diferenças significativas entre RR das amostras estratificadas e entre RR ajustado e não ajustado, há confundimento e interação, devendo também ser apresentados apenas o RR de cada estrato.

\section{CONCLUSÃO}

Estudos epidemiológicos envolvendo causalidade têm grande importância para o conhecimento das causas de doenças e, por conseqüência, para uma conduta adequada nas áreas de prevenção, diagnóstico e tratamento. Os conceitos atuais de causa de doenças são mais abrangentes: consideram não só a causa única (agente etiológico), mas também causas multifatoriais de doenças, fatores de risco e efeitos. De qualquer forma, a causa deve sempre preceder a doença, e uma associação causal ou de causalidade existe quando há evidências de interação entre fatores etiológicos e de risco para o desenvolvimento da doença. Além disso, a eliminação de um desses fatores acarreta potencial redução da doença.

Fatores de risco compreendem condições necessárias, mas não suficientes, para causar uma doença particular. Podem ser genéticos, físicos, químicos, biológicos, sociais ou comportamentais. Todos podem atuar de maneira a induzir (predisponentes), favorecer (facilitadores), desencadear (desencadeantes) ou agravar (agravantes) o desenvolvimento da doença. Qualquer associação entre fatores de risco e doença para ser considerada causal deve, a princípio, excluir outras condições (acaso, viés de seleção ou aferição, fator de confusão) e preencher os seguintes critérios ou evidências epidemiológicas: relação temporal, consistência, intensidade, especifici- 
dade, relação dose-resposta, reversibilidade, plausibilidade biológica e analogia.

As associações entre causa e efeito podem ser mensuradas - as medidas mais utilizadas em epidemiologia são risco relativo (RR), risco atribuível (RA) e razão de chances (OR: odds ratio). O $\mathrm{RR}$ representa a força da associação entre fator (exposição) e doença (efeito); o RA representa o excesso de incidência da doença relacionado com a exposição; o OR representa uma medida de risco semelhante ao RR para estudos em que não é possível determinar o coeficiente de incidência (estudos seccionais ou de caso-controle). Embora esses cálculos estatísticos forneçam dados quantitativos para se avaliar a causalidade, indicam só a probabilidade de a associação observada ser causal.

Fatores epidemiológicos e biológicos devem ser analisados em conjunto para se aumentar o grau de certeza da inferência causal e, assim, se aplicarem os conhecimentos adquiridos no campo da prevenção, do diagnóstico e da terapêutica das doenças.

\section{REFERÊNCIAS}

BEAGLEHOLE, R.; BONITA, R.; KJELLSTRÖM, T. Basic epidemiology. Geneva: World Health Organization, 1994. 175p.

BERQUÓ, E. S.; SOUZA, J. M. P.; GOTLIEB, S. L. D. Bioestatística. São Paulo: Pedagógica e Universitária, 1981. 350p.

BRADFORD-HILL, A. B. The environment and disease: association or causation? Proceedings of the Royal Society of Medicine, v. 58, p. 295-300, 1965.

FLETCHER, R. H.; FLETCHER, S. W.; WAGNER, E. H. Epidemiologia clínica: elementos essenciais. 3. ed. Porto Alegre: Artes Médicas, 1996. 281p.

JORGE, M. T.; RIBEIRO, L. A. Fundamentos para o conhecimento científico: áreas de saúde. São Paulo: CLR Balieiro, 1999. 106p. KANNEL, W. B. Preventive cardiology: what should clinician be doing about it. Postgraduate Medicine, Higtstown, v. 61, n. 1, p. 74-85, 1977.

PINA, A. P. B. Uma introdução ao controle das variáveis interferentes. António Paula Brito de Pina, 2001.

ROUQUAYROL, M. Z. (Ed.). Epidemiologia e saúde. 3. ed. Rio de Janeiro: MEDSI, 1986. 416p. 
SADOYAMA, G.; GONTIJO FILHO, P. P. Risk factors for methicillin resistant and sensitive Staphylococcus aureus infection in a Brazilian university hospital. Brazilian Journal of Infectious Diseases, Salvador, v. 4, p. 135-143, 2000.

SWINSCOW, T. D. V. Statistics at Square One. 7th ed. London: British Medical Association, 1980. 86p. 
8.

\title{
MÉTODOS DE ANÁLISE EM ESTUDOS SOBRE DIAGNÓSTICO
}

\author{
Mônica Camargo Sopelete
}

\section{INTRODUÇÃO}

Neste capítulo, serão abordados temas relativos à validação e análise de testes laboratoriais para fins de diagnóstico ou de pesquisa. Definições como as de sensibilidade, especificidade e valores preditivos serão apresentadas, e também os respectivos cálculos e fatores que as influenciam diretamente. A seguir, serão abordados alguns conceitos técnicos, tais como ponto de corte e curva ROC - utilizados em medicina laboratorial. Definições e exemplos aqui apresentados terão o objetivo de introduzir o leitor na análise cuidadosa da eficácia dos métodos empregados em diagnóstico laboratorial e permitir uma análise criteriosa dos resultados obtidos.

\section{SENSIBILIDADE E ESPECIFICIDADE}

Quando o resultado de um exame laboratorial chega às mãos do médico, este deve confirmar ou rejeitar a hipótese diagnóstica formulada por ele. Assim, o médico necessita de exames que indiquem, com precisão e exatidão, a presença ou a ausência de fatores relacionados à doença investigada. A confiança no teste laboratorial indicado em revelar um resultado real (positivo/negativo) é importante para maior certeza na hipótese diagnóstica.

Um procedimento laboratorial dicotômico perfeito (onde são possíveis somente dois resultados: positivo ou negativo) identifica como positivas as pessoas que, de fato, são doentes e como negativas as pessoas sadias em relação à doença investigada. Admitindose que um laboratório trabalhe em condições ótimas, com reagentes de boa qualidade e dentro dos prazos de validade, técnicas adequadas, pessoal capacitado, equipamentos calibrados e controle de qualidade adequado, prevê-se então que os desvios de um resultado real são conseqüência direta da "qualidade intrínseca do teste". Logo, conceitos como sensibilidade, especificidade e valor preditivo 
de um teste foram criados e definidos para se mensurarem melhor o grau de confiança e a qualidade intrínseca do teste laboratorial.

Conforme definido por Galen e Gambino (1975), sensibilidade é "a positividade na doença", e especificidade é a "negatividade na saúde". Assim:

sensibilidade é a capacidade de um teste ser positivo

(detectar os indivíduos doentes)

dentre aqueles efetivamente doentes.

especificidade é a capacidade de um teste ser negativo (detectar os indivíduos sadios)

dentre aqueles efetivamente livres da doença.

Para se verificar a validade destes dois parâmetros em um novo teste, comparam-se seus resultados com aqueles determinados por técnicas de diagnóstico de certeza (ou não duvidosas) também conhecidas como padrão ouro ou gold standard. Um bom exemplo de teste padrão ouro é um teste que permite determinar o agente etiológico, tais como métodos de diagnóstico parasitológico em que se observa a presença de ovos ou parasitos em amostras de fezes. Sinais patognomônicos de uma doença podem também ser usados como diagnóstico de certeza de um teste diagnóstico.

Entretanto, em algumas patologias é difícil estabelecer um teste padrão ouro. Muitas vezes, a opção é pelos testes mais baratos, de menor complexidade ou menor tempo de execução; em outros casos, algumas condições clínicas não apresentam critérios de diagnóstico completamente confiáveis, o que dificulta a caracterização de um teste padrão ouro. Assim, deve-se ter em mente que esse teste pode não ser perfeito, mas pode ser o "melhor" à disposição.

Uma vez estabelecidos os valores de sensibilidade e de especificidade do teste laboratorial numa amostra de indivíduos, eles podem ser estendidos à população em geral — da qual a amostra representa uma parcela. Porém, não se trata mais aqui de investigar "a positividade na doença" nem a "negatividade na saúde"; mas sim, dentre o total de positivos, determinar quantos são efetivamente doentes e, do total de negativos, quantos são efetivamente saudáveis.

Para se determinar a confiança de um novo teste diagnóstico, no que se refere à detecção dos verdadeiros positivos e dos verdadeiros negativos, avaliam-se indivíduos doentes e sadios e seus respectivos resultados frente ao teste padrão ouro. Por tradição, os dados são organizados conforme a tabela de contingência representada na Figura 8.1: 


\begin{tabular}{|c|c|c|c|}
\hline \multirow{2}{*}{ Novo teste } & \multicolumn{2}{|c|}{ Doença (ou teste padrão ouro) } & \multirow{2}{*}{ Total } \\
\hline & Presente & Ausente & \\
\hline Positivo & $\begin{array}{c}\text { Verdadeiros } \\
\text { positivos } \\
\text { (a) }\end{array}$ & $\begin{array}{c}\text { Falsos } \\
\text { positivos } \\
\text { (b) }\end{array}$ & $\begin{array}{c}\text { Total de } \\
\text { positivos } \\
(\mathbf{a}+\mathbf{b})\end{array}$ \\
\hline Negativo & $\begin{array}{l}\text { Falsos } \\
\text { negativos } \\
\text { (c) }\end{array}$ & $\begin{array}{l}\text { Verdadeiros } \\
\text { negativos } \\
\text { (d) }\end{array}$ & $\begin{array}{l}\text { Total de } \\
\text { negativos } \\
(\mathbf{c}+\mathbf{d})\end{array}$ \\
\hline Total & $\begin{array}{l}\text { Total de } \\
\text { doentes } \\
(\mathbf{a}+\mathbf{c})\end{array}$ & $\begin{array}{l}\text { Total de } \\
\text { sadios } \\
(\mathbf{b}+\mathbf{d})\end{array}$ & $\begin{array}{c}\text { Total } \\
(a+b+c+d)\end{array}$ \\
\hline
\end{tabular}

FIGURA 8.1 - Representação esquemática de uma tabela de contingência $2 \times 2$ demonstrando os resultados de um novo teste laboratorial frente aos resultados de um teste padrão ouro (doença)

Assim, observam-se quatro possíveis tipos de resultados de acordo com a presença ou não da doença investigada: 1) verdadeiros positivos - indivíduos que têm a doença e nos quais o teste foi positivo; 2) verdadeiros negativos - indivíduos que não têm a doença e nos quais o teste foi negativo; 3) falsos negativos - indivíduos que têm a doença e nos quais o teste foi negativo; e 4) falsos positivos - indivíduos que não têm a doença e nos quais o teste foi positivo. Na tabela, observa-se que o total de doentes é dado pela somatória dos verdadeiros positivos e falsos negativos, e o total de sadios, pela somatória dos falsos positivos e verdadeiros negativos.

Assim:

Sensibilidade $=\frac{\text { verdadeiros positivos }(a)}{\text { verdadeiros positivos }(a)+\text { falsos negativos }(c)} \times 100$
Especificidade $=\frac{\text { verdadeiros negativos }(d)}{\text { falsos positivos }(b)+\text { verdadeiros negativos }(d)} \times 100$

Posto isso, um teste com $100 \%$ de sensibilidade e $100 \%$ de especificidade produziria dois resultados mutuamente exclusivos: resultado positivo em indivíduos doentes e resultado negativo em indivíduos saudáveis; resultados discordantes como falsos positivos e falsos negativos não ocorreriam.

Entretanto, na prática, testes de alta sensibilidade e especificidade não atingem o valor de $100 \%$. Então, o que significa um teste com $95 \%$ de sensibilidade e $93 \%$ de especificidade? Significa que um teste com $95 \%$ de sensibilidade detecta como positivo 95 indivíduos em 100 indivíduos doentes, ou seja, não confirma a hipótese diagnóstica em 5 indivíduos doentes que seriam dados como 
saudáveis pelo teste. Da mesma forma, um teste com $93 \%$ de especificidade fornece 93 resultados negativos em 100 indivíduos saudáveis, mas detecta 7 como doentes dentre os saudáveis. Vale dizer que a análise da sensibilidade e da especificidade é feita na vertical na tabela de contingência. A primeira coluna se relaciona com a sensibilidade; a segunda, com a especificidade.

\section{PROBABILIDADE DO PRÉ-TESTE OU PROBABILIDADE DE OCORRÊNCIA}

Muitas vezes torna-se necessário determinar a probabilidade de ocorrência de uma dada doença na população antes de se executar o teste diagnóstico. Como exemplo, considere-se que uma enfermidade com $10 \%$ de prevalência se traduziria em uma probabilidade de $10 \%$ de resultados confirmatórios. Logo, a probabilidade de ocorrência está intimamente associada com a prevalência da doença em questão.

Nesse sentido, probabilidade do pré-teste é a estimativa da probabilidade de doença (resultado positivo) antes mesmo de o teste ser realizado. Em uma população definida de pacientes, tal probabilidade é igual à prevalência da doença nessa população, e seu cálculo pode ser assim determinado:

$$
\text { probabilidade do pré }- \text { teste }=\frac{\text { total de doentes }(a+c)}{\text { população total analisada }(a+b+c+d)}
$$

\section{VALOR PREDITIVO POSITIVO E VALOR PREDITIVO NEGATIVO}

Para confirmação de uma hipótese diagnóstica e validação de um procedimento laboratorial, seriam suficientes os testes diagnósticos de alta sensibilidade e especificidade? Validar um procedimento significa estabelecer um valor de predição ou valor preditivo, isto é, verificar a capacidade de um dado teste de identificar corretamente o verdadeiro status diagnóstico da doença em questão nos indivíduos analisados.

Valor preditivo positivo (VP+) de um teste laboratorial é a probabilidade de existir doença quando o resultado do teste for positivo.

Valor preditivo negativo (VP-) de um teste laboratorial é a probabilidade de não existir doença quando o teste for negativo. 
Seus cálculos podem ser assim definidos:

$$
\begin{aligned}
& V P+=\frac{\text { verdadeiros positivos }(a)}{\text { verdadeiros positivos }(a)+\text { falsos positivos }(b)} \times 100 \\
& V P-=\frac{\text { verdadeiros negativos }(d)}{\text { falsos negativos }(c)+\text { verdadeiros negativos }(d)} \times 100
\end{aligned}
$$

Caso um teste laboratorial não detecte nenhum indivíduo falso positivo $(b=0)$ - logo, todos os indivíduos testados apresentam a doença investigada -, então o valor preditivo positivo do teste será de $100 \%$, pois $\mathrm{a} \div \mathrm{a}=1$. O mesmo raciocínio vale para $\mathrm{o}$ valor preditivo negativo.

Contudo, valores preditivos de $100 \%$ são eventos de ocorrência bastante rara em exames laboratoriais, pois quase sempre existe algum grau de sobreposição entre resultados de indivíduos normais e indivíduos acometidos por uma doença específica. Para definirem quais valores corresponderiam a resultados positivos e quais a resultados negativos, em geral os testes laboratoriais apresentam valores de corte (ou pontos de corte, ou ainda, em inglês, cut off). Métodos empregados na definição de um ponto de corte em um dado teste laboratorial serão descritos mais adiante neste mesmo capítulo.

O valor preditivo de um teste (seja este positivo ou negativo) depende da sensibilidade e da especificidade do teste diagnóstico, assim como da prevalência da doença na população em geral. Voltando ao exemplo de um teste laboratorial com VP+ igual a $100 \%$, numa população em que todos os indivíduos apresentam a doença investigada, todos os resultados positivos serão verdadeiramente positivos; logo, não haverá falsos positivos. No entanto, quando esse mesmo teste é aplicado em uma população em que nenhum indivíduo apresenta a doença em questão, qualquer resultado positivo será, sem dúvida, falso positivo.

Dessa forma, nessa população específica, com prevalência de $0 \%$ da doença, o VP+ não será de $100 \%$, e sim de $0 \%$. Concluise que a prevalência da doença influencia o VP+ por ter influência direta sobre as taxas de verdadeiros positivos e falsos positivos e, por analogia, o VP- por influenciar as taxas de verdadeiros negativos e falsos negativos.

Outro exemplo - relatado por Jorge e Ribeiro (1999), mais detalhado e nem tão extremo - esclarece melhor essa relação entre valores preditivos e sensibilidade, especificidade e prevalência. Considere-se que um teste laboratorial para detectar a infecção 
pelo vírus da imunodeficiência humana (HIV) apresenta sensibilidade de $90 \%$ e especificidade de $80 \%$. Qual seria o VP+ desse teste em dois pacientes oriundos das populações $A$ e $B$, cuja prevalência de tal infecção fosse de $60 \%$ e $1 \%$, respectivamente? Em resumo:

Teste laboratorial para diagnóstico de HIV $\Rightarrow$ Sensibilidade $=90 \%$ Especificidade $=80 \%$

$\begin{aligned} \text { Prevalência de HIV } \Rightarrow \quad \begin{array}{l}\text { População } A \\ \text { População } B=60 \%\end{array} & =1 \%\end{aligned}$

Na população A, em cada 1.000 indivíduos, 600 estão infectados, e 400 não. Se o teste apresenta $90 \%$ de sensibilidade, isso significa que, dos 600 infectados, $90 \%$ serão positivos (540 verdadeiros positivos) e $10 \%$ serão negativos (60 falsos negativos). Se o teste apresenta $80 \%$ de especificidade, dos 400 não-infectados, 320 serão verdadeiros negativos e 80 serão falsos positivos. Portanto, quanto à população $A$ (Figura 8.2) tem-se:

\section{População A}

\begin{tabular}{cccc}
\hline Novo teste & \multicolumn{2}{c}{ Doença (ou teste padrão ouro) } & Total \\
\cline { 2 - 4 } & Presente & Ausente & $\mathbf{8 0}$ \\
Positivo & $\mathbf{5 4 0}$ & $(\mathrm{b})$ & $\mathbf{6 2 0}$ \\
Negativo & $(\mathrm{a})$ & $\mathbf{3 2 0}$ & $(\mathrm{a}+\mathrm{b})$ \\
Total & $(\mathrm{c})$ & $(\mathrm{d})$ & $\mathbf{3 8 0}$ \\
& $\mathbf{6 0 0}$ & $\mathbf{4 0 0}$ & $(\mathrm{c}+\mathrm{d})$ \\
& $(\mathrm{a}+\mathrm{c})$ & $(\mathrm{b}+\mathrm{d})$ & $(\mathrm{a}+\mathrm{b}+\mathrm{c}+\mathrm{d})$ \\
\hline & $V P+=\frac{540}{540+80}=\frac{540}{620}=87,1 \%$ & \\
& $V P-=\frac{320}{60+320}=\frac{320}{380}=84,1 \%$ &
\end{tabular}

FiguRA 8.2 - Representação esquemática de uma tabela de contingência $2 \times 2$ e cálculos de valores preditivos (VP+/VP-) para uma população hipotética $A$ (prevalência de HIV $=60 \%$ ). a: verdadeiros positivos; b: falsos positivos; c: falsos negativos; d: verdadeiros negativos

Logo, VP+ $=87,1 \%$ significa que a probabilidade de o indivíduo da população A com teste positivo estar infectado pelo HIV é de $87,1 \%$.

Já na população B (Figura 8.3), com prevalência de HIV = 1\%: 10 em cada 1.000 indivíduos estão infectados, e 990 não. Se 
o teste apresenta $90 \%$ de sensibilidade, isso significa que, dos dez infectados, $90 \%$ serão positivos (nove verdadeiros positivos) e 10\% serão negativos (um falso negativo). Se o teste apresenta $80 \%$ de especificidade, dos 990 não-infectados, 792 serão verdadeiros negativos e 198 serão falsos positivos. Portanto, quanto à população B (Figura 8.3) tem-se:

\section{População B}

\begin{tabular}{cccc}
\hline Novo teste & \multicolumn{2}{c}{ Doença (ou teste padrão ouro) } & Total \\
\cline { 2 - 4 } & Presente & Ausente & $\mathbf{1 9 8}$ \\
\hline Positivo & $\mathbf{9}$ & $(\mathrm{b})$ & $\mathbf{2 0 7}$ \\
Negativo & $\mathbf{1})$ & $\mathbf{7 9 2}$ & $(\mathrm{a}+\mathrm{b})$ \\
Total & $(\mathrm{c})$ & $(\mathrm{d})$ & $\mathbf{7 9 3}$ \\
& $\mathbf{1 0}$ & $\mathbf{9 9 0}+\mathrm{d})$ \\
& $(\mathrm{a}+\mathrm{c})$ & $(\mathrm{b}+\mathrm{d})$ & $(\mathrm{a}+\mathrm{b}+\mathrm{c}+\mathrm{d})$ \\
& $V P+=\frac{9}{9+198}=\frac{9}{207}=4,3 \%$ & \\
& $V P-=\frac{792}{1+792}=\frac{792}{793}=99,9 \%$ &
\end{tabular}

FIGURA 8.3 - Representação esquemática de uma tabela de contingência $2 \times 2$ e cálculos de valores preditivos (VP+/VP-) para uma população hipotética $B$ (prevalência de HIV = 1\%). a: verdadeiros positivos; b: falsos positivos; c: falsos negativos; d: verdadeiros negativos

Assim, VP+ $=4,3 \%$ significa que a probabilidade de o indivíduo da população $B$ com teste positivo estar realmente infectado com o HIV é de 4,3\%. O mesmo raciocínio vale para o cálculo do VP- do teste, de $84,2 \%$ e de $99,9 \%$ para os indivíduos da população $A$ e $B$, respectivamente; nesse caso, isso significa a probabilidade de não estarem realmente infectados porque têm teste negativo.

Nesse sentido, um mesmo teste com determinada sensibilidade e especificidade, mas empregado em populações com diferentes prevalências - como essas exemplificadas acima - apresentará resultados diferentes de valores preditivos. Logo, quanto maior for a prevalência da doença (população A), mais provável será a correspondência de um resultado positivo do teste à doença; ao mesmo tempo, quanto menor for a prevalência da doença (população B), mais provável será a correspondência de um resultado negativo do teste à ausência de doença. Uma vez ciente das prevalências tão distintas das populações $A$ e $B$, o médico terá mais confiança para definir como positivo o indivíduo da população $\mathrm{A}(\mathrm{VP}+=87,1 \%)$ em relação ao da população $\mathrm{B}(\mathrm{VP}+=4,3 \%)$. 
Após todos esses cálculos, para que não reste dúvida sobre a utilidade dos valores preditivos na confiança do teste e para que o médico - com base no teste laboratorial - defina melhor o diagnóstico de seu paciente, só agora revela-se que o paciente da população $A$ é um usuário de drogas injetáveis e que o da população $B$ é uma freira.

É importante ressaltar que a análise dos valores preditivos é feita na horizontal na tabela de contingência, em que a primeira linha se relaciona com o valor preditivo positivo e a segunda, com o valor preditivo negativo.

\section{MEDIDAS DA EFICIÊNCIA DE UM TESTE LABORATORIAL}

ÍNDice de Youden (J)

O índice de Youden (J), expresso por um valor numérico apenas, é uma das maneiras de se calcular a eficiência de um teste. Definido por Youden (1950), o cálculo pode ser feito pelas seguintes fórmulas:

$$
J=\left[\frac{a}{a+c}+\frac{d}{b+d}\right]-1 \quad \text { ou } \quad J=(\text { Sensibilidade })+(\text { Especificidade })-1
$$

onde:

$\mathrm{a}=$ verdadeiros positivos;

$c=$ falsos negativos;

$\mathrm{b}=$ falsos positivos;

$d=$ verdadeiros negativos;

$\mathrm{a}+\mathrm{c}=$ indivíduos com a doença;

$b+d=$ indivíduos sem a doença.

Os valores do índice variam de $-1 \mathrm{a}+1$. Para um teste perfeito, é +1 , sendo que valores intermediários podem ser obtidos. Sua grande limitação, entretanto, é não permitir a identificação de problemas de sensibilidade e especificidade do teste.

Em um exemplo hipotético, na Figura 8.4 tem-se: 


\begin{tabular}{cccc}
\hline Novo teste & \multicolumn{2}{c}{ Teste padrão ouro } & Total \\
\cline { 2 - 4 } & Presente & Ausente & 2 \\
Positivo & $\mathbf{1 9}$ & $(\mathrm{b})$ & $\mathbf{2 1}$ \\
Negativo & $\mathbf{9}$ & $\mathbf{7 5}$ & $(\mathrm{a}+\mathrm{b})$ \\
& $(\mathrm{c})$ & $(\mathrm{d})$ & $\mathbf{8 4}$ \\
Total & $\mathbf{2 8}$ & $\mathbf{7 7}$ & $(\mathrm{c}+\mathrm{d})$ \\
& $(\mathrm{a}+\mathrm{c})$ & $(\mathrm{b}+\mathrm{d})$ & $(\mathrm{a}+\mathrm{b}+\mathrm{c}+\mathrm{d})$ \\
\hline \multirow{2}{*}{} & $J=\left[\frac{19}{19+9}+\frac{75}{2+75}\right]-1=0,65$ &
\end{tabular}

Figura 8.4 - Representação esquemática de uma tabela de contingência $2 \times 2$ e cálculo do índice de Youden (J), comparando-se em uma doença hipotética a eficiência no diagnóstico de um novo teste laboratorial com um teste padrão ouro. a: verdadeiros positivos; $b$ : falsos positivos; $c$ : falsos negativos; $d$ : verdadeiros negativos

Í́NICE de VAlidade (Acurácia) e KapPa

A Acurácia pode ser empregada, de uma maneira geral, para mensurar a eficiência de um dado teste e possibilitar, assim, "medir" os achados verdadeiros (verdadeiros positivos e verdadeiros negativos) - alvo de todo teste diagnóstico. A Acurácia expressa, em número (ou proporção), os resultados classificados corretamente pelo teste diagnóstico.

Entretanto, ela pode ainda ser empregada na comparação entre testes diagnósticos. Assim, esse índice é a probabilidade de concordância de um mesmo resultado entre um novo teste e o teste padrão ouro. $O$ índice de validade é expresso em porcentagem, calculado como segue:

$$
\text { Índice de validade }=\text { Acurácia }=\frac{a+d}{a+b+c+d}
$$

Usando-se o mesmo exemplo acima (Figura 8.4) e aplicandose a fórmula:

$$
\text { Índice de validade }=\frac{19+75}{19+2+9+75}=0,895
$$

O valor 0,895 do índice de validade significa que $89,5 \%$ dos casos foram diagnosticados corretamente pelo novo teste em relação ao teste padrão ouro. Mas esse índice não é suficiente para responder se o novo teste é ferramenta útil em diagnóstico. Nesse caso, o índice Kappa ( $\kappa$ ) responde melhor.

Modificação do índice de validade, o índice Kappa compara 
a concordância obtida com a esperada pela chance. Para se calculálo, o índice de validade encontrado é comparado com o índice de validade esperado, quando o teste padrão ouro e o novo teste forem realizados de forma independente:

$$
\kappa=\frac{\text { Índice de validade encontrado }- \text { Índice de validade esperado }}{1-\text { Índice de validade esperado }}
$$

O valor 0,895 do índice de validade obtido no exemplo acima é o índice de validade encontrado. O passo seguinte consiste em calcular a probabilidade de um resultado positivo em ambos os testes e em refazer a tabela de contingência.

Retomando esse exemplo (Figura 8.4), 26,8\% (28/105) são resultados positivos pelo teste padrão ouro e $20 \%$ (21/105) são resultados positivos pelo novo teste. Logo, a probabilidade de um resultado ser positivo para ambos os testes será de $0,268 \times 0,20=$ 0,0534 . Aplicando-se essa probabilidade na população em estudo (105 casos), tem-se: $0,0534 \times 105=5,6$ casos como verdadeiros positivos.

Nesse caso, a tabela de contingência ficaria assim (Figura 8.5):

\begin{tabular}{cccc}
\hline \multirow{2}{*}{ Novo teste } & \multicolumn{2}{c}{ Teste padrão ouro } & \multirow{2}{*}{ Total } \\
\cline { 2 - 4 } & Presente & Ausente & \\
\hline Positivo & 5,6 & 15,4 & 21 \\
& $(a)$ & $(b)$ & $(a+b)$ \\
Negativo & 22,4 & 61,6 & 84 \\
& $(c)$ & $(d)$ & $(c+d)$ \\
Total & 28 & 77 & 105 \\
& $(a+c)$ & $(b+d)$ & $(a+b+c+d)$ \\
\hline
\end{tabular}

FIGURA 8.5 - Representação esquemática de uma tabela de contingência $2 \times 2$ demonstrando os resultados de um novo teste laboratorial com um teste padrão ouro no diagnóstico de uma doença hipotética. a: verdadeiros positivos; b: falsos positivos; c: falsos negativos; d: verdadeiros negativos

onde:

$a+d(5,6+61,6)=67,2-$ que representa o número de resultados concordantes para ambos os testes - , e o índice de validade esperado será de $(67,2 / 105) \times 100=64 \%$.

Como foi dito, o índice Kappa compara o índice de validade encontrado $(0,895)$ com o índice de validade esperado $(0,64)$ :

$$
\kappa=\frac{0,895-0,64}{1-0,64}=0,71
$$

Os valores do índice Kappa permitem as interpretações a seguir, de acordo com os graus de concordância entre os testes. 
Pobre: $\kappa<0,20$; regular: $0,20<\kappa<0,40$; moderada: $0,40<\kappa<$ 0,60; boa: $0,60<\kappa<0,80$; excelente: $0,80<\kappa<1,0$.

Valores negativos de índice Kappa indicam problemas na aplicação do teste laboratorial, que deve então ser revista.

\section{RAZÃo DE PROBABILIDADES}

Razão de probabilidades (RP) — ou likelihood ratios (LR) é um método alternativo para se avaliar a "performance" ou a qualidade de um teste diagnóstico para dada doença, ou mesmo a validade de um sinal ou sintoma no diagnóstico de uma doença específica. Sumariza o mesmo tipo de informação que a sensibilidade e especificidade e representa a probabilidade da doença após um teste positivo (RP+) ou negativo (RP-). Em outras palavras, $\mathrm{RP}+$ indica o aumento da probabilidade da doença se o teste é positivo, e RP- indica o decréscimo da probabilidade da doença se o teste é negativo. As fórmulas para o cálculo das razões de probabilidades são:

$$
\begin{aligned}
& R P+=\frac{\text { probabilidade de indivíduos com a doença terem testes positivos }}{\text { probabilidade de indivíduos sem a doença terem testes positivos }} \\
& R P-=\frac{\text { probabilidade de indivíduos com a doença terem testes negativos }}{\text { probabilidade de indivíduos sem a doença terem testes negativos }} \\
& \qquad
\end{aligned}
$$

Razões de probabilidades podem ser expressas, também, em relação à sensibilidade e especificidade:

$$
R P+=\frac{\text { Sensibilidade }}{1-\text { Especificidade }}
$$

$$
R P-=\frac{1-\text { Sensibilidade }}{\text { Especificidade }}
$$

Em geral, $\mathrm{RP}+$ traduz a chance de um indivíduo com resultado positivo ter realmente a doença investigada, e RP- traduz a chance de um indivíduo com resultado negativo ter realmente a doença. Para interpretar os valores de RP segundo sua definição, convém lembrar que RP > 1 indica aumento da probabilidade de a doença investigada existir, e valores de RP $<1$, um decréscimo da probabilidade de a doença existir. Os valores de RP permitem as seguintes interpretações:

- grande e conclusivo aumento na probabilidade da doença: $\mathrm{RP}>$ 10;

- moderado aumento na probabilidade da doença: $5<\mathrm{RP}<10$; 
- pequeno aumento na probabilidade da doença: $2<\mathrm{RP}<5$;

- aumento mínimo na probabilidade da doença: $1<\mathrm{RP}<2$;

- não há mudança na probabilidade da doença: $R P=1$;

- decréscimo mínimo na probabilidade da doença: $0,5<\mathrm{RP}$ $<1,0$;

- pequeno decréscimo na probabilidade da doença: $0,2<\mathrm{RP}$ $<0,5$;

- moderado decréscimo na probabilidade da doença: $0,1<$ $\mathrm{RP}<0,2$;

- grande e conclusivo decréscimo na probabilidade da doença: $\mathrm{RP}<0,1$.

\section{TESTE DIAGNÓSTICO: INTERPRETAÇÃO CLÍNICA E LABORA- TORIAL DOS RESULTADOS}

Define-se como teste diagnóstico o procedimento - laboratorial ou não - que leve à indicação de que o indivíduo analisado tem determinada doença. A escolha do melhor teste diagnóstico para a doença analisada será baseada nos seus valores preditivos e em outras características como ser rápido, conveniente e/ou de custo não elevado. Após conhecer as características clínicas e epidemiológicas e o resultado do teste diagnóstico de seu paciente, o médico pode chegar a diferentes conclusões:

Conclusão 1: Em um paciente assintomático e não pertencente a qualquer grupo de risco para a doença investigada:

- Um resultado positivo será possivelmente falso e não representa infecção e/ou doença;

- Um resultado negativo afasta a possibilidade de infecção e/ ou doença.

Conclusão 2: Em um paciente com sintomatologia clínica específica ou com alta probabilidade epidemiológica:

- Um resultado positivo confirma a infecção e/ou doença;

- Um resultado negativo tem grande probabilidade de estar errado.

Em muitos casos, recomenda-se que o teste laboratorial seja repetido e confirmado para o paciente ser definido como doente, exceto nos casos em que haja forte suspeita clínica e epidemiológica de infecção ou doença. Nos indivíduos assintomáticos e não expostos a fatores de risco específicos para a doença analisada, é recomendável dois resultados positivos de um mesmo teste (repetição) ou dois resultados positivos em diferentes testes para se defini-los como doentes. Da mesma forma, um resultado negativo não significa ausência de infecção, pois, além do valor preditivo 
negativo do teste, outros fatores podem concorrer para a nãoreatividade. Em sorologia, por exemplo, o principal deles é a janela imunológica definida como o intervalo de tempo entre o início da infecção e a possibilidade de detecção de anticorpos específicos.

Vale a pena ressaltar que testes de triagem, rastreamento ou screening não são considerados testes diagnósticos, porque, conforme sua definição, permitem a identificação da infecção/doença em indivíduos aparentemente saudáveis. Em geral, a triagem permite só a separação dos indivíduos que talvez tenham a infecção/ doença analisada daqueles que provavelmente não a tenham nesse caso, os primeiros devem ser submetidos a uma avaliação médica para elucidação do diagnóstico.

Testes ou programas de triagem podem ter como objetivos gerais desde fazer parte de um estudo epidemiológico, no intuito de analisar a prevalência de uma dada doença, até mesmo detectar indivíduos susceptíveis, assintomáticos e portadores de uma infecção e/ou doença visando imunizá-los, realizar tratamento preventivo e evitar a transmissão da doença em questão. Para tanto, os testes empregados devem ser precisos, confiáveis e, em alguns casos, rápidos, baratos, de fácil execução e inócuos a quem os manipula.

\section{Ponto de Corte e Curva Roc}

Em geral, um teste diagnóstico apresenta dois tipos de resultados (positivo ou negativo). Nas biopsias, tem-se a presença ou ausência do fator analisado para aquela investigação; nesse caso, a presença está relacionada com resultado positivo, e a ausência, com resultado negativo. Nesses casos, essas variáveis são denominadas categóricas.

No caso de variáveis contínuas, em que números representam valores positivos ou negativos, para se definir um valor a partir do qual o resultado é considerado positivo, faz-se necessário definir o nível de alteração da variável contínua que positivará o teste. Essa escolha envolve tomada de decisão referente a aumentar a sensibilidade à custa de redução da especificidade e vice-versa. Assim, a escolha de um valor permitirá essa definição.

O ponto de corte - ou cut off - de determinado teste nada mais é que um valor numérico pelo qual se pode definir um resultado como positivo, negativo ou, ainda, como duvidoso/ indeterminado.

A sensibilidade e especificidade de um teste diagnóstico e, por conseqüência, seus valores preditivos dependem não só da "qualidade" do teste, mas também da definição do que constitui um teste "anormal" ou negativo. Para facilidade de interpretação, 
em geral determina-se o valor mais alto da normalidade da doença em estudo.

Entretanto, outros fatores devem ser analisados.

1. Se a principal preocupação é evitar resultados falsos positivos (o resultado do teste pode indicar um tratamento ou intervenção arriscada para o paciente), então o ponto de corte deve objetivar o máximo de especificidade - por exemplo: sorologia para toxoplasmose congênita.

2. Se a preocupação maior é evitar resultados falsos negativos (o resultado do teste em suspeito de AIDS), então o ponto de corte deve objetivar o máximo de sensibilidade - por exemplo: triagem sorológica em bancos de sangue.

A curva ROC (Receiver Operating Characteristic curve) é a melhor maneira para se estabelecer o ponto de corte, por se basear nos melhores valores de sensibilidade e especificidade do teste diagnóstico - obtidos com diferentes pontos de corte possíveis.

Seu principal objetivo é ajudar a decidir onde será a linha divisória (ponto de corte) entre um resultado "normal" e um "anormal". É constituída de análise gráfica da sensibilidade em função da proporção dos resultados falsos positivos, ou seja, a taxa de verdadeiros positivos em relação à taxa de falsos positivos. O gráfico é construído com base em uma tabela onde cada ponto da curva representa valores de [sensibilidade] versus [1 - especificidade] para os vários possíveis pontos de corte do teste diagnóstico (critérios de positividade).

Na construção da tabela que originará a curva ROC clássica, para cada valor possível de ponto de corte são colocados os valores de sensibilidade de forma a compor o eixo $\mathrm{Y}$, e os valores de [1 - especificidade] vão compor o eixo $X$. Entretanto, devido à forma de construção do gráfico ( $\mathrm{X}$ versus $\mathrm{Y}$ ), os valores do ponto de corte não são demonstrados graficamente e, para se acessálos, é preciso recorrer à tabela que originou o gráfico.

Esse problema foi contornado com o desenvolvimento de uma adaptação da curva ROC clássica, a TG-ROC (Two Graph Receiver Operating Characteristic curve), em que valores de sensibilidade e especificidade geram duas curvas em relação aos possíveis valores de ponto de corte do teste diagnóstico; com isso, permitese ao leitor observar graficamente a dinâmica dos valores de sensibilidade/especificidade e os valores de ponto de corte definidos pelos pesquisadores para aquele teste diagnóstico. Além de descrever valores de sensibilidade e especificidade, a TG-ROC possibilita investigar a eficiência, o índice de Youden $(\mathrm{J})$ e a razão de probabilidades (RP+ e/ou RP-) do novo teste em relação ao padrão ouro. 
Curvas ROC podem ser executadas em programas computacionais mais elaborados como MedCalc, SAS, STATA, GraphROC, PRISM 4.0 e em programas de domínio público como CLABROCW, LABROC1, AUROC, TG-ROC e outros. Em termos de facilidade operacional, também podem ser executados no Microsoft Excel em suas várias versões.

É comum sua execução pressupor os seguintes passos:

1) definir possíveis valores de ponto de corte em que, no caso de variáveis discretas, cada observação gera um ponto de corte; no caso de variáveis contínuas, cada ponto pode ser arbitrariamente definido de acordo com intervalos numéricos pré-definidos (a cada 10, 100 ou outro intervalo);

2) para cada critério de ponto de corte definido, calcular sensibilidade e especificidade obtidas com o novo teste que está sob avaliação, em comparação com um teste padrão ouro;

3) montar uma tabela $X Y$ em que, no $X$, serão listados valores de [1- especificidade] e, no $Y$, valores de sensibilidade;

4) construir um gráfico de dispersão $(X Y)$ com pontos de dados conectados por linhas suaves e com marcadores.

A curva ROC clássica (Figura 8.6) demonstra vários aspectos relacionados com a análise de testes diagnósticos:

1. quanto mais próxima a inflexão da curva ficar da ponta do quadrante superior esquerdo, mais eficiente é o teste;

2. quanto mais próxima a inflexão da curva ficar da reta diagonal que divide o gráfico em $45^{\circ}$, menos eficiente é o teste;

3. o slope da tangente da curva ROC representa a razão de probabilidade;

4. a área sob a curva permite avaliar o desempenho do teste.

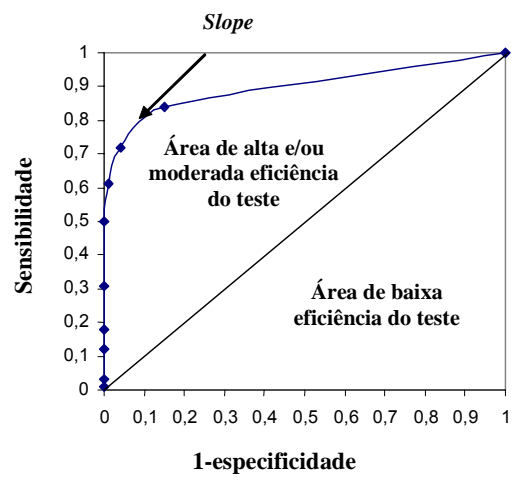

FIgURA 8.6 - Representação esquemática da curva ROC demonstrando interpretação de resultados através das áreas de alta e/ou moderada eficiência e baixa eficiência do teste 
Nesse caso, são possíveis as seguintes interpretações:

- área sob a curva $>1$ : teste altamente eficiente;

- área sob a curva = 1 : teste eficiente;

- área sob a curva entre 0,7 e 0,9: teste moderadamente eficiente;

- área sob a curva entre 0,5 e 0,7: teste pouco eficiente.

Para a construção de uma curva ROC clássica e de uma TG-ROC, será dado um exemplo relatado por Silva et al. (2002), em que os testes de imunofluorescência indireta (IFAT) e imunoenzimáticos (ELISA) para detecção de IgG sérica canina anti-Toxoplasma gondii foram comparados com o teste Western Blotting, considerando-se a reatividade ao antígeno imunodominante do parasito (SAG-1), como marcador molecular da infecção. O primeiro passo é construir as tabelas (tabela 8.1 e 8.2) que vão originar as curvas ROC para IFAT e ELISA (Figura 8.7):

TABela 8.1 - Valores de sensibilidade e especificidade do teste imunofluorescência indireta (IFAT) para detecção de lgG canina anti-Toxoplasma gondii obtidos em diferentes pontos de corte (título sorológico), considerando a reatividade ao antígeno imunodominante (SAG-1) por Western blotting (teste padrão ouro) como marcador da infecção

\begin{tabular}{ccc}
\hline $\begin{array}{c}\text { Ponto de corte } \\
\text { (título) }\end{array}$ & \multicolumn{2}{c}{ IFAT } \\
\cline { 2 - 3 } & Sensibilidade & Especificidade \\
\hline 16 & 1,0 & 0,0 \\
32 & 0,84 & 0,85 \\
64 & 0,72 & 0,96 \\
128 & 0,61 & 0,99 \\
256 & 0,5 & 1,0 \\
512 & 0,31 & 1,0 \\
1024 & 0,18 & 1,0 \\
2048 & 0,12 & 1,0 \\
4096 & 0,03 & 1,0 \\
& 0,01 & 1,0 \\
\hline
\end{tabular}

TABELA 8.2 - Valores de sensibilidade e especificidade do teste imunoenzimático (ELISA) para detecção de IgG canina anti-Toxoplasma gondii obtidos em diferentes pontos de corte (título sorológico), considerando a reatividade ao antígeno imunodominante (SAG-1) por Western blotting (teste padrão ouro) como marcador da infecção

\begin{tabular}{ccc}
\hline $\begin{array}{c}\text { Ponto de corte } \\
\text { (título) }\end{array}$ & \multicolumn{2}{c}{ ELISA } \\
\cline { 2 - 3 } Sensibilidade & Especificidade \\
\hline 32 & 1,0 & 0,0 \\
64 & 0,91 & 0,75 \\
128 & 0,87 & 0,78 \\
256 & 0,70 & 0,95 \\
512 & 0,59 & 1,0 \\
1024 & 0,50 & 1,0 \\
2048 & 0,36 & 1,0 \\
4096 & 0,23 & 1,0 \\
\end{tabular}


Estas tabelas vão originar os seguintes gráficos de curva ROC:

A

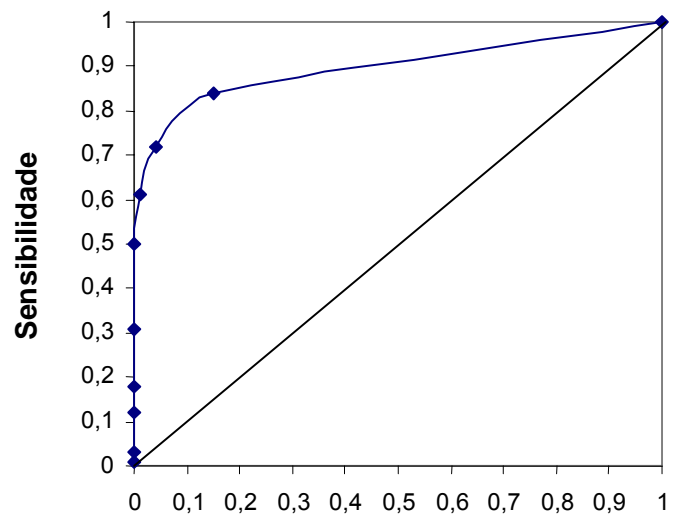

1-especificidade

B

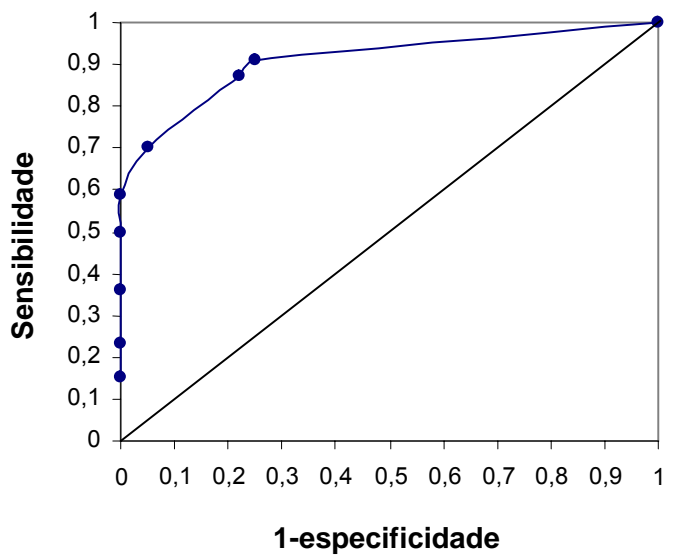

Figura 8.7 - Curvas ROC demonstrando valores de sensibilidade e especificidade dos testes IFAT (A) e ELISA (B) na detecção de IgG sérica canina anti-Toxoplasma gondii comparado com o teste Western Blotting (considerado como padrão ouro) para o diagnóstico da toxoplasmose, admitindo-se diferentes valores de pontos de corte (título sorológico).

Nota-se que, a partir das curvas ROC da Figura 8.7, não se consegue visualizar um valor numérico do cut off, pois só o pesquisador que as construiu tem informações necessárias para isso. Daí faz-se necessário o uso de um novo tipo de análise gráfica: a curva TG-ROC. Ainda utilizando o exemplo acima, pode-se refazer os dois gráficos, em que será possível visualizar os valores de sensibilidade e de especificidade para cada ponto de corte, obtendo-se as seguintes curvas TG-ROC (Figura 8.8): 

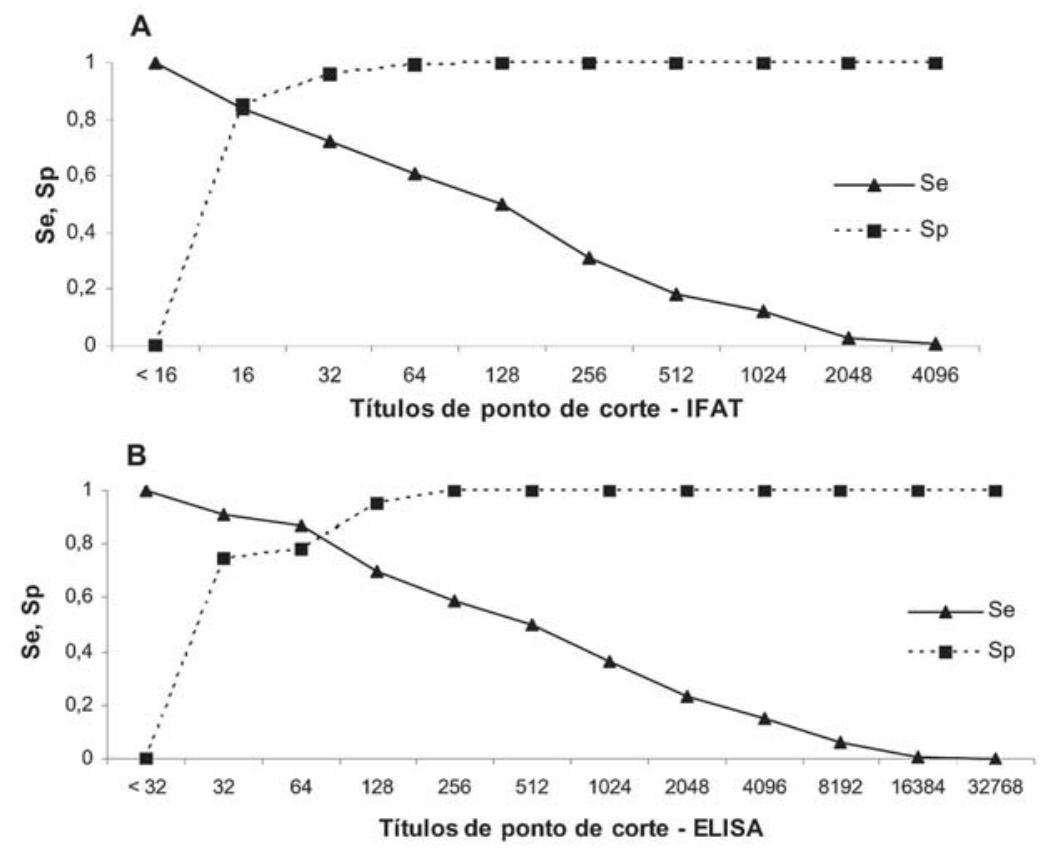

FIGURA 8.8 - Análise TG-ROC em testes de imunofluorescência indireta (IFAT) e imunoenzimáticos (ELISA) para detecção de anticorpos IgG anti-Toxoplasma gondii em soros de cães. Sensibilidade (Se) e especificidade (Sp) de IFAT (A) e ELISA (B) foram determinadas para cada título de ponto de corte, considerando a reatividade contra SAG-1 de $T$. gondii por Western blotting como um marcador da infecção (padrão ouro).

Analisando-se os gráficos acima, fica fácil definir um ponto de corte para os testes IFAT e ELISA, em que os valores de sensibilidade e de especificidade estão otimizados: título de 16 para IFAT e de 64 para ELISA - valores considerados pelos pesquisadores como pontos de corte (títulos sorológicos de triagem) das respectivas técnicas empregadas no estudo.

\section{CONCLUSÃO}

Um teste diagnóstico "ideal" procura classificar corretamente como positiva ou negativa a amostra testada, respectivamente, na presença ou na ausência da doença em questão. Entretanto, na prática não existe um teste ideal. Muitas vezes o teste ideal é o mais rápido, seguro, confiável e de menor custo, disponível naquele momento. Para tanto, no intuito de se encontrar "testes ideais" vários novos testes têm sido desenvolvidos e comparados com os testes disponíveis. 
Vale a pena ressaltar que, mais que memorizar fórmulas, o importante é entender o conceito das definições aqui apresentadas, pois a inversão da posição de entrada dos dados de doença e teste laboratorial na tabela de contingência pode alterar as fórmulas e, assim, os resultados.

Um detalhe importante a ser ressaltado é que sensibilidade, especificidade e razão de probabilidades representam propriedades intrínsecas dos testes, enquanto valores preditivos positivo e negativo representam propriedades tanto dos testes como da população em estudo (prevalência) em relação à doença em questão.

No caso da comparação entre dois testes diagnósticos, é fácil escolher qual é o melhor teste quando um deles apresentar maior sensibilidade e especificidade. Entretanto, quando ambos apresentam valores intermediários de sensibilidade e de especificidade, essa decisão torna-se mais difícil.

Medidas como índice de Youden, razão de probabilidades e área sob a curva $\mathrm{ROC}$ podem ser empregadas para mensurar a habilidade de um teste. Dessa forma, cálculos matemáticos e análises gráficas podem proporcionar uma metodologia teórica de análise do desempenho de testes diagnósticos.

Para se analisarem novos testes diagnósticos, vários programas computacionais estão disponíveis na rede mundial de computadores. Destacam-se cálculos de sensibilidade e especificidade que podem, rápida e facilmente, serem feitos em: <http://www. vademecum.com.br/iatros/index.htm>. Outros parâmetros - como índice de Youden, Kappa, Acurácia e razão de probabilidade, inclusive sensibilidade e especificidade com cálculo de intervalo de confiança (IC 95\%) - poderão ser executados no programa Win Episcope 2.0, disponível no seguinte endereço eletrônico: <http:// www.clive.ed.ac.uk/winepicospe>.

Análises da eficiência de testes diagnósticos são necessárias para se confirmar ou rejeitar uma hipótese diagnóstica, baseada na validação ou não de um procedimento laboratorial. Estas também auxiliam na seleção de um novo teste diagnóstico, como as análises qualitativas que podem influenciar nesta escolha. Cientes desses conceitos, profissionais da área de saúde poderão entender e conduzir melhor os procedimentos envolvidos na utilização dos métodos diagnósticos e na tomada de decisão em cada caso. 


\section{REFERÊNCIAS}

CHILDREN'S MERCY HOSPITAL AND CLINICS. Kappa. Disponível em: <http://www.cmh.edu/stats/definitions.asp >. Acesso em: 11 maio 2005.

DUNLOP, J. et al. Diagnostic test performance. Disponível em: <http://www.epicentre.massey.ac.nz/Downloads/Education/BLMS/ 202251/Dxtests3.ppt>. Acesso em: 22 jun. 2003.

EBELL, M. H. An introduction to information mastery: likelihood ratios. Disponível em: <http://www.poems.msu.edu/infoMastery/ Diagnosis/likelihood_ratios.htm>. Acesso em: 11 maio 2005.

GALEN, R. S.; GAMBINO, S. R. Beyond normality: the predictive value and efficiency of medical diagnosis. New York: Wiley, 1975.

GREINER, M.; SOHR, D.; GÖBEL, P. A modified ROC analysis for the selection of cut-off values and the definition of intermediate results of serodiagnostic tests. Journal of Immunological Methods, Amsterdam, v. 185, n. 1, p. 123-132, Sept.1995.

GUNNARSSON, R. Evaluation of dichotomous diagnostic test. Revised: 10 Nov. 2001. Disponível em: <http://www.infovoice.se/ fou/epv/intro/tests.htm>. Acesso em: 11 maio 2005.

JORGE, M. T.; RIBEIRO, L. A. Epidemiologia clínica. In: Fundamentos para o conhecimento científico. São Paulo: CLR Balieiro, 1999. Cap. 2.

KLOVNING, A. Acuracy. (Slides). Disponível em: <http://www.uib.no/ isf/people/atle/ diagnosis/sld009.htm>. Acesso em: 11 maio 2005.

KLOVNING, $A$. The effect of disease prevalence on the predictive value of diagnostic tests. (Slides). Disponível em: <http://www.uib. no/isf/people/atle/ diagnosis/sld010.htm>. Acesso em: 11 maio 2005.

LUNA FILHO, B. Utilização racional dos testes diagnósticos em cardiologia. Disponível em: <http://www.unifesp.br/dmed/cardio/ch/ utiliza.htm>. Acesso em: 11 maio 2005.

RAMOS FILHO, C. F.; MARTINS, F. S. V. Solicitação e interpretação de testes confirmatórios. Disponível em: <http://www.cives. ufrj.br/dmp/disciplinas/dip/bayes.html>. Acesso em: 11 maio 2005. SILVA, N. M. et al. Optimisation of cut-off titres in Toxoplasma gondii specific ELISA and IFAT in dog sera using immunoreactivity to SAG1 antigen as a molecular marker of infection. Veterinary Journal, London, v. 163, n. 1, p. 94-98, Jan. 2002.

TAPE, T. G. Interpreting diagnostic tests: plotting and interpretating an ROC curve. Disponível em: <http://gim.unmc.edu/dxtests/roc2. $\mathrm{htm}>$. Acesso em: 11 maio 2005. 
YOUDEN, D. Index for rating diagnostic tests. Cancer, Philadelphia, v. 3, n. 1, p. 32-35, 1950.

ZWEIG, M. H.; CAMPBELL, G. Receiver-operating characteristic (ROC) plots: a fundamental evaluation tool in clinical medicine. Clinical Chemistry, Baltimore, v. 39, n. 4, p. 561-577, Apr. 1993. 
9.

\title{
MÉTODOS DE ANÁLISE EM ESTUDOS SOBRE PROGNÓSTICO
}

\author{
Luiz Henrique Guerreiro Vidigal \\ Deise Aparecida de Oliveira Silva
}

\section{INTRODUÇÃO}

Uma vez que um paciente é caracterizado como doente, haverá uma série de questionamentos acerca das conseqüências da doença. Assim, dúvidas sobre limitações funcionais comprometedoras da rotina, dores provocadas pela enfermidade, eficácia e efeitos colaterais advindos do tratamento proposto, bem como tempo de sobrevida em doenças sabidamente letais, devem se respondidas com objetividade.

O prognóstico refere-se à predição do curso futuro de uma doença após ser diagnosticada. Assim, é de interesse do paciente saber sobre a estimativa de vida dele ou dela, ou mesmo se haverá incapacitação para o trabalho, como também para falar, andar e suportar a dor; para o médico, no entanto, é importante ter ele conhecimento sobre o curso geral da doença e se sua conduta é correta ou não.

Para que um tratamento seja eficaz, faz-se necessário obter o maior número possível de informações sobre a história natural e o curso clínico da doença, pois é com base nessas informações que se estabelecem análises quantitativas de sobrevida, avalia-se a eficácia de um novo tratamento e considera-se o impacto deste na sobrevida do paciente.

Análises qualitativas também devem ser apreciadas, pois para muitas doenças a melhoria da qualidade de vida, e não o aumento da sobrevida ou a diminuição da mortalidade, é o desfecho pretendido pelo desenho de um estudo de prognóstico.

\section{HISTÓRIA NATURAL DA DOENÇA VERSUS CURSO CLÍNICO}

O prognóstico pode ser descrito tanto em relação à história natural quanto ao curso clínico de uma doença. 
A evolução sem intervenção médica, denominada história natural da doença, descreve como os pacientes vão evoluir se nada for feito por eles. Estudos prognósticos dessa categoria ocorrem mesmo em países com sistema de saúde avançado, pois doenças que evoluem de maneira muito insidiosa ou inespecífica raramente levam o paciente, com pouca sintomatologia, a procurar serviço médico. Exemplos típicos são o linfoma não-Hodgkin de baixo grau, a síndrome da fadiga crônica e a distimia.

Doenças cujo prognóstico se altera pela terapêutica proposta são descritas pelo seu curso clínico. Habitualmente, são doenças que provocam sintomas comprometedores das funções do paciente ou, no mínimo, sua sensação de bem-estar; ou ocasionam sinais mais alarmantes, tais como febre, sangramentos ou dores incapacitantes. Neoplasias malignas gastrintestinais e disfunções tireoidianas são exemplos importantes.

\section{TEMPO ZERO}

Estudos de prognóstico são, em geral, estudos de coorte em que os pacientes selecionados apresentam uma condição comum (doença) e são acompanhados prospectivamente quanto aos desfechos clínicos, avaliando-se os fatores associados a tais desfechos (fatores prognósticos). Tal situação é semelhante aos estudos de coorte sobre causalidade (fatores de risco). Cumpre ressaltar, no entanto, que os fatores prognósticos são estudados em indivíduos doentes e os fatores de risco em pessoas saudáveis da população.

Ao se realizar um estudo de prognóstico, deve-se deixar claro o momento a partir do qual o paciente foi incluído no estudo, o chamado tempo zero - início dos sintomas, diagnóstico da doença ou início do tratamento - que deve ser o mesmo para todos os pacientes. Os estudos de coorte de prognóstico partem dessa marca no tempo, objetivando a uniformidade de características, bem como avaliar com maior precisão a evolução desses pacientes ao longo do tempo. Isso porque há diferentes momentos em que se pode abordar uma doença. Casos exemplificativos seriam: um paciente ter um tumor benigno de supra-renal evidenciado ao acaso por uma ultra-sonografia de abdômen solicitada por suspeita de cálculos em vesícula biliar - constituindo o chamado "incidentaloma" ou uma análise histopatológica conclusiva de carcinoma broncogênico de pulmão quando a doença já se encontra disseminada. Talvez num futuro não muito distante, o diagnóstico pré-clínico da doença possa ser feito por análise rotineira de DNA, flagrando-se uma alteração genética em estágio inicial. 
A Figura 9.1 representa esquematicamente as diferentes fases do curso clínico de uma doença.

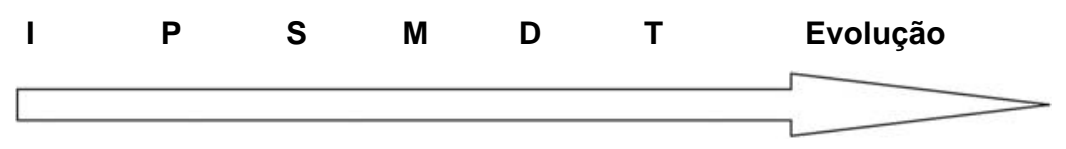

I - instalação biológica da doença
P - evidência patológica da doença
S - sinais e sintomas da doença
M - procura de cuidados médicos
D - diagnóstico
T - tratamento

Figura 9.1 - Fases evolutivas do curso clínico de uma doença

Deve-se esclarecer que, se em determinada amostra de pacientes houver indivíduos incluídos no estudo de prognóstico, mas que estejam em diferentes fases da doença, certamente haverá sobreposição de informações quanto aos diferentes estágios da enfermidade e repercussões específicas. Nesse caso não haverá, portanto, coleta de dados homogêneos e confiáveis sobre a real evolução ao longo do tempo e a partir de um mesmo ponto da doença, com ou sem tratamento.

\section{EXPRESSANDO PROGNÓSTICO}

Ao se descrever o prognóstico, fala-se primariamente de morte, seja em relação ao número de mortos em razão da doença (letalidade) ou de sobreviventes acometidos por uma determinada doença (sobrevida). Como a morte é um fenômeno universal, tal análise não se aplica à sua ocorrência ou não, mas à repercussão de um novo tratamento bem como ao benefício advindo da precocidade diagnóstica sobre as curvas de sobrevida.

Também aqui devem ser incluídas manifestações consideradas importantes para os pacientes, tais como dor, incapacidade funcional e fadiga, por interferirem na qualidade de vida ou no estado funcional deles, e não só mencionar os dados quantitativos, mesmo porque, para alguns tratamentos meramente paliativos ou apenas sintomáticos, o objetivo é justamente a melhoria da qualidade de vida dos pacientes, ainda que se saiba que não haverá possibilidade de sobrevida. Um bom exemplo é o tratamento inicial com zidovudina (AZT) em pacientes HIV positivos com infecção leve sintomática: resultados mostraram um pequeno benefício em retardar a progressão da doença (média de 0,9 meses), mas efeitos 
adversos causados por tal medicamento prejudicaram a qualidade de vida desses pacientes.

O prognóstico de uma doença pode ser caracterizado por valores numéricos expressos por diferentes taxas: letalidade, sobrevida em cinco anos, sobrevida observada, resposta, remissão e recidiva (Quadro 9.1).

\begin{tabular}{|c|c|}
\hline Taxas & Definição \\
\hline Letalidade & $\begin{array}{l}\text { Percentual de pacientes mortos devido à doença } \\
\text { em estudo }\end{array}$ \\
\hline Sobrevida em cinco anos & $\begin{array}{l}\text { Percentual de pacientes sobreviventes cinco anos } \\
\text { a partir de um tempo zero }\end{array}$ \\
\hline Sobrevida observada & $\begin{array}{l}\text { Percentual de pacientes sobreviventes, } \\
\text { independentemente do tempo de evolução }\end{array}$ \\
\hline Resposta & $\begin{array}{l}\text { Percentual de pacientes que mostram sinais de } \\
\text { melhora após intervenção terapêutica e/ou cirúrgica }\end{array}$ \\
\hline Remissão & $\begin{array}{l}\text { Percentual de pacientes que atingem uma fase } \\
\text { indetectável da doença }\end{array}$ \\
\hline Recidiva/Recorrência & $\begin{array}{l}\text { Percentual de pacientes cuja doença retorna após } \\
\text { um intervalo de tempo sem a doença }\end{array}$ \\
\hline
\end{tabular}

QUADRo 9.1 - Medidas de prognóstico

\section{LETALIDADE}

A taxa de letalidade revela a proporção entre o número de pessoas que morrem da doença e o número de pessoas que têm a doença. Seu cálculo é realizado através da seguinte fórmula:

$$
\text { Taxa de letalidade }=\frac{\begin{array}{c}
\mathrm{n}^{\circ} \text { de pessoas mortas em um determinado período de } \\
\text { tempo após a instalação ou diagnóstico da doença }
\end{array}}{\mathrm{n}^{\circ} \text { de pessoas com a doença em questão }}
$$

É importante estabelecer a diferença entre taxa de letalidade e a de mortalidade; nesta, o denominador é composto por todas as pessoas com risco de ter a doença, um universo constante de 100.000 indivíduos, e não apenas pelos doentes (ver capítulo 5 para maiores detalhes).

A taxa de letalidade não pode ser expressa em relação ao tempo e, em geral, é usada para doenças mais agudas, cuja ocorrência de óbito - se houver - é esperada pouco tempo após o diagnóstico, havendo nexo causal consistente entre o óbito e a doença. São exemplos: doenças infecciosas tais como a hantavirose e meningococcemia com purpura fulminans, e eventos cardiovasculares como o infarto agudo do miocárdio extenso, todas elas consideradas altamente letais. 
No caso de doenças crônicas, de longa evolução, em que a morte pode ocorrer até muitos anos após o diagnóstico - ou poder ser determinada por outras causas - , a taxa de letalidade deixa de ser relevante, e são utilizadas outras análises prognósticas mais pertinentes.

\section{SOBREVIDA EM CINCO ANOS}

Medida muito utilizada na prática clínica, sobretudo na avaliação de tratamentos oncológicos, a taxa de sobrevida em cinco anos expressa a porcentagem de pacientes que deverão estar vivos cinco anos após o início do tratamento ou cinco anos após o diagnóstico. Tal período é utilizado em virtude de a maioria das mortes por câncer ocorrer nesse intervalo de tempo, e não pelo fato de haver alguma relação biológica com a doença ou mesmo com a resposta à quimioterapia ou radioterapia, tratamentos usualmente ministrados.

Ao se utilizar essa taxa, algumas limitações são observadas. Nos últimos anos, tais limitações ocorrem de forma crescente pelo fato de grande parte da população se submeter a programas de screening (triagem), como aqueles relacionados às áreas não oncológicas, a exemplo da detecção de diabetes mellitus e de hipertensão arterial, recentemente promovidos no Brasil.

No que se refere às doenças oncológicas, o surgimento de novas tecnologias, sobretudo aquelas relativas ao campo de imagem, como uma simples radiografia de tórax, têm permitido a detecção mais precoce de muitos tipos de câncer, propiciando, se não a possibilidade efetiva de cura, pelo menos maior sobrevida a pacientes acometidos. Com essa maior sobrevida, fica comprometida a análise por tempo determinado, sobretudo por cinco anos.

Na prática clínica, já se considera que uma determinada amostra da população, que conta agora com exames de imagem facilmente acessíveis, apresente um maior número de casos de câncer de pulmão, e seja feita uma detecção mais precoce desta doença. É de se esperar que, dentro dessa amostra, alguns pacientes sobrevivam além dos cinco anos, o que geraria, nesse caso, uma taxa de sucesso. Como exemplo, podemos citar um indivíduo tabagista de 60 anos de idade que procura um serviço médico por apresentar tosse com escarro sanguinolento e emagrecimento sintomas com dois meses de evolução. Esse indivíduo teve um câncer de pulmão diagnosticado em 1998 e morreu em 2001. Pela análise da taxa de sobrevida em cinco anos, ele não é considerado caso de sucesso, por ter sobrevivido apenas por três anos. 
Em outro cenário, tomando-se esse mesmo indivíduo, considere-se que, dessa vez, ele procurou um serviço médico por apresentar um quadro gastrintestinal em 1995. O médico da comunidade, interessado na promoção da saúde como um todo, percebe que se trata de um paciente com sinais clínicos de uma doença pulmonar obstrutiva crônica, solicitando uma radiografia de tórax de rotina, só com o intuito de avaliar alterações esperadas para aquela doença. No entanto, o médico se depara com um nódulo de pequeno tamanho em um dos pulmões, considerado maligno pela biópsia analisada. Submetido à ressecção do nódulo e a sessões de quimioterapia e radioterapia adjuvantes, o paciente sobrevive até 2001 ; mantevese vivo, portanto, por seis anos, pois o diagnóstico fora estabelecido em 1995. Conclui-se que a história natural da doença não se alterou, porém, pela análise da taxa de sobrevida em cinco anos, o mesmo paciente, em dois cenários diferentes, pode ser analisado com resultados distintos.

Outra limitação ocorre com casos diagnosticados em menos de cinco anos, pois o curto período de observação não é suficiente para se coletarem dados necessários à análise em questão.

\section{SOBREVIDA OBSERVADA}

Se a análise da sobrevida em cinco anos tem a séria limitação de não se incluírem nela pacientes com menos de cinco anos de doença, um outro tipo de medida de prognóstico - sobrevida observada - consegue expressar a evolução da doença no que se refere à probabilidade de o indivíduo ainda estar vivo, não importando o tempo de evolução da doença.

Assim, pode-se determinar, ano a ano, a chance que o indivíduo doente tem de se manter vivo. Mais ainda: tem-se a possibilidade de calcular cumulativamente a chance de sobrevida ao final do período observado ao se utilizarem as probabilidades calculadas para cada ano daquele período de tempo.

Para se entender tal processo, será utilizada uma tabela (Tabela 9.1) que inclui indivíduos doentes acompanhados em diferentes períodos: mínimo de um e máximo de cinco anos. Nesse exemplo, estão incluídos cinco grupos de pacientes diagnosticados com uma doença hipotética, com cada grupo incluído em cada um dos cinco anos de seguimento; não se considerará abandono de tratamento a fim de se facilitar a compreensão do processo de cálculo. 
Tabela 9.1 - Pacientes vivos ao final de cada ano em seguimento de cinco anos

\begin{tabular}{ccccccc}
\hline \multirow{2}{*}{$\begin{array}{c}\text { Ano de } \\
\text { inclusão }\end{array}$} & $\begin{array}{c}\text { No de } \\
\text { pacientes } \\
\text { tratados }\end{array}$ & \multicolumn{5}{c}{ № DE PACIENTES VIVOS DURANTE SEGUIMENTO } \\
\cline { 3 - 7 } & 150 & $\mathbf{1 9 9 6}$ & $\mathbf{1 9 9 7}$ & $\mathbf{1 9 9 8}$ & $\mathbf{1 9 9 9}$ & $\mathbf{2 0 0 0}$ \\
\hline 1995 & 146 & 92 & 50 & 22 & 7 & 2 \\
1996 & 135 & & 85 & 43 & 18 & \\
1997 & 148 & & & 97 & 48 & \\
1998 & 129 & & & & 89 & \\
1999 & 708 & & & & & \\
TOTAL & & & & & & \\
\hline
\end{tabular}

Esses dados mostram: no grupo com tratamento iniciado em 1995, dos 150 pacientes incluídos no tratamento, 100 estavam vivos um ano depois, 55 estavam vivos dois anos depois e, assim, por diante. Se todos os pacientes disponíveis para análise nessa tabela fossem utilizados, a taxa de sobrevida de cinco anos não poderia ser utilizada, já que nem todos os 708 indivíduos incluídos foram observados no período.

Para que se possa calcular as probabilidades de sobrevida, ano a ano, assim como a probabilidade acumulada ao fim dos cinco anos de seguimento, os dados contidos na Tabela 9.1 serão dispostos em uma nova tabela (Tabela 9.2). Agrupam-se agora os pacientes a cada ano completo de tratamento, independentemente do ano de inclusão.

TABela 9.2 - Pacientes da Tabela 9.1 ordenados por conclusão de ano de tratamento

\begin{tabular}{ccccccc}
\hline \multirow{2}{*}{$\begin{array}{c}\text { Ano de } \\
\text { inclusão }\end{array}$} & $\begin{array}{c}\text { No de } \\
\text { pacientes } \\
\text { tratados }\end{array}$ & \multicolumn{5}{c}{ № DE PACIENTES VIVOS DURANTE SEGUIMENTO } \\
\cline { 2 - 7 } & $\mathbf{1}^{\circ}$ ano & $\mathbf{2}^{\circ}$ ano & $\mathbf{3}^{\circ}$ ano & $\mathbf{4}^{\circ}$ ano & $\mathbf{5}^{\circ}$ ano \\
\hline 1995 & 150 & 100 & 55 & 22 & 7 & 2 \\
1996 & 146 & 92 & 50 & 20 & 6 & \\
1997 & 135 & 85 & 43 & 18 & & \\
1998 & 148 & 97 & 48 & & & \\
1999 & 129 & 89 & & & & \\
TOTAL & 708 & 463 & 196 & 60 & 13 & 2 \\
\hline
\end{tabular}

Utilizando agora os dados da Tabela 9.2, serão calculadas as probabilidades de sobrevida ao final de cada ano de conclusão do tratamento (P1, P2, P3, P4 e P5), assim como a probabilidade de o paciente estar vivo ao final de cinco anos.

Temos, então:

$\mathrm{P} 1=463 / 708=0,65=65 \%$, ou seja, a probabilidade de o paciente sobreviver ao primeiro ano de tratamento é de $65 \%$; 
$\mathrm{P} 2=196 / 463-89=0,52=52 \%$ é o percentual de chance de sobrevivência ao segundo ano de tratamento entre aqueles que sobreviveram ao primeiro ano.

Uma questão se impõe: por que foram subtraídos os 89 pacientes incluídos em 1999? Pelo fato de terem sido acompanhados apenas durante o primeiro ano.

P3 $=60 / 196-48=0,4=40 \%$ é a probabilidade de sobrevida ao final do terceiro ano de tratamento entre os sobreviventes ao segundo ano de tratamento. Dessa vez, foram excluídos 48 pacientes que só foram seguidos por apenas dois anos.

$\mathrm{P} 4=13 / 60-18=0,31=31 \%$ é a probabilidade de sobrevida ao final do quarto ano de tratamento entre os pacientes que sobreviveram ao terceiro ano. Dessa vez, foram excluídos 18 pacientes que foram seguidos por apenas três anos.

P5 $=2$ / $13-6=0,29=29 \%$ é a probabilidade de sobrevida ao final do quinto ano de tratamento para aqueles que estavam vivos ao final de quatro anos de tratamento. Dessa vez, excluíram-se seis pacientes que foram seguidos por apenas quatro anos.

E quanto às probabilidades cumulativas? Qual é a probabilidade de sobrevida após dois anos de tratamento entre os que iniciam o tratamento? Ou então: qual é a probabilidade final após cinco anos de seguimento em relação a todos que iniciaram o tratamento?

No caso em questão, como se questiona a probabilidade de sobrevida após um ou mais anos, deve-se multiplicar as probabilidades calculadas para cada ano e que elas estejam de acordo com o período desejado. Assim, qual é a probabilidade de um indivíduo incluído no estudo estar vivo ao final de três anos de tratamento? A resposta é $13 \%$. Esse resultado é produto da multiplicação das probabilidades P1, P2 e P3, ou seja, das probabilidades calculadas para cada um dos três primeiros anos. Assim:

$\mathrm{P} 1 \times \mathrm{P} 2 \times \mathrm{P} 3=0,65 \times 0,52 \times 0,4=0,13=13 \%$

A Tabela 9.3, a seguir, demonstra as probabilidades cumulativas de sobrevida para os diferentes períodos de tempo já citados.

TABELA 9.3 - Probabilidades cumulativas de sobrevida

\begin{tabular}{|c|c|c|c|}
\hline $\begin{array}{c}\text { SOBREVIDA } \\
\text { POR }\end{array}$ & Probabilidades & Cálculo das Probabilidades & P FINAL \\
\hline 1 ano & $\mathrm{P} 1$ & 0,65 & $65 \%$ \\
\hline 2 anos & $\mathrm{P} 1 \times \mathrm{P} 2$ & $0,65 \times 0,52=0,34$ & $34 \%$ \\
\hline 3 anos & $\mathrm{P} 1 \times \mathrm{P} 2 \times \mathrm{P} 3$ & $0,65 \times 0,52 \times 0,4=0.13$ & $13 \%$ \\
\hline 4 anos & $\mathrm{P} 1 \times \mathrm{P} 2 \times \mathrm{P} 3 \times \mathrm{P} 4$ & $0,65 \times 0,52 \times 0,4 \times 0,31=0,04$ & $4 \%$ \\
\hline 5 anos & $\mathrm{P} 1 \times \mathrm{P} 2 \times \mathrm{P} 3 \times \mathrm{P} 4 \times \mathrm{P} 5$ & $0,65 \times 0,52 \times 0,4 \times 0,31 \times 0,29=0,01$ & $1 \%$ \\
\hline
\end{tabular}


O que se observa neste exemplo hipotético é que há um aumento gradativo da mortalidade com o passar dos anos, de maneira que os indivíduos, ano a ano, apresentam menor chance de sobrevida, com apenas $1 \%$ de todos eles podendo estar vivos ao final dos cinco anos. Tal situação é típica, por exemplo, de neoplasias malignas pouco responsivas à quimioterapia e/ou radioterapia, ou que, na maioria das vezes, são detectadas já com metástases disseminadas, como o carcinoma de pequenas células de pulmão, o melanoma e o câncer de pâncreas.

A curva de sobrevida a seguir ilustra os números já apresentados, partindo de 708 pacientes e chegando a dois pacientes ao final dos cinco anos de observação (Figura 9.2).

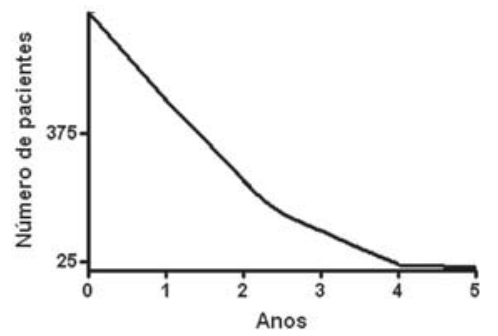

Figura 9.2 - Curva de sobrevida observada ao final de cinco anos

\section{CURVAS DE SOBREVIDA}

As curvas de sobrevida podem assumir diferentes aspectos, dependendo do número de pacientes incluídos e acompanhados em um estudo prognóstico de coorte (pequeno ou grande). Assim, quanto menor for o número de pacientes, mais a curva assume um aspecto de "degraus" (Figura 9.3A), que correspondem à morte de cada um dos pacientes do estudo. Por outro lado, quanto maior for o número de indivíduos analisados, mais o tamanho dos degraus tende a diminuir e mais a curva se torna linear ou "lisa" (Figura 9.3B).

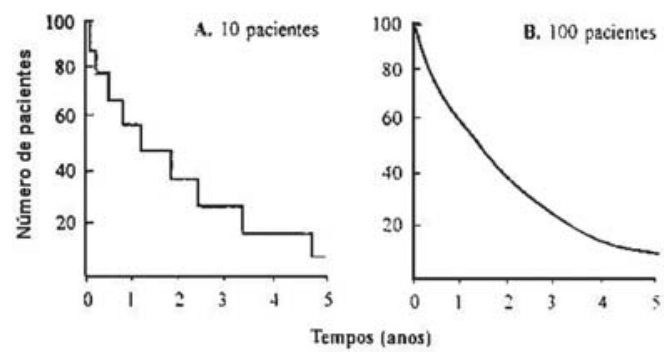

Figura 9.3 - Curvas de sobrevida para estudos prognósticos de coorte com pequeno (A) e grande (B) número de pacientes observados por um período de cinco anos. Fonte: Adaptado de Fletcher, Fletcher e Wagner (1996). 
Há outras doenças que apresentam grande taxa de mortalidade no primeiro ano - ou mesmo nos primeiros dias - de acometimento. Contudo, a taxa de mortalidade tende a uma estabilização subseqüente, com grande probabilidade de sobrevida entre os não dizimados pela doença no início.

A Figura 9.4 ilustra como quatro condições clínicas diferentes, determinando a mesma taxa de sobrevida (10\%) ao final de cinco anos, apresentam curva de sobrevida de pacientes bem distinta ao longo do período observado.
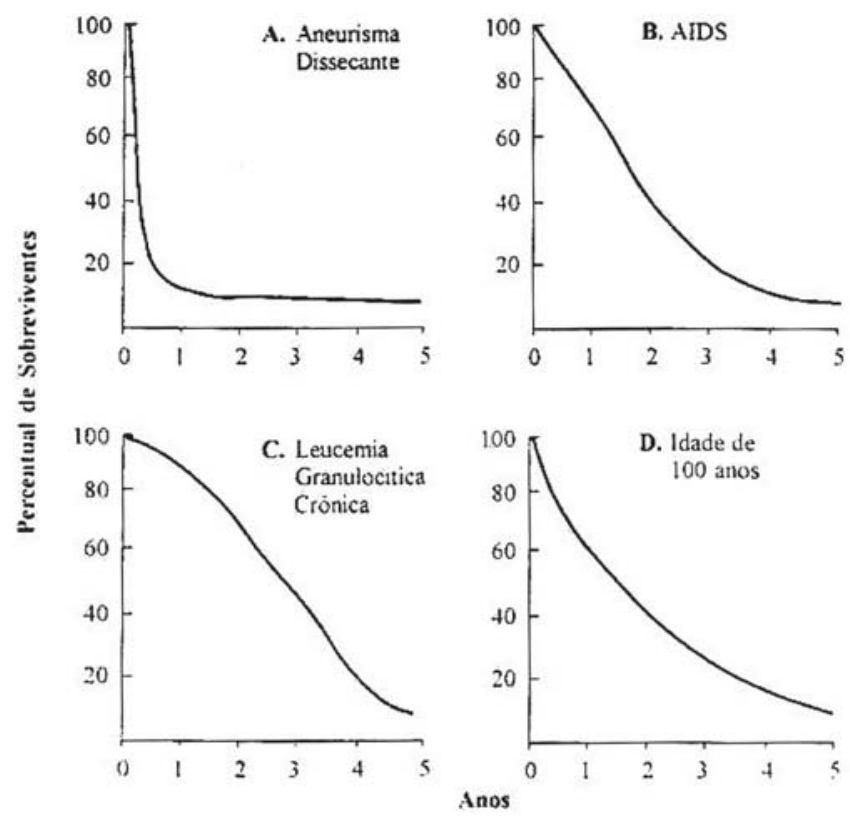

Figura 9.4 - Curvas de sobrevida para diferentes doenças.

Fonte: Adaptado de Fletcher, Fletcher e Wagner (1996).

Como se pode observar, a condição de uma idade de 100 anos (Figura 9.4D) apresenta curva de sobrevida estável ao longo do tempo, enquanto os portadores de AIDS (Figura 9.4B) mostram tendência um pouco mais acentuada ao óbito, após um período inicial mais favorável em relação aos muito idosos. Já os portadores de leucemia mielóide crônica (Figura 9.4C) apresentam curva típica de doença cuja transformação blástica e, por conseqüência, o agravamento da condição patológica ocorrem após intervalo médio de cerca de três a quatro anos, depois de um período em que a maioria dos doentes se encontra em uma fase controlada da doença. Finalmente, condições severamente graves no período agudo, como o aneurisma dissecante de aorta (Figura 9.4A), levam a óbito, em 
questão de dias ou mesmo horas, uma altíssima porcentagem de seus portadores, com baixa porcentagem de sobreviventes posteriormente - os quais, após o período mais crítico, têm probabilidade alta de sobrevivência, pelo menos em médio prazo.

Tal análise crítica mostra como a taxa de sobrevida de cinco anos traduz apenas o número de pacientes para os quais há expectativa de que estejam vivos ao final do tempo analisado. Aqui, cabe ao clínico expressar como será a evolução dos óbitos - ou seja, compreender e explicar as diferentes curvas produzidas com as diferentes amostras de populações estudadas.

\section{ANÁLISE DE SOBREVIDA (KAPLAN-MEIR)}

A análise de sobrevida de Kaplan-Meir foi desenvolvida para descrição não só dos dados de sobrevida ou letalidade, mas também de qualquer evento que possa ocorrer durante o seguimento - a exemplo da recidiva da doença. Uma curva de sobrevida típica e detalhada dessa análise está ilustrada na Figura 9.5. O número de pacientes em risco de morrer está indicado, com freqüência, nos intervalos de tempo; assim, eliminam-se os pacientes que já morreram nos intervalos anteriores ou os que se desligaram do estudo por algum motivo (censurados). Dessa forma, a probabilidade de sobrevida é calculada pela razão entre o número de sobreviventes e o número de pacientes em risco de morrer em cada intervalo.

Do início da observação até qualquer ponto no tempo, a probabilidade de sobrevivência é estimada com base na probabilidade cumulativa de sobrevivência a cada um dos intervalos de tempo anteriores e é mais precisa que as probabilidades determinadas isoladamente para cada intervalo. A precisão de tais estimativas depende do número de eventos observados; assim, as estimativas do lado esquerdo da curva são mais confiáveis (maior número de pacientes em risco) do que aquelas do lado direito da curva no final do seguimento (menor número de pacientes em risco), que devem ser interpretadas com cautela. 


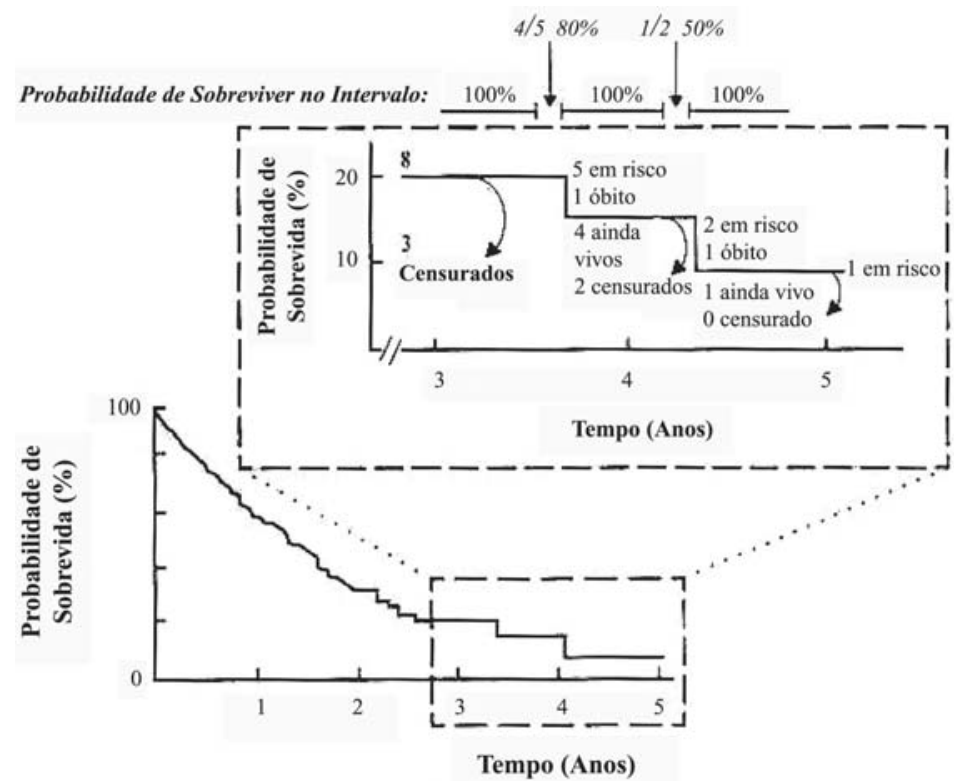

Figura 9.5 - Curva de sobrevida típica da análise de Kaplan-Meir.

Fonte: Adaptado de Fletcher, Fletcher e Wagner (1996).

\section{FATORES PROGNÓSTICOS}

As análises já comentadas são, certamente, as de maior domínio tanto do profissional de saúde como do público em geral. Isso porque não só em algumas circunstâncias oficiosas, mas também no dia-a-dia, pelos meios de comunicação, são divulgados dados oficiais sobre a letalidade de certa doença infecciosa numa epidemia, a alta mortalidade de neoplasias malignas evitáveis como nas campanhas educativas sobre câncer de colo de útero, por exemplo - e a certeza quase absoluta de óbito em relação a um paciente aidético - também para enfatizar a prevenção simples ante uma doença tão devastadora.

Cabe ressaltar, porém, que outras taxas, além da letalidade, sobrevida em cinco anos e sobrevida observada, são de extrema importância para médicos e pesquisadores, por causa da necessidade de mensuração não só do desfecho de morte, mas também das taxas de resposta (percentual de pacientes que mostra evidência de melhora após intervenção terapêutica), de remissão (percentual de pacientes que atingem uma fase indetectável da doença) ou mesmo de recidiva (percentual de pacientes cuja doença retorna após intervalo livre) de certas doenças submetidas a tratamentos específicos (Quadro 9.1). Assim, já são conhecidos, há algum 
tempo, critérios prognósticos de várias doenças, derivados da observação de que sua presença se vincula a um melhor ou pior prognóstico de resposta ao tratamento, o que reflete diretamente na taxa de sobrevida. Como exemplos, podem ser citados os critérios de Hanson utilizados para prognosticar o curso de uma pancreatite aguda, tais como os altos níveis de creatinina $(>1,4) \mathrm{e}$ a presença do auto-anticorpo anti-Ro, os quais prevêem doença renal terminal para pacientes portadores de glomerulonefrite lúpica, assim como uma evolução ruim da esclerose múltipla em pacientes com sintomas motores e cerebelares aliados a uma doença progressiva desde sua instalação.

Tais fatores são utilizados não para a tomada de decisão do tratamento, e sim para se delinear, desde o início, o que se quer e se pode aguardar do tratamento proposto, fato extremamente valioso não só para quem trata, como também para um paciente ansioso por resultados - ainda que seja discutível, e talvez até irresponsável, transmitir esperança em forma de números.

Como os termos resposta, remissão e recidiva soam quase como sinônimos de análise de tratamento de neoplasias, tais critérios prognósticos serão exemplificados citando-se uma doença linfoproliferativa. A Tabela 9.4 relaciona fatores prognósticos à sobrevida livre de doença em cinco anos (pacientes vivos com remissão da doença) entre pacientes com linfoma de Hodgkin. Os sete fatores prognósticos são:

1) sexo masculino;

2) idade maior que 45 anos;

3) estágio avançado da doença (IV);

4) albumina sérica menor que $4,0 \mathrm{~g} / \mathrm{dL}$;

5) hemoglobina menor que $10,5 \mathrm{~g} / \mathrm{dL}$;

6) leucócitos maior que $15.000 / \mathrm{mL}$;

7) linfócitos menores que $600 / \mathrm{mL}$ ou menores que $8 \%$ do total de leucócitos.

Quanto maior o número desses fatores, até um máximo de cinco, menor é a taxa de pacientes vivos com remissão da doença.

TABela 9.4 - Relação entre número de fatores prognósticos e evolução livre da doença de Hodgkin

\begin{tabular}{cc}
\hline $\begin{array}{c}\text { № de fatores prognósticos } \\
\text { presentes }\end{array}$ & $\begin{array}{c}\text { Sobrevida livre de insucesso } \\
\text { em } \mathbf{5} \text { anos (\%) }\end{array}$ \\
\hline 0 & 84 \\
1 & 77 \\
2 & 67 \\
3 & 60 \\
4 & 51 \\
5 & 42 \\
\hline
\end{tabular}


Tem-se, assim, uma relação objetiva entre achados clínicolaboratoriais e a taxa esperada de pacientes vivos com remissão da doença ao final de cinco anos.

Um outro exemplo da influência de múltiplos fatores prognósticos na sobrevida pode ser observado na Figura 9.6, que ilustra a curva de sobrevida de pacientes com AIDS de acordo com seu estádio prognóstico. Para essa doença, foi atribuído um ponto à presença de cada um dos seguintes fatores prognósticos:

1) diarréia grave ou albumina sérica menor que $2 \mathrm{~g} / \mathrm{dL}$;

2) déficit neurológico;

3) $\mathrm{pO}_{2}$ menor ou igual a $50 \mathrm{~mm} \mathrm{Hg}$;

4) hematócrito menor que $30 \%$;

5) contagem de linfócitos menor que $150 / \mathrm{mL}$;

6) contagem de leucócitos menor que $2.500 / \mathrm{mL}$;

7) contagem plaquetária menor que $14.000 / \mathrm{mL}$.

De acordo com o escore total dos fatores prognósticos, os pacientes foram classificados em estádio I (0 ponto), estádio II (1 ponto) e estádio III (2 pontos ou mais), apresentando diferentes curvas de sobrevida para cada estádio. Assim, para pacientes do estádio I houve sobrevida maior (mediana de 11,6 meses), quando comparados a pacientes do estádio II (sobrevida mediana de 5,1 meses) e estádio III (sobrevida mediana de 2,1 meses).

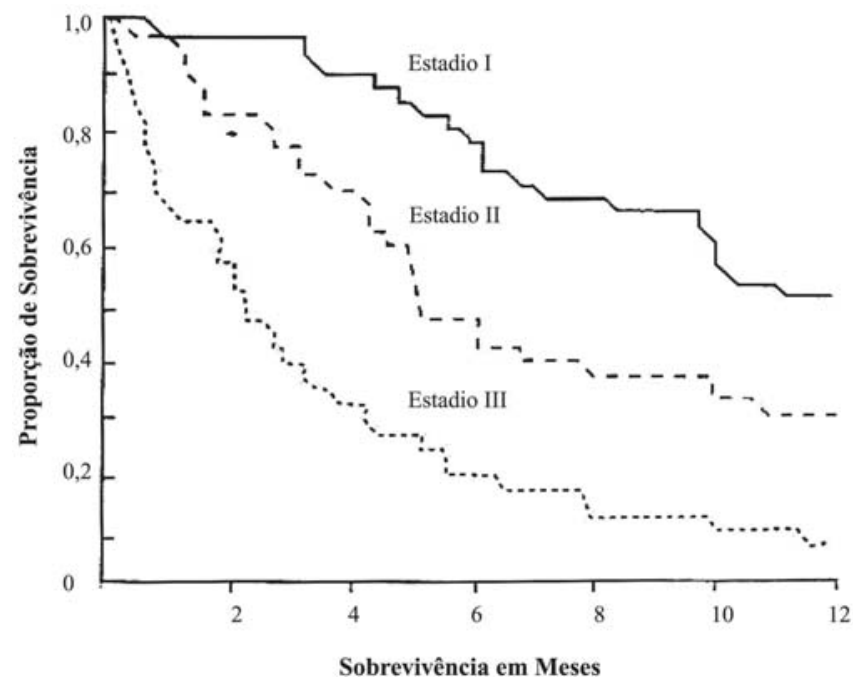

Figura 9.6 - Curvas de sobrevida de pacientes com AIDS em diferentes estádios prognósticos (I, II e III)

Fonte: Adaptado de Fletcher, Fletcher e Wagner (1996). 


\section{CONCLUSÃO}

Quantificações exatas, expressas em porcentagens, foram desenvolvidas na tentativa de traduzir o que se deve esperar da evolução de várias doenças - seja da história natural, seja do curso clínico. Taxas como letalidade, sobrevida em cinco anos, sobrevida observada, resposta, remissão e recidiva são objeto de análise de numerosos trabalhos originais a cada dia na literatura científica mundial. Nesse sentido, cabe ao profissional de saúde conhecer e dominar tais análises para estar apto a deixar claro ao paciente o que se deve esperar da doença e do tratamento, quando proposto.

\section{REFERÊNCIAS}

FLETCHER, R. H.; FLETCHER, S. W.; WAGNER, E. H. Epidemiologia clínica: elementos essenciais. 3. ed. Porto Alegre: Artes Médicas, 1996. 281p.

GORDIS, L. Epidemiology. Philadelphia: W. B. Saunders, 1996. JORGE, M. T.; RIBEIRO, L. A. Fundamentos para o conhecimento científico:áreas de saúde São Paulo: CLR Balieiro, 1999.

KORBET, S. M. et al. Factors predictive of outcome in severe lupus nephritis. American Journal of Kidney Diseases, Minneapolis, v. 35, n. 5, p. 904-914, 2000.

ZAGO, M. A.; FALCÃO, R. P.; PASQUINI, R. Hematologia: fundamentos e prática. São Paulo: Atheneu, 2001. 


\title{
MÉTODOS DE ANÁLISE EM ESTUDOS SOBRE TERAPÊUTICA
}

\author{
Luiz Henrique Guerreiro Vidigal
}

\section{INTRODUÇÃO}

O desenvolvimento de métodos voltados à detecção precoce ou mais acurada, seja por implementação de screening ou por aumento da sensibilidade de exames, aliado a medidas que objetivem analisar a história natural de uma doença, tem permitido aprimorar diagnósticos e prognósticos. Assim, a função da terapêutica, no que se refere a evitar ou mesmo retardar comprometimentos funcionais ou mortes decorrentes das doenças, é essencial, e um tratamento eficaz, necessariamente também efetivo, deve ser a meta a ser atingida ante qualquer doença, seja qual for a etiologia.

\section{EFICÁCIA VERSUS EFETIVIDADE}

Os termos eficácia e efetividade são rotineiramente aplicados em estudos terapêuticos e devem ser bem caracterizados. $\mathrm{Na}$ verdade, eficácia se refere à demonstração de que dado tratamento funciona ou não; logo, tratamento eficaz é o que produz efeitos esperados ou desejados em pacientes que o receberam. Efetividade, por sua vez, vincula-se à demonstração de que determinado tratamento funciona sem provocar efeitos colaterais, ou seja, um tratamento efetivo é aquele que traz mais benefício do que prejuízo quando prescrito.

Pacientes cujas enfermidades são evitáveis, tratáveis ou cujos sintomas podem ser atenuados - ainda que minimamente - devem receber tratamento bem definido, a ponto de ser proposto com segurança quanto à eficácia e à tolerabilidade dos efeitos colaterais a ele inerentes.

Para que uma nova terapêutica seja considerada eficaz, o ideal é usá-la em seres humanos experimentalmente, comparando com pacientes não tratados e com aqueles tratados com uma droga cujo uso já é habitual e considerado, até então, o mais eficaz. Assim, 
os estudos experimentais, sobretudo os randomizados, objetivam testar certa terapia que possa ser comprovada como superior àquela utilizada até então, tendo em vista a melhoria do prognóstico do paciente.

\section{ESTABELECENDO EFEITOS DE UM TRATAMENTO}

Tratamento e medicamento não são termos sinônimos, visto que o primeiro pode se pautar em medidas não farmacológicas, tais como: exercício físico e dieta para pacientes hipertensos, cirurgias oncológicas ou mesmo a simples interrupção de um vício - a exemplo da cessação do tabagismo em pacientes com enfisema pulmonar.

Qualque que seja o tipo de tratamento ministrado, a padronização se deve a estudos demonstrativos da eficácia; por serem estes de diferentes tipos, as conclusões devem se pautar na forma como o tratamento foi conduzido, bem como no desenho proposto.

Os requisitos considerados como meta e que devem ser previstos no desenho de qualquer estudo bem conduzido podem ser assim discriminados:

- delineamento do problema a ser resolvido, daquilo que deve ser testado e do elemento de comparação;

- critérios de inclusão e exclusão de pacientes bem definidos;

- desfechos (endpoints) bem definidos;

- tamanho da amostra corretamente calculado;

- comparação entre grupos (grupo-controle);

- homogeneidade dos grupos comparados;

- imparcialidade do médico e do paciente tratado;

- avaliação estatística adequada.

A seguir, serão apresentados os diferentes tipos de estudos comparativos e não comparativos - estes incluirão tanto estudos observacionais quanto experimentais. Com esse procedimento, busca-se mostrar: as vantagens e desvantagens de cada um deles, a superioridade dos ensaios clínicos (ou estudos experimentais, como também são conhecidos) sobre os demais e revelar a importância do processo de randomização em um estudo avaliador do sucesso de dado tratamento, qualquer que seja a natureza dele. 


\section{ESTUDOS NÃO-COMPARATIVOS}

Tais estudos relatam tão-somente a experiência com pacientes submetidos a um determinado tipo de tratamento, sem compará-los a pacientes não tratados ou tratados com outra modalidade terapêutica padronizada ou aceita como eficaz até então. Tanto o relato de caso quanto a denominada série de casos são estudos observacionais descritivos que relatam a experiência com um ou vários pacientes submetidos a algum tratamento. Como não há comparação, a dúvida sobre a real eficácia terapêutica subsiste, já que uma simples pergunta não pode ser respondida: se houvesse um grupo-controle não tratado (ou tratado por outra modalidade), poderia este apresentar os mesmos resultados ou resultados melhores que se encontraram entre os tratados?

Um exemplo hipotético seria submeter um paciente ou grupo de pacientes portadores de sinusite aguda a tratamento à base de medicamento antimicrobiano. Aqui se impõe um questionamento: se ocorrer melhora do quadro em todos os pacientes, pode-se chegar à conclusão de que o tratamento é eficaz? Se considerarmos a melhora espontânea na maioria das sinusites agudas, ou então que os pacientes em questão poderiam ter sido acometidos não por um processo bacteriano, e sim viral, a resposta é negativa. A esse propósito, considerem-se dois aspectos fundamentais: primeiro, a confirmação da etiologia bacteriana; segundo, a comparação com um grupo não tratado, embora este não se enquadre como proposta para esse tipo de estudo.

\section{ESTUDOS COMPARATIVOS}

Os estudos comparativos são delineados para se testar a eficácia de algum tratamento pela comparação entre grupos e, assim, permitir perceber ou não diferenças entre grupos tratados e não tratados, ou entre grupos de pacientes submetidos a tratamentos diferentes. Tais estudos podem ser observacionais analíticos (coorte histórica e coorte contemporânea) ou experimentais (ensaios clínicos).

Os estudos terapêuticos observacionais representam um caso especial dentre os estudos prognósticos, em que o fator prognóstico de interesse é uma intervenção terapêutica. São vantajosos no contexto da factibilidade, mas extremamente susceptíveis a diferenças sistemáticas nos grupos não relacionados com o tratamento - o que pode levar a conclusões enganosas sobre os efeitos da terapêutica.

Os estudos experimentais ou ensaios clínicos representam um tipo especial de estudo de coorte em que as condições do estudo 
- seleção dos grupos de tratamento, natureza das intervenções, acompanhamento e aferição dos desfechos - são mais controladas por se aproximarem de um experimento feito em laboratório.

Diferentes tipos de grupos de comparação podem ser usados para validar os resultados de estudos experimentais:

1. sem intervenção - a comparação do grupo experimental (tratado) é feita com um grupo de pacientes que não recebe nenhum tipo de tratamento; avalia-se assim o efeito total dos cuidados da saúde (específicos e inespecíficos);

2. observação - a comparação do grupo experimental (tratado) é feita com um grupo de pacientes que não recebe nenhum tratamento, mas são observados. Essa atenção especial dada aos pacientes, independentemente da natureza da intervenção, induz a uma mudança do comportamento deles e leva ao chamado efeito Hawthorne. Assim, a comparação com esse grupo avalia o efeito do tratamento além do efeito Hawthorne.

3. tratamento placebo - a comparação do grupo experimental (tratado) é feita com um grupo de pacientes que recebem placebo (intervenção indistinguível do tratamento ativo - na aparência física, cor, sabor e odor - mas sem ação específica conhecida). Exemplos típicos são pílulas de açúcar e injeções de solução salina. Pacientes que recebem placebo podem apresentar melhora clínica, levando ao chamado efeito placebo.

4. tratamento usual - a comparação do grupo experimental (tratado) é feita com um grupo de pacientes que recebe o tratamento usual ou convencional, sabidamente eficaz; portanto, ético.

No que se refere a estudos terapêuticos experimentais, é lícito mencionar que os efeitos totais dos tratamentos correspondem à soma da melhora espontânea, das respostas inespecíficas e dos efeitos específicos da intervenção. Torna-se fundamental a avaliação dos resultados obtidos mediante os diferentes grupos de comparação para se eliminarem os efeitos inespecíficos e, de fato, validarem os efeitos específicos da intervenção em questão.

\section{CoORTE HISTÓRICA}

Uma forma prática de se estabelecer comparação entre terapias é recorrer a registros de dados sobre pacientes submetidos anteriormente à outra modalidade de tratamento. $\mathrm{O}$ objetivo é demonstrar que uma nova terapia disponível tem eficácia superior àquela já instituída, fazendo uso dos dados disponíveis nas anotações históricas dos pacientes. Infelizmente, essa forma "tentadora" de comparação tem limitações, a saber: 
1) quando se propõe o tratamento para determinada doença com uma nova droga, estabelecem-se critérios de inclusão bem definidos, que devem incluir pacientes com perfil adequado, além de se prever o universo de informações a ser coletado para que os desfechos pré-definidos possam ser avaliados. Esses critérios e algumas (às vezes várias) informações necessárias talvez não estejam disponíveis no registro dos pacientes - mesmo porque, é possível que tais pacientes tenham sido tratados e acompanhados sem a intenção de se fazer um estudo comparativo;

2) há de se considerar a evolução de terapias de suporte, tais como: desenvolvimento de novos antimicrobianos e de equipamentos hospitalares mais sofisticados, como também a mudança de estilo de vida, fatores presentes em estudos realizados em épocas diferentes e que podem ter repercussão, seja qual for o efeito terapêutico da droga.

A Tabela 10.1 mostra tratamento de glomerulonefrite lúpica classe IV com micofenolato mofetil (MMF) - imunossupressor mais recente - , comparando-se a eficácia deste com controles históricos realizados com a mesma doença quando tratada de forma tradicional com ciclofosfamida (CFM). As informações de interesse para o estudo com MMF estão delineadas na coluna "variáveis", com sua disponibilidade entre os controles pretendidos, expressa em porcentagem, exceto o número de pacientes.

TABELA 10.1 - Disponibilidade de variáveis de interesse na comparação entre ciclofosfamida e micofenolato mofetil no tratamento da glomerulonefrite lúpica

\begin{tabular}{cc}
\hline $\begin{array}{c}\text { Variáveis de interesse } \\
\text { no estudo }\end{array}$ & $\begin{array}{c}\text { Disponibilidade dos dados } \\
\text { entre os controles históricos }\end{array}$ \\
\hline Número de pacientes & 10 \\
Nível inicial de creatinina & $9(90 \%)$ \\
Presença de anti-DNA & $5(50 \%)$ \\
Presença de anti-Ro & $10(100 \%)$ \\
Proteinúria quantificada & $6(60 \%)$ \\
Tempo até remissão & $4(40 \%)$ \\
Efeitos colaterais & $3(30 \%)$ \\
Níveis pressóricos & $8(80 \%)$ \\
Dosagem de C3 e C4 & $6(60 \%)$ \\
\end{tabular}

No exemplo, foi imposta uma séria limitação à comparação proposta, seja porque os exames não foram realizados ou porque não foram anotados, ou os laudos tenham se perdido. Dados essenciais como efeito colateral estão disponíveis só para $30 \%$ dos controles históricos pretendidos, que, somados às demais limitações, 
inviabilizam uma comparação abrangente e confiável. Tal situação demonstra a diferença entre um estudo conduzido com o firme propósito de comparação e tratamentos realizados no passado sem rigor científico.

\section{COORTES CONTEMPORÂNEAS VERSUS ESTUDOS EXPERIMENTAIS}

A estrutura de um estudo experimental ou ensaio clínico é ilustrada na Figura 10.1. Os pacientes do estudo (amostra) são selecionados entre os pacientes com a condição de interesse (população) e, então, divididos aleatoriamente (randomização) em dois grupos: 1) grupo experimental ou tratado, submetido à intervenção terapêutica em questão; e 2) grupo-controle ou de comparação, não submetido à intervenção terapêutica (não tratado). Os dois grupos são observados quanto à evolução clínica com o tempo (desfechos), e as diferenças observadas entre os grupos são atribuídas ao tratamento em questão.

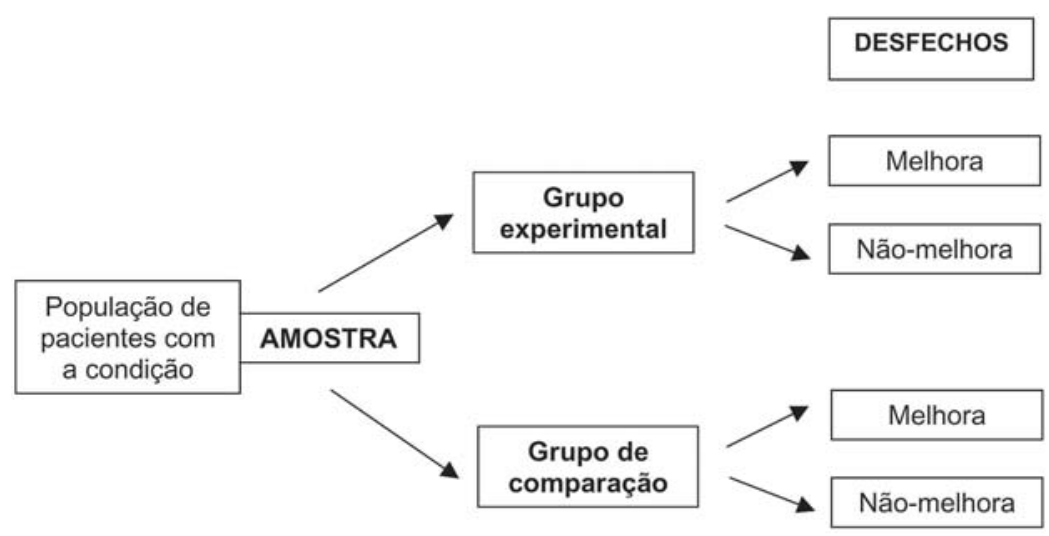

Figura 10.1 - Estrutura de um estudo experimental ou ensaio clínico Fonte: Adaptado de Fletcher, Fletcher e Wagner (1996).

Para se demonstrar a importância da randomização, será estabelecido um paralelo entre um estudo observacional com pacientes não randomizados e um estudo experimental com pacientes randomizados (Figura 10.2).

No exemplo, há dois grupos hipotéticos, cada um com 200 pacientes portadores de linfoma não-Hodgkin difuso de grandes células $\mathrm{B}$ - o tipo histológico mais comum e agressivo entre aqueles linfomas. Considere-se que todos os pacientes apresentam a mesma média de idade, se encontram no mesmo estágio da doença e são todos submetidos à primeira sessão de quimioterapia. 
(A) Estudo observacional

PACIENTES

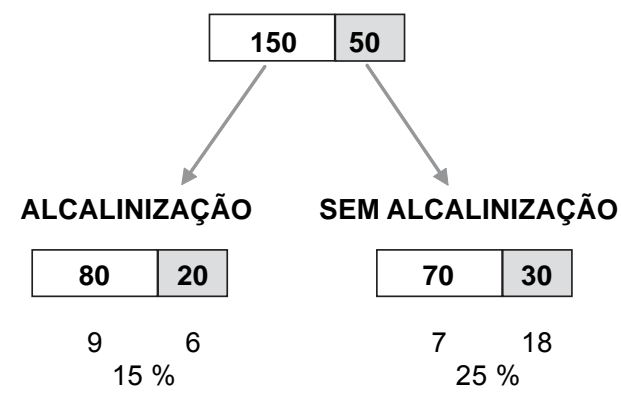

ÓBITOS:

LETALIDADE:

$15 \%$

(B) Estudo experimental

PACIENTES

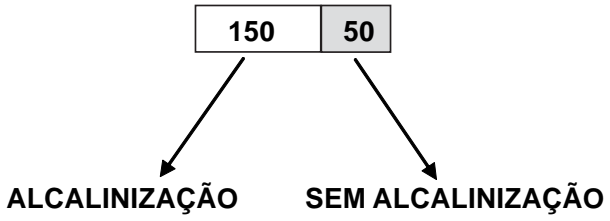

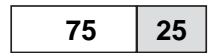

ÓBITOS:

LETALIDADE:

15

FigurA 10.2 - Estudo observacional $(A)$ versus estudo experimental $(B)$ utilizando grupos de pacientes $(n=200)$ portadores de linfoma não-Hodgkin sob quimioterapia e submetidos ou não à alcalinização urinária, em presença (quadrados sombreados) ou ausência de febre (quadrados não sombreados). No estudo experimental (B), os pacientes foram randomizados quanto à presença ou ausência de febre

Como se sabe que a lise das células neoplásicas libera grande quantidade de bases purínicas e pirimidínicas na circulação, com posterior formação de ácido úrico, defende-se a hiper-hidratação desses pacientes durante a quimioterapia, a fim de evitar a instalação de insuficiência renal por necrose tubular aguda. A alcalinização urinária é reconhecidamente eficaz em termos teóricos, mas não há comprovação prática consistente. Assim, nesse exemplo, uma metade receberá tal intervenção, e a outra ficará sem a alcalinização - mas serão hiper-hidratados.

Há, porém, entre eles, 50 pacientes febris representados no quadrado sombreado. $E$ a alocação entre os grupos submetidos ou não à alcalinização urinária é diferente nos dois tipos de estudo apresentados. Com isso, a taxa de letalidade entre os pacientes submetidos à quimioterapia apresenta diferença.

Ao se analisar o estudo observacional (uma coorte contemporânea), tem-se a nítida impressão de que, como a taxa de letali- 
dade entre os pacientes submetidos à quimioterapia e à alcalinização urinária foi de $15 \%$ - portanto inferior a $25 \%$ entre os não alcalinizados -, tal intervenção pode, de fato, ter sido eficaz. No entanto, ao se alocarem os 50 pacientes febris igualmente nos dois grupos, percebe-se que não houve diferença na taxa de letalidade entre os pacientes submetidos à alcalinização e aqueles sem esse tipo de abordagem terapêutica. Nesse caso, o fato de os pacientes estarem febris - portanto com alguma infecção potencial - é o que deve ter concorrido para a maior letalidade no estudo não randomizado, e não o fato de se submeter ou não o paciente à alcalinização urinária.

Tem-se aqui comprovação de como a randomização é fundamental à alocação de pacientes de maneira aleatória para se compararem pacientes que pertencem a cada um dos grupos segundo características como: sexo, idade, raça, co-morbidades e até características genéticas, que tendem também a se distribuir aleatoriamente quando os pacientes designados para cada grupo são sorteados, sem nenhuma interferência médica ou dos coordenadores do estudo.

\section{RANDOMIZAÇÃO}

Caso a intenção de certo estudo é analisar apenas os efeitos da intervenção terapêutica proposta, fica clara a dedução da importância de se tentar eliminar quaisquer outros efeitos sobre o resultado. Numa analogia, mesmo remota, com o exemplo já citado envolvendo pacientes com doença linfoproliferativa, é bastante razoável rechaçar um estudo comparando-se dois diferentes anti-hipertensivos em que um dos grupos é composto, na maioria, por pacientes anglo-saxões com hipertensão em estágio 1 , com outro em que se concentram pacientes negros portadores de hipertensão não só em estágio mais avançado, como também de difícil controle.

Para se excluírem ao máxim fatores que influenciariam nos resultados da análise de uma intervenção terapêutica, o ideal é alocar os pacientes ao acaso, de tal forma que um paciente A seja designado para esta ou aquela intervenção porque a moeda jogada para ele caiu exibindo a face da coroa, e que os pacientes B, C, e assim por diante, também tenham sua "sorte" ditada pelo acaso. Como não se jogam moedas para as alocações dos pacientes dos estudos experimentais, um exemplo hipotético é demonstrado por uma tabela composta por números que representam os pacientes incluídos no estudo.

Um paciente é alocado ao acaso para intervenções diferentes (por exemplo, cirurgia $x$ tratamento clínico, droga $x$ placebo, 
quimioterapia $\mathrm{x}$ radioterapia) quando seu número é escolhido pelo cruzamento de um número da linha com um número da coluna. Tais cruzamentos são feitos de modo aleatório, por exemplo, fechando-se os olhos e apontando uma interseção linha x coluna qualquer. Para o segundo paciente em diante, nesse caso, poder-se-ia convencionar que o paciente seguinte será o próximo à direita ou à esquerda ou, ainda, abaixo ou acima, e assim sucessivamente.

TABELA 10.2 - Números aleatórios (randômicos) escolhidos cruzando-se linhas e colunas

\begin{tabular}{llllllllllllll}
\hline & $\mathbf{0 1 2 3 4}$ & $\mathbf{5 6} \mathbf{6} \mathbf{1 2 9}$ & $\mathbf{1 0}$ & $\mathbf{1 1}$ & $\mathbf{1 2}$ & $\mathbf{1 3}$ & $\mathbf{1 4}$ & \multicolumn{1}{c}{$\mathbf{1 5}$} & $\mathbf{1 6}$ & $\mathbf{1 7}$ & $\mathbf{1 8}$ & $\mathbf{1 9}$ \\
\hline $\mathbf{0 1}$ & $\mathbf{7} 8124$ & 23670 & 1 & 4 & 6 & 7 & 2 & 0 & 9 & 4 & 7 & 3 \\
$\mathbf{0 2}$ & 25734 & 23431 & 5 & 2 & 3 & 4 & 1 & 3 & 5 & 2 & 4 & 6 \\
$\mathbf{0 3}$ & 64562 & 72041 & 8 & 1 & 5 & 5 & 9 & 9 & 3 & 4 & 9 & 4 \\
$\mathbf{0 4}$ & 02151 & 32374 & 5 & $\underline{5}$ & 6 & 0 & 8 & 7 & 5 & 6 & 1 & 8 \\
$\mathbf{0 5}$ & 54371 & 63571 & 6 & 4 & 4 & 3 & 7 & 5 & 8 & 7 & 2 & 3 \\
\hline
\end{tabular}

Cruzando-se a linha número 4 com a coluna número 11 , tem-se o número 5 -ímpar. Esse paciente (linha 4, coluna 11) receberá o tratamento $A$, assim como todos os outros pacientes representados por um número ímpar, enquanto pacientes representados por um número par receberão o tratamento $B$.

Esse é um exemplo de várias formas equivalentes a se jogar uma moeda. É óbvio que há o risco de, ainda que sejam aleatórias as alocações, formarem-se dois (ou mais) grupos de tratamento com características diferentes um(uns) do(s) outro(s). Nesse caso, porém, em razão das probabilidades, isso se deve ao acaso - que pode proporcionar a exibição da mesma face de uma moeda jogada dez vezes, ou cem vezes, consecutivas, por exemplo. Todavia, tal risco é bastante reduzido pelo processo de randomização, que busca homogeneizar os grupos a serem comparados.

\section{RANDOMIZAÇÃo ESTRATIFICADA}

A distribuição randômica, ou aleatória, garante que as várias características relacionadas com os pacientes estejam distribuídas de modo uniforme entre os grupos comparados. Há certas situações, entretanto, em que os pesquisadores de um novo tratamento se preocupam com efeitos característicos de determinados grupos sobre os resultados do estudo. Em geral, trata-se de uma ou duas características que podem influenciar profundamente a resposta ao tratamento e, assim, comprometer a interpretação dos resultados obtidos.

Considere-se, mais uma vez, o exemplo do estudo tendencioso envolvendo pacientes portadores de hipertensão: a randomiza- 
ção, por si só, é capaz de alocar, com grande chance, pacientes brancos e negros, portadores de hipertensão estágio 1 e 2 de forma igual ou próxima da uniformidade entre os dois grupos tratados com diferentes anti-hipertensivos. Mas, embora seja capaz, ela não garante tal distribuição. O que podem fazer, nesse caso, os pesquisadores interessados em conduzir uma investigação extremamente imparcial? Podem, antes de submeter os pacientes ao tratamento, separá-los segundo a variável raça, considerando negros e brancos separadamente, e quanto ao estágio de hipertensão, ou seja, negros com estágio 1 ou 2 e brancos com estágio 1 ou 2. Após essa estratificação por raça e estágio de hipertensão arterial, faz-se à alocação aleatória, sabendo-se que contarão com número rigorosamente igual de pacientes com tais características distribuídos em cada grupo.

\section{ASPECTOS ESSENCIAIS EM ESTUDOS EXPERIMENTAIS}

\section{Amostragem}

Para restringir a heterogeneidade dos pacientes incluídos em um ensaio clínico, eles devem ser selecionados com base em critérios específicos de inclusão (presença da condição ou doença) e de exclusão (presença de outras doenças, doença atípica ou com prognóstico ruim, contra-indicações ao tratamento, recusa em participar do estudo, etc.). Dessa forma, há maior probabilidade de as diferenças observadas nos desfechos estarem relacionadas com o tratamento e, assim, melhorar a validade interna do estudo.

No entanto, muitos critérios de exclusão (vistos comumente em pacientes na prática clínica) possibilitam diminuir a capacidade de generalização dos resultados. Por conseqüência, pacientes em ensaios clínicos constituem amostra tendenciosa e altamente selecionada de todos os pacientes com a condição de interesse.

\section{Tratamento}

O tratamento em questão pode ser analisado segundo três aspectos: capacidade de generalização, complexidade e magnitude do efeito. A capacidade de generalização se relaciona com a implementação do tratamento comprovadamente eficaz na prática clínica usual, para que possa ser reproduzido em outras situações. A complexidade dos tratamentos utilizando, com freqüência, múltiplas alternativas terapêuticas, deve ser analisada com critério para que as intervenções possam ser aplicadas de modo reproduzível. A magnitude do efeito refere-se à avaliação dos desfechos esperados em relação às outras alternativas terapêuticas ou do grau de melho- 
ra clínica relacionada com um fator isolado ou dominante como causa de uma doença.

Ao final do estudo, informações sobre o tratamento que o paciente recebeu são essenciais. Isso porque são muitas as situações em que um paciente designado para receber um tratamento A não adere ao tratamento (ainda que pareça uma necessidade óbvia), caracterizando a chamada falta de adesão (compliance). Além disso, pode ocorrer de um paciente que, a princípio, concordou em participar da investigação, abandone o estudo. Uma outra situação é a de troca de medicações: o paciente passa a tomar o medicamento B por conta própria. Essas informações abrangem situações comprometedoras para a análise do ensaio experimental e devem sempre ser relatadas, para que os cálculos estatísticos as incluam nos números finais.

\section{Evolução}

Os critérios considerados como resposta ao tratamento devem ser estabelecidos de modo explícito pelo estudo, para se saber com exatidão o que é melhora; os efeitos colaterais devem igualmente ser estabelecidos e analisados ao final do estudo.

Dados como diminuição da pressão arterial sistólica de pelo menos $10 \%$ com uso de determinado anti-hipertensivo, redução de certa massa tumoral de $50 \%$ em um determinado período de tempo com o uso de novo quimioterápico e aumento da fração de ejeção ventricular utilizando-se nova classe de droga cardiotônica são alguns exemplos de resultados a serem analisados em estudos experimentais diversos. Deve-se garantir sempre que tais aferições sejam feitas com o mesmo rigor nos dois grupos de estudo.

\section{Mascaramento (Blinding)}

A fim de evitar interferências subjetivas em um estudo experimental, o ideal é que nem o paciente nem o médico saibam quem está tomando o medicamento (estudo duplo-cego). Isso para que, no caso do paciente, questões psicológicas não o influenciem a tentar saber se está tomando o medicamento ou placebo e, assim, se sentir mais ou menos motivado a até abandonar o estudo por achar que, ao tomar placebo, não há razão para ele se manter em algo que não lhe trará benefícios. No caso do médico, o mascaramento evita a situação "tentadora" de alterar a ordem do sorteio para direcionar o comprimido contendo o medicamento a um paciente que, na opinião dele, não poderia ficar sem o tratamento.

Em resumo, o mascaramento pode ser realizado em quatro níveis: 
1) alocação — os pesquisadores não devem saber em quais grupos de tratamento os pacientes serão alocados para não interferirem na distribuição aleatória;

2) pacientes - não devem saber que tipo de tratamento estão recebendo para não interferirem na adesão ao tratamento;

3) médicos - não devem saber que tratamento cada paciente recebeu para não interferirem no atendimento aos pacientes;

4) avaliação - os pesquisadores que avaliam os desfechos clínicos e/ou laboratoriais não podem conhecer os grupos de tratamento para não interferirem nas aferições.

Nem sempre o mascaramento é possível, sobretudo em algumas situações clínicas específicas (por exemplo, depressão medular com quimioterapia) nas quais os efeitos observados podem dar uma pista sobre o grupo de tratamento utilizado.

\section{ERros nas conclusões DE ESTUdos EXPERIMENTAIS}

Um indivíduo com determinado exame positivo pode não ter aquela doença, assim como existe a probabilidade de um paciente doente apresentar exame negativo, como já foi comentado no capítulo 8. Igualmente, os resultados de um estudo terapêutico experimental - ainda que seja randomizado (talvez até estratificado), controlado, duplo-cego - podem não refletir as reais conclusões que deveriam ser extraídas.

Quando, na introdução desta seção, foram destacados os atributos essenciais de um estudo para que possa produzir resultados confiáveis, na realidade, foram citados os passos a serem seguidos no planejamento e na execução de um estudo experimental (experimento clínico, ensaio clínico ou clinical trial). Tais passos são essenciais para evitar, a qualquer custo, que determinado ensaio clínico contenha um ou vários "furos".

Os furos podem ocorrer por qualquer viés (bias) — ou seja, tendenciosidade, sobretudo subjetiva - em algum ponto do estudo; por exemplo, pode ocorrer um viés na alocação de um grupo-controle - sem um emparelhamento homogêneo; no tamanho da amostra - insuficiente para produzir resultados com poder estatístico, ou ainda, como já foi citado, na alocação tendenciosa do tratamento pelo médico. Esses fatores, dentre outros, podem afetar os dados finais retirados do estudo para a análise estatística.

Provoca-se um erro de amostragem, por exemplo, quando pacientes negros e brancos não são distribuídos nas mesmas proporções em dois grupos utilizados para comparação de regimes 
anti-hipertensivos distintos. Se houver menos rigor - como na simples técnica de aferição da pressão arterial em um dos grupos -, tende-se ao erro de aferição. Ambas as incorreções constituem o chamado vício de um estudo, que, ao lado do acaso, atua na produção dos referidos furos.

O acaso é um erro inerente a qualquer estudo, por mais bem planejado, conduzido e calculado que seja este. Ainda que se calcule o número adequado de pacientes (tamanho da amostra) a serem seguidos, com critérios de inclusão bem definidos, desfechos criteriosos, imparcialidade na execução do tratamento de grupos homogêneos, e se faça análise estatística com modelos corretamente aplicados, existirá sempre a chance de aquela diferença (ou diferenças) ter ocorrido ao acaso ou mesmo não se ter chegado à conclusão de que o tratamento é benéfico, quando na realidade o é. Como foi visto nos capítulos 5 e 6 , esses dois tipos de erros atribuídos ao acaso são os chamados de erro tipo I e erro tipo II - como demonstra o Quadro 10.1.

\begin{tabular}{|ccc|}
\hline $\begin{array}{c}\text { Conclusão } \\
\text { do } \\
\text { Estudo }\end{array}$ & \multicolumn{2}{c|}{ Conclusão que deveria ser tirada } \\
\cline { 2 - 3 } & não são diferentes & $\begin{array}{c}\text { Tratamentos } \\
\text { são diferentes }\end{array}$ \\
\hline $\begin{array}{c}\text { Tratamentos } \\
\text { não são } \\
\text { diferentes }\end{array}$ & Decisão correta & $\begin{array}{c}\text { Erro tipo II } \\
\text { (erro } \boldsymbol{\beta} \text { ) }\end{array}$ \\
$\begin{array}{c}\text { Tratamentos } \\
\text { são diferentes }\end{array}$ & $\begin{array}{c}\text { Erro tipo I } \\
(\text { erro } \boldsymbol{\alpha})\end{array}$ & Decisão correta \\
\hline
\end{tabular}

QUADRo 10.1 - Relação entre conclusões alcançadas e conclusões que deveriam ter sido tiradas em um estudo terapêutico experimental

Se um medicamento que nunca produziu efeito de reversão de uma arritmia em estudos anteriores agora traz resultados fantásticos em novo estudo experimental, há de se pensar na possibilidade de ter ocorrido um erro tipo I, ou seja, apesar dos resultados benéficos demonstrados, ele pode não ter produzido tal efeito de fato.

Essa probabilidade de o medicamento em questão ter sido superior ao tratamento convencional é, em geral, expressa nos trabalhos através do valor de $P$. Se este trabalho fornece uma evidência de que a droga testada reverte certa arritmia em porcentagem superior à droga convencional com um $P<0,05$, então ele expressa uma chance inferior a $5 \%$ de a diferença ter ocorrido ao acaso. Tal chance poderia ser, por exemplo, menor que $1 \%$ caso o pesquisador quisesse ser mais rigoroso ao pensar em eliminar a chance de erro tipo I.

No entanto, caso ele fosse muito rigoroso, incorreria no risco de não conseguir mostrar um benefício que realmente existe. Com 
isso, aumentaria a probabilidade de erro tipo II (erro $\beta$ ). Uma boa opção, nesse caso, é o aumento do tamanho da amostra, a fim de diminuir a chance da ocorrência do acaso (lembrar a razão de probabilidades referida para a moeda jogada), ao mesmo tempo em que testaria a droga em um maior número de indivíduos com resultados potencialmente favoráveis. Quanto menor for a probabilidade de erro tipo II, maior será o poder do estudo.

\section{Questões Éticas}

Estudos terapêuticos experimentais, muitas vezes, colocam os pesquisadores responsáveis em situações injustas - por exemplo: não proporcionar tratamento cirúrgico ou quimioterápico a pacientes oncológicos para efeito de comparação entre grupos, assim como não oferecer o coquetel anti-retroviral a pacientes aidéticos. Além de injustas, essas situações são consideradas antiéticas e, em geral, não têm aprovação do Comitê de Ética em Pesquisa (CEP), que julga os aspectos de um estudo experimental e autoriza o início em determinada instituição (ver capítulo 3 ).

Da mesma forma, se há evidências de que certo medicamento em investigação acarreta maior comprometimento funcional ou mais mortes que o tratamento convencional comparado, o Centro Coordenador da Pesquisa, via de regra, opta pela interrupção do estudo, ainda que este não tenha sido concluído. Além disso, é muito comum que os resultados nem venham a ser publicados na literatura.

Por outro lado, havendo evidência estatística de benefício superior da droga ou intervenção, mesmo com o estudo ainda em curso, a regra é interromper o ensaio e tomar tal tratamento como novo padrão a partir dali.

Nunca é demais lembrar que a ética em pesquisa, também, se aplica à imparcialidade no que se refere às pessoas envolvidas no estudo e que podem distorcer os resultados quando interferem no tão falado e importante processo de randomização.

\section{CONCLUSÃO}

Os diferentes tipos de estudos têm ou não capacidade de demonstrar a eficácia de uma nova intervenção relativamente à não-intervenção ou ao tratamento adotado até então. Pelo que se tentou demonstrar - ao delinearem seus passos e discutirem sua validade, os estudos experimentais ou ensaios clínicos randomizados são mais apropriados para se avaliar essa questão. 
Os erros tipo I e tipo II podem ocorrer mesmo que se randomizem apropriadamente os grupos a serem estudados, seja por obra do acaso ou por fatores como amostra muito pequena.

Independentemente dos interesses pessoais ou financeiros envolvidos, a ética sempre deve prevalecer para que o objetivo a ser alcançado ao final de qualquer experimento clínico, seja a busca da cura ou, no mínimo, da melhora da qualidade de vida do paciente.

\section{REFERÊNCIAS}

FLETCHER, R. H.; FLETCHER, S. W.; WAGNER, E. H. Epidemiologia clínica: elementos essenciais. 3. ed. Porto Alegre: Artes Médicas, 1996. 281p.

GORDIS, L. Epidemiology. Philadelphia: W. B. Saunders, 1996. JORGE, M. T.; RIBEIRO, L. A. Fundamentos para o conhecimento científico: áreas de saúde. São Paulo: CLR Balieiro, 1999.

KORBET, S. M. et al. Factors predictive of outcome in severe lupus nephritis. American Journal of Kidney Diseases, Minneapolis, v. 35, n. 5, p. 904-914, 2000.

ZAGO, M. A.; FALCÃO, R. P.; PASQUINI, R. Hematologia: fundamentos e prática. São Paulo: Atheneu, 2001. 


\section{ÍNDICE REMISSIVO}


A

\section{Acrobat Reader, 38}

Acurácia

índice de validade, 211

programas computacionais, 217

Agradecimentos, estrutura de trabalho científico, 41

Agrícola

bases de dados internacionais, 36

AIDS

epidemiologia, 119

estudos sobre causalidade, 184

estudos sobre diagnóstico, 216

pandemia, 124

pesquisa em seres humanos, 59

prognóstico, 234

vírus da imunodeficiência humana, 184

Amostra, 138

Amostragem

formas de, 140

estudos experimentais, 250

Amostragem aleatória ou randomizada, 140

Amostragem estratificada, 141

Amostragem sistemática, 141

Anais de eventos científicos

fontes primárias, 34

Análise de sobrevida, 235

Análise de variância (ANOVA), 161

Análise de variância de KruskalWallis, 175

Análises de associação, 163

Analogia

relação entre causa e efeito, 187
Anexos

apêndices/anexos, 29

estrutura do documento, 23

Antagonismo, 184

Anticorpos específicos

detecção, 215

Apêndice

apêndices/anexos, 29

estrutura do documento, 23

Áreas do conhecimento, 30

Artigos de periódicos

fontes primárias, 34

Artigos de revista exemplos de referências bibliográficas, 47

Associação

medidas de, 188

Associação Brasileira de Normas

Técnicas

estrutura de trabalho científico, 29, 40

Associação causal, 186

Autonomia

resolução 196/96, 61

Avanços e progressos

fontes secundárias, 34

B

Barreiras primárias, 83

Barreiras secundárias, 84

Bases de dados

automatizadas, 35

em ciências da saúde, 35

fontes secundárias, 34

Bases de dados internacionais, 36

Bases de dados nacionais, 35 


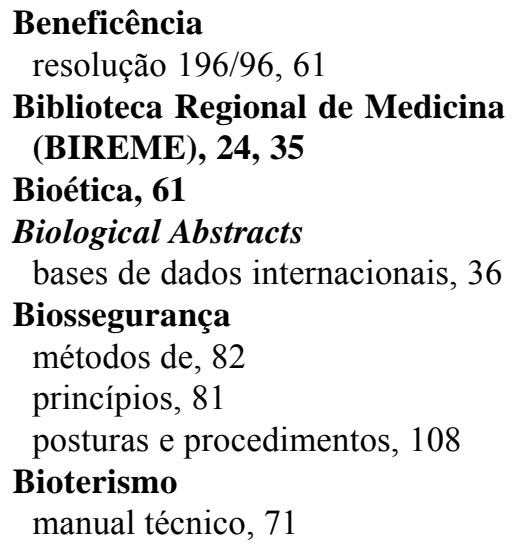

BIREME (Biblioteca Regional de Medicina), 24, 35

Blinding mascaramento, 25

C

\section{Cab Abstracts} dados internacionais, 36

Cabines de segurança biológica, 83

Caixa de primeiros socorros, 109

Capa estrutura do documento, 40

Capítulo de livro com autoria própria, 47 sem autoria própria, 46

Caso-controle estudos, 128

Causa, 183

Causa necessária, 184

Causa suficiente, 184

Charles Darwin pesquisa em animais, 68

Ciências biológicas, 30

Ciências da saúde, 30

Ciências sociais aplicadas, 30

Citações citação de citação, 45 citações no texto, 44 citação direta, 44

citação indireta, 44

CNPq áreas do conhecimento, 30 base de dados nacionais, 35 portal do CNPq, 35

Código de ética médica, 65

Código de Nuremberg, 60

Coeficiente de correlação de Pearson, 168

Coeficiente de variação, 146

Coeficiente ou índice de associação de Yule (Q), 165

Comissão Nacional de Ética em Pesquisa, 63

Comissões de Ética em Experimentação Animal, 70

Comitê de Ética em Pesquisa, 63

Complexidade, 59

Compliance, 251

Comutação bibliográfica, 38, 251

Conclusões estrutura do documento, 43

Confiança do teste laboratorial, 210

Conselho Federal de Medicina, 65 Conselho Nacional de Saúde, 61

Consentimento livre e esclarecido resolução 196/96, 62

Consistência, 187

Constituição Federal, 20

Contenção primária, 82

Contenção secundária, 83

Coorte histórica, 243

Coorte contemporânea, 247

Correlação negativa, 166, 167 positiva, 166, 167

Correlação de Rank, 169

Cronograma financeiro, 28

Cronograma físico, 27

CSB classe I (cabine de segurança biológica classe I), 98 


\section{Doença}

história natural, 225

Drogas anestésicas

eutanásia, 74

E

Efeito Hawthorne, 244

Efeitos colaterais, 241, 251

Efetividade, 241

Eficácia, 241

Elementos pós-textuais estrutura do documento, 43

Elementos pré-textuais estrutura do documento, 40

Elementos textuais estrutura do documento, 42

\section{ELISA}

curva ROC, 217, 218

sensibilidade e especificidade, 218

Enciclopédias, 34

Epidemia

definição, 122

epidemias explosivas, 123

epidemias lentas, 123

fatores relacionados ao agente, 123

fatores relacionados ao ambiente, 123

fatores relacionados ao hospedeiro, 123

fluxograma do método de estudo, 122

fonte persistente, 123

fonte pontual, 123

Epidemiologia conceitos e métodos, 115 processo saúde-doença, 116

Epígrafe estrutura do documento, 41

Equipamentos de contenção nível de segurança 1,87 nível de segurança 2, 90 nível de segurança 3, 93 nível de segurança 4, 96 
Equipamentos de proteção coletiva, 109

Equipamentos de proteção individual, 109

Equipamentos de segurança barreiras primárias, 83

Erro $\alpha, 131$

Erro $\beta, 131$

Erro de aferição, 253

Erro de amostragem, 131, 252

Erro padrão da média,, 147

Erro randômico, 131

Erro sistemático (vício), 132

Erro tipo 1 ou $\alpha, 131$

Erro tipo 2 ou $\beta, 131$

Erros potenciais em estudos epidemiológicos, 131

Especificidade

curva TG-ROC, 216

definição, 203

índice de Youden, 210

interpretação, 205

ponto de corte (cut off), 215

razão de probabilidades, 213

tabela ce contingência, 205

valor preditivo e, 207

Estado funcional do paciente

prognóstico, 227

Estatística

conceitos básicos, 137

objetivo de estudo, 137

Estatística inferencial, 138

Estatística Z, 156

Estudo experimental, 126, 246

Estudo observacional analítico

caso-controles, 128

coortes, 128

ecológicos, 128

seccionais, 128

Estudo observacional descritivo

relato de casos, 127

série de casos, 127

Estudos caso-controle, 128

Estudos comparativos, 243

Estudos controlados, 130
Estudos de campo, 130

Estudos de comunidade, 130

Estudos do tipo coortes, 128, 130

Estudos ecológicos, 128

Estudos epidemiológicos

erros potenciais, 131

tipos de, 126

Estudos experimentais, 130

erros nas conclusões, 252

estudos controlados, 130

estudos de campo, 130

estudos de comunidade, 130

Estudos intervencionais, 130

Estudos não comparativos, 243

Estudos observacionais, 243

Estudos seccionais, 128

Etapas do projeto de pesquisa, 22, 27

Ética, 30, 59

Eutanásia

animal, 70, 73, 74

métodos físicos, 74

métodos químicos, 74

Evolução

história natural da doença, 226

Exatidão, 134

Experimento binomial, 148

Experimentos

categorias, 73

Experimentos condenáveis, 74

Explicitação do tema

projeto de pesquisa, 22, 24

$\mathbf{F}$

Falsos negativos, 205

Falsos positivos, 205

Falta de adesão, 251

Fator de confundimento ou fator de confusão, 133

Fatores agravantes, 186

Fatores de risco genéticos, 186

físicos, 186 
químicos, 186

biológicos, 186

sociais, 186

comportamentais, 186

Fatores desencadeantes, 186

Fatores facilitadores, 186

Fatores predisponentes, 186

Fatores prognósticos, 226, 236

Ficha catalográfica, 41

Fichamento, 39

Folha de aprovação da banca examinadora

estrutura do documento, 41

Folha de rosto

estrutura do documento, 40

Fontes de informação, 33

Fontes primárias, 33

Fontes secundárias, 34

Força da associação, 187, 198

Formaldeído, 133

Formatação da apresentação, 48

Formulação do problema de estudo, 22, 25

Formulários, 23

Friedman

dupla análise de variância, 177

G

Galen e Gambino, 204

Gases

biossegurança, 84, 95

Genoma

patente, 28

Germoplasma

patente, 28

Glossário

estrutura do documento, 43

Gold standard

padrão ouro, 204

Gráfico de dispersão

correlação, 167

curva ROC, 217
Grupos de comparação

terapêutica, 244

\section{H}

Hanseníase, 123

Hipótese experimental ou alternativa $\left(\mathrm{H}_{1}\right), 26,152,153$

Hipótese nula, 26, 152, 153

Hipóteses de trabalho, 26

Histograma, 148

HIV

biossegurança, 88

estudos sobre causalidade, 184

estudos sobre diagnóstico, 208

estudos sobre prognóstico, 227

I

Identificação

projeto de pesquisa, 21

IFAT

curva ROC, 218

curva TG-ROC, 220

Incidência

cálculo, 122

coeficiente de, 189

medidas de morbidade, 119

Incidência e prevalência

comparações, 121

Índice (Index), 31

Índice de validade acurácia, 211

Índice de Youden

cálculo, 210

programas computacionais, 217

Índices

estrutura de trabalho científico, 44

Infotrac Custom Journals

dados internacionais, 36

Inquéritos

epidemiológicos, 126 
Instalações

projeto e construção, 82

Instalações laboratoriais

nível de segurança 1,87

nível de segurança 2, 91

nível de segurança 3, 93

nível de segurança 4, 96

Intensidade, 121, 187, 188

Interação entre causas múltiplas antagonismo, 184

sinergia, 184

Interdependência entre duas variáveis, 163

Intervalo de confiança

definição, 159

média populacional, 159

para proporção ou probabilidade, 160

valores de $t$ de student, 139

Intoxicação alimentar, 123

Introdução

estrutura do documento, 22

projeto de pesquisa, 24

Invenção patenteável, 28

J

Janela imunológica, 215

Journal@Ovid

dados internacionais, 36

Justiça

resolução 196/96, 61

Justificativas

estrutura do documento, 22

projeto de pesquisa, 26

\section{$\mathbf{K}$}

\section{Kaplan-Meir}

análise de sobrevida, 235

Kappa, 211

interpretação, 213

programas computacionais, 217
Koch

postulados de, 183

Kruskal-Wallis

análise de variância, 175

L

Leishmaniose canina visceral áreas endêmicas, 125

Leitura técnica, 39

Letalidade

epidemiologia, 119

prognóstico, 227

Likelihood ratios

(razão de probabilidades), 213

Linha de pesquisa, 31

Lista de abreviaturas e siglas

estrutura do documento, 42

Lista de ilustrações

estrutura do documento, 42

Lista de símbolos

estrutura do documento, 42

Lista de tabelas

estrutura do documento, 42

M

Manipulação genética, 76, 82

Mantel-Haenszel Weighted risco relativo ajustado, 198

Manuais

fontes secundárias, 34

Mascaramento

níveis, 251

Materiais biológicos

patente, 28

Material de consumo

cronograma financeiro, 28

Material e métodos

estrutura do documento, 42

Material permanente

cronograma financeiro, 28 
Média aritmética, 142

Mediana, 143

Medidas de associação, 188

Medidas de morbidade

proporção de fatalidade, 119

taxa de incidência, 119

taxa de prevalência, 119

Medidas de mortalidade

taxa de mortalidade total, 117

taxa de mortalidade específica, 117

taxa de mortalidade infantil, 117

razão de mortalidade proporcional,

117

Medidas de tendência central, 142

Método científico, 18, 19, 20

Metodologia

projeto de pesquisa, 18, 22, 23

Métodos físicos

eutanásia, 74

Métodos químicos

eutanásia, 74

Ministério da Saúde, 30, 37, 61

Moda, 142, 143

Monografias

fontes primárias, 33

Morbidade, 117

Mortalidade, 117

\section{$\mathbf{N}$}

Não-maleficência

resolução 196/96, 61

Níveis de biossegurança, 85

instalações, 84

Níveis de biossegurança animal

doenças transmitidas, 105

Nível de biossegurança

nível de biossegurança 1 (NB-1), 86

nível de biossegurança 2 (NB-2), 87

nível de biossegurança 3 (NB-3), 91

nível de biossegurança 4 (NB-4), 94

Normas técnicas

ABNT, 29, 40

Notas de rodapé, 45
$\mathbf{O}$

Objetivos

projeto de pesquisa, 22, 26

Observações, 138, 166

Odds ratio, 190

Operadores boleanos, 37

Organização Mundial da Saúde, 37

$\mathbf{P}$

Padrão ouro

gold standard, 204

Palavras-chave

projeto de pesquisa, 22, 23

Pandemia

definição, 122

Pesquisa

em animais, 68

em seres humanos, 59

ética médica, 65

Pesquisa aplicada, 20, 26

Pesquisa básica, 20, 26

Pesquisa bibliográfica, 23, 33

Pesquisa científica, princípios da pesquisa com animais, 69

reprodutibilidade, 19

Pesquisa médica

objeto principal da, 64

relacionada à ética médica, 66

Pesquisa na área da saúde, 37

Placebo

aspectos éticos, 61

estudo experimental, 127

mascaramento (blinding), 251

randomização, 248

tratamento, 244

Plano de trabalho

projeto de pesquisa, 22

Plausibilidade biológica, 187, 200

Poder do teste, 131

Polígono de freqüências, 148 
Ponto de corte

cut off, 207, 215

População, 138

Portal CAPES, 36, 38

Prática e técnica laboratorial biossegurança, 82

Práticas laboratoriais especiais nível de segurança 1,87 nível de segurança 2,89 nível de segurança 3, 92 nível de segurança 4, 95

Precisão, 134

Prevalência definição, 119 taxa de, 119

Princípio dos três "Rs", 68

Processos biológicos naturais patente, 28

Prognóstico definição, 225

expressando, 227

tabela de medidas de, 228

Projeto de pesquisa científica estrutura simplificada, 29

estrutura típica, 20

na área biológica, 23

Projeto de pesquisa para a área biomédica informações da estrutura, 21

Proporção de Fatalidade ou Letalidade, 119

Proporção de Mortalidade Neonatal, 118

Proporção de Mortalidade Perinatal, 118

Propriedade industrial lei, 28

Propriedades da informação projeto de pesquisa, 23

Proteção pessoal biossegurança, 82

Prova de Friedman dupla análise de variância, 177

Psycinfo dados internacionais, 36

\author{
Publicidade \\ ética médica, 67 \\ PUBMED
}

bases de dados internacionais, 36

\section{Q}

Qualidade de vida

vida animal, 105

prognóstico, 225

Questionários vazios

anexos/apêndice, 29

Questões éticas

relativas à pesquisa em seres humanos, 65

terapêutica, 254

$\mathbf{R}$

Raciocínio indutivo, 19

Randomização, 248

estratificada, 249

Rastreamento

testes de, 215

Razão de chances, 190

Razão de Mortalidade Fetal, 118

Razão de Mortalidade Materna, 118

Razão de Mortalidade Proporcional, 117, 118

Razão de probabilidades, 213

Recursos materiais e financeiros projeto de pesquisa, 27

Redação do texto, 44

Rede de causalidade, 184

Reduce princípio dos três "Rs", 68

Referencial teórico projeto de pesquisa, 25

Referências bibliográficas estrutura do documento, 29 projeto de pesquisa, 23

\section{Refine} princípio dos três "Rs", 68 
Regressão, 163, 166, 171

Relação com pacientes e familiares ética médica, 66

Relação dose-resposta, 187

Relação entre causa e efeito, 183, 187

Relação temporal, 187, 188

Relato de caso

estudo observacional descritivo, 243

Relatórios técnicos

fontes primárias, 33

Replace

princípio dos três "Rs", 68

Reprodutibilidade

relação entre causa e efeito, 187

Resolução $N^{\circ}$ 196/96, 61

Resolução $N^{\circ}$ 251/97, 65

Resultados

estrutura do documento, 43

Resumo

projeto de pesquisa, 22

Resumo na língua estrangeira estrutura do documento, 41

Resumo na língua vernácula estrutura do documento, 41

Reversibilidade

relação entre causa e efeito, 187

Revisão bibliográfica

projeto de pesquisa, 22

Revisão da literatura

estrutura do documento, 42

Risco atribuível, 189

Risco relativo, 189

Riscos e benefícios, 22

resolução 196/96, 62

Roteiros de entrevistas

anexos/apêndice, 29 terapêutica, 241

Secretaria do Tesouro Nacional, 28

Segurança

de vacinas e de medicamentos, 126

Sensibilidade

cruva TG-ROC, 216

definição, 203

índice de Youden, 210

interpretação, 205

ponto de corte (cut off), 215

tabela de contingência, 204

valor preditivo e, 207

programas computacionais, 217

razão de probabilidades (likelihood

ratios), 213

Seres vivos naturais

patente, 28

Série de casos

estudo observaconal descritivo, 127

Serviços de terceiros

cronograma financeiro, 28

Significância estatística

erros randômicos, 131

Sinergia, 184

Sinalização, 110

Sistema autor-data

citações no texto, 45

Sistema numérico

citações no texto, 45

Slope

cruva ROC, 217

Sobrevida

prognóstico, 225, 227

Sobrevida em 5 anos

prognóstico, 228, 229

Sobrevida observada

prognóstico, 228, 229, 230

Subjetividade

ética, 59

Sumário

estrutura de trabalho científico, 24

projeto de pesquisa, 22

Surto epidêmico

definição, 124
Screening

diagnóstico, 215

prognóstico, 229 
$\mathbf{T}$

Tabagismo, 132, 184, 185

Tabela de contingência

exemplos, 164, 165, 205, 208, 209

Tabelas

lista de, 42

Tamanho amostral

cálculo, 139

estimativa de proporções, 139

Taxa de Incidência

cálculo, 122

medidas de morbidade, 119

Taxa de Mortalidade Específica, 117

Taxa de Mortalidade Infantil, 117

Taxa de Mortalidade Total, 117

Taxa de Prevalência

cálculo, 120

medidas de morbidade, 119

Taxas de Mortalidade

método direto, 118

método indireto, 118

Tempo zero, 226, 228

Temporalidade ou relação temporal relação entre causa e efeito, 187

Tendenciosidade

terapêutica, 252

Teorema do limite central, 147

Tese de Estudo

projeto de pesquisa, 26

Teses

exemplos de referências bibliográficas, 47

fontes primárias, 33

pesquisa bibliográfica, 34

Teste de Bernoulli, 148

Teste de correlação de Pearson, 169

Teste de correlação de Spearman, 169

Teste de McNemar, 162, 179

Teste de Wilcoxon, 173

Teste diagnóstico

interpretação clínica, 204

interpretação laboratorial, 205
Teste do qui-quadrado, 164

Teste do sinal, 162

Teste estatístico

poder, 155

Teste exato de Fisher, 171

Teste laboratorial medidas da eficiência, 210

Teste $\boldsymbol{t}$ de Student amostras não pareadas, 158 amostras pareadas, 158

Teste U de Mann-Whitney, 162

Testes de hipóteses, 132, 154

Testes de triagem, 215

Título

projeto de pesquisa, 21

sorológico, 218, 219

Toxoplasmose

animais e respectivas doenças po-

tenciais, 106

canina, 168,169

congênita, 216

curva ROC, 218, 219

disseminação de doenças, 107 ok

Trabalhos apresentados em even-

tos, 34

exemplos de referências bibliográ-

ficas, 46

Transgênicos

ética animal, 76

patente, 28

Triagem sorológica, 216

Truncamento

operadores boleanos, 37

$\mathbf{U}$

UNESCO,

Declaração Universal dos Direitos dos Animais, 70

Unimodal, 150

Unitermos

projeto de pesquisa, 22, 23

Universidade de São Paulo

site de pesquisa, 37 
Validação de um procedimento laboratorial, 206

Valor preditivo, 206

Valor preditivo negativo, 206

Valor preditivo positivo, 206

Variação biológica individual erro randômico, 131

erro sistemático, 132

Variância, 144, 145

Variáveis

tipos de, 141

Variáveis de confundimento, 194

Variáveis de confundimento e modificadoras de efeito, 197

Variáveis contínuas, 141, 215, 217

Variáveis descontínuas, 142

Variáveis interferentes

controle das, 194
Variáveis modificadoras de efeito,

194, 195

Variáveis qualitativas, 141, 142

Variáveis quantitativas, 141, 144

Verdadeiros negativos, 204, 205

Verdadeiros positivos, 204, 205

Viés, 186, 187, 194

Vírus da imunodeficiência humana

(HIV), 184

Voluntários

ética médica, 66

$\mathbf{X}$

Xenotransplantação

ética animal, 75 
SOBRE OS AUTORES 


\author{
José Roberto Mineo \\ Biomédico (Escola Paulista de Medicina-UNIFESP) \\ Doutor em Microbiologia e Imunologia (ICB-USP) \\ Pós-Doutorado (Faculdade de Medicina de Ribeirão Preto-USP) \\ Visiting Professor of Medicine \\ (Darmouth Medical School-NH-USA)
}

Deise Aparecida de Oliveira Silva

Médica Veterinária

Universidade Estadual Paulista Júlio de Mesquita Filho

(UNESP-Botucatu)

Pesquisadora do Laboratório de Imunologia,

Universidade Federal de Uberlândia.

Doutoranda em Imunologia e Parasitologia Aplicadas, Instituto de Ciências Biomédicas da

Universidade Federal de Uberlândia.

Mônica Camargo Sopelete

Médica Veterinária

Universidade Estadual Paulista Júlio de Mesquita Filho

(UNESP-Jaboticabal)

Doutora em Imunologia e Parasitologia Aplicadas

Instituto de Ciências Biomédicas da

Universidade Federal de Uberlândia

\title{
Geraldo Sadoyama Leal
}

Biólogo (Universidade Federal de Uberlândia)

Doutor em Imunologia e Parasitologia Aplicadas Instituto de Ciências Biomédicas da Universidade Federal de Uberlândia

\section{Luiz Henrique Guerreiro Vidigal}

Médico (Universidade Federal de Uberlândia)

Departamento de Clínica Médica, Faculdade de Medicina

Intituto de Ciências Biomédicas da

Universidade Federal de Uberlândia

\author{
Luis Ernesto Rodriguez Tápia \\ Doutor em Psicologia Clínica (PUC-SP) \\ Pós-Doutorado em Psiquiatria (FMRP-USP) \\ Professor Titular do Departamento de Clínica Médica \\ (FAMED-UFU)
}

\author{
Maria Inês Bacchin \\ Bacharel em Biblioteconomia \\ (Escola de Sociologia e Política de São Paulo) \\ Gerente da Biblioteca Campus Santa Mônica \\ (Sistema de Bibliotecas da Universidade Federal de Uberlândia)
}


Imprensa Universitária/Gráfica UFU 
A idéia de escrevermos este livro surgiu a partir das discussões fomentadas durante as disciplinas ministradas em Programas de Pós-Graduação onde estamos envolvidos, fruto da interação entre docentes e discentes. Verificamos que a falta de uma discussão de forma sistemática das etapas que compreendem o método científico representam um obstáculo para aqueles que se propõem a trabalhar com pesquisa na área biomédica.

Um dos principais argumentos dos defensores dos programas de pós-graduação stricto sensu nesta área do conhecimento é a inovação tecnológica. Estes programas criam o ambiente propício para se desenvolver as atividades de pesquisa que impulsionam a indústria biotecnológica, obrigando o profissional a estar sempre sintonizado com as pesquisas de ponta, para que ele possa desempenhar com eficiência suas atividades profissionais.

Os principais nichos de trabalho e pesquisa em tecnologia na área biomédica nas próximas décadas exigirão um envolvimento cada vez mais freqüente com o método científico. Estes nichos estarão centrados nas trajetórias cientificotecnológicas da biomedicina contemporânea, como a genética genômica, a análise proteômica, a biologia celular de células-tronco e a tecnologia de imagem molecular. Por sua vez, este envolvimento diminuirá cada vez mais o tempo a ser transcorrido entre a obtenção de resultados consistentes e relevantes, frutos dos projetos de pesquisa, e sua aplicação no bem estar dos habitantes deste planeta.

A consequência imediata do rápido progresso que se verifica na pesquisa biomédica é que esta área saiu do estágio em que, por exemplo, as terapias passaram de uma fase empírica para a fase em que os tratamentos são preferencialmente baseados no entendimento dos mecanismos das doenças e de como preveni-las. Assim, é fundamental haver uma familiarização contínua destes profissionais com as etapas que envolvem as aplicações do método cientifico, capacitando-os como geradores e aplicadores do conhecimento adquirido.

A nossa intenção é que os leitores deste livro possam estar em contato com as etapas necessárias para a aplicação do método científico na área biomédica, contribuindo para que estas sejam amplamente discutidas e colocadas em prática.

Os autores.

\section{Editora filiada à}

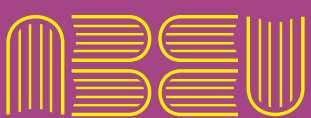

ASSOCIAÇÃO BRASILEIRA DAS EDITORAS UNIVERSITARIAS

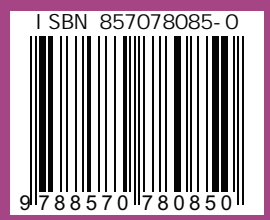

